\begin{abstract}
SZEGEDI TUDOMÁNYEGYETEM
BÖLCSÉSZETTUDOMÁNYI KAR

NEVELÉSTUDOMÁNYI DOKTORI ISKOLA

AZ OKTATÁS ÉS NEVELÉS PSZICHOLÓGIAI ÉS KOGNITÍV IDEGTUDOMÁNYI KÉRDÉSEI DOKTORI PROGRAM
\end{abstract}

GÁL ZITA

\title{
A TUDATELMÉLET ÉLETKORI KÜLÖNBSÉGEI, KAPCSOLATA A MUNKAMEMÓRIA KAPACITÁSSAL ÉS A TÁRSAS POZÍCIÓVAL
}

PhD-értekezés

Témavezető:

Dr. Németh Dezső

habilitált egyetemi docens

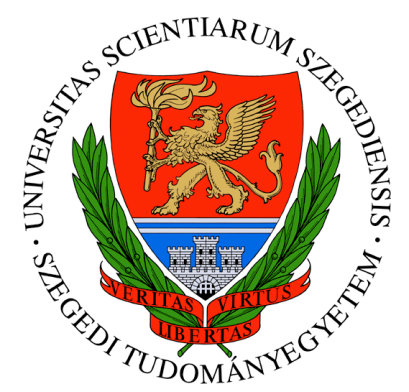




\section{TARTALOM}

BEVEZETÉS

1. A TUDATELMÉLET FOGALMÁNAK MEGHATÁROZÁSA, IDEGTUDOMÁNYI KÉRDÉSEI ......10

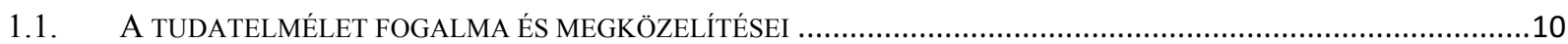

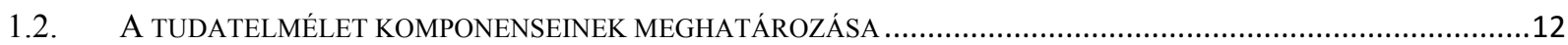

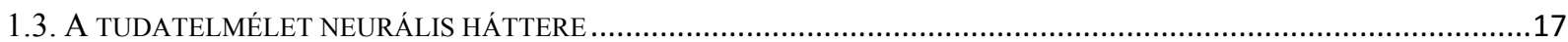

2. A TUDATELMÉLET MÉRÉSI LEHETŐSÉGEI ............................................................................23

3. A TUDATELMÉLET FEJLŐDÉSE, EGÉSZ ÉLETEN ÁT TARTÓ ÉLETKORI VÁLTOZÁSAI.......29

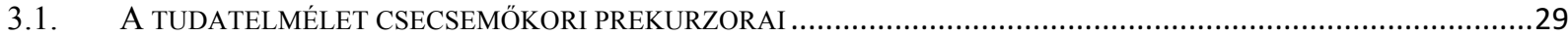

3.2. A TUDATELMÉLET GYERMEKKORI FEJLÖDÉSÉRE VONATKOZÓ ELKÉPZELÉSEK ……...................................30

3.3. A TUDATELMÉLET ÉLETKORI VÁLTOZÁSAI SERDÜLÖ- ÉS FELNŐTTKORBAN...............................................

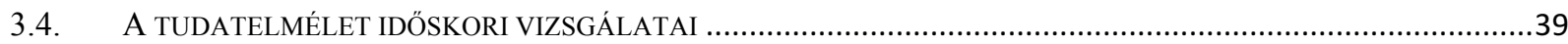

3.5. A TUDATELMÉLET FEJLŐDÉSÉVEL KAPCSOLATOS ELMÉLETI ALAPVETÉSEK ……….................................43

4. A TUDATELMÉLET FEJLŐDÉSÉBEN SZEREPET JÁTSZÓ KÖRNYEZETI TÉNYEZŐK .............48

5. A TUDATELMÉLET ÉS A KOGNITÍV FUNKCIÓK KAPCSOLATA ..............................................51

5.1. ELMÉLETI ALAPVETÉSEK A TUDATELMÉLET ÉS A KOGNITÍV FUNKCIÓK KAPCSOLATÁRÓL_...........................51

5.2. A VÉGREHAJTÓ FUNKCIÓK, A MUNKAMEMÓRIA ÉS A TUDATELMÉLET KÖZÖTTI KAPCSOLAT EMPIRIKUS

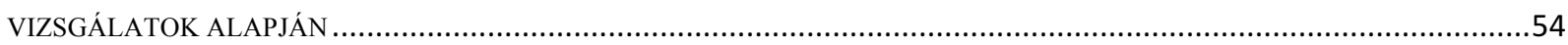

5.2.1. A tudatelmélet, a munkamemória és a végrehajtó funkciók kapcsolata gyermekkorban ..................54

5.2.2. A tudatelmélet, a munkamemória és a végrehajtó funkciók kapcsolata serdülö-, felnött-és

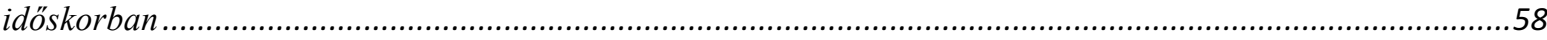

6. A TUDATELMÉLETI KÉPESSÉG ÉS A TÁRSAS VISELKEDÉS KAPCSOLATA ............................61

6.1. A TUDATELMÉLET ÉS A TÁRSAS VISELKEDÉS ÖSSZEFÜGGÉSEI ÓVODÁSKORÚ GYERMEKEKNÉL ..................62

6.2. A TUDATELMÉLET ÉS A TÁRSAS VISELKEDÉS ÖSSZEFÜGGÉSEI ISKOLÁSKORÚAKNÁL.................................65

6.3. A TUDATELMÉLET ÉS A TÁRSAS VISELKEDÉS ELLENTMONDÁSA: A BULLYING ..........................................67

7. AZ EMPIRIKUS VIZSGÁLAT CÉLJAI, HIPOTÉZISEI ....................................................................69

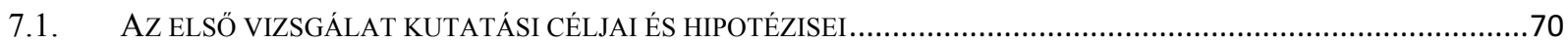

7.2. A MÁSODIK VIZSGÁLAT KUTATÁSI CÉLJAI ÉS HIPOTÉZISEI .......................................................................

7.3. A HARMADIK VIZSGÁLAT KUTATÁSI CÉLJAI ÉS HIPOTÉZISEI .....................................................................75

8. AZ EMPIRIKUS VIZSGÁLATOKBAN RÉSZT VEVŐ MINTA JELLEMZŐI.....................................77

8.1. ELSÖ VIZSGÁLAT: A TUDATELMÉLET ÉLETKORI KÜLÖNBSÉGEINEK VIZSGÁLATA ………………………....77

8.2. MÁSODIK VIZSGÁLAT: A TUDATELMÉLET ÉS A MUNKAMEMÓRIA KAPACITÁS KAPCSOLATÁNAK

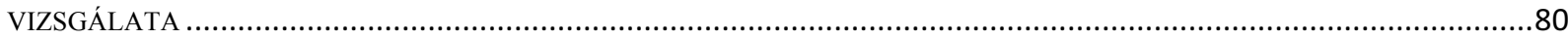

8.3. HARMADIK VIZSGÁLAT: A TUDATELMÉLET ÉS A TÁRSAS VISELKEDÉS KAPCSOLATÁNAK VIZSGÁLATA .......80

9. AZ EMPIRIKUS VIZSGÁLAT MÓDSZEREI....................................................................................

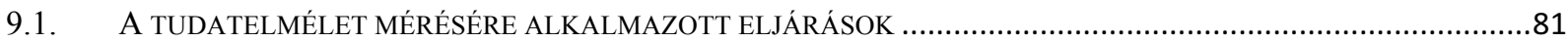

9.1.1. A kognitiv tudatelmélet mérésére alkalmazott eljárás kisiskolás korban .......................................81

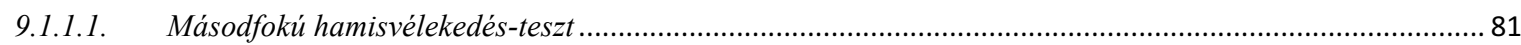

9.1.2. Az affektiv tudatelmélet mérésére alkalmazott eljárások az egész mintán ....................................82 


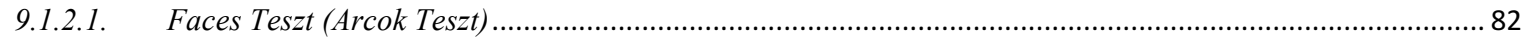

9.1.3. A komplex (kognitiv és affektiv) tudatelmélet mérésére alkalmazott eljárások az egész mintán .......82

9.1.3.1. Faux Pas Felismerése Teszt-gyermek változat (5-11 éves korú vizsgálati személyek vizsgálatára) ........... 82

9.1.3.2. Faux Pas Felismerése Teszt - felnött változat (11-12 éves kortól alkalmazott eljárás) ..............................84

9.2. A KOGNITÍV FUNKCIÓK MÉRÉSÉRE ALKALMAZOTT ELJÁRÁSOK ...........................................................87

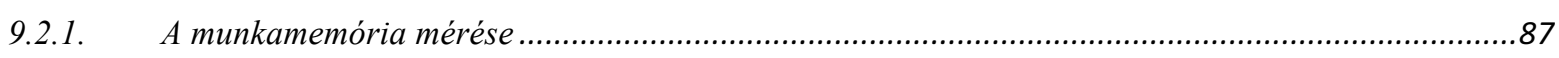

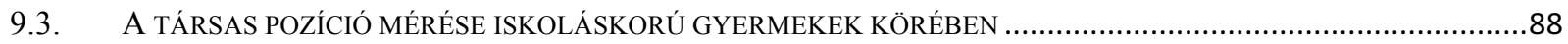

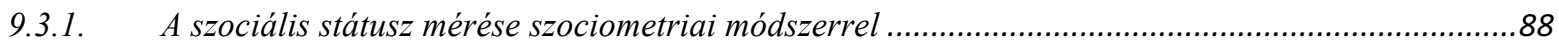

9.4. A VIZSGÁLATSOROZATBAN ALKALMAZOTT MÉRÖESZKÖZÖK FELVÉTELE..............................................90

10. AZ EMPIRIKUS VIZSGÁLAT EREDMÉNYEI

10.1. A TUDATELMÉLETI KÉPESSÉG ÉLETKORI VÁLTOZÁSAINAK ÉS A TUDATELMÉLETI TESZTEK KÖZÖTTI

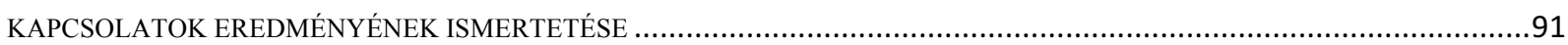

10.1.1. A tudatelméleti képesség életkori különbségei az 5-11 éves korú mintában ..................................92

10.1.1.1. A Faux Pas Felismerése Teszt gyermek tesztváltozatának életkori különbségei ...................................... 92

10.1.1.2. A Faces Teszt életkori különbségei az 5-11 éves korosztályban .............................................................. 96

10.1.1.3. Nem szerinti különbségek a tudatelméleti müködés tekintetében az 5-11 éves gyermekek körében .............. 99

10.1.1.4. A tudatelméleti tesztek közötti kapcsolatok az 5-11 éves korú mintában...................................................99

10.1.2. A tudatelméleti képesség életkori különbségei az 11-75 éves korú mintában ...............................101

10.1.2.1. A Faux Pas Felismerése Teszt felnött változatának életkori különbségei................................................ 101

10.1.2.2. A Faces Teszt életkori különbségei az 11-75 éves korosztályban ........................................................... 105

10.1.2.3. Nem szerinti különbségek a tudatelméleti müködésben az 11-75 éves korú mintában ............................... 106

10.1.2.4. A tudatelméleti tesztek közötti kapcsolatok az 11-75 éves korú mintában .............................................. 107

10.2. A MÁSODIK VIZSGÁLATBAN KAPOTT EREDMÉNYEK ISMERTETÉSE.....................................................109

10.2.1. A tudatelmélet és a munkamemória kapacitás közötti összefüggések vizsgálata a 7-11 éves életkorú mintán $\quad 110$

10.2.1.1. A Faux Pas Felismerése Teszten elért tudatelméleti teljesitmény és a munkamemória kapacitás közötti összefüggések a 7-11 éves életkorú mintában .......................................................................................... 110

10.2.1.2. A Faces Teszten elért tudatelméleti teljesitmény és a munkamemória kapacitás közötti összefüggések a 7-11 éves életkorú mintában ... 112

10.2.2. A tudatelmélet és a munkamemória kapacitás közötti összefüggések vizsgálata a 11-75 éves életkorú mintán $\quad 114$

10.2.2.1. A Faux Pas Felismerése Teszten elért tudatelméleti teljesitmény és a munkamemória kapacitás közötti összefüggések a 11-75 éves életkorú mintában 114

10.2.2.2. A Faces Teszten elért tudatelméleti teljesitmény és a munkamemória kapacitás közötti összefüggések a 11-

75 éves életkorú mintában

10.3. A HARMADIK VIZSGÁLATBAN KAPOTT EREDMÉNYEK ISMERTETÉSE.....

10.3.1. A szociometriai pozíció és a tudatelméleti müködés közötti összefüggések vizsgálata az egyszerü csoportositás alapján......

10.3.2. A szociometriai pozíció és a tudatelméleti müködés közötti összefüggések vizsgálata a sztenderdizált mutatók alapján.

10.3.3. A társak általi elfogadottság vagy elutasitottság és a tudatelméleti müködés közötti összefüggések vizsgálata korrelációs elemzéssel.....

11. AZ EREDMÉNYEK ÖSSZEGZÉSE, KITEKINTÉS ÉS TOVÁBBI KUTATÁSI IRÁNYOK. 127

11.1. A TUDATELMÉLETI KÉPESSÉG ÉLETKORI KÜLÖNBSÉGEI .... 127

11.2. A TUDATELMÉLETI KÉPESSÉG ÉS A MUNKAMEMÓRIA KAPACITÁS KÖZÖTTI ÖSSZEFÜGGÉSEK ...................132

11.3. A TUDATELMÉLETI KÉPESSÉG ÉS A TÁRSAS POZÍCIÓ KÖZÖTTI ÖSSZEFÜGGÉSEK ......................................135

11.4. KUTATÁSUNK JELENTŐSÉGE, KORLÁTAI, TOVÁBBI KUTATÁSI LEHETŐSÉGEK ÉS FEJLESZTÉSI IRÁNYVONALAK . 


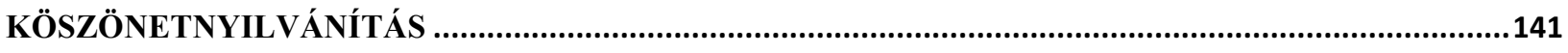

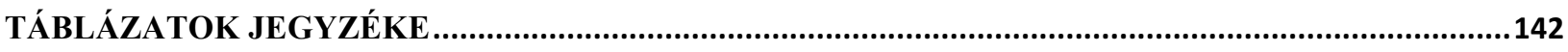

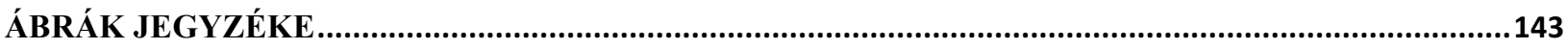

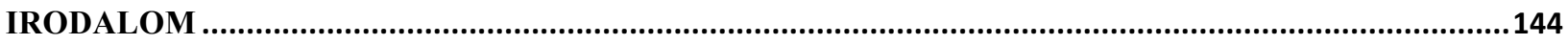

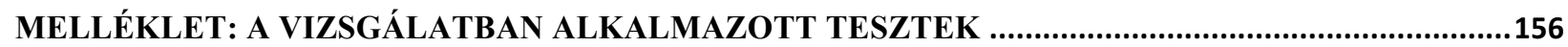

MÁSODFOKÚ, VERBÁLIS HAMIS VÉLEKEDÉS-TULAJDONÍTÁSI FELADAT (STEFANIK, 2005 NYOMÁN) .....................156

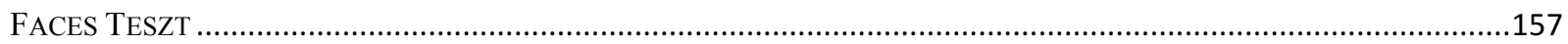

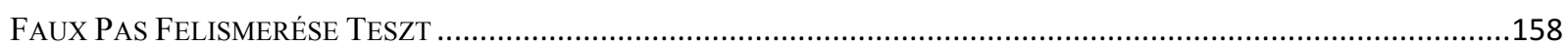

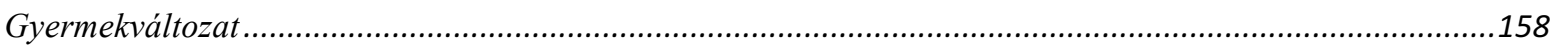

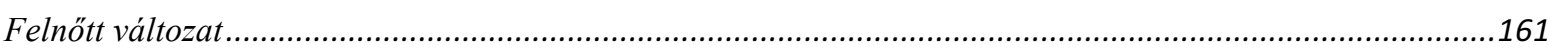

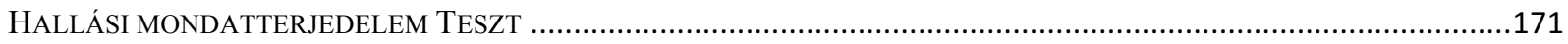

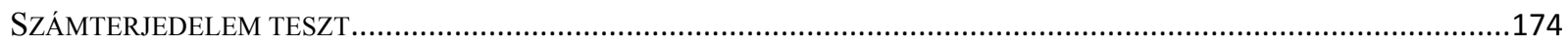

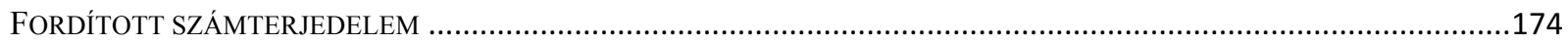

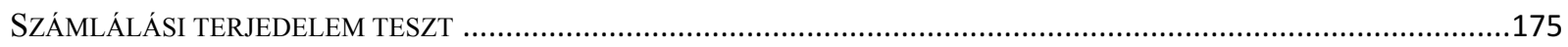

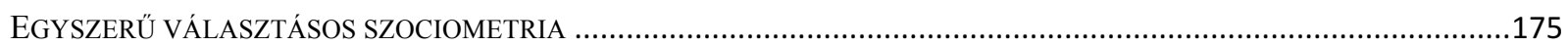




\section{BEVEZETÉS}

A tudatelmélet és fejlödésének vizsgálata a fejlődéslélektan egyik központi kutatási témája. Az utóbbi évtizedekben a tudatelméletet középpontba helyező kutatások nagyon szerteágazóak, ugyanis a tudatelmélet fogalmának felvetése főemlősökkel végzett kísérlethez köthető (Premack és Woodruff, 1978). A humán vizsgálatokban a tudatelméletre számos más kifejezéssel is utalnak, említik a naiv pszichológia, a népi pszichológia, az elmeteória, az elmeolvasás vagy a mentalizáció kifejezéseket (Bíró, 2002; Kiss, 2005). Mindezek az elnevezések egy olyan képességre utalnak, amellyel mentális állapottulajdonításra vagyunk képesek, ez pedig mások viselkedésének magyarázatát, bejóslását segíti, társas müködésünk egyik fontos képessége (Baron-Cohen, 2001; Brüne és Brüne-Cohrs, 2006).

A tudatelméleti kutatások egyik fókusza a fejlödési zavarok, ezen belül az autizmusspektrum-zavar vizsgálata. Egy sokat idézett vizsgálat Baron-Cohen, Leslie és Frith (1985) nevéhez köthető. Eredményeik egyik legfontosabb következtetése, hogy az autizmusspektrum-zavarban „elmevakság” feltételezhető, vagyis az autizmusban hiányzik a tudatelmélet képessége (Baron-Cohen, 1997), ez az elképzelés adta az autizmus magyarázatának egyik hipotézisét, a naiv tudatelméleti deficit hipotézist. A későbbi kutatások eredményeinek alapján a tudatelméleti deficit nem egymagában magyarázza az autizmust, hanem a komplex kognitív mintázat egyik fontos eleme (Györi, Borsos és Stefanik, 2014).

Saját vizsgálatainkban az iskolai sikeresség, a megfelelő társas alkalmazkodás szempontjából a tipikus fejlődésmenettel kapcsolatos vizsgálatok érdekesek, jelen disszertáció középpontjában is a tipikus fejlődés áll. A tipikus fejlődés vizsgálata mellett a tudatelmélet zavarainak feltérképezése is számos kutatást eredményezett mind a fejlődési zavarral (pl. autizmus: Baron-Cohen és mtsai, 1999; Lombardo és Baron-Cohen, 2011; Senju, 2013, Györi, Borsos és Stefanik, 2014; ADHD-ban: Uekermann és mtsai, 2010), mind pszichiátriai zavarokkal (pl. skizofrénia: Shamay-Tsoory és mtsai, 2007; Varga, Tényi, Fekete és Herold, 2008; borderline személyiségzavar: Harari és mtsai, 2010; Choi-Kain és Gunderson, 2008, anorexia nervosa: Tchanturia és mtsai, 2004; Russel és mtsai, 2009; Gál, Egyed, Pászthy és Németh, 2011) vagy neurológiai zavarral (pl. Parkinson-kór: Bodden és mtsai, 2010; Poletti és mtsai, 2013; demenciák: Gregory és mtsai, 2002; Stone és mtsai, 2003) diagnosztizált személyek körében. 
A tipikus fejlödéssel kapcsolatos kutatások szerint a csecsemőkorban is vizsgálhatók már olyan folyamatok, amelyek a tudatelmélet implicit müködésének bizonyítékai (pl. Clements és Perner, 1994; Onishi és Baillargeon, 2005; Kovács, Téglás és Endress, 2010). Óvodáskorban, négyéves gyermekeknél figyelhető meg a hamis vélekedés megértésének képessége (Wimmer és Perner, 1983; Hogrefe, Wimmer és Perner, 1986; Baron-Cohen, Leslie és Frith, 1985; Brüne és Brüne-Cohrs, 2006). A hamisvélekedés-teszttel mért tudatelméleti teljesítmény óvodáskorban kapcsolatban áll a végrehajtó funkciókkal (pl. Carlson és Moses, 2001; Carlson, Moses és Breton, 2002; Razza és Blair, 2009), számos környezeti tényezővel (pl. Dunn és mtsai, 1991; Cutting és Dunn, 1999; Pears és Moses, 2003), illetve a különféle módszerekkel mért szociáliskompetencia-összetevőkkel (pl. Lalonde és Chandler, 1995; Razza és Blair, 2009). Az iskoláskor kezdetétől, a hamis vélekedés megértésén túl, hatéves korban megfigyelhető a beágyazott mentális állapottulajdonítás, majd az irónia, humor megértése (Brüne és BrüneCohrs, 2006; Westby és Robinson, 2014), és 9-11 éves korban a társas helyzetben elkövetett baklövések, faux pas-k felismerése (Baron-Cohen, O’Riordan, Stone, Jones és Plaisted, 1999). A tudatelméleti képesség a serdülőkor végéig, fiatal felnőttkorig változik (Dumontheil és mtsai, 2010; Sebastian és mtsai, 2012; Altgassen és mtsai, 2014), majd idős korban hanyatlást mutat (Maylor és mtsai, 2002; Duval és mtsai, 2010). A kutatások nagy többsége keresztmetszeti stratégiát alkalmazott, illetve néhány életkori csoport (pl. fiatal felnőttek, idősek és nagyon idős személyek) összehasonlítása alapján vontak le következtetéseket az életkori változásokra vonatkozóan.

A tudatelmélet kapcsolata vagy függetlensége más kognitív képességektől számos kutatást ösztönzött, az eredmények a szerteágazó kutatási stratégiák alapján vitára adhatnak okot, azonban a vizsgálatok jelentős része mégis arra utal, hogy már óvodáskorban (pl. Carlson, Moses és Breton, 2002; Müller, Liebermann-Finestone, Carpendale, Hammond és Bibok, 2012), illetve a későbbiekben, felnőtt és idős korban (pl. German és Hehman, 2006; Duval és mtsai, 2010) is kimutatható a tudatelméleti működés és a végrehajtó funkciók, illetve a munkamemória kapcsolata (Lin, Keysar és Epley, 2010; Phillips és mtsai, 2011). Vagyis felmerül annak a kérdése, vajon mennyire müködik automatikusan felnőtt korban a mentalizáció, ha az egyidejüleg végzett memóriafeladatok rontják a tudatelméleti teljesítményt (McKinnon és Moscovitch, 2007). Ugyanakkor maga a társas megismerés folyamata implicit és explicit módon is müködhet (pl. Frith és Frith, 2008), ennek kapcsán feltehetően a tudatelméleti müködés is lehet implicit, vagyis automatikus, kevésbé rugalmas folyamat, illetve explicit, azaz nem 
automatikus folyamat, mely nagyobb mértékben terheli az egyén kognitív erőforrásait (pl. Apperly, 2011). Viszont a legtöbb vizsgálatban az explicit tudatelméleti müködést mérő vizsgálóeljárásokat alkalmazva mutatták ki a kognitív funkciók és a tudatelmélet közötti kapcsolatokat (pl. Razza és Blair, 2009).

A kognitív funkciókkal való kapcsolat mellett a kutatások egy másik iránya a társas viselkedéssel való feltételezett összefüggések elemzése. Az alapvető kérdése e kutatásoknak az, vajon a sikeresebb tudatelméleti teljesítmény sikeresebb társas viselkedéssel, magasabb szociális kompetenciával jár-e együtt. A kutatási eredmények ellentmondásosak, ez egyrészt módszertani kérdésekre vezethető vissza: a vizsgálatokban alkalmazott tudatelméleti tesztek kellően realisztikusak-e, hiszen egy laboratóriumi teszten elért jó eredmény nem feltétlenül jelzi előre a sikeres társas alkalmazkodást (Astington, 2003). Az ellentmondások másik oka az, hogy a jó tudatelméleti müködést sokan antiszociális célra használják, például az iskolai zaklató gyermekekkel kapcsolatos vizsgálatok is erre utalnak, ezt viszont nem tekintjük sikeres társas müködésnek az iskolában (Slaughter és Repacholi, 2003; Sutton, 2003). A kutatási eredmények többsége abba az irányba mutat, hogy mind óvodáskorban (pl. Watson, Nixon, Wilson és Capage, 1999; Walker, 2005), mind iskoláskorban (pl. Banerjee és Watling, 2005; Liddle és Nettle, 2006), longitudinális kutatási stratégiával (pl. Banerjee, Watling és Caputi, 2011) is kimutatható kapcsolat a társas müködés és a tudatelméleti képesség között, azonban jelenleg az ok-okozati viszonyok nem egyértelmüek. A kutatások áttekintéséből kitünik, hogy a feltételezett összefüggések gyengék vagy mérsékeltek a társas hatékonyság és a tudatelméleti müködés között, illetve az alkalmazott módszerek akár a társas viselkedés, akár a mentális állapottulajdonítás mérésére nagyon heterogének, így egységes következtetésként inkább a gyenge összefüggés vonható le a kutatások alapján.

Jelen disszertáció és saját vizsgálatsorozatunk célja, hogy azonos tudatelméleti mérőeljárásokat alkalmazva, széles életkori spektrumon vizsgáljuk meg a tudatelméleti képesség életkori különbségeit, a kognitív funkciókkal, ezen belül is elsősorban a munkamemória kapacitással való kapcsolatát, illetve különböző elemzési módszerek alapján megállapított társas hatékonysággal való összefüggéseit. Saját vizsgálataink középpontjában az explicit, verbalizált tudatelméleti müködés feltárása áll, ennek mérésére a Faux Pas Felismerése Teszt gyermekekre (Baron-Cohen és mtsai, 1999) és felnőttekre (Stone, Baron-Cohen és Knight, 1998) kialakított változatát alkalmaztuk. Az iskoláskorú populációban, 7-11 éves kor között mérő tesztet, illetve a felnőtt változatot tipikus és atipikus müködés vizsgálatában is alkalmazzák (pl. Banerjee és 
Watling, 2005; Harari és mtsai, 2010), akár módosított formában (pl. Banerjee, Watling és Caputi, 2011), ugyanakkor a tudatelmélet realisztikus mérésére alkalmas eljárásnak tekinthető. A teszt eredeti változatának magyarra fordítása hiánypótló, saját fordításban alkalmaztuk az eljárásokat a vizsgálatsorozatokban, tapasztalataink szerint megfelelően alkalmazható eljárás az explicit tudatelméleti képesség mérésére (Gál, Egyed, Pászthy és Németh, 2011; Gál, Katona, Janacsek és Németh, 2014).

A disszertáció elméleti áttekintést tartalmazó fejezeteiben a tudatelmélet fogalmát, komponenseinek rendszerét, illetve az idegtudományi kutatások nyomán a neurológiai hátterét mutatjuk be. A második fejezetben ismertetjük a tudatelmélet mérésére gyakran alkalmazott eljárásokat, majd a harmadik fejezetben az életkori változásokat tekintjük át csecsemőkortól idős korig, illetve a fejlődésben szerepet játszó környezeti tényezőkkel kapcsolatos kutatási eredményeket ismertetjük. Az ötödik és a hatodik fejezetben a tudatelmélet összefüggéseit mutatjuk be elsőként a végrehajtó funkciókkal és a munkamemória kapacitással, majd a társas viselkedéssel. A hetedik fejezetben a vizsgálatsorozat felépítését, céljait és hipotéziset, a nyolcadik fejezetben a vizsgálatsorozatban részt vevő személyek jellemzőit, a kilencedik fejezetben az alkalmazott módszereket ismertetjük. A tizedik fejezetben mutatjuk be a vizsgálatsorozat eredményeit, elsőként a tudatelmélet életkori külöbségeivel kapcsolatos eredményeket magyar mintán, majd a következő alfejezetben a munkamemória-kapacitással, végül a társas pozícióval kapcsolatos összefüggések eredményeit mutatjuk be. A disszertációt az összegzés és a további kutatási lehetőségeket kijelölő fejezet zárja. A fejezetek közül néhány alapját korábban megjelent önálló vagy társzerzővel közös munka alkotja (Gál, Egyed, Pászthy és Németh, 2011; Gál, Katona, Janacsek és Németh, 2014; Gál, 2015; Gál és Kasik, 2015a; Gál és Kasik, 2015b).

A disszertáció célja elsősorban a tudatelméleti képesség életkori különbségeinek, kognitív funkciókkal és a társas pozícióval való kapcsolatának vizsgálata. A vizsgálatsorozat több szempontból hiánypótló, szeretnénk egy olyan mérőeszközt kialakítani magyar nyelven, ami az iskoláskorú gyerekek, illetve a serdülő, a felnőtt és az idős korú személyek tudatelméleti képességének mérésére alkalmas lehet mind tipikus, mind atipikus mintán. Továbbá a saját fordításban ismertetett mérőeszköz kialakítása, majdani továbbfejlesztése céljából fontos megvizsgálni, hogy a tudatelméleti teljesítmény összefüggést mutat-e a munkamemória kapacitással, illetve a társas pozícióval kimutatható-e együttjárás iskoláskorú gyermekek mintáján. Ez utóbbi elsősorban a későbbi fejlesztési programok kialakítása szempontjából, illetve 
bullying prevenciós programok alkalmazása miatt fontos. Hiszen amennyiben feltárható a tudatelméleti és a társas müködés között kapcsolat, akkor érdemes figyelembe venni a mentalizáció fejlesztésére irányuló módszerek beépítését egy komplex iskolai fejlesztési programba, vagy tantermi keretbe, tartalomba ágyazottan.

Az iskolai oktatás elsősorban az analitikus gondolkodási folyamatokra, az intelligenciát igénylő feladatok megoldására helyezi a hangsúlyt, holott iskoláskorban, különösen a serdülőkorban az agy természetszerűleg inkább a mentalizációs hálózatot használva a társas világ feltérképezése, kezelése irányában müködne. Emiatt érdemes lenne megfontolni, hogyan építhetők be a tantermi oktatásba a szociális kognícióval kapcsolatos módszerek, lehetőségek, egy integrált, oktatásban alkalmazható szociális idegtudomány kialakítása felé haladva (Lieberman, 2012). Ez a felvázolt cél nagyon távoli, ugyanakkor az iskolai oktatás, a gyerekek iskolai sikeressége, hatékony társas fejlesztésük kapcsán megfontolandó szemlélet az iskoláskorú gyerekek tudatelméleti fejlettségének vizsgálata, és ennek gyakorlati alkalmazhatósága szempontjából. 


\section{A TUDATELMÉLET FOGALMÁNAK MEGHATÁROZÁSA, IDEGTUDOMÁNYI KÉRDÉSEI}

\subsection{A tudatelmélet fogalma és megközelitései}

A tudatelmélet képességének meghatározására többféle elnevezés és definíció ismert (Baron-Cohen, 2001; Allen, Fonagy és Bateman, 2011; Csibra és Gergely, 2002; Apperly, 2011), több komponensből álló rendszerként definiálják ezt a képességet (pl. Shamay-Tsoory és mtsai, 2010; Tine és Luciarello, 2012; Dennis és mtsai, 2013). Szinonimaként használják a mentalizáció, az elmeolvasás, elmeteória, naiv pszichológia fogalmait, azonban más-más kontextusban említve öket (Baron-Cohen, 2001; Bíró, 2002; Kiss, 2005; Brüne és Brüne-Cohrs, 2006; Allen, Fonagy és Bateman, 2011; Apperly, 2011). A disszertációban a továbbiakban a tudatelmélet kifejezést alkalmazzuk a képesség meghatározására, ugyanakkor röviden ismertetjük a mentalizáció fogalmát és összetevőit is, mivel gyakran megjelenik a pszichológiai szakirodalomban (pl. Bateman és Fonagy, 2004; Varga, Tényi, Fekete és Herold, 2008).

A tudatelmélet (Theory of Mind - ToM) általános társas-kognitív képességünk, mely segítségével magunknak és másoknak elmemüködést feltételezünk, vagyis mentális állapotokat tulajdonítunk, például vélekedést, vágyat, képzeletet, szándékot, érzést stb. A tudatelméleti képesség birtokában tehát képesek vagyunk más emberek elméjének tartalmára következtetni és reagálni. Ez a képesség automatikusan müködik felnőttkorban (Kiss, 2005; Bíró, 2002, BaronCohen, 2001; Egyed és Király, 2008; Apperly, 2011). A kutatásom szempontjából kulcskérdés, vajon a tudatelmélet fejlődése, életkori változása hogyan megy végbe, milyen faktorok vannak hatással a tudatelmélet müködésére és milyen életkori különbségek mutathatók ki óvodáskortól időskorig.

A mentalizáció kifejezés a pszichológiai kutatásokban gyakran alkalmazott fogalom, részletes áttekintést Allen, Fonagy és Bateman (2011) ad, ismerteti a tudatelmélet és a mentalizáció fogalmai közötti főbb különbségeket. A mentalizáció olyan emberi aktivitás, segítségével a viselkedést mentális állapotokhoz kapcsolódóan értjük meg, tudatában vagyunk saját magunk vagy a másik ember mentális állapotainak. A szerzők szerint „,a mentalizáció lényege, hogy az egyik ember elméje tartalmazza a másikét” (Allen, Fonagy és Bateman, 2011, 
2. o.). A mentalizáció kifejezés azt jelenti, hogy úgy értelmezünk egy viselkedést, hogy célirányos mentális állapotokhoz kötjük, vagyis a viselkedés mögött mentális állapotokat feltételezünk. A mentalizáció és a tudatelmélet közötti eltéréseket három pontban fogalmazzák meg: a tudatelméleti kutatások (1) a mentalizáció fejlődésének kognitív aspektusával foglalkoznak, (2) mások értelmezését helyezik előtérbe, (3) a tudatelmélet a mentalizációs működés folyamatosan fejlődő terméke, a mentalizáció számára egy fogalmi keretet biztosít (Allen, Fonagy és Bateman, 2011). Ezek a különbségtételek arra utalnak, hogy a tudatelméleti kutatások szükebbek és korlátozottabbak a mentalizáció kutatásánál, a tudatelmélet fogalmát és komponenseit (melyek már nem csak a kognitív, hanem az affektív aspektusokat is figyelembe veszik) ismertetjük a továbbiakban.

A tudatelmélet fogalmának eredeti, szük értelme szerint: „az a mechanizmus, amellyel másoknak (és néha magunknak) reprezentációs jellegü, a valós, vagy egy lehetséges világot leképező mentális állapotokat, tehát vélekedéseket, tudást, vágyakat, szándékokat tulajdonítunk, és nem foglalkozunk azokkal a készségekkel (empátia, utánzás, érzelmi állapotok észlelése, kommunikáció stb.), amelyek nem, vagy nem feltétlenül járnak együtt mentális attribúcióval" (Csibra és Gergely, 2002, 56. old.). Premack és Woodruff (1978) csimpánzokkal végzett kísérletsorozatát tárgyaló tanulmányukban úgy vélekednek, hogy ha az egyén rendelkezik tudatelmélettel, akkor mentális állapotokat tulajdonít önmagának és másoknak is, akár fajtársról, akár más fajról legyen szó. Véleményük szerint a tudatelmélet elméletnek tekinthető, hiszen a mentális állapotok közvetlenül nem megfigyelhetők, illetve a rendszer predikciók megtételére használható. A tudatelmélet elmélet-elmélet megközelítését részletesebben a 3.5. fejezetben ismertetjük.

A tudatelmélet megléte elengedhetetlen a társas alkalmazkodáshoz, ennek birtokában képesek vagyunk a velünk interakcióba lépő egyének viselkedését elöre jelezni, magyarázni, értelmezni, továbbá segíti kommunikációnkat, szerepe van a kooperációban, a viselkedés irányításában és befolyásolásában, interakció kezdeményezésében és fenntartásában. A tudatelmélet nélkül tehát a szociális alkalmazkodásunk jóval nehezebbé válna, felélénkült a terület kutatása a pszichológia és a pszichiátria területén is (Kiss, 2005; Walker, 2005). 


\subsection{A tudatelmélet komponenseinek meghatározása}

A tudatelméletet különböző összetevőkből álló rendszerként képzelik el, az utóbbi időben született kutatások rávilágítanak arra, hogy a tudatelméletet nem egy egységes konstruktumként definiáljuk, hanem különböző összetevőkből álló rendszerként (pl. Shamay-Tsoory és mtsai, 2010; Tine és Luciarello, 2012; Dennis és mtsai, 2013). Ezek agyi korrelátumait is intenzíven kutatják (Kalbe és mtsai, 2010; Abu-Akel és Shamay-Tsoory, 2011; Dvash és Shamay-Tsoory, 2014). Az alábbiakban olyan megközelítéseket ismertetek, melyek többkomponensú rendszerként definiálják a tudatelméleti képességet.

Különbség tehető a tudatelmélet két komponense között, így beszélhetünk kognitív és affektív tudatelméletről (Shamay-Tsoory és Aharon-Peretz, 2007; Shamay-Tsoory és mtsai, 2010). Kognitív tudatelmélet alatt azt értjük, amikor az egyén racionálisan reagál más emberek mentális állapotaira, vagyis gondolkodik mások vélekedéseiről (Shamay-Tsoory és AharonPeretz, 2007; Shamay-Tsoory és mtsai, 2010; Bodden és mtsai., 2010; Poletti és mtsai, 2011). Affektív tudatelméleten pedig azt értjük, amikor más emberek érzéseiről vélekedünk. (ShamayTsoory és Aharon-Peretz, 2007; Shamay-Tsoory és mtsai, 2010; Bodden és mtsai, 2010; Poletti és mtsai, 2011). A kognitív és affektív tudatelmélet agyi hátterét az 1.3. fejezetben tárgyaljuk. Fontosnak tartja azonban az affektív tudatelmélet és az empátia fogalmainak integrálását Shamay-Tsoory és munkatársai (2010), valamint Dvash és Shamay-Tsoory (2014) tanulmányukban. Az empátia - ahogyan a ToM is - szintén kognitív és affektív komponensre bontható. A kognitív empátiához kapcsolódik az affektív tudatelmélet, mivel az affektív ToM magába foglalja az empátia kognitív aspektusait. Az affektív tudatelmélet bizonyos mértékig köthető az érzelmi/affektív empátiához is, hiszen interakcióban állnak egymással. A kognitív tudatelmélet az affektív tudatelméletet megalapozó komponens Shamay-Tsoory és munkatársai (2010) modelljében. A kognitív és affektív empátia illetve tudatelmélet közötti különbségtételt elsősorban az érzelmek központi szerepe jelöli ki. Az empátia további összetevőjeként tekinthető az úgynevezett érzelmi fertőzés, mely támogatja azt a képességünket, hogy szimuláljuk mások érzelmeit, érzelmi állapotait (Shamay-Tsoory és mtsai, 2010). Az egyes empátia és tudatelméleti komponensek az ismertetett modellben a következő módon kapcsolódnak össze, ahogyan az 1. ábrán látható. 


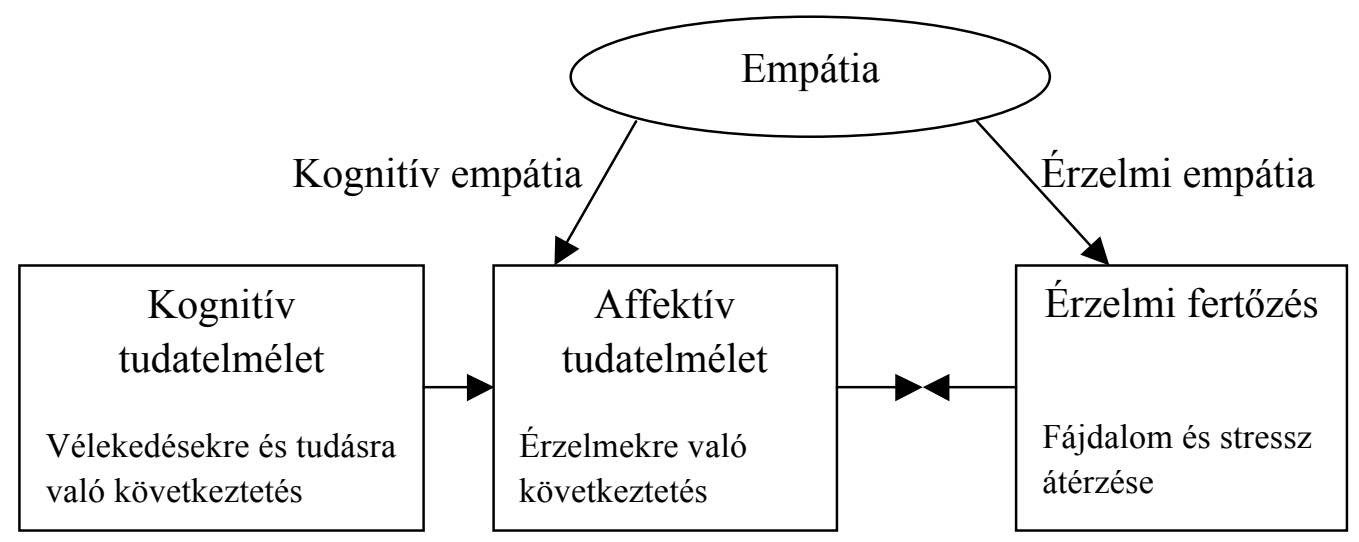

1. ábra: A kognitív és az affektív tudatelmélet, valamint az empátia összetevőinek kapcsolata Shamay-Tsoory és munkatársai (2010) nyomán (669. o.)

Dennis és munkatársai (2013) a már ismertetett kognitív és affektív elkülönítés mellett azonban hármas felosztását javasolja a tudatelméletnek. A kognitív és az affektív tudatelmélet mellett konatív komponensről is említést tesznek traumás agysérüléssel élő gyermekekkel végzett vizsgálatuk kapcsán. Három részből álló modelljükben a kognitív tudatelmélet alatt az elmeolvasás klasszikus folyamatát értik, vagyis mások elméje tartalmának megértését, illetve a kognitív vélekedések, a hamis vélekedés megértését értik alatta. Az affektív tudatelmélethez sorolják az érzelmek kifejezését és az érzelmi kommunikációt is. A konatív, vagyis a viselkedéses tudatelmélet alatt értik a szociális kommunikáció azon formáit, amelyek segítségével az emberek más személyek mentális és érzelmi állapotait próbálják befolyásolni.

Megkülönböztetünk továbbá explicit és implicit tudatelméletet, a vizsgálati eredmények szerint az implicit tudatelmélet korábbi életkorban jelenik meg, mint az explicit forma. Az implicit tudatelmélet nem szándékos, nem tudatos, nem verbalizált, míg az explicit tudatelmélet a verbálisan is kifejezett, szándékos és tudatos mentálisállapot-tulajdonítást jelenti (Clements és Perner, 1994). Frith és Frith (2008) tágabb értelemben, a társas megismerés kapcsán különböztetnek meg implicit és explicit szociális kogníciót. Az implicit folyamatok elsősorban automatikusak, gyorsak, nem tudatosak, míg az explicit folyamatok tudatosak, nem automatikusak, gyors információfeldolgozást tesznek lehetővé, viszont nagyobb erőfeszítést kívánnak meg az egyéntől, hiszen igénybe veszik az általános kognitív müködést, illetve verbális kifejeződést tesznek lehetővé (Frith és Frith, 2008; Győri, Borsos és Stefanik, 2014). 
Az explicit és implicit elkülönítést Allen, Fonagy és Bateman (2011) is leírják a mentalizáció kapcsán, ez a megközelítés hasonló a Frith és Frith (2008) által leírtakhoz. Az explicit mentalizáció szimbolikus, vagyis például azért beszélünk vagy írunk verset, mert saját mentális állapotunkat szeretnénk kifejezni. Az explicit mentalizáció fő közege a nyelv, elsősorban narratíván keresztül zajlik, nagyrészt tudatos, szándékolt és reflektív. A jól müködő explicit mentalizációra a pontosság, a rugalmasság és a gazdagság jellemző. Az implicit mentalizáció ugyanakkor automatikus és nem reflektív, például akkor érhető tetten, ha empatizálás közben automatikusan, tudattalanul tükrözzük a másik ember arckifejezését, testtartását. Vagyis implicit mentalizáció közben képesek vagyunk tudatos erőfeszítés nélkül a másik ember nézőpontjába helyezni magunkat. Az implicit mentalizáció procedurális igeranyag, gyakran intuíciónak nevezzük, míg az explicit inkább szimbolikus formában fogalmazódik meg. Nehéz azonban az explicit és implicit mentalizáció közötti határvonalat meghúzni, hiszen mentalizálás közben a két forma között váltunk (Allen, Fonagy és Bateman, 2011). Az implicit és explicit megkülönböztetés mellett saját magunkra vagy másokra vonatkozó, illetve különböző időbeli keretek közötti és változó hatókörben megjelenő mentalizáció is elkülöníthető.

Apperly (2011) két elkülönülő rendszert feltételez az elmeolvasáshoz szükséges kognitív folyamatok feldolgozása alapján, megközelítésében két dimenziót alkalmaz. A vertikális dimenzióban elkülöníti az alacsonyabb és a magasabb szintű folyamatokat, a horizontális dimenzió pedig az elmeolvasás potenciális folyamatait különíti el. A vertikális dimenzióban az egyik rendszer alacsonyabb szintü, gyors, automatikus, de kevésbé rugalmas információfeldolgozást tesz lehetővé, kevésbé veszi igénybe az általános kognitív funkciókat, nem vagy kevésbé tudatos (implicit, automatikus). A másik rendszer magasabb szintü, környezet-függő és rugalmas, azonban nagymértékü kognitív terheléssel jár, jelentősen igénybe veszi a figyelmi, az emlékezeti és a végrehajtó funkciókat. Az elmeolvasási képességeknek egyszerre rugalmasnak kell lenniük ahhoz, hogy lehetővé váljon a komplex mentális állapotok megértése, az ezekről való gondolkodás, de ezzel egy időben kellően gyorsnak és hatékonynak kell lennie annak érdekében, hogy percről percre eligazodhassunk a társas interakciókban. A horizontális dimenzióban elkülöníti a tudatelméleti müködés lehetséges alfolyamatait. A szerző szerint az elmeolvasásban részt vevő kognitív folyamatokhoz tartoznak a mentális állapotokkal kapcsolatos következtetéseknek, az információk tárolásának képessége, illetve az információk felhasználása további folyamatok számára. Mindez azt jelenti, hogy az elmeolvasás nem feltétlenül jár együtt a viselkedéssel kapcsolatba hozható mentális állapotok kikövetkeztetésével, 
ez az erőfeszítés elképzelhető, hogy más személyek nézőpontjának emlékezetben tartásában jelentkezik, de nem feltétlenül biztos, hogy ezt az információt az egyén használja, ha az szükséges (Apperly, 2011).

A tudatelmélet komponenseinek azonosításában Tine és Lucariello (2012) a szociális, azaz az interperszonális és az intraperszonális gondolkodást különíti el aszerint, hogy a gondolkodási folyamat középpontjába az egyén maga, vagy egy másik személy áll. Míg az interperszonális tudatelméleti müködés alatt más személyek vélekedéseiről és érzelmeiről való gondolkodást, addig az intraperszonális tudatelmélet alatt a saját vélekedésekről vagy érzésekről való gondolkodást, illetve reflektálást értik. A sikeres társas interakciók megvalósításához a szociális/interperszonális tudatelmélet müködése fontos (Tine és Lucariello, 2012; Westby és Robinson, 2014).

A komponensekről összefoglaló áttekintést az 1. táblázatban közlünk.

1. táblázat: Az áttekintett tudatelméleti komponensek összefoglalása az egyes szerzők szerint

\begin{tabular}{|c|c|}
\hline Szerző/szerzők & Tudatelmélet/mentalizáció komponensei \\
\hline $\begin{array}{l}\text { Shamay-Tsoory és Aharon-Peretz } \\
(2007) \\
\text { Shamay-Tsoory és munkatársai } \\
(2010) \\
\text { Dvash és Shamay-Tsoory (2014) }\end{array}$ & $\begin{array}{l}\text { Kognitív tudatelmélet: gondolkodunk mások vélekedéseiről } \\
\text { Affektív tudatelmélet: más emberek érzéseiről való vélekedéseink }\end{array}$ \\
\hline Allen, Fonagy és Bateman (2011) & $\begin{array}{l}\text { Explicit mentalizáció: szimbolikus, szándékolt és reflektív } \\
\text { Implicit mentalizáció: automatikus, nem reflektív }\end{array}$ \\
\hline Apperly (2011) & $\begin{array}{l}\text { Automatikus: alacsonyabb szintü, gyors, automatikus, kevésbé rugalmas, } \\
\text { kevésbé veszi igénybe az általános kognitív funkciókat, nem vagy kevésbé } \\
\text { tudatos } \\
\text { Nem-automatikus: magasabb szintü, környezet-függő és rugalmas, } \\
\text { nagymértékủ kognitív terheléssel jár, jelentősen igénybe veszi a figyelmi, } \\
\text { az emlékezeti és a végrehajtó funkciókat. }\end{array}$ \\
\hline Tine és Luciarello (2012) & $\begin{array}{l}\text { Interperszonális/szociális tudatelmélet: más személyek vélekedéseiről és } \\
\text { érzelmeiröl való gondolkodás } \\
\text { Intraperszonális tudatelmélet: saját vélekedésekről vagy érzésekről való } \\
\text { gondolkodás, reflektálás }\end{array}$ \\
\hline Dennis és munkatársai (2013) & $\begin{array}{l}\text { Kognitív tudatelmélet: mások elméje tartalmának megértése } \\
\text { Affektív tudatelmélet: az érzelmek kifejezése és az érzelmi kommunikáció } \\
\text { Konatív tudatelmélet: a szociális kommunikáció, mely segítségével más } \\
\text { személyek mentális és érzelmi állapotait próbáljuk befolyásolni }\end{array}$ \\
\hline
\end{tabular}


A tudatelmélet tehát nem egykomponensü konstruktum, hanem több összetevőt, alfolyamatot tartalmaz. Annak tekintetében, hogy saját magunk, vagy mások mentális állapotaira következtetünk, elkülöníthető intraperszonális illetve interperszonális gondolkodás a tudatelmélet kapcsán. A szociális alkalmazkodásunk, a sikeres társas interakcióink feltétele lehet az interperszonális tudatelmélet müködése, hiszen ahhoz, hogy sikeresen müködjünk egy társas helyzetben, szükségünk van arra, hogy kikövetkeztessük és bejósoljuk a másik személy mentális állapotát (Tine és Luciarello, 2012). A fentebb ismertetett tudatelméleti komponensek, illetve a tudatelmélet definíciója is (pl.) a megfogalmazások szerint elsősorban a másik személy mentális állapotainak kikövetkeztetésére vonatkozik, azaz a gondolkodási folyamat középpontjában a másik személy áll, így az interperszonális tudatelmélet keretében értelmezhető. Az affektív és kognitív összetevők, ahogyan Shamay-Tsoory és munkatársai (2010) megfogalmazzák, aszerint különítik el a komponenseket, hogy a másik személy gondolatait (kognitív) vagy érzéseit (affektív) következtetjük ki. Hasonlóan, a Dennis és munkatársai (2013) által megfogalmazott három komponens, az affektív, kognitív és konatív tudatelmélet is a másik személy mentális állapotaira vonatkozik. Azaz affektív-kognitív, illetve a konatív összetevők is, mind az interperszonális tudatelmélet kapcsán értelmezhetők. Továbbá szociális kogníció (Frith és Frith, 2008) és a tudatelmélet (Clements és Perner, 1994; Győri, Borsos és Stefanik, 2014) az explicit, tudatos és szándékos, illetve az implicit, nem-tudatos elkülönítés megfogalmazása is az elvégzett kutatások mószertana alapján a másik személy mentális állapotainak kikövetkeztetésére vonatkozik. Izgalmas kutatási kérdés, hogy vajon az affektív-kognitív elkülönítés, illetve az explicit-implicit megkülönböztetés vajon a tudatelmélet intraperszonális müködésében hogyan valósulhat meg, illetve ami még nagyobb kihívást jelent, hogy vajon hogyan válik mérhetővé. Mivel jelen disszertáció vizsgálataiban a tudatelmélet életkori különbségei, munkamemória kapacitással és a társas viselkedéssel, szociometriai pozícióval való összefüggései állnak, a kutatás fő koncepciója okán az interperszonális/szociális tudatelmélet vizsgálatát tűztük ki célul, továbbá annak affektív és kognitív komponenseit vizsgáljuk, az explicit tudatelméleti müködés kapcsán. Ugyanakkor fontos megjegyezni, hogy az áttekintett összetevők nem egymást kizáró, hanem sokkal inkább integráltan megjelenő komponensei, folyamatai a tudatelméletnek még akkor is, ha az egyes összetevök fogalmilag nem feltétlenül pontosan körülhatároltak. A tudatelmélet atipikus mintázataiban megjelenő komponensek vizsgálatai mellett (pl. ShamayTsoory és Aharon-Peretz, 2007; Harari és mtsai, 2010; Győri, Borsos és Stefanik, 2014) a 
tipikus fejlődéssel kapcsolatos kutatások egyik fontos kérdése, hogy hogyan változnak az életkorral az egyes összetevők, ezáltal milyen módon integrálhatók ezek a komponensek a tudatelmélet fejlődésében (erre vonatkozó törekvést 1. Westby és Robinson, 2014), továbbá az egyes komponensek milyen módon kapcsolódnak egymáshoz, illetve milyen mechanizmusokkal, kognitív funkciókkal állnak kapcsolatban, ezek az összefüggések hogyan változhatnak az életkorral, illetve milyen neurális háttérrel rendelkeznek.

\subsection{A tudatelmélet neurális háttere}

A tudatelmélet kutatásában az egyes komponensek viselkedéses szinten történő vizsgálata mellett az agyi háttérrel foglalkozó kutatások is előtérbe kerültek. Az idegtudományi kutatások előtérbe kerülésével, illetve a tudatelmélet zavarainak vizsgálatával kapcsolatosan megindultak a kutatások a szociális kogníció idegrendszeri hátteréről. Az így kialakuló új tudományterület a szociális kognitív idegtudomány (social cognitive neuroscience), amely a társas jelenségek és folyamatok vizsgálatát tűzi ki célul a kognitív idegtudomány módszertanával, például a képalkotó eljárásokkal, elektrofiziológiai, agyi stiumlációt alkalmazó vizsgálatokkal és a neuropszichológiai vizsgálóeljárások segítségével (Lieberman, 2007). A tudatelméleti müködés idegrendszeri hátterének azonosítása kapcsán mind a neuroanatómiai, mind neurobiológiai hátteret igyekeznek feltérképezni. Amikor a tudatelmélet agyi hátteréről gondolkozunk, akkor nem egy specifikus agyi terület aktivációjára kell gondolni, hanem egy komplex agyi hálózatra (Csibra és Gergely, 2002; Apperly, 2011; Lieberman, 2012). Az agyi háttérrel foglalkozó kutatások egyik iránya a főemlősök vizsgálata, ennek kapcsán a tükörneuronok kerültek a humán kutatások érdeklődési körébe is (Csibra és Gergely, 2002). A tükörneuronok olyan idegsejtek, amelyeket makákók esetében azonosítottak. Ezek az idegsejtek aktiválódnak amikor a majom aktív mozgást végez és akkor is, amikor megfigyeli, hogy mások (akár a fajtársa, akár például egy ember) is ezt a mozgást végzi (Gallese és Goldman, 1998). Az utánzás és a cselekvések megértésének magyarázatában alkalmazták a tükörneuron elméletet (Hickok, 2009), illetve a motoros empátia és az érzelmi „fertőzés” mechanizmusának magyarázatában is (Dvash és Shamay-Tsoory, 2014). Ugyanakkor a tükörneuronokkal kapcsolatos elképzelés kritikáját nyolc pontban fogalmazza meg Hickok (2009), melyek közül néhányat emelek ki, amelyek a tudatelmélethez is köthetők: a cselekvések megértése nem kizárólag a tükörneuron rendszer alapján magyarázható, a makákók és az ember tükörneuron müködése nem párhuzamos 
egymással és az inferior frontális gyrus (ahol azonosították a tükörneuronokat) károsodása nem jár együtt a cselekvések megértésének zavarával.

A neurális háttér kutatásának másik iránya a humán vizsgálatok közül azok, amelyek képalkotó eljárás segítségével a tudatelméleti feladatok megoldása közben vizsgálják az aktiválódó agyterületeket, valamint agysérült betegek neuropszichológiai vizsgálatai alapján vonnak le következtetéseket az érintett agyterületekröl (Csibra és Gergely, 2002). Jelen disszertáció keretei között a humán vizsgálatokból származó adatok egy részére utalok a továbbiakban. Az idegrendszeri háttér vizsgálata során a kutatások igyekeznek azonosítani azt a hálózatot, másnéven mentalizációs hálózatot, ami szerepet játszik a tudatelmélet működésében. Amennyiben a kutatások sikeresen feltérképezik ezt a hálózatot, adatokat nyerhetünk azzal kapcsolatban, hogy mely területek aktiválódnak a tudatelmélet müködése közben, és ezek a területek milyen más kognitív folyamatokért felelősek, azaz kapcsolatot kereshetünk viselkedéses és idegrendszeri szinten is a tudatelmélet és más kognitív funkciók között.

A tudatelmélet neuroanatómiai korrelátumai elsősorban a mediális prefrontális kéreg struktúrái és a temporo-parietális junkció (Frith és Frith, 2003), ezek a területek még az egy évtizeddel későbbi publikációkban is fontos szerepet kapnak (Koster-Hale és Saxe, 2013). AbuAkel és Shamay-Tsoory (2011) áttekintésében összefoglalja azokat az agyi területeket, amelyek szerepet játszanak a mentális állapottulajdonítás folyamatában, melyeket 2. táblázatban foglalunk össze. Az agyi területekkel kapcsolatos adatok elsősorban képalkotó eljárásokkal végzett kutatásokból, valamint léziós vizsgálatokból származnak. 
2. táblázat: A tudatelméleti működésben kimutatható agyi területek összefoglaló táblázata AbuAkel és Shamay-Tsoory (2011) alapján (2972. o)

\begin{tabular}{l|l}
\hline Agyi terület & \multicolumn{2}{l}{ Broadmann-area } \\
\hline \hline Posterior területek & \multicolumn{2}{l}{} \\
\hline Temporo-parietális junkció (beleértve az inferior parietális lebenyt, & $39 / 40$ \\
IPL/pSTS vagy TPJ) & $31 / 7$ \\
Posterior cingulate/precuneus & $21 / 22$ \\
Superior temporalis sulcus & \\
\hline Limbikus-paralimbikus területek & $11 / 12 / 47$ \\
\hline Orbitofrontális kéreg (OFC) & $10 / 32$ \\
Ventrális mediális prefrontális kéreg (vMPFC) & $24 / 32$ \\
Anterior cinguláris/paracinguláris kéreg (ACC/PrCC) & 38 \\
Temporális pólus & szubkortikális \\
Amygdala & szubkortikális \\
Striatum & \multicolumn{2}{|l}{} \\
\hline Frontális területek & $8 / 9$ \\
\hline Dorsalis mediális prefrontális kéreg (dMPFC) & $9 / 46$ \\
Dorsalis laterális prefrontális kéreg (DLPFC) & $44 / 45 / 47$ \\
Inferior laterális frontális kéreg (ILFC) & \\
\hline
\end{tabular}

A vizsgálatok eredményei eltérnek a tekintetben, hogy melyek lehetnek a tudatelméleti müködés kulcsterületei. Vannak, akik az orbitofrontális kérget jelölik meg a tudatelmélet fő agyi területeként (pl. Stone, 2000), míg mások (pl. Gallagher és Frith, 2003) az anterior paracinguláris kérget feltételezik a fö területnek, és az OFC-nek, illetve az amygdalának másodlagos szerepet szánnak a tudatelméleti funkcionálásban. Majd a központi szerepet már a mediális prefrontális kéregnek szánták (pl. Amodio és Frith, 2006), továbbá ezekkel a leírásokkal ellentétben mások elsősorban a posterior területek szerepét emelik ki, például a hamis vélekedés reprezentációja a jobb oldali temporo-parietális junkcióhoz (TPJ) köthető (pl. Saxe, 2006), a bal oldali TPJ a frontális lebenyhez csatlakozva a mentális állapotok reprezentációjáért felelős (pl. Samson és mtsai, 2004). Látva ugyanakkor az eltérő véleményeket, kevés próbálkozás mutat arra, hogy egy integrált hálózatba rendezzék ezeket a területeket (Abu-Akel és Shamay-Tsoory, 2011). A feltárt agyi területek nagy többsége a legtöbb idegrendszeri háttérrel foglalkozó 
kutatásban megjelenik, függetlenül a tudatelméleti feladatok típusától, illetve attól, hogy vizuális vagy verbális ingeranyag szerepel a feladatokban (Apperly, 2011).

A tudatelmélet fogalmának tárgyalásakor már ismertettük, hogy nem egységes konstruktumként tekinthetünk erre a képességre. Az affektív („hot”) és a kognitív („,cold”) tudatelméleti komponensek elkülönítését nem csak elméleti vagy viselkedéses szinten vizsgálták, hanem eltérő agyi hálózatokhoz igyekeztek kötni a két komponenst. Számos kutatás arra utal, hogy a prefrontális kérgen belül az affektív tudatelméleti müködés elsősorban az orbitofrontális kéreghez, a ventrális mediális prefrontális kéreghez, az inferior laterális frontális kéreghez és az amygdalához köthető (Abu-Akel és Shamay-Tsoory, 2011). A kognitív tudatelméleti müködés inkább a dorsalis mediális prefrontális kéreghez, a dorsalis lateralis prefrontális kéreghez köthető (Kalbe és mtsai, 2010). Ezen területeknek nincs, vagy nagyon kevés direkt anatómiai kapcsolata van a limbikus rendszerrel, illetve azokkal a területekkel, amelyek az érzelmi állapotok feldolgozásához köthetők. A tudatelmélet és az empátia viszonyát Shamay-Tsoory és munkatársai (2010) összefoglalása alapján ismertettük (1. 1.2. fejezet), ugyanakkor a neuroanatómiai háttér tekintetében két elkülönülö empátiás rendszert feltételezhetünk, egy érzelmi rendszert illetve egy kognitív rendszert. A kognitív empátia rendszerén belül a léziós vizsgálatok arra utalnak, hogy a ventrális mediális prefrontális kéreg sérülés elsősorban affektív tudatelméleti zavarát, vagyis a kognitív empátia nehézségét okozza, míg az affektív empátia az inferior frontális gyrus, az anterior cinguláris kéreg és az amygdala területeihez köthető (Dvash és Shamay-Tsoory, 2014). Ugyanakkor az anterior cinguláris kéreg, a temporális pólus és striatum valószínüleg az affektív és a kognitív tudatelméleti müködésben is részt vesz ( $\mathrm{Abu}$ - $\mathrm{Akel}$ és Shamay-Tsoory, 2011; Kalbe és mtsai, 2010). Az anterior cinguláris kéreg ventrális része elsősorban az önreflexió érzelmi aspektusáért felel, míg a dorsalis rész pedig a kognitív tudatelmélet folyamatában részt vevő terület (pl. Sommer és mtsai, 2007). A temporális pólus mind az affektív, mind a kognitív tudatelméleti feladatokban aktivitást mutat, azonban a dorsalis és a ventrális területek elkülönülését az affektív-kognitív differenciálásban még nem mutatták ki egyértelmüen, ugyanakkor a területek anatómiai kapcsolatai alapján feltételezhető a differenciáció (Abu-Akel és Shamay-Tsoory, 2011). A striatum dorsalis területét a kognitív, míg a ventrális területét az affektív folyamatokhoz köthetjük, így feltehetően a differenciált tudatelméleti komponensek is e területekhez köthetök. A striatummal kapcsolatos bizonyítékok a kognitív és az affektív tudatelmélet elkülönítésében a Parkinson-kórral diagnosztizált személyekkel végzett vizsgálatok alapján feltételezhetők (Bodden és mtsai, 2010; Poletti és 
mtsai, 2011). A reprezentáció elsőként a temporo-parietális junkcióban szerveződik, majd ezt követően közvetítődik az superior temporalis sulcuson vagy a precuneus/posterios cingularis kérgen keresztül a limbikus és paralimbikus régiókhoz, ahol megtörténik a reprezentáció affektív vagy kognitív töltetének megjelölése. A kognitív és affektív hálózatok kölcsönhatásában az anterior cinguláris kéreg játszik szerepet. A kognitív és affektív tudatelmélet hálózatának fentebb felvázolt föbb területeit a 2. ábrán mutatom be.

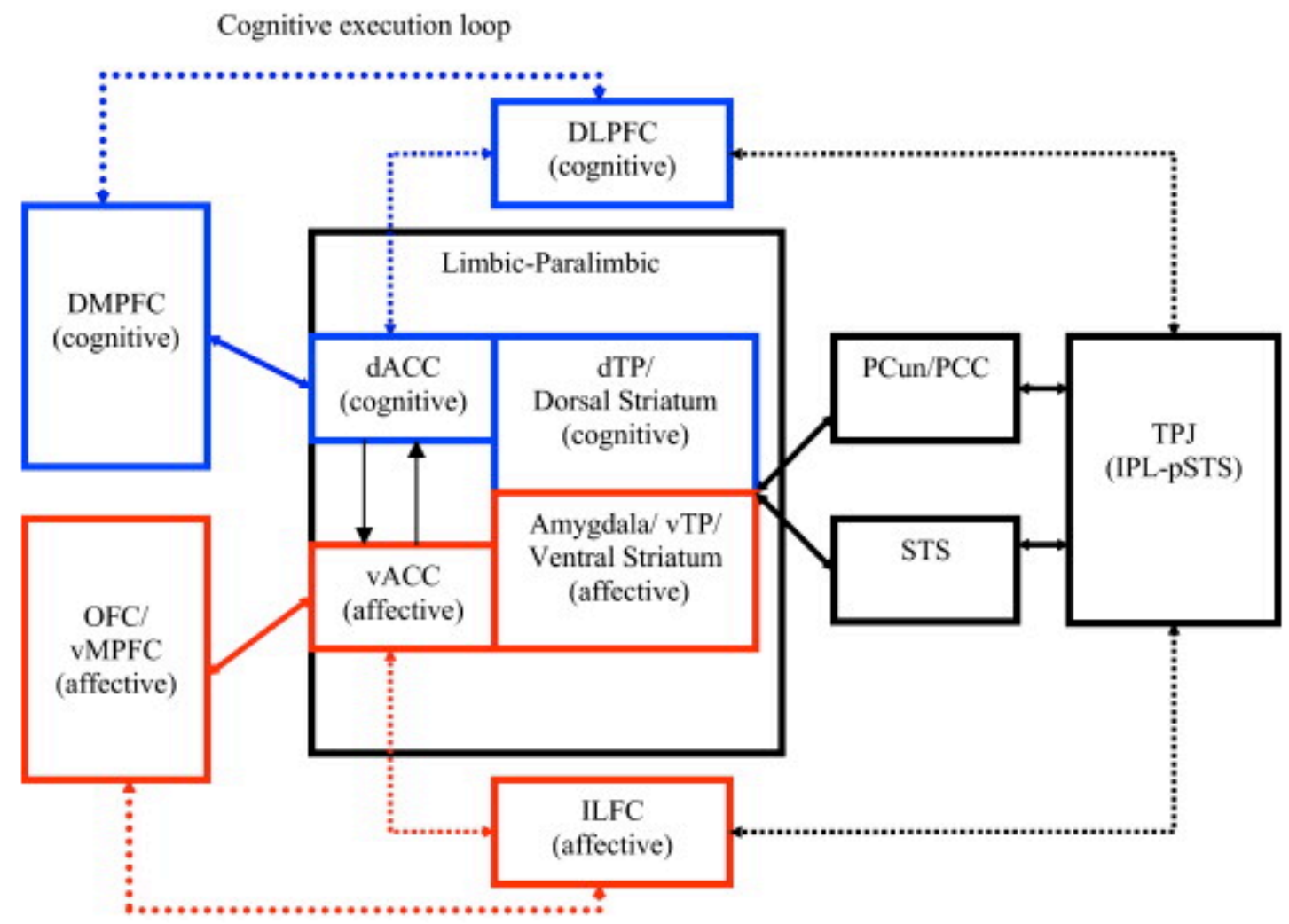

Affective execution loop

2. ábra: Az affektív és a kognitív tudatelméleti feldolgozáshoz kapcsolódó agyi területek Abu-Akel és Shamay-Tsoory (2011) által kialakított ábrán 2974. o. (A kék négyzetek a kognitív, a piros keretek az affektív tudatelméleti müködéshez tartozó területeket jelölik)

Az áttekintettek alapján tehát az affektív és a kognitív tudatelméleti elkülönítés a viselkedéses adatok mellett az agyi müködésben is tetten érhető, azaz eltérő agyi területekhez köthetők más személyek érzelmi állapotainak és a kognitív állapotainak feldolgozása ( $A b u$ - $A k e l$ és Shamay-Tsoory, 2011). A neurokémiai vizsgálatok azonban még pontosabb képet adhatnak a 
tudatelméleti müködésröl, mely szerint a dopamin-szerotonin rendszer mediálja a tudatelmélet müködését (Abu-Akel és Shamay-Tsoory, 2011).

Az affektív-kognitív tudatelméleti elkülönítés (Shamay-Tsoory és mtsai, 2007) mellett az interperszonális és intraperszonális tudatelméleti működés megkülönböztetése (Tine és Luciarello, 2012) is ismert viselkedéses szinten, neuroanatómiai korrelátumai is az érdeklődés középpontjában állnak. Az intraperszonális tudatelméleti müködésben a kérgi középvonali sturktúrák (mediális prefrontális kéreg, az anterior, a középső és a posterior cinguláris kéreg és a precuneus) felelősek az énnel kapcsolatos információk feldolgozásáért (Dvash és ShamayTsoory, 2014). Ugyanakkor a másokkal kapcsolatos információk feldolgozása inkább a dorsalis mediális prferontális kéreghez köthető, míg az énnel kapcsolatos információk feldolgozásában a ventrális mediális prferontális kéreg vesz részt (Denny, Kober, Wager és Ochsner, 2012). A kutatások és a metaanalízisek eredményei arra utalnak, hogy a mentalizációs hálózatban a ventrális mediális preferontális kéreg egy kulcsszerepet betöltő agyi terület, hiszen egyrészt felelős az én és a másik differenciációjáért, illetve affektív tudatelméleti működésért is, más agyi területekkel összhangban (Dvash és Shamay-Tsoory, 2014).

A tudatelmélet agyi hátterével foglalkozó kutatások elsősorban a neuronatómiai korrelátumokat tekintik át, azaz azokat az agyi területeket azonosítják, amelyek az elmeolvasás folyamatában fontos szerepet kapnak, vagyis az úgynevezett mentalizációs hálózatról adnak képet, emellett a neurokémiai vizsgálatokkal még teljesebb képet kaphatunk a tudatelméleti működés folyamatairól és esetleges zavarairól, illetve a zavarokban mutatkozó eltérésekről. Jelen disszertáció keretei között azonban nincs mód az egyes neurológiai és pszichiátriai zavarok során megjelenő tudatelméleti deficitek tárgyalására. Dolgozatom középpontjában a tudatelmélet tipikus fejlődésmenete és a kognitív funkciókkal való kapcsolata áll. Az agyi háttérrel foglalkozó kutatások elsősorban a frontális lebeny szerepe kapcsán jelentősek, hiszen a tudatelmélet és a kognitív funkciók (végrehajtó funkciók, munkamemória) müködésében is érintett terület a frontális lebeny, azaz a közös agyi háttér feltehetően a viselkedéses szinten is jelez kapcsolatot a két terület között (Carlson, Moses és Breton, 2002; Ragsdale és Foley, 2011). A továbbiakban a tudatelmélet mérési lehetőségeiről, tipikus fejlődéséről, illetve más funkciókkal való kapcsolatairól adunk áttekintést. 


\section{A TUDATELMÉLET MÉRÉSI LEHETŐSÉGEI}

A tudatelméletet mérő eljárások rendkívül változatosak, különböző életkortól, fejlödési vagy pszichiátriai, neurológiai zavartól függően alkalmazhatók (Baron-Cohen, 2001). A tudatelmélet zavarainak vizsgálatában mind a kognitív, mind az affektív tudatelméleti komponenst mérő eljárásokat, mind a komplex tudatelméleti teszteket alkalmazhatják. Az alábbiakban a leggyakrabban használt eljárásokat ismertetjük.

A tudatelmélet létezésének „bizonyítékaként” az úgynevezett hamis vélekedés megértését tekintik a kutatások, mely a gyermekkori fejlődésben körülbelül négyéves korban válik mérhetővé (Westby és Robinson, 2014). Az igaz vélekedés a valóság aktuális állapotán alapszik, a téves vélekedés azonban csak a másiknak a világ állapotáról alkotott mentális reprezentációja alapján érthető meg. A hamis vélekedés vizsgálatára kialakított módszerek közül a „váratlan áthelyezés” (Maxi csokija, Sally-Anne teszt; Wimmer és Perner, 1983) és a „váratlan tartalom” (Smarties-doboz, Hogrefe, Wimmer és Perner, 1986) a leginkább alkalmazott tesztek (Bíró, 2002). A váratlan áthelyezés feladatban (Wimmer és Perner, 1983) a szereplő távollétében áthelyez a vizsgálatvezető egy tárgyat egy új helyre, a visszajövő szereplő mentális állapotának a megértése a feladat. A váratlan tartalom feladatban (Hogrefe, Wimmer és Perner, 1986) egy ismert dobozban a várttól eltérő tartalom van (pl. cukorkás dobozban ceruzák), egy nem jelenlévő személynek a doboz tartalmáról alkotott reprezentációjára kíváncsi a feladat.

Ezek az ismertetett eljárások elsőfokú hamis vélekedés megértést kívánnak meg a vizsgálati személytől, elsősorban a kognitív tudatelmélet mérésére alkalmazzák. A másodfokú hamis vélekedés megértése a beágyazott mentális állapotok megértésén alapszik, vagyis egy személy gondolatainak kikövetkeztetése egy másik személy gondolatairól, mely 6 éves mentális kornak megfelelő fejlettségi szintet jelent (1. Baron-Cohen, 1989; Stefanik, 2005; Westby és Robinson, 2014).

Fejlettebb tudatelméleti működést kívánnak meg a szarkazmust, humort, iróniát és metaforát tartalmazó feladatok, vagy a blöffre, dupla blöffre épülő tesztek (például Strange Stories, Happé, 1994). Itt képpel kísért rövid történeteket követő kérdésekre kell válaszolnia a vizsgálati személynek, megértve az iróniát, blöfföt, viccet, füllentést. Ezt az eljárást elsősorban a kognitív tudatelmélet mérésére alkalmazzák. 
A komplex, fejlettebb tudatelméleti müködést megkívánó eljárások közé tartozik a Faux Pas Felismerése Teszt, melyet patológiás állapotokban, a tudatelméleti zavarok megállapítására számos klinikai kutatásban alkalmazzák (Stone, Baron-Cohen és Knight, 1998; Baron-Cohen, O’Riordan, Stone, Jones és Plaisted, 1999; magyarul 1. Gál, Egyed, Pászthy és Németh, 2011; Gál, Katona, Janacsek és Németh, 2014). A tesztben egy társas helyzetben történő elszólás, „faux pas” felismerése a cél. A faux pas megértésekor a vizsgálati személynek fel kell ismernie, hogy különbség van a beszélö, és az öt hallgató tudása között, valamint fel kell ismernie, hogy az elszólást negatív érzelem követte (Stone, Baron-Cohen, és Knight, 1998; Baron-Cohen és mtsai, 1999). A teszt ezek szerint tehát a kognitív és az affektív mentális állapotok megértését is méri. Egyrészt vizsgálja azt, hogy a faux pas egy téves vélekedés következménye (kognitív), illetve az elszólást negatív érzelem követi (affektív) (Stone, Baron-Cohen, Calder, Keane, és Young, 2003; Harari és mtsai, 2010). Mindezek alapján tehát a „faux pas” felismerése egy bonyolultabb mentális állapot tulajdonítást kíván meg, mely a gyermekkori tipikus fejlödésben 9-11 éves korban alakul ki (Baron-Cohen és mtsai, 1999). Az ilyen típusú feladatok jelentősége abban rejlik, hogy azok az esetlegesen zavart mutató csoportok, akik az egyszerübb tudatelméleti feladatokat sikeresen megoldják, a bonyolultabb mentális állapot tulajdonítás feladatokban már nem sikeresek, azaz a tudatelméleti zavar finom, hajszálnyi különbségeit is képesek feltárni (Varga, Tényi, Fekete és Herold, 2008; Gál, Egyed, Pászthy és Németh, 2011). Baron-Cohen és munkatársai (1999) vizsgálatában kimutatták, hogy a faux pas teljesítmény az életkor elöre haladtával nő a 7-11 éves tipikusan fejlődő gyermekek körében, továbbá a lányok kezdetben magasabb teljesítményt nyújtanak a teszten, azonban ez a különbség a gyermekek idősebbé válásával mérséklődik.

Egészséges gyermekek körében végzett vizsgálatukban Banerjee és Watling (2005), valamint Banerjee, Watling és Caputi (2011) kimutatták, hogy a gyermekek szociometriai pozíciója és a faux pas feladaton nyújtott teljesítménye között összefüggés van, longitudinális vizsgálati keretben is. Ez az összefüggés az idősebb gyermekek körében erősebb, illetve azoknál a gyermekeknél, akik alacsony szociometriai pozícióval rendelkeznek. Autizmusban és Asperger szindrómában végzett vizsgálatok arra mutatnak, hogy azok az autizmussal élő gyermekek, akik teljesítik az egyszerübb tudatelméleti feladatokat (első- és másodfokú hamis vélekedés tesztek), a faux pas feladatokban jóval alacsonyabb szinten funkcionálnak, mint a tipikusan fejlődő gyermekek (Baron-Cohen és mtsai, 1999). Neurológiai zavarokban hasonló eredményeket kaptak a kutatók arra vonatkozóan, hogy bizonyos neurológiai sérülésekkel rendelkező felnőttek 
alacsonyabban teljesítenek a faux pas feladatokban (ld. Gregory és mtsai, 2002 frontotemporális demenciában és Alzheimer-kórban végzett vizsgálatait; valamint Stone és mtsai, 2003 amygdala sérültekkel végzett, valamint Stone és mtsai 1998-as, frontális kéreg sérültekkel végzett vizsgálatait; Lee és mtsai, 2010 frontális léziós betegekkel végzett vizsgálatait, illetve Harari és mtsai, 2010 borderline személyiségzavarban végzett kutatását, Poletti, Enrici, Bonuccelli és Adenzato, 2011 Parkinson-kórban mutatkozó tudatelméleti problémákat összefoglaló tanulmányát). Pszichiátriai zavarok közül skizofréniában tudatelméleti problémákat mutatott ki a faux pas feladatokban Varga, Tényi, Fekete és Herold (2008) vizsgálata. Saját vizsgálati eredményeink pedig anorexia nervosá-ban igazolták az anorexiás serdülök faux pas teljesítményének alacsonyabb színvonalát, illetve a faux pas feladatokban mért affektív mentális állapot tulajdonítás zavarát az egészséges kontrollal összehasonlítva (Gál, Egyed, Pászthy és Németh, 2011), illetve bünelkövetőkkel végzett vizsgálatunkban a bünelkövető személyek és a kontrollszemélyek közötti különbségek kimutatásában is megfelelően alkalmazható eljárásnak bizonyult (Gál, Katona, Janacsek és Németh, 2014). Fontos megjegyezni tehát, hogy a teszt jó mérőeszköze a finom, hajszálnyi tudatelméleti deficiteknek és különbségeknek, emiatt jól alkalmazható klinikai és normál minta összehasonlításában, illetve tipikusan fejlődő gyermek szociális müködésének vizsgálatában is.

A Szociális Történetek Teszt (SSQ, Lawson, Baron-Cohen és Weelwright, 2004) elsősorban ennek az összetevőnek a mérésére kialakított mérőeszköz. Az SSQ a faux pas felismerését mérő tesztek továbbfejlesztett változata. A teszt 10 történetet tartalmaz, amiben egy szereplő olyan kijelentéseket tesz, mely felzaklathatja a történet másik szereplöjét. Enyhén és durván sértő, illetve sértő megjegyzést nem tartalmazó történeteket kell a vizsgálati személyeknek értékelniük aszerint, hogy (1) tartalmazott-e sértést, (2) illetve felzaklatta-e a történet másik szereplőjét (Lawson, Baron-Cohen és Weelwright, 2004).

Komplex, affektív és kognitív tudatelméleti komponenseket is mérő eljárás a Yoni-teszt (Shamay-Tsoory és Aharon-Peretz, 2007). Ezen a számítógépes teszten verbális információk és a tekintetirány alapján kell következtetni, hogy a képernyőn látható figura, Yoni mire vágyik, vagy mit szeret. A képernyő közepén Yoni feje található, illetve a képernyő négy sarkában négy kép. Yoni éppen a négy kép közül valamelyik irányba néz, ez az egyik kulcsingere a tesztnek, a másik pedig egy mondat, ami a szereplő vágyára, vélekedéseire vagy érzéseire utal (pl. Yoni szereti a...). A tesztkérdés vonatkozhat első vagy másodrendü, kognitív és affektív mentális állapottulajdonításra is, illetve tartalmaz egy kontroll feltételt is, ahol nem szükséges mentális 
állapotot tulajdonítani a feladat helyes megoldásához. A teszt az eredmények szerint megfelelöen alkalmazható a komplex tudatelméleti müködés feltárásában (pl. Shamay-Tsoory és AharonPeretz, 2007; Bodden és mtsai, 2010)

$\mathrm{Az}$ affektív tudatelmélet mérésére gyakran alkalmazott mérőeszköz a klinikai vizsgálatokban a Reading the Mind in the Eyes Test (Baron-Cohen, Jolliffe, Mortimore és Robertson, 1997; Baron-Cohen, Weelwright, Hill, Raste és Plumb, 2001), magyar változatát Szemekből Olvasás Teszt néven Ivády, Takács és Pléh (2007) munkájából ismerhetjük. A mérőeszköz a szem régiója alapján azt kívánja meg a vizsgálati személytől, hogy ítélje meg, melyik szó írja le legjobban a képen látható személy érzéseit. Mind a tipikus működésben (Baron-Cohen és mtsai, 2001; Gunther-Moor és mtsai, 2011), mind atipikus müködésben (pl. Baron-Cohen és mtsai 2001 autizmusban, Bodden és mtsai, 2010 és Poletti és mtsai, 2013 Parkinson-kórban) is jól alkalmazható eljárásnak bizonyult. Hasonlóan a Faces/Arcok Tesztben (Baron-Cohen, Weelwright és Jollife, 1997) is a vizsgálati személy feladata, hogy egy arc alapján ítélje meg, hogy a képen szereplő személy érzéseit melyik kifejezés írja le a leginkább.

A Short Stories Tesztet (magyarul Rövid Történetek Tesztet, Dodell-Feder és mtsai, 2013) több, általunk is fentebb említett tudatelméleti teszttel kapcsolatos tapasztalat alapján alakították ki. Céljuk egy könnyen és gyorsan felvehető eljárás, ami kerüli a plafonhatást és megfelelően megragadja az egyéni különbségeket, és valósághü szituációkra alapozva képes mérni a tudatelmélet különböző komponenseit a tipikus fejlődésű populációban is. A teszt során egy Hemingway novellát olvasnak a vizsgálati személyek (Valami véget ért, End of Something), melyet követően kérdéseket tesznek fel a vizsgálati személynek három területen: a történet megértésére, explicit mentális állapotok következtetésére (a szereplők vélekedéseire, érzelmeire, szándékaira és vágyaira vonatkozóan), illetve a spontán mentális állapot tulajdonításra vonatkozó kérdéseket. A vizsgálatok alapján a mérőeszköz a felnőtt populációban megfelelően alkalmazható tesztnek bizonyult (Dodell-Feder és mtsai, 2013).

A tudatelmélet több aspektusát térképezi fel egy Guttman-skálán a Tudatelmélet Fejlődési Skála (Theory of Mind Scale, Wellman és Liu, 2004) a tudatelmélet fejlődésének és egyéni különbségeinek feltárására kialakított mérőeszköz. Az eredeti változat hét feladatot tartalmazott, ugyanakkor az elemzések alapján öt skálából alakították ki a végleges változatot (Egyed és Nagy, 2014). Az öt feladat a következő: (1) eltérő vágyak (az embereknek eltérő vágyaik lehetnek az azonos dolgokkal kapcsolatban); (2) eltérő vélekedések (az embereknek eltérő vélekedéseik lehetnek az azonos szituációkkal kapcsolatban); (3) tudáshoz való hozzáférés 
(valami igaz lehet, de nem biztos, hogy ezt egy másik személy tudja); (4) hamis vélekedés (valami igaz lehet, de egy másik személy ezt hamisnak gondolhatja); (5) rejtett érzelmek (valaki egy bizonyos érzelmet él át, de egy másik érzelmet fejez ki), a feladatok ebben a nehézségi sorrendben követik egymást. A keresztmetszeti és longitudinális vizsgálatok is igazolták, hogy tipikus fejlődési gyermekek esetében, illetve atipikus fejlődés esetén is megfelelően alkalmazható eljárás (Wellman, Fang és Peterson, 2011). Az általunk ismertett tudatelméleti teszteket a 3. táblázatban foglaljuk össze.

3. táblázat: A széles körben alkalmazott tudatelméleti tesztek összefoglaló táblázata

\begin{tabular}{|c|c|c|c|}
\hline Teszt elnevezése & Szerző(k) & Populáció & Mért komponensek \\
\hline $\begin{array}{l}\text { Elsőfokú hamisvélekedés-teszt: } \\
\text { „váratlan áthelyezés” }\end{array}$ & $\begin{array}{c}\text { Wimmer és Perner } \\
(1983)\end{array}$ & $\begin{array}{l}\text { óvodáskor, tipikus és } \\
\text { atipikus fejlődés }\end{array}$ & hamis vélekedés megértése \\
\hline $\begin{array}{l}\text { Elsőfokú hamisvélekedés-teszt: } \\
\text { „váratlan tartalom” }\end{array}$ & $\begin{array}{l}\text { Hogrefe, Wimmer és } \\
\text { Perner (1986) }\end{array}$ & $\begin{array}{l}\text { óvodáskor, tipikus és } \\
\text { atipikus fejlődés }\end{array}$ & hamis vélekedés megértése \\
\hline $\begin{array}{ll}\text { Másodrendű } & \text { verbális } \\
\text { hamisvélekedés-teszt: } & \text { „Fagyis } \\
\text { történet” } & \\
\end{array}$ & $\begin{array}{l}\text { Baron-Cohen (1989) } \\
\text { Stefanik (2005) }\end{array}$ & $\begin{array}{l}6 \text { éves kortól, tipikus és } \\
\text { atipikus fejlődés }\end{array}$ & $\begin{array}{l}\text { beágyazott mentális } \\
\text { állapottulajdonítás }\end{array}$ \\
\hline Strange Stories & Happé (1994) & $\begin{array}{l}\text { iskoláskortól, tipikus és } \\
\text { atipikus müködés }\end{array}$ & $\begin{array}{l}\text { irónia, füllentés blöff, dupla } \\
\text { blöff megértése }\end{array}$ \\
\hline Faux Pas Felismerése Teszt & $\begin{array}{c}\text { Stone, Baron-Cohen, } \\
\text { és Knight (1998) } \\
\text { Baron-Cohen és mtsai } \\
\text { (1999) }\end{array}$ & $\begin{array}{l}\text { gyermek ( } 7-11 \text { év) és } \\
\text { felnőtt változat, tipikus } \\
\text { és atipikus müködés }\end{array}$ & $\begin{array}{l}\text { elszólások szándékának és } \\
\text { negatív érzelmi } \\
\text { következményeinek } \\
\text { megértése (kognitív és } \\
\text { affektív komponensek) }\end{array}$ \\
\hline $\begin{array}{lll}\begin{array}{l}\text { Szociális } \\
\text { (SSQ) }\end{array} & \text { Történetek } & \text { Teszt } \\
\end{array}$ & $\begin{array}{l}\text { Lawson, Baron-Cohen } \\
\text { és Weelwright (2004) }\end{array}$ & $\begin{array}{l}\text { tipikus és atipikus } \\
\text { múködés }\end{array}$ & $\begin{array}{l}\text { sértés azonosítása és } \\
\text { megértése }\end{array}$ \\
\hline „Yoni”-teszt & $\begin{array}{c}\text { Shamay-Tsoory és } \\
\text { Aharon-Peretz (2007) }\end{array}$ & $\begin{array}{l}\text { tipikus és atipikus } \\
\text { müködés }\end{array}$ & $\begin{array}{l}\text { első, másodrendü kognitív } \\
\text { és affektív mentális } \\
\text { állapottulajdonítás }\end{array}$ \\
\hline $\begin{array}{l}\text { Reading the Mind in the Eyes } \\
\text { Teszt } \\
\text { Faces Teszt }\end{array}$ & $\begin{array}{c}\text { Baron-Cohen, Jolliffe, } \\
\text { Mortimore és } \\
\text { Robertson (1997) } \\
\text { Baron-Cohen, } \\
\text { Weelwright, Hill, } \\
\text { Raste és Plumb, } \\
\text { (2001) } \\
\text { Baron-Cohen, } \\
\text { Weelwright és Jollife } \\
\text { (1997) }\end{array}$ & 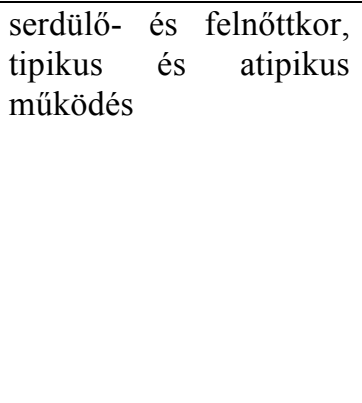 & $\begin{array}{l}\text { érzelmek tulajdonítása } \\
\text { szemek régiói és } \\
\text { arckifejezések alapján }\end{array}$ \\
\hline Short Stories Teszt & $\begin{array}{c}\text { Dodell-Feder és mtsai } \\
\text { (2013) }\end{array}$ & $\begin{array}{l}\text { tipikus és atipikus } \\
\text { müködés }\end{array}$ & $\begin{array}{l}\text { történet megértése, explicit } \\
\text { és spontán mentálisállapot } \\
\text { tulajdonítás }\end{array}$ \\
\hline Tudatelmélet Fejlödési Skála & Wellman és Liu (2004) & $\begin{array}{l}\text { gyermekkor, tipikus és } \\
\text { atipikus müködés }\end{array}$ & $\begin{array}{l}\text { eltérő vágyak, eltérő } \\
\text { vélekedések, tudáshoz való } \\
\text { hozzáférés, hamis } \\
\text { vélekedés, rejtett érzelmek } \\
\text { megértése }\end{array}$ \\
\hline
\end{tabular}


A fent leírt vizsgálati módszereket a teljesség igénye nélkül ismertettük, az általunk áttekintett kutatásokban az ismertett, elsősorban explicit eljárások gyakran szerepeltek a tudatelmélet, illetve egyes komponenseinek mérésére. Mindezeken túl további mérőeszközök is rendelkezésre állnak a tudatelmélet mérésére, akár az adott kutatásokban speciálisan kialakított eljárások is megjelennek, azonban ezek ismertetésére jelen disszertáció nem ad lehetőséget. Az áttekintés alapján megállapítható, hogy vannak olyan mérőeszközök, melyek mind a tipikus és atipikus fejlődés vizsgálatában jól alkalmazhatók (pl. első és másodfokú hamisvélekedés-tesztek, a Faux Pas Felismerése Teszt, a Szemekből Olvasás Teszt, a Tudatelmélet Fejlődési Skála, vagy éppen a Short Stories Teszt), ugyanakkor bizonyos eljárásokat (pl. „Yoni”-teszt) elsősorban atipikus müködés vizsgálatában alkalmazzák. Természetesen ez nem jelenti azt, hogy a tipikus, egészséges müködésben ne mérne megfelelően az eljárás. Ugyanakkor az áttekintett tesztek esetében akár tipikus, akár atipikus mintán alkalmazzuk őket, fontos kérdés, hogy milyen mértékben korrelál a való életben megfigyelhető viselkedéssel (pl. a szociális készségekkel) és milyen kognitív funkciók járulnak hozzá a tesztek sikeres megoldásához. Jelen disszertáció keretei között célunk elsősorban a külföldi és hazai kutatásokban mind a tipikus, mind az atipikus müködésben alkalmazott Faux Pas Felismerése Teszt magyar mintán történő kipróbálása, a kognitív funkciókkal és a társas hatékonysággal való kapcsolatának, illetve életkori különbségeinek feltárása. 


\section{A TUDATELMÉLET FEJLŐDÉSE, EGÉSZ ÉLETEN ÁT TARTÓ ÉLETKORI VÁLTOZÁSAI}

A tudatelmélet fejlődését régóta vizsgálják, az újabb kutatások rávilágítanak arra, hogy a tudatelmélet már a születéstől fogva folyamatosan fejlődő, illetve az életkor előrehaladtával változó képességnek tekinthető (Westby és Robinson, 2014). A korai csecsemőkori interakciók, vagyis a szülőkre irányuló figyelem, akik szemkontaktust vesznek fel a csecsemőikkel és beszélnek hozzájuk, az affektív tudatelmélet alapjait jelentik. Míg a kisgyermekkorban és az óvodás időszakban a gyerekek megértik, hogy ők másoktól elkülönülő egyének, és kifejlődnek azok a társas-kognitív és nyelvi készségeik, melyek segítségével megértik mások hamis vélekedéseit, azaz a kognitív tudatelmélet fejlődésének fontos tényezője (Westby és Robinson, 2014). A továbbiakban a tudatelmélet főbb fejlődési állomásait ismertetem a csecsemőkori előfutárokkal kapcsolatos vizsgálatoktól, a kisgyermekkori tudatelméleti müködésen át a serdülö-, felnőtt- és időskorban végzett kutatásokkal zárva a sort.

\subsection{A tudatelmélet csecsemökori prekurzorai}

A tudatelmélet fejlődési állomásainak prekurzorai már csecsemőkorban észlelhetők, a szülö és a csecsemő közötti interakciók kapcsán. Az elsődleges interszubjektivitás, azaz a szemtől szembeni interakciók, majd később másodlagos interszubjektivitás, vagyis a közös figyelmi viselkedés egy tárgy irányában (Gallagher és Hutto, 2008), az éntudat kialakulása, a tettetés/mintha-játék képessége, az érzelmek felismerése, illetve a mentális állapotokra vonatkozó szókincs kialakulása (Astington és Baird, 2005) mind a tudatelmélet csecsemőkori előzményeinek tekinthetők. Ebben a témakörben magyar kutatók számos vizsgálatot végeztek a csecsemőkori társas megismerés fejlődésével kapcsolatban (pl. a teljesség igénye nélkül: Bíró, 2002; Csibra, Bíró, Koós és Gergely, 2003; Gergely, Egyed és Király, 2007; Kovács, Téglás és Endress, 2010; Egyed, Király és Gergely, 2013). A vizsgálatok egy része a célok megértésére fókuszált csecsemőkorban, az eredmények szerint a 12 hónapos csecsemők már képesek a racionális cselekvés elve alapján teleológiai értelmezési keretet használni (Csibra és Gergely, 2002; Gergely és Csibra, 2005; Bíró, 2002). A teleológiai értelmezési keret azonban nem 
feltételezi a vélekedések vagy vágyak tulajdonítását, de lehetővé teszi célállapotok feltételezését, és ezek alapján történő viselkedésmagyarázatot (Gergely és Csibra, 2005). A hamisvélekedésmegértés kapcsán az újabb kutatások szerint már csecsemőkorban a hamis vélekedés korai megnyilvánulásai kimutathatók (Onishi és Baillargeon, 2005; Kovács, Téglás és Endress, 2010).

Brüne és Brüne-Cohrs (2006) összefoglaló tanulmánya szerint a csecsemők már hathónapos korban képesek az élő és élettelen tárgyak elkülönítésére, 9 hónapos korban célvezérelt cselekvéseket képesek észlelni. 12 hónapos korban a közös figyelem képessége alakul ki, 14-18 hónapos korban a tekintet követése jelenik meg egy tárgy irányába, illetve a csecsemő képes a vágy, a szándék mentális állapotát, illetve az érzelmek és a célok közötti oki kapcsolatot megérteni. 18-24 hónapos korban a valóság és képzelet között képesek differenciálni, a valós események reprezentációiról lekapcsolni a hipotetikus állapotok reprezentációit, és megjelenik a mintha-játék, melyet a tudatelmélet egy fontos előfutárának tekinthetünk. A kutatások szerint a négyéves korban megjelenő hamisvélekedés-tesztek megoldása előtt implicit tudatelmélet jelenik meg, amikor is a hamisvélekedés-tesztekben a hároméves gyerekek a verbális válaszuk előtt már a megfelelő helyre néznek, vagyis a fejlődésben korábban jelenik meg az implicit, mint az explicit tudatelmélet (Clements és Perner, 1994).

\subsection{A tudatelmélet gyermekkori fejlödésére vonatkozó elképzelések}

Brüne és Brüne-Cohrs (2006) áttekintése szerint a 3-4 éves korú gyermekek képesek megérteni a hamis vélekedést, azt, hogy egy személynek a valóságtól eltérő gondolatai vannak a világról, majd 5-6 éves korban a gyermekek megértik, hogy egy személynek lehetnek gondolatai egy másik személy gondolatairól (beágyazott mentális állapot tulajdonítás). A 6-7 éves korú gyermekeknél a metafora és irónia megértése alakul ki, mely azt a képességet kívánja meg a személytől, hogy megértse egy kijelentés nem szószerinti jelentését, továbbá ebben az életkorban képesek elkülöníteni a viccet a hazugságtól (Brüne és Brüne-Cohrs, 2006; Bíró, 2002). A 9-11 éves korú gyermekeknél a „faux pas” megértése jelenik meg, vagyis egy olyan, társas helyzetben véletlenül történt elszólás megértése, mely rossz érzést kelthetett másokban. A faux pas megértése már fejlettebb tudatelméletet igényel, hiszen két mentális állapot egyidejü megértését követeli meg: a faux pas-t elkövető személy perspektíváját, aki nincs tudatában elszólásának, illetve a másik személy perspektíváját, akit megbántott az elszólás (Baron-Cohen, O’Riordan, 
Stone, Jones és Plaisted, 1999). Annak ellenére, hogy rengeteg eredmény szól a gyermekkori tudatelmélet feltérképezéséről, kevés adatunk van arra vonatkozóan, hogyan alakul ez a képesség akár serdülőkorban, akár az egészséges felnőttek vonatkozásában. Feltételezhető, hogy a tudatelmélet folyamatos finomodásával számolhatunk felnőttkori fejlődés folyamán (Brüne és Brüne-Cohrs, 2006).

Mind az affektív, mind a kognitív tudatelmélet számos fejlődési állomáson megy keresztül. Az elsőfokú tudatelmélet négy és ötéves kor között alakul, ennek során más emberek gondolatainak vagy érzéseinek kikövetkeztetése történik. A másodfokú tudatelmélet körülbelül 7 éves korban fejlödik, ennek során a gyerekek képesek kikövetkeztetni egy személy gondolatait vagy érzéseit egy másik személy gondolatairól vagy érzéseiről. Majd a magasabb rendű kognitív és affektív tudatelméleti funkciók 8 és 12 éves kor között alakulnak ki, ezek kapcsán a gyerekek képesek felismerni a hazugságot, a szarkazmust, a figuratív nyelvtant, az idiómákat, illetve a többszörösen beágyazott mentális állapotokat (Westby és Robinson, 2014).

Westby és Robinson (2014) fejlődésre vonatkozó áttekintő tanulmányukban négy szintet különítettek el a tudatelmélet gyermekkori fejlődésében, mindezt a kognitív tudatelméleti (intraés interperszonális szinten) és az affektív tudatelméleti (intra- és interperszonális szinten) komponensekre vonatkoztatva. A következőkben ezt a modellt ismertetem, átfogó és átlátható összefoglalását adja e bonyolult képesség fejlődésének, az egyes életkorokban megjelenő szinteket, illetve a szintekhez tartozó készségeket a 4. táblázatban ismertetem. 
4. táblázat: A tudatelméleti komponensek megjelenése tipikus fejlődésmenetű gyermekeknél, a tudatelmélet szintek és azokhoz tartozó készségek

Westby és Robinson (2014, 366-368. o.) alapján

\begin{tabular}{|c|c|c|c|c|c|}
\hline \multirow{2}{*}{$\begin{array}{l}\text { Tudatelmélet } \\
\text { fejlödési szintjei }\end{array}$} & \multirow[t]{2}{*}{ Életkor } & \multicolumn{2}{|c|}{ Kognitív tudatelmélet } & \multicolumn{2}{|r|}{ Affektív tudatelmélet } \\
\hline & & Interperszonális kognitív & $\begin{array}{c}\text { Intraperszonális } \\
\text { kognitív }\end{array}$ & Interperszonális affektiv & Intraperszonális affektív \\
\hline \multirow{6}{*}{$\begin{array}{l}\text { Pretudatelmélet: } \\
\text { elsödleges és } \\
\text { másodlagis } \\
\text { interszubjektivitás }\end{array}$} & \multirow{2}{*}{$\begin{array}{l}\text { születéstől } \\
6 \text { hónapos } \\
\text { korig }\end{array}$} & \multicolumn{4}{|c|}{ elsődleges interszubjektivitás megjelenése } \\
\hline & & & & $\begin{array}{llr}\text { - } & \text { mások } & \text { érzelmi } \\
& \text { reakcióira } & \text { való } \\
& \text { reagálás } \\
\text { - } & \text { érzelmi fertőzés } \\
\end{array}$ & kifejezések utánzása \\
\hline & $\begin{array}{l}6-8 \\
\text { hónapos } \\
\text { kor } \\
\end{array}$ & $\begin{array}{l}\text { válaszkész közös figyelmi } \\
\text { viselkedés }\end{array}$ & & & a harag, öröm, undor és szomorúság kifejezése \\
\hline & \multirow{2}{*}{$\begin{array}{l}\text { 8-12 } \\
\text { hónapos } \\
\text { kor }\end{array}$} & \multicolumn{4}{|c|}{ másodlagos interszubjektivitás megjelenése } \\
\hline & & $\begin{array}{l}\text { követi a tekintet irányát } \\
\text { kezdeményezi a közös } \\
\text { figyelmi viselkedést egy } \\
\text { tárgy irányában }\end{array}$ & $\begin{array}{l}\text { viselkedészabályozás: } \\
\text { kezdeményezi a kért } \\
\text { viselkedést }\end{array}$ & $\begin{array}{lr}\text { a gondozók } & \text { érzelmi } \\
\text { kifejezéseit } & \text { szociális } \\
\text { referenciaként } & \text { alkalmazza } \\
\text { egy helyzet } & \text { megközelítése } \\
\text { vagy elkerülése érdekében }\end{array}$ & $\begin{array}{l}\text { a boldogság, a düh, a szomorúság, meglepettség, } \\
\text { undor és félelem kifejezése }\end{array}$ \\
\hline & $\begin{array}{l}\text { 13-17 } \\
\text { hónapos } \\
\text { kor }\end{array}$ & $\begin{array}{l}\text { megérti a fizikai kapcsolatot } \\
\text { más személyek tekintetiránya } \\
\text { és a viselkedésük között: a } \\
\text { személy azt látja, amire néz }\end{array}$ & & & $\begin{array}{l}\text { - közvetlen kapcsolat során törekszik mások } \\
\text { érzéseinek megváltoztatására } \\
\text { - interakciók koordinálása/közös szabályozása }\end{array}$ \\
\hline \multirow[t]{2}{*}{$\begin{array}{l}\text { Pretudatelmélet: } \\
\text { az éntudat } \\
\text { kialakulása }\end{array}$} & $\begin{array}{l}18 \text { hónapos } \\
\text { kortól } 2 \\
\text { éves korig }\end{array}$ & $\begin{array}{lr}\text { felismeri, hogy } & \text { különbözö } \\
\text { emberek különbözö dolgokat } \\
\text { szeretnek, } \\
\text { vágyaik vannak }\end{array}$ & $\begin{array}{ll}\text { - } & \text { kialakuló én-tudat } \\
\text { - } & \text { mintha-játékban } \\
& \text { elköteleződik }\end{array}$ & $\begin{array}{l}\text { tudatosan képes felismerni } \\
\text { a stresszt másokon, } \\
\text { bejósolja, hogy a törött } \\
\text { játékot kapva a gyerekek } \\
\text { szomorúak lesznek }\end{array}$ & $\begin{array}{l}\text { - } \begin{array}{l}\text { kialakuló altruista viselkedés: megvigasztal } \\
\text { másokat, igyekszik megváltozatni mások } \\
\text { vagy egy baba érzéseit úgy, hogy egy játékot } \\
\text { visz vigasztalásul } \\
\text { - használja a boldog, szomorú, dühös és } \\
\text { félelem szavakat }\end{array}\end{array}$ \\
\hline & 3 éves kor & $\begin{array}{l}\text { megérti, hogy az } \\
\text { emberek viselkedését } \\
\text { irányíthatják a vágyaik, }\end{array}$ & $\begin{array}{l}\text { - megérti, hogy a } \\
\text { képzeletbeli } \\
\text { tárgyak }\end{array}$ & \begin{tabular}{llr|} 
- & \multicolumn{3}{l}{ összekapcsolja } & a \\
boldog, & & szomorú, \\
dühös & és & félelem
\end{tabular} & $\begin{array}{ll}\text { - } & \text { beszél az érzelmek okairól és } \\
\text { következményeiről } & \\
\text { - } & \text { tárgyat és barátot alkalmaz az érzelmek }\end{array}$ \\
\hline
\end{tabular}




\begin{tabular}{|c|c|c|c|c|c|}
\hline & & 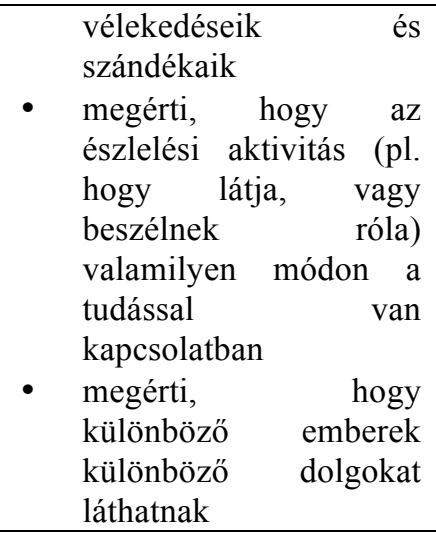 & $\begin{array}{l}\text { különböznek a } \\
\text { valós tárgyaktól } \\
\text { az emlékezni, } \\
\text { tudni és } \\
\text { gondolkodni } \\
\text { szavak } \\
\text { megjelennek a } \\
\text { spontán beszédben }\end{array}$ & $\begin{array}{l}\text { szavakat fotókon } \\
\text { látható arcokkal } \\
\text { sematikus } \\
\text { arckifejezéseket } \\
\text { felismeri } \\
\text { - ismeri azokat a } \\
\text { helyzeteket, amelyek } \\
\text { alapérzelmeket } \\
\text { váltanak ki }\end{array}$ & $\begin{array}{l}\text { változtatására } \\
\text { - kezdi kimutatni a tudatos érzelmeket: zavar, } \\
\text { büszkeség, szégyen, büntudat }\end{array}$ \\
\hline $\begin{array}{c}\text { Elsörendü } \\
\text { tudatelmélet }\end{array}$ & $\begin{array}{l}\text { 4-5 éves } \\
\text { kor }\end{array}$ & $\begin{array}{l}\text { elsőfokú } \quad \text { kognitív } \\
\text { tudatelmélet: bejósolja } \\
\text { mások gondolatait, érzéseit } \\
\text { - képes teljesíteni a } \\
\text { hamisvéledés-teszteket: } \\
\text { váratlan tartalom és } \\
\text { váratlan áthelyezés } \\
\text { típusúakat } \\
\text { képes bejósolni egy } \\
\text { másik személy } \\
\text { cselekvéseit a hamis } \\
\text { vélekedése alapján } \\
\text { perspektívaváltás: } \\
\text { nemcsak azt érti meg, } \\
\text { hogy mások mit látnak, } \\
\text { hanem hogy hogyan } \\
\text { jelenik meg ez } \\
\text { számukra }\end{array}$ & 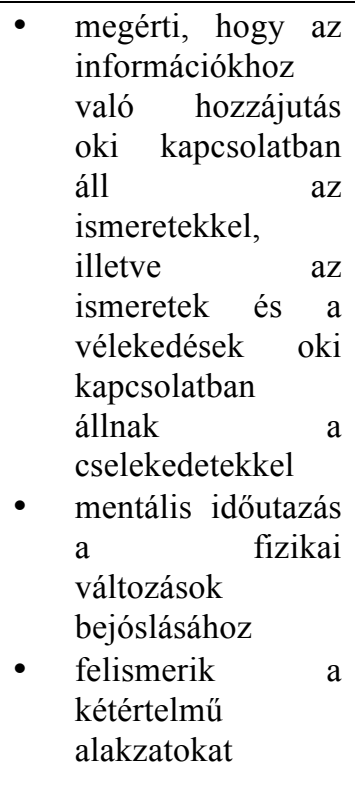 & 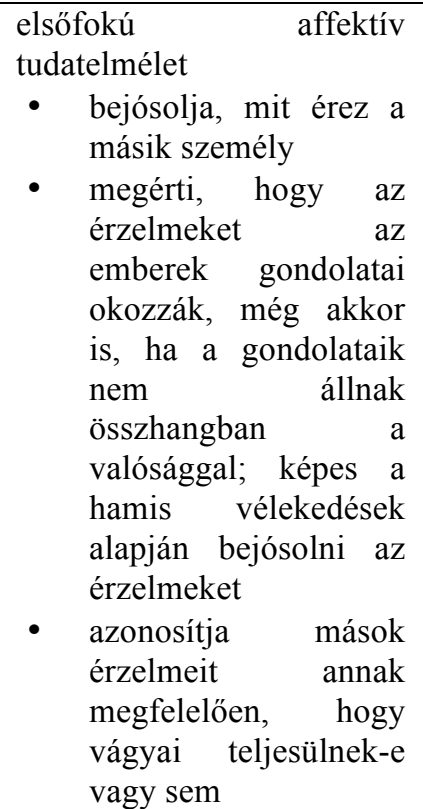 & 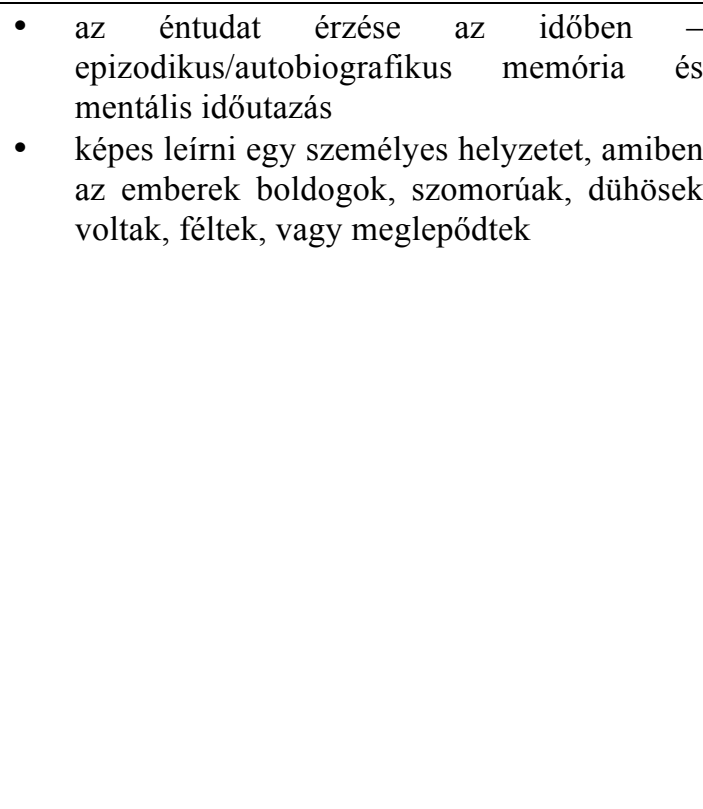 \\
\hline
\end{tabular}




\begin{tabular}{|c|c|c|c|c|c|}
\hline \multirow[t]{2}{*}{$\begin{array}{l}\text { Másodrendü és } \\
\text { magasabb rendü } \\
\text { tudatelmélet }\end{array}$} & \begin{tabular}{ll|}
$6-8$ & éves \\
kor & \\
\end{tabular} & $\begin{array}{l}\text { másodfokú kognitív } \\
\text { tudatelmélet: bejósolja, hogy } \\
\text { egy adott ember hogyan } \\
\text { vélekedik egy másik ember } \\
\text { gondolatairól } \\
\text { A úgy véli, hogy B úgy véli, } \\
\text { hogy... }\end{array}$ & $\begin{array}{l}\text { helyesen ítéli meg } \\
\text { azokat a helyzeteket, } \\
\text { amelyekben valaki tud, } \\
\text { emlékezik, felejt vagy } \\
\text { kitalál }\end{array}$ & 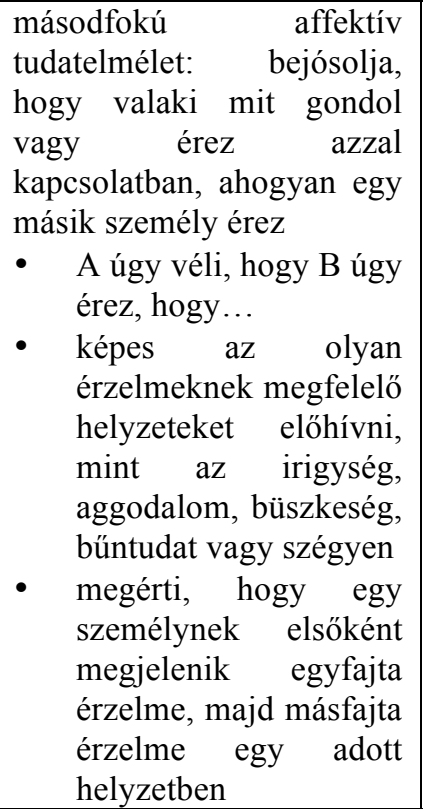 & $\begin{array}{l}\text { - olyan szavakat használ, mint irigység, } \\
\text { büszkeség, aggodalom } \\
\text { kialakít érzelemszabályozó stratégiákat }\end{array}$ \\
\hline & $\begin{array}{l}\text { 8-10 éves } \\
\text { kor }\end{array}$ & $\begin{array}{l}\text { magasabb rendü tudatelmélet } \\
\text { - megérti a stratégiákat, } \\
\text { melyekkel elrejthető } \\
\text { vagy felismerhető a } \\
\text { csalás } \\
\text { - érti a figuratív nyelvtant } \\
\text { - felismeri a kognitív } \\
\text { hazugságokat }\end{array}$ & $\begin{array}{l}\text { metakognitív } \\
\text { stratégiákat alkalmaz a } \\
\text { megértéshez vagy } \\
\text { megértés } \\
\text { monitorozásához }\end{array}$ & 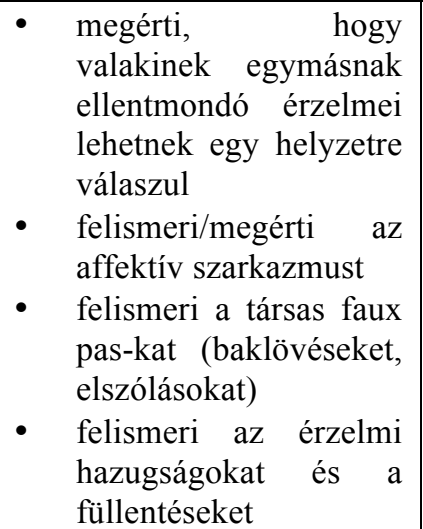 & $\begin{array}{l}\text { - } \quad \text { képes elrejteni az érzelmeket } \\
\text { - } \quad \text { szándékosan képes érzelmi arckifejezéseket } \\
\text { használni félrevezetés céljából } \\
\text { a megkönnyebbülés és a csalódottság szavak } \\
\text { - a korai serdülökorban jelennek meg } \\
\text { - alkalmazza a szarkazmust } \\
\text { alkalmazza az érzelmi hazugságokat és } \\
\text { füllentéseket } \\
\text { alkalmaz hazugságokat, hogy jobb színben } \\
\text { tüntesse fel saját magát mások szemében }\end{array}$ \\
\hline
\end{tabular}


Westby és Robinson (2014) áttekintésében tehát négy fejlődési szintet különített el a tudatelmélet gyermekkori fejlödésében:

I. Pretudatelmélet (elsődleges és másodlagos interszubjektivitás): születéstől 18 hónapos korig - ebben az időszakban jelenik meg az elsődleges interszubjektivitás és az érzelmek megosztása a csecsemők és a gondozóik között, illetve a csecsemők tükrözik gondozóik kifejezéseit, mindezek az alapjai az affektív tudatelméletnek.

II. Pretudatelmélet (éntudat kialakulása): 18 hónapos kortól 4 éves korig - ezen időszak elején alakul ki az éntudat és a mintha-játék. Az éntudat kialakulása következtében a gyerekek észlelik, hogy ők másoktól elkülönülő egyének, és másokétól különböző vágyaik lehetnek. Emellett az alturista viselkedés is megjelenik, szándékosan segítenek vagy vigasztalnak másokat. Továbbá 2 és 5 éves kor között a gyerekek megtanulják azonosítani az alapérzelmeket.

III. Elsőfokú tudatelmélet: ebben az időszakban képesek a gyerekek, kb. 4-5 éves korban már nagy biztonsággal megoldani a hamisvélekedés-teszteket, a váratlan áthelyezés (pl. Sally-Anne teszt) vagy váratlan tartalom (pl. Smarties) teszteket, a tesztek helyes megoldása nagyban függ a nyelvi készségektől. A hamisvélekedésmegértése az alapérzelmek, vagyis nem szociális érzelmek megértésétől a szociális érzelmek megértése felé mozdítja el a gyermekek fejlődését. A társas érzelmek már megkívánják a másik személy gondolatainak, vágyainak a reprezentációját.

IV. Másodrendủ és magasabb rendủ tudatelmélet: ebben az időszakban, 7 éves korban alakul ki a másodrendü tudatelmélet, majd ezt követően a magasabb rendű tudatelmélét, mely magában foglalja a beágyazott mentális állapotok megértését, valamint a szarkazmus, irónia, figuratív nyelvtan és a faux pas-k megértését is.

A tudatelmélet gyermekkori tipikus fejlődésével kapcsolatban tehát részletes ismereteink vannak, ugyanakkor a serdülőkori, felnőttkori és az időskori tudatelmélet rendelkezésünkre álló adatait is érdemes áttekinteni, hiszen a jelen disszertáció egyik célja a tudatelmélet életkori különbségeinek feltérképezése időskorig. 


\subsection{A tudatelmélet életkori változásai serdülö- és felnőttkorban}

A tudatelmélet kisgyermekkort követő fejlődésének tanulmányozása elsősorban idegtudományi kutatási eredményekhez köthető, hiszen azon agyi területek, melyek a mentalizációs hálózathoz tartoznak, mind strukturális, mind funkcionális változásokon mennek keresztül még a serdülökor folyamán (Blakemore, 2008; Blakemore, 2012). Jelen fejezetben néhány olyan kutatás kerül bemutatásra, ami az iskoláskort követő tudatelméleti fejlődéssel foglalkozik. Az alábbiakban ismertett vizsgálatok között is szerepelnek képalkotó eljárással végzett kutatások, azonban elsősorban a viselkedéses adatokra támaszkodva ismertetjük az életkori változásokat, mivel jelen disszertációban is a tudatelmélet viselkedéses mérésével és életkori különbségeivel foglalkozunk.

Dumontheil, Apperly és Blakemore (2010) öt korcsoportban végzett vizsgálatai szerint a tudatelmélet fejlődése még a késő serdülőkor és a felnőttkor között is megfigyelhető. Vagyis késő serdülőkorban is kimutatható teljesítményjavulás mások perspektívája megértésének képességében, azok után is, hogy a feladathoz szükséges munkamemória kapacitás és gátlókontroll elérte a felnőtt színvonalat. Javaslatuk szerint a kimutatott fejlődési mintázat a végrehajtó funkciók és a tudatelmélet közötti kölcsönhatás folyamatos érését is jelzi (Dumontheil, Apperly és Blakemore, 2010).

Gunther Moor és munkatársai (2011) az affektív tudatelmélet fejlődését (Szemekből Olvasás Teszt) és ehhez kapcsolódó agyi aktivitását (fMRI) vizsgálták 3 korcsoportban. Viselkedéses eredményeik szerint a legfiatalabb korcsoport, a 10-12 évesek is jóval a véletlen szintje fölött teljesítettek (legalább 60\%-os pontossággal), azaz a szemekröl történő érzelmek leolvasása, az affektív tudatelmélet, már ebben a korai életkorban kialakul. Eredményeik azonban a 14-16 évesek enyhe hanyatlását jelezte a 10-12 évesek csoportjához és a fiatal felnőttekhez képest (Gunther Moor és mtsai., 2011).

A kognitív tudatelmélet fejlődése megelőzi az affektív tudatelmélet fejlődését, vagyis amíg a gyerekek 6-7 éves korban képesek megérteni a másodfokú hamisvélekedéstulajdonítást, azaz megértik azt, hogy A személy megérti B személy vélekedését, addig az, hogy A személy megérti B érzéseit, például a faux pas elkövetése kapcsán csak később, 9-11 éves korra alakul ki (Sebastian és mtsai, 2012). Sebastian és munkatársai (2012) ezt 
viselkedéses (rajzolt figurákkal ábrázolt történetek, melyekben affektív, kognitív és fizikai oksági feltételt hoztak létre), illetve fMRI-adatokkal ellenőrizték serdülők és felnőttek összehasonlításában. A viselkedéses adatok alapján az affektív tudatelméleti feladatokon a serdülők több hibát vétettek, mint a felnőttek, holott ez az életkori különbség a kognitív tudatelméleti feladatokban és a fizikai, azaz mentális állapottulajdonítást nem igénylö, kontroll feladatokban nem volt szignifikáns. Mindez arra utal, hogy az affektív tudatelmélet fejlődést mutat a serdülőkor és a felnőttkor közötti időszakban (Sebastian és mtsai, 2012).

Az affektív tudatelmélet kapcsán fontos fejlődéslélektani eredmény, hogy meglepetés érzelmének megértése már 7-9 éves korban kezd fejlődni, míg a komplex érzelmek, például a faux pas érzelmi következményeinek megértése később, 9-11 éves korban jelenik meg (Ruffman és Keenan, 1996, idézi Vetter és mtsai., 2013). Vetter és munkatársai (2013) kutatásukban életszerü tudatelméleti feladatokon (Cambridge Mindreading Face-Voice Battery Faces alskálája nyomán) keresztül vizsgálták az affektív tudatelméleti komponens serdülő- és fiatal felnőttkori fejlődését, a végrehajtó funkciókkal összefüggésben. Vizsgálatuk eredményei azt mutatják, hogy az életkor és az affektív tudatelméleti teljesítmény erős összefüggésben áll egymással, még a végrehajtó funkciók és az általános kognitív képességek kontrollálását követően is. Továbbá az eredmények azt mutatják, hogy az affektív tudatelméleti komponens, és a végrehajtó funkciók közül a gátlás, a váltás és a frissítés képessége között szoros összefüggés áll fenn, a három végrehajtó funkció nagymértékben magyarázza a varianciát, különösen igaz ez a gátlás funkciójának esetében (Vetter és mtsai, 2013).

Altgassen és munkatársai (2014) serdülők és fiatal felnőttek csoportját vizsgálták tudatelméleti, végrehajtó funkciót és prospektív emlékezetet mérö feladatokon nyújtott teljesítményük alapján. Eredményeik szerint serdülőkorban a tudatelméleti működés és a váltás képessége bejósolja a prospektív emlékezeti müködést, ugyanakkor ez a hatás már a fiatal felnőttek esetében nem megfigyelhető. Az áttekintett eredmények alapján a tudatelméleti müködés egészen fiatal felnőttkorig fejlődik és változik.

A serdülőköri tudatelméleti müködésre vonatkozó, friss kutatási eredmények összefoglalását az 5. táblázatban ismertetjük. 
5. táblázat: A serdülőkori tudatelméleti müködés sajátosságainak áttekintése

\begin{tabular}{|c|c|c|c|c|}
\hline Szerzők & Vizsgált korosztály & $\begin{array}{c}\text { ToM mérésére szolgáló } \\
\text { eljárások }\end{array}$ & Mért ToM- komponensek & Főbb eredmények \\
\hline $\begin{array}{l}\text { Dumontheil, } \\
\text { Apperly és } \\
\text { Blakemore } \\
(2010)\end{array}$ & $\begin{array}{l}\text { Gyermek I: } 8,9 \text { év } \\
\text { Gyermek II: } 10,6 \text { év } \\
\text { Serdülö I: } 12,7 \quad \text { év } \\
\text { Serdülö II: } 15,3 \text { év } \\
\text { Felnőtt: } 22,8 \text { év }\end{array}$ & $\begin{array}{l}\text { Referenciális } \\
\text { kommunikációs feladat } \\
\text { (Keysar és mtsai, } 2000 \\
\text { alapján) }\end{array}$ & & $\begin{array}{l}\text { késő serdülőkorban } \\
\text { teljesítményjavulás más } \\
\text { megértésének képességében }\end{array}$ \\
\hline $\begin{array}{l}\text { Gunther } \\
\text { Moor és } \\
\text { munkatársai } \\
(2011)\end{array}$ & $\begin{array}{l}\text { Korai serdülö: } 10-12 \text { év } \\
\text { Serdülö: } 14-16 \text { év } \\
\text { Fiatal felnőtt: } 19-23 \text { év }\end{array}$ & $\begin{array}{l}\text { Szemekből Olvasás } \text { Teszt } \\
\text { adaptált változata }\end{array}$ & tudatelméleti & $\begin{array}{l}\text { az érzelmek és gondolatok szemek alapján történő } \\
\text { dekódolása már korai életkorban megjelenik }\end{array}$ \\
\hline $\begin{array}{l}\text { Sebastian és } \\
\text { munkatársai } \\
(2012)\end{array}$ & $\begin{array}{l}\text { Serdülö: } 14,8 \text { év } \\
\text { Felnőtt: } 28,88 \text { év }\end{array}$ & $\begin{array}{l}\text { rajzolt karakterek által } \\
\text { szemléltetett történetek } \\
\text { (Völlm, 2006 alapján) } \\
\end{array}$ & $\begin{array}{l}\text { affektív, kognitív } \\
\text { tudatelméleti komponens és } \\
\text { kontroll feltétel }\end{array}$ & $\begin{array}{l}\text { az affektív tudatelmélet még a serdülőkor és a felnőttkor } \\
\text { között is fejlődést mutat }\end{array}$ \\
\hline $\begin{array}{l}\text { Vetter és } \\
\text { munkatársai } \\
(2013)\end{array}$ & $\begin{array}{l}\text { Középiskolás/serdülő } \\
\text { Egyetemista/fiatal felnőtt } \\
(12,08-22,92 \text { év) }\end{array}$ & $\begin{array}{lr}\text { Cambridge } & \text { Mindreading } \\
\text { Face-Voice } & \text { Battery ,facial } \\
\text { skale” } & \end{array}$ & $\begin{array}{l}\text { affektív } \\
\text { komponens, } \\
\text { funkciók }\end{array}$ & $\begin{array}{l}\text { az életkor és az affektív tudatelméleti teljesítmény között } \\
\text { erős összefüggés } \\
\text { az affektív tudatelméleti komponens, és a végrehajtó } \\
\text { funkciók közül a gátlás, a váltás és a frissítés képessége } \\
\text { között szoros összefüggés }\end{array}$ \\
\hline $\begin{array}{l}\text { Altgassen és } \\
\text { munkatársai } \\
(2014)\end{array}$ & $\begin{array}{l}\text { Serdülö: } 13,55 \text { év } \\
\text { Fiatal felnőtt: } 19,44 \text { év }\end{array}$ & Story Comprehension Test & $\begin{array}{l}\text { tudatelméleti } \\
\text { végrehajtó } \\
\text { prospektív }\end{array}$ & $\begin{array}{l}\text { fiatal felnőttek tudatelméleti teljesítménye jobb, mint a } \\
\text { serdülőké } \\
\text { a váltás és a tudatelméleti serdülőkorban jelzi előre a } \\
\text { prospektív emlékezeti teljesítményt }\end{array}$ \\
\hline
\end{tabular}




\subsection{A tudatelmélet időskori vizsgálatai}

Az egészséges felnőttkori és időskori tudatelmélet vizsgálata is az utóbbi években az érdeklődés fókuszába került az egészséges idősödés kognitív változásaival párhuzamosan. Az alábbiakban néhány olyan vizsgálati eredményt mutatok be, melyekben az időskori tudatelméleti teljesítményt a felnőttkori tudatelméleti müködéssel vetik össze a kutatások. Képet kaphatunk ezáltal a mentális állapottulajdonítás tipikus felnőttkori fejlődéséről is.

Az egyik első, időskorral foglalkozó kutatás, Happé, Winner és Brownell (1998) tanulmánya arra mutat rá, hogy kevés vizsgálat született az óvodáskort követő tudatelméleti fejlődésről. Kutatásuk fő célja a mentális állapottulajdonítás kognitív folyamatainak más képességektől való esetleges függetlenségének feltárása volt. Vizsgálatukban egészséges idős emberek tudatelméleti teszten elért eredményeit vetettek össze két fiatalabb csoporttal. Eredményeik szerint az idős csoport (61-80 évesek) jobban teljesített a tudatelméletet mérö, pl. dubla blöfföt, füllentést, meggyözést tartalmazó történeteken, mint a fiatalabb csoportok (16-30 és 21-30 évesek). Eredményeik magyarázatára többféle indokot vetettek fel, elképzelhetőnek tartják, hogy az idősebb személyek jobban érdeklödnek, és motiváltabbak a szociális történetek iránt, mint a fiatalabbak. Mindezt pedig a bölcsességgel hozzák összefüggésbe, mivel a bölcsesség egyik kulcsa a szociális érzékenység, ehhez hozzájárul egyfajta pszichológiai tudás, előny. Fontosnak tartották megjegyezni, hogy míg idősebb korban a rövid távú memória hanyatlása jelentkezik, addig a szociális ingerek magyarázata, attribúciója megtartott, mely a tudatelmélet egy különálló képességét jelentheti, azonban innát modulok bebizonyítása még nem történt meg, így legvalószínübb magyarázat lehet az életen át ívelő fejlödésben a modularizáció folyamata a kognitív képességek szétválásának tekintetében (Happé, Winner és Brownell, 1998).

Happé és munkatársai (1998) következtetéseihez képest Maylor, Moulson, Muncer és Taylor (2002) azonban már más eredményekre jutottak. Első kísérletükben három vizsgálatát végezték, a fiatal (16-29 évesek) korosztályt két idős csoporttal hasonlították össze, a 65-74 évesekkel és a 75-89 évesekkel. A tudatelméletet olyan feltételben vizsgálták, ahol a történetek egyik felénél emlékezni kellett a konkrét információra, a másik részben pedig nem. Eredményeik szerint a tudatelméleti teljesítmény hanyatlik az életkor elörehaladtával, az idősebb és fiatalabb idősek is rosszabbul teljesítettek a tudatelméleti feladaton a memória 
terhelés feltételében, míg a memória terhelés hiányában a fiatalabb idősek teljesítménye javult. Második kísérletükben azonban Happé, Winner és Brownell (1998) vizsgálatának precízebb megismétlését tervezték. Ebben a kísérletben az általános kognitív teljesítmény és a tudatelmélet mérése mellett a végrehajtó funkciókat is vizsgálták a Wisconsin Kártyaszortírozási feladat segítségével. A második kísérletben a fiatalok csoportját (18-27 évesek) hasonlították össze az idős korosztállyal (75-91 évesek). Eredményeik azt mutatják, hogy a fiatalok jobban teljesítettek az időseknél minden típusú tudatelméleti feladatban. Azaz Maylor, Moulson, Muncer és Taylor (2002) mindkét vizsgálatukban a tudatelméleti teljesítmény hanyatlását mutatták ki az idősebb korosztályban a fiatalokhoz képest. Vizsgálataik szerint a tudatelméleti teljesítmény romlása nem magyarázható egyértelmủen az általános kognitív képességek és a végrehajtó funkciók hanyatlásával idős korban. Wang és $S u$ (2006) a Faux Pas és a Strange Stories Tesztekkel hasonlította össze az idősek és a fiatal felnőttek tudatelméleti teljesítményét. Míg a faux pas megértésében az idősebbek rosszabbul teljesítettek, a Strange Stories teszteken nem találtak életkori különbséget, azonban egyik tudatelméletet mérő teszt sem állt összefüggésben a fluid intelligenciával, a teljes teszten mért intelligenciakvócienssel és a verbális, illetve a preformációs kvócienssel. Duval, Piolino, Bejanin, Eustache és Desgranges (2010) három korcsoportot hasonlítottak össze, a fiatalok, a középkorúak és az idősek korosztályát. A tudatelméleti teljesítményt szubjektív és objektív módon mérték. Az objektív tudatelméleti mérésben a kognitív (szándéktulajdonítás és hamisvélekedés-megértés) és affektív komponenseket (Szemekből Olvasás Teszt) is feltérképezték. Továbbá egy komplex tudatelméleti eljárást is alkalmaztak, mely mind az affektív, mind a kognitív komponens mérést lehetővé tette („Tom ízlése” - módszertanában hasonló a 2. fejezetben ismertetett „Yoni”-teszthez). A kognitív funkciókat egy neuropszichológiai tesztbattériával mérték, amelyben a gátlás, váltás és frissítés alapvető végrehajtó funkciókat vizsgálták. A tudatelmélet szubjektív megítélésében nem találtak szignifikáns életkori különbségeket, azonban az objektív, sztenderdizált tesztekkel kapott adatokban eltéréseket észleltek, az eltérések mögött más kognitív funkciókat feltételeznek. A kognitív tudatelméleti komponenst mérő teszteken az idősebb életkorokban szignifikánsan alacsonyabb tudatelméleti teljesítményt mértek a fiatalokéhoz képest. A végrehajtó funkciók müködése volt a legjobb előrejelzője a kognitív tudatelméleti teszteken nyújtott teljesítménynek, így valószínűsíthető, hogy az idős személyek kognitív tudatelméleti alacsonyabb teljesítménye az exekutív funkciók alacsonyabb szintjével áll összefüggésben. 
Az affektív tudatelméleti teszten az alapérzelmek kapcsán nem találtak eltérést az életkori csoportok között, azonban a komplex érzelmek tulajdonításában a középkorúak, és az idősek is rosszabbul teljesítettek a fiatal csoporthoz képest, ugyanakkor a mért kognitív funkciók egyike sem magyarázza ezt a különbséget a komplex érzelmek megértésében. Ez a mintázat a komplex tudatelméleti mérőeljárás tekintetében is megismétlődött, az életkor volt a legfontosabb bejóslója a teszten elért teljesítménynek.

Bernstein, Thorton és Sommerville (2011) tanulmányukban szintén időskorú, középkorú és fiatal felnőttek teljesítményét hasonlították össze tudatelméleti (hamisvélekedés-tesztet alkalmazva) és kognitív képességeiket mérő teszteken. Eredményeik szerint a középkorú és az idősebb vizsgálati személyek több hibát vétenek a hamisvélekedéstesztben a fiatal felnőttekhez képest, ezek a különbségek azonban nem magyarázhatók a kognitív funkciók életkori változásaival, vagyis függetlenek a nyelvi képességektől, a végrehajtó funkciótól, a feldolgozási sebességtől és a memóriától. Henry, Philips, Ruffman és Bailey (2013) meta-analízisében többféle tudatelméleti teszten, a komponensek szerint (affektív, kognitív, kevert) csoportosítva, többféle modalitásban tekintették át az idősek teljesítményét. Az idősek alacsonyabb színvonalon teljesítenek a tudatelméleti feladatokon a fiatalabbakhoz képest, függetlenül a teszt típusától, a komponensektől illetve a tesztek modalitásától. Moran (2013) áttekintő tanulmányában a képalkotó eljárásokkal végzett vizsgálatok eredményeit is áttekinti a viselkedéses adatok mellett, melyek hiánypótlóak lehetnek a tudatelmélet életkori változásait, egész életen át tartó vizsgálatai tekintve. Funkcionális MRI vizsgálatok arra az eredményre jutottak, hogy a Szemekből Olvasás Tesztet alkalmazva az idős és a fiatal korosztálynál is a jobb inferior frontális gyrus (IFG) aktivitása regisztrálható. A feladatvégzés közben az idős korosztálynál megfigyelhető volt a bal inferior frontális gyrus (IFG) aktivitása is, mely terület nem elsősorban mentalizációért felelős, sokkal inkább a verbális memóriával, illetve az alternatív válaszlehetőségek közötti választás funkcióival hozzák összefüggésbe (Castelli és mtsai, 2010). Az értelmezés szerint ez az bal IFG aktivitás feltehetően a mentalizációs nehézségek egy kompenzációs mechanizmusa, melyet a viselkedéses adatok is alátámasztanak, miszerint a jobb verbális képességek megelőzhetik a tudatelméleti nehézségeket időskorban (Moran, 2013). A fiataloknál pedig az anterior cinguláris kéreg (ACC) aktivitását regisztrálták, mely a mentalizációs hálózat része, ez az aktivitás azonban kevésbé volt regisztrálható időseknél, melyből arra következtetnek, 
hogy a területspecifikus tudatelméleti képesség nehézségeit az általános kognitív funkciók mozgósításával igyekeznek kompenzálni az idős személyek.

Moran (2013) tanulmányában áttekinti az idősekkel végzett tudatelméleti vizsgálatok legfontosabb eredményeit. Egy fontos megválaszolandó kérdésnek azt tekinti, vajon a tudatelmélet hogyan kapcsolódik össze más kognitív funkciókkal időskorban. A tanulmány rávilágít arra, hogy az idősek tudatelméleti teljesítményének vizsgálata nemcsak amiatt érdekes, hogy időskorban a tudatelméleti teljesítmény romlik, hanem amiatt is, hogy más kognitív képességektől függetlenül vagy éppen azokkal együtt változik a tudatelmélet időskorban, és ennek függvényében hogyan állapítható meg a tudatelmélet hanyatlása. Ha tehát a hanyatlás más kognitív funkcióktól függetlenül történik, akkor fontos kérdés az, hogyan állítható meg ez a hanyatlás, milyen fejlesztési módok és lehetőségek állhatnak rendelkezésünkre időskorban - például újratanítani az idősek számára a szociális kommunikáció finom jelzéseit, ez különösen fontos feladat az idegen emberekkel való interakciókban, akiknek a szándékai nem mindig nyilvánvalóak. Továbbá ha a tudatelmélet más funkciókkal együtt hanyatlik időskorban, ez esetben nagyobb figyelmet érdemes szentelni ezekre a funkciókra, így feltehetően az idősek társas képességei is megőrizhetők lesznek. Az időskori kutatások továbbá választ adhatnak arra a kérdésre, vajon a tudatelmélet egy modul, vagy éppen más kognitív működésekkel párhuzamosan változik. Mindezek mellett az időskori kutatások rávilágítanak arra, hogy a tudatelméleti tesztek közül a klasszikus, verbális alapú tesztek valamelyest építenek a kognitív képességeinkre, a munkamemóriára, a végrehajtó funkciókra és a feldolgozási sebességre. Míg a vizuális ingeranyagot alkalmazó mérőeljárásokkal végzett vizsgálatokban (hiszen olyan fluid képességeket nem vesz igénybe, melyek a szövegértéshez szükségesek) sokkal inkább az általános kognitív funkcióktól független képességként jelenik meg a tudatelméleti müködés. Érdekes módszertani kérdés ugyanakkor, hogy a másodrendü tudatelméleti tesztek esetében is megjelenik egyfajta függetlenség az általános kognitív képességektől. Újabb mérési módszerek alkalmazásával talán pont tehető annak a kérdésnek a végére, hogy vajon a tudatelmélet önálló, független modulként (Theory of Mind Module ToMM) müködik-e a kognitív struktúrában (Moran, 2013).

Saját vizsgálataink célja egyrészt az életkori különbségek feltárása, így az időskori változások feltérképezése, másrészt a tudatelmélet kognitív funkciókkal való kapcsolata kapcsán érdekes lehet Moran (2013) felvetése, miszerint a kognitív funkcióktól függetlenül, 
vagy azokkal együtt jelenik meg az időskori teljesítményromlás, hiszen ez nemcsak a módszertani, hanem a fejlesztési feladatok kapcsán is megválaszolandó kérdés.

\subsection{A tudatelmélet fejlödésével kapcsolatos elméleti alapvetések}

A tudatelmélet fejlődésével kapcsolatban számos elméleti megközelítés létezik. Az elméletek arra vállalkoznak, hogy magyarázatot adjanak azokra a klasszikus fejlődési kérdésekre, hogy például míg a 3 éves gyermekek nagy százaléka nem képes megoldani a hamisvélekedés-teszteket (pl. Sally-Anne vagy Smarties tesztek), addig a 4 éves gyerekek nagy százaléka már hiba nélkül képes ezeket teljesíteni. E fejlődési kérdés magyarázatában az alábbiakban a teljesség igénye nélkül a következő három elméleti megközelítést tekintem át: 1) Elmélet-Elmélet megközelítés (Gopnik és Wellmann, 1992) 2) a szimulációs modell (Harris, 1992), 3) nativista-moduláris megközelítés (Baron-Cohen, 1997).

Elmélet-elmélet megközelités - ez a megközelítés azt feltételezi, hogy a gyermek naiv elméletekkel rendelkezik a saját és mások pszichológiai állapotára vonatkozóan (Gopnik és Wellmann, 1992; Bíró, 2002; Kiss, 2005). Fő képviselője Gopnik, aki munkatársaival alakította ki azt az elképzelést, miszerint a gyerekek gondolkodási folyamatai nagyon hasonlóak a tudományos tudáshoz, kognitív fejlődésük pedig hasonlatos a tudomány fejlődéséhez. Ezen elmélet szerint a kognitív fejlődés egy elméletalkotási folyamatként definiálható, ebben a folyamatban a korábbi elméletnek ellentmondó bizonyítékok kapcsán elsőként új hipotéziseket alakítunk és illesztünk az elmélethez, majd ezen hipotézisekből egy új elméletet állítunk fel (Gopnik és Meltzoff, 1996). Az elképzelés szerint létezik egy velünk született elmélet, ezzel kezdődik meg az elméletalkotási folyamat. A mentális állapotok tulajdonítása ezen elmélet szerint a következő fejlődési folyamaton megy keresztül: csecsemőkorban, a születéstől körülbelül 2 és fél éves korig a „vágy és percepció” szakasza figyelhető meg, ahol a vágy azt a korai tudást jelképezi, hogy az elme tartalma megváltoztathatja azt, ami a világban történik, a percepció pedig egy arra vonatkozó korai tudás, hogy az elme tartalma attól függ, ami a világban van. Ezek a korai tudások azonban nem reprezentációra épülnek, csecsemőkori bizonyítékai pedig az elsődleges interszubjektivitás, a közös figyelmi viselkedés, illetve a szociális referencia. 2 és fél és 4-5 
éves kor között a vélekedés megértése még nem reprezentációs természetü, ugyanakkor 3 éves kor körül a gyerekek elkezdik használni a mentális állapotokkal kapcsolatos kifejezéseket. Majd 4-5 éves kor körül kialakul az „elme reprezentációs modellje”, amikor is a kialakult reprezentációk befolyásolják a legtöbb pszichológiai funkciót (Ferenczi, 2009). Bartsch és Wellmann (1995) szintén az elmélet-elmélet megközelítéséhez tartozó elképzelése szerint a tudatelmélet fejlődése három szakaszon keresztül megy végbe:

1. korai vágy pszichológia szakasza: a gyerekek széleskörủen használják a vágyakra vonatkozó kifejezéseket, megkülönböztetik saját és más személyek vágyait

2. vágy-vélekedés pszichológia szakasza: a vágyak mellett a vélekedésekről, és hamis vélekedésekről való beszélgetések is megjelennek 3 éves kor körül, ugyanakkor a viselkedésmagyarázatok során még a vágyak dominálnak

3. vélekedés-vágy pszichológia szakasza: a viselkedések magyarázataként a vélekedéseket veszik figyelembe és használják, 4 éves kor körül (Ferenczi, 2009; Kiss, 2005, Bíró, 2002).

Az elmélet-elmélet megközelítése szerint a fiatalabb gyerekek azért nem tudják teljesíteni a hamisvélekedés-tesztet, mert még nem rendelkeznek a vélekedésre vonatkozó mentális fogalommal és elmélettel (Kiss és Jakab, 2010).

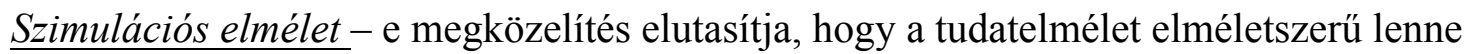
(Harris, 1992). A szimulációs elmélet fókuszában az áll, hogy más személyek mentális állapotaihoz úgy férhetünk hozzá, hogy szimuláljuk azokat. Vagyis úgy véli, hogy mivel saját tudatunkat közvetlenül elérjük, így más személyek mentális állapotainak megértésekor saját élményeink alapján szimuláljuk, hogyan éreznénk vagy gondolkodnánk a másik helyében az adott helyzetben (Bíró, 2002). Mindez azt jelenti, hogy mások mentális állapotait úgy reprezentáljuk, hogy szimuláljuk őket (Ferenczi, 2009). A szimulációs elképzelés fó képviselője, Harris (1992) szerint a szimulációs képesség kialakulásában kulcsfontosságú, hogy a gyermekek kétéves kor körül kezdik megérteni, hogy az érzések, vélekedések a világ tárgyaira, vagy dolgaira vonatkoznak, így képesek lesznek szimulálni más személyeknek a világ tárgyaira vonatkozó mentális állapotait. A tudatelméleti képességben megjelenő későbbi változások a gyermekek képzeleti képességének növekedésének, pontosabbá válásának függvénye (Bíró, 2002). 
Nativista/modularista elképzelés - ez a megközelítés elsősorban a tudatelmélet veleszületett tényezőit állítja fókuszba, és a szimulációs elkézleléshez hasonlóan, elvetik az elméletképzés és a hipotézisalkotás szerepét a tudatelmélet fejlődésében (Leslie, 1987; BaronCohen, 1997). Az elmélet képviselői úgy vélik, hogy a tudatelmélet egy innát, veleszületett feldolgozó mechanizmus, melynek müködése érés következtében indul be. Ez a velünk született mechanizmus a ToMM, vagyis a Theory of Mind Mechanism, ami a mentális állapotok reprezentációs természetét, vagyis Leslie megközelítése értelmében a metareprezentációt teszi lehetővé. A metareprezentációs képességet a mintha-játék megjelenése jelzi 18-24 hónapos korban Leslie (1987) szerint, vagyis a tudatelmélet már 24 hónapos korban müködő képesség, és 3 és 4 éves kor közötti fejlődése nem elméletváltásnak, hanem a gyermek információfeldolgozó kapacitása növekedésének, fejlődésének köszönhető. Simon Baron-Cohen (1997), aki a modularista elképzelés egyik fő képviselője, négy modult, komponenst feltételez, melyek egymástól függetlenül müködnek, hierarchikusan egymásra épülnek, egy tudatolvasó rendszert kialakítva. Az első komponens az Intencionalitás Detektor (Intentionality Detector - ID), amely elsősorban egy perceptuális mechanizmus, ami a mozgásos ingereket a primitív mentális állapotok, a vágyak és célok szempontjából értékeli. Az ID akkor aktiválódik, ha van olyan perceptuális inger (pl. önindította mozgás), ami feltehetően egy ágenst jelöl, azonban ha rájövünk, hogy az adott tárgy nem egy ágens, akkor felülvizsgáljuk az eredeti álláspontunkat. A következő komponens a Szemirány Detektor (Eye Direction Detector - EDD), elsősorban a szem típusú ingereket dolgozza fel, illetve azokat a diadikus kapcsolatokat reprezentálja, amelyek a nézés irányára vonatkoznak. A modularista elképzelés harmadik összetevője a Közös Figyelem Mechanizmusának Modulja (Shared Attention Mechanism - SAM), mely az ID és az EDD összekapcsolásával triadikus reprezentációkat alakít, vagyis a nézés irányából képes kiolvasni az adott ágens vágyát és célját. A modell legmagasabb szintű komponense a Tudatelméleti Mechanizmus modulja (Theory of Mind Mechanism - ToMM), mely a mentális állapotok teljes skáláját reprezentálja, és egy koherens modellbe rendezi. A ToMM aktiválódásához szükséges, de nem elégséges a SAM modul müködése, azaz a triadikus reprezentációk megjelenése. A modellben a közös figyelmi mechanizmus egy fontos csecsemőkori előzménye a tudatelmélet müködésének (Baron-Cohen, 1997; Bíró, 2002).

A modularista elképzelések egyik bizonyítékaként tekintik, hogy autizmusban a mintha-játék zavara, illetve a hamisvélekedés-tesztek megoldásában jelentkező deficitek, a 
társas funkcionálásban jelentkező zavarok (pl. szemkontaktus hiánya) is bizonyítékul szolgálhatnak a tudatelméleti modul hiányára vagy sérülésére (Baron-Cohen, Leslie és Frith, 1985), ezen keresztül arra is, hogy feltehetően egy különálló tudatelméleti modul létezik, ez felelős

az elmeolvasás

müködéséért

(Baron-Cohen,

1997).

Mivel a tudatelmélet modularista elképzelése sem magyarázza kizárólagosan az autizmus tüneteit, így ez a megközeltés nem vált egyetlen, a tudatelméletet magyarázó elméleti elképzeléssé (Bíró, 2002). A modellt a 3. ábra szemlélteti.

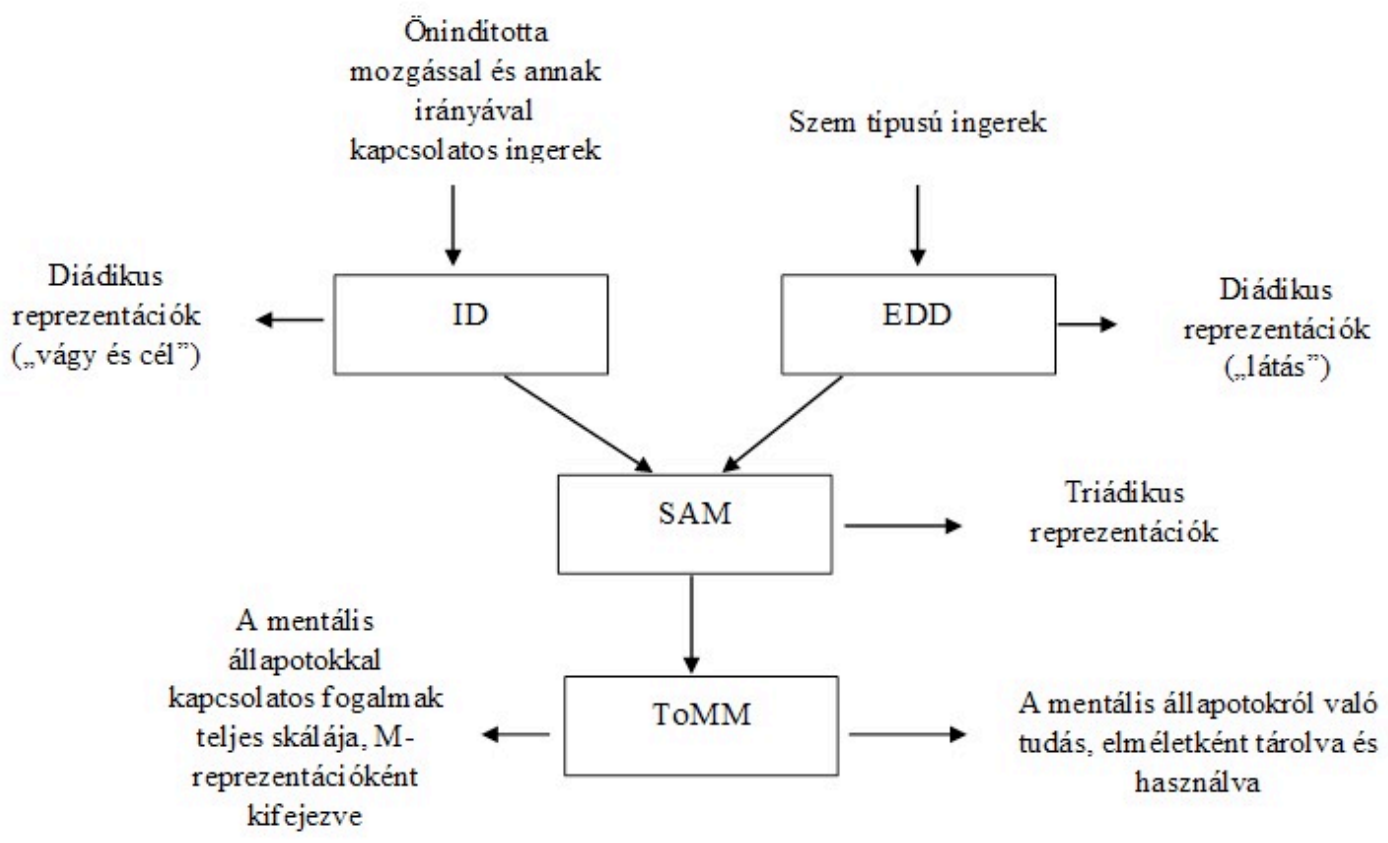

3. ábra: A tudatelmélet fejlődésének moduláris rendszere Baron-Cohen (1997. 32. o.) nyomán

Az áttekintett három legfontosabb elméleti megközelítés mellett még számos további elképzeléssel találkozhatunk a tudatelmélet értelmezése kapcsán. Az alapvető hasonlóság a három elméletben, hogy a tudatelmélet fejlödését folyamatosnak tekintik, vagyis a már explicit, tesztekkel mérhető tudatelmélet előfutárait is igyekeznek azonosítani. Különbségük elsősorban abban keresendő, hogy hogyan képzelik el a tudatelmélet kialakulását. Egyrészt a fejlődést tudományos folyamathoz hasonló elméletképzés és elméletváltások tükrében, vagy éppen a képzeleti képesség változásainak tükrében, esetleg a tudatelméleti modul kialakulása, differenciálódása tükrében képzelik el a fejlődést. Jelen disszertációban alkalmazott 
tudatelméletet mérő eljárások kialakítása Simon Baron-Cohen, a modularista elképzelés egyik képviselője kutatócsoportjának munkájához füződik. Ugyanakkor fontos azt tisztázni, hogy az általunk vizsgált életkori csoportok (5 éves kortól 75 éves korig) esetében már kialakultnak tekinthető a hamis vélekedés megértése. Azaz a klasszikus elméleti megközelítések fő kérdése, vagyis hogy mi okozza a 3 és 4 éves kori fejlődési változást, saját kutatásunkban már nem tekintjük relevánsnak. Sokkal inkább az a központi kérdésünk, hogy a tudatelmélet képessége valójában egy külön rendszerként képzelhető el, ami más funkcióktól függetlenül müködik (modularista megközelítés, Baron-Cohen, 1997), vagy éppen más kognitív funkciókkal együtt müködik-e a tudatelmélet, mely az időskori teljesítményromlás feltárásában és a fejlesztésben is fontos kérdés (1. Moran, 2013). Jelen disszertációban a tipikus fejlődés kapcsán egyrészt azt a kérdést vizsgáljuk, hogy vajon milyen életkori különbségek mutathatók ki a tudatelméleti képességben, illetve összefügg-e a tudatelmélet más kognitív funkciókkal, ezen belül pedig a munkamemória kapacitással. Az utóbbi kérdés amiatt is fontos, hogy az általunk alkalmazott méröeszközök mennyiben veszik igénybe a munkamemória

kapacitást. 


\section{A TUDATELMÉLET FEJLŐDÉSÉBEN SZEREPET JÁTSZÓ KÖRNYEZETI TÉNYEZŐK}

A tudatelmélet tipikus, normál ütemü fejlődését bizonyos tényezők kedvező irányban befolyásolják. Az egyéni változók közül például a nyelvi készségek, az általános kognitív funkciók kapcsolatban állnak a tudatelmélettel, azonban az egyéni változókon kívül fontos azoknak a környezeti tényezőknek is a vizsgálata, amelyek szerepet játszanak a tudatelméleti képesség fejlődésében. Ezek közül is a gyermekkori fejlődésre és a fejlődésben szerepet játszó családi tényezőkre fókuszálunk a továbbiakban.

A családi tényezők közül elsősorban a családszerkezet, a gyermek testvéreinek száma, illetve a családon belüli kommunikációs mintázatok tudatelméleti teljesítményre gyakorolt hatásait elemezték. Dunn és munkatársai (1991) vizsgálatának eredményei szerint azoknál a gyermekeknél, akik anyjukkal és testvéreikkel játéktevékenység közben olyan társalgást folytatnak, melyben mentális állapotok (szándékok, vágyak, érzelmek) szerepelnek, a tudatelmélet fejlődését ez nagymértékben elősegíti. Továbbá kimutatták, hogy a családban az érzésekről való beszélgetések gyakorisága és a testvérekkel való együttmüködés a 33 hónapos gyermekek esetében kapcsolatban áll a 7 hónappal (40 hónaposan mért) későbbi hamisvélekedés-teszten nyújtott teljesítménnyel és az érzelmek megértésével (Cutting és Dunn, 1999).

A szocio-ökonómiai státusz (SES) hatása még kevéssé vizsgált terület a tudatelmélet szempontjából. Cutting és Dunn (1999) vizsgálatában óvodás gyermekek hamisvélekedésteszten elért eredményeit, érzelemmegértését és családiháttér-változóikat hasonlították össze. A családiháttér-változók közül a családszerkezet, a gyermekkel együtt élő felnőttek száma, a beszélt nyelvek száma, az egy családban élő gyermekek száma, illetve a szülők iskolai végzettségét és foglalkozását elemezték. A kutatás eredményei alapján a családiháttérváltozók közül elsősorban a szülők foglalkozása és az anya iskolai végzettsége mutat kapcsolatot az óvodás gyermekek hamisvélekedés-teszten elért eredményeivel és az érzelmek megértésével. Pears és Moses (2003) elemezték a család demográfiai jellemzői és a tudatelmélet fejlettsége közötti kapcsolatot. Óvodáskorú gyermekek tudatelméleti fejlettségének legerősebb (ugyanakkor összességében mérsékelt összefüggést mutató) 
előrejelzője volt az anya iskolai végzettsége. A magyarázatok szerint az anyai iskolai végzettség direkt (a magasabb végzettségü anyák több időt töltenek a társas jelenségek magyarázatával) és indirekt (az általános kognitív képességeken keresztül) úton is hatással lehet a gyermek tudatelméleti képességére. A család anyagi helyzete pozitív kapcsolatban áll a gyermek teljesítményével, a család jövedelme feltehetően az anya magasabb iskolai végzettségén és a gyermekek kognitív képességein keresztül van hatással a tudatelméleti képességre. Ám a szülők családi állapotának nem volt jelentős magyarázóereje a tudatelméleti teljesítmény alakulására, vagyis nem magyarázta jelentős mértékben az, hogy a szülők családi állapota egyedülálló, avagy házasságban, párkapcsolatban élnek (Pears és Moses, 2003).

A család mérete is meghatározó tényező a tudatelmélet fejlődésében, egyéni különbségeiben. Perner, Ruffmann és Leakam (1994) kimutatták, hogy azok a gyermekek, akiknek testvérük van, jobban teljesítenek a hamisvélekedés-teszteken, mint az egyke gyerekek. Azok a 3-4 éves gyermekek, akiknek két vagy több testvérük volt, jobb teljesítményt nyújtottak a teszteken, mint akiknek egy testvérük volt, illetve az egyke gyerekeknek megközelítően a fele tudta teljesíteni a tesztet ebben a kutatásban (Perner, Ruffmann és Leakam, 1994). Jenkins és Astington (1996) ugyanezeket az eredményeket kapták, illetve azt is kimutatták, hogy a hamisvélekedés-teszten elért jobb teljesítményt nem befolyásolja, hogy a testvérek idősebbek vagy fiatalabbak, illetve a születési sorrendnek sincs szignifikáns hatása a teljesítményre. Eredményeik tehát azt támasztották alá, hogy minél nagyobb a család, minél több a testvérek száma, annál magasabb a gyermekek teszten elért teljesítménye.

Cutting és Dunn (1999) nem talált összefüggést a testvérek száma és a tudatelméleti fejlettség között, sokkal inkább a testvéri kapcsolat típusa és minősége van hatással a tudatelméleti teljesítményre, nem a testvérek száma (1. még Hughes és Ensor, 2005). Hasonlóan, Pears és Moses (2003) vizsgálatában nem volt kapcsolat a testvérek száma és a tudatelméleti teljesítmény között. McAllister és Peterson (2007) longitudinális vizsgálatukban arra az eredményre jutottak, hogy azok a gyermekek, akiknek két vagy több testvérük van, jobban teljesítenek a hamis vélekedés teszteken. Lewis, Freedman, Kyriakidou, MaridakiKassotaki és Berridge (1996) szerint az alábbiak vannak hatással a tudatelméleti teljesítményre: a felnőtt rokonok száma, akik a gyermek közvetlen környezetében élnek; a gyermek idősebb testvéreinek száma, illetve naponta a gyermekkel kapcsolatban álló idősebb gyermekek. McAllister és Peterson (2007) szerint a testvérek száma és a tudatelmélet 
fejlettsége közötti kapcsolat feltehetően abban keresendő, hogy a testvérek jelenléte a családban facilitálja a kortársak közötti kommunikációt és kapcsolatokat, és ezek vezethetnek a tudatelmélet gyors fejlődéséhez az óvodás korú (3-6 éves) gyermekek körében.

A szülői attitüd szintén befolyásolja a tudatelméleti képességet, óvodások esetében az anya és a gyermek közötti mentális állapotokról való beszélgetések gyakorisága, kidolgozottsága és tudatelméleti fejlettsége (hamisvélekedés-teszten elért eredménye) szignifikáns összefüggésben állnak (Peterson és Slaughter, 2003). Hasonlóan, a hároméves kori, anyával történő, mentális állapotokkal kapcsolatos beszélgetések egyértelmü és erős kapcsolatban állnak a később mért tudatelméleti teljesítménnyel (Ruffman, Slade, Devitt és Crowe, 2006; Ruffman, Slade és Crowe, 2002). A szülői nevelési módszerek közül a hatalmat gyakorló fegyelmezési stílus (a szülők kiabálással, fizikai büntetéssel vagy direkt utasítással fegyelmezik a gyermekeiket) nem segít a tudatelméleti fejlődés előmozdításában. A hatalmat gyakorló fegyelmezési stílus és a vélekedések megértése között negatív kapcsolat áll fenn még akkor is, ha a kognitív képességeket és a demográfiai hátteret kiszürték az elemzés során (Pears és Moses, 2003).

A családiháttér-változók közül a testvérek és más felnőtt családtagok szerepe, továbbá demográfiai változók is fontos szerepet töltenek be a tudatelméleti fejlődésben. A fejlődésnek fontos háttere tehát a család szerkezete, müködése. Ugyanakkor a tudatelmélet fejlődésében szerepet játszó kognitív funkciók, illetve a társas alkalmazkodás, szükebben az iskolai társas kapcsolatok hatékony kezelése szempontjából fontos a tudatelmélet és a társas viselkedés közötti kapcsolatnak, vagy éppen a kapcsolat hiányának a vizsgálata. Vagyis az, hogy hogyan funkcionál például a jobb kognitív funkciókkal rendelkező gyermek a tudatelméleti teszteken, vagy éppen a jobb tudatelméleti müködéssel jellemezhető gyermek a társas világban, a kortársak között. Természetesen fontos szempont az is, hogy vajon a kognitív funkciók, a családiháttér-változók, az iskolai sikeres társas alkalmazkodás milyen viszonyban állnak egymással, mennyiben müködhet például a tudatelmélet közvetítő változóként ebben a relációban. A következőkben a tudatelméletnek a kognitív funkciókkal és a társas viselkedéssel való kapcsolatának kutatási eredményeit ismertetjük. 


\section{A TUDATELMÉLET ÉS A KOGNITÍV FUNKCIÓK KAPCSOLATA}

A tudatelmélet kutatásában, fejlödési megközelítésében fontos kérdés, hogy vajon milyen kapcsolatban áll a mentális állapottulajdonítás képessége más kognitív funkciókkal. A tudatelmélet tipikus, normál ütemü fejlödését bizonyos tényezők kedvező irányban befolyásolják, például a 4 . fejezetben bemutatott családiháttér-változók. Ugyanakkor a környezeti tényezők mellett vannak olyan egyéni tulajdonságok, amik kapcsolatban állnak a tudatelméleti képességgel és annak fejlődésével. A kognitív funkciókkal való összefüggéseket több kutatásban is elemezték, közülük néhányat röviden kiemelek, a teljesség igénye nélkül. A nyelvi készségek fejlettségi szintje hatással van a tudatelméleti teljesítményre, vagyis azok a gyermekek, akiknek a nyelvi készségei korán kialakultak, elősegítik a tudatelmélet fejlődését, későbbi hamisvélekedés-teszten elért magasabb teljesítményt, azonban ez az összefüggés fordítva nem bizonyított (pl. Happé, 1995; Astington és Jenkins, 1999; Ruffmann, Slade és Crowe, 2002; Slade és Ruffmann, 2005). Mindemellett a tudatelmélet és a kognitív konstruktumok közötti kapcsolatra is rendelkezésünkre állnak adatok, például a tudatelméleti képesség és a kreativitás (pl. Suddendorf és Fletcher-Flinn, 1999), illetve az erkölcsi gondolkodás moral reasoning - pl. Dunn, Cutting és Demetriou, 2000) kapcsán. A továbbiakban a végrehajtó funkciókkal és a munkamemória kapacitással való kapcsolatra irányuló elméleti és empirikus megközelítéseket mutatom be, kutatásunk célja is elsősorban a munkamemória kapacitás és a tudatelmélet összefüggéseinek vizsgálata.

\subsection{Elméleti alapvetések a tudatelmélet és a kognitív funkciók kapcsolatáról}

A végrehajtó funkciók és a tudatelmélet kapcsolatának vizsgálata egyrészt abból ered, hogy agyi hátterük hasonló, hiszen mindkettő esetében a prefrontális kéreg központi területnek tekinthető (Ragsdale és Foley, 2011). Továbbá mind a tudatelmélet, mind a végrehajtó funkciók fejődésében a 3 és 4 éves korban gyors változások állnak be, csakúgy, mint a tudatelmélet fejlödésében, így kézenfekvő annak vizsgálata, hogy vajon milyen összefüggés lehet a két terület között, melyre számos elméleti megközelítés igyekezett magyarázatot találni (Doherty, 2009). A végrehajtó funkciók sokféle módon játszhatnak szerepet a hamisvélekedés-tesztekben, a Sally-Anne tesztváltozatban például az események 
sorrendjének nyomon követésében, csakúgy, mint Sally hamis vélekedésének vagy éppen a saját, a tárgy helyzetéről alkotott vélekedésének kikövetkeztetésében és fejben tartásában, e két vélekedés közötti interferencia kiküszöbölésében, illetve egy olyan válasz kialakításában, ami Sally vélekedésén, és nem az egyén saját vélekedésén alapszik (Apperly, 2011). A végrehajtó funkciók és a tudatelmélet közötti összefüggésekkel kapcsolatos elméleti megközelítéseket Doherty (2009) és Apperly (2011) áttekintése alapján ismertetem.

Az első megközelités az Apperly (2011) által leírt példát követi. Eszerint a tudatelméleti feladatokban számos végrehajtó müködést igénylő elem is megtalálható. A hamisvélekedés-tesztek megoldásában például a munkamemóriának nagyon fontos szerepe van, hiszen egy adott helyzetben egy másik perspektíva megértéséhez szükséges, hogy rövid távon meg tudjuk tartani az információkat az adott helyzetről. Továbbá a váltás képessége szintén elengedhetetlen ahhoz, hogy a gyermek a saját és a másik személy nézőpontja között képes legyen váltani. Mindezek mellett a gyermekeknek gátolniuk kell a saját reprezentációikat, amik sokszor sokkal hozzáférhetőbbek más személyek reprezentációihoz képest. Vagyis ez a három végrehajtó funkció (váltás, munkamemória és gátlás) a hamisvélekedés-tesztek megoldásában, csakúgy, mint más tudatelméleti tesztek megoldásában is szerepet játszhatnak. Ha a hamisvélekedés-tesztek végrehajtó funkcióbeli terhelését csökkentjük, akkor a gyermekek teljesítménye drámaian javul a tesztek megoldása során (Doherty, 2009). Hasonlóképpen fogalmazza meg ezt a megközelítést Apperly (2011) is, aki arra utal, hogy a végrehajtó funkciók szükségesek ahhoz, hogy kezelni tudjuk azt a terhelést, amit a tudatelméleti tesztek megkívánnak az egyes események sorrendjének fejben tartásához és a tesztekben megjelenő kérdések értelmezéséhez. Apperly (2011) összefoglalásában találkozhatunk azzal a megközelítéssel, amit „Expression”, vagyis „Kivitelezési” elgondolásnak nevez, miszerint a vélekedésekről való gondolkodáshoz számos specifikus képesség is hozzájárulhat. A hamis vélekedésekről való gondolkodáshoz elengedhetetlen, hogy a gyermek leküzdje azt az alapvető elgondolását, hogy a vélekedések igazak, illetve szükséges gátolnia azt a tendenciát, hogy a saját tudása vagy vélekedései alapján válaszoljon a hamisvélekedés-tesztekben, és képes legyen váltani a másik személy perspektívájára. Ez első látásra ugyan nagyon érdekes megközelítés, azonban nem magyarázza teljes körüen a gyerekek tudatelméleti feladatokon mért teljesítményét.

A második megközelités szerint a végrehajtó funkciók szükségesek a tudatelméleti képesség fejlődéséhez. Az egyik ezzel kapcsolatos megközelítés szerint a gyermekek 
rendelkeznek ugyan a mentális fogalmakkal, azonban hiányzik az a keret, amelyben megfelelően alkalmazni tudják ezeket a mentális fogalmakat. Például a tudatelmélet szimulációs elmélete szerinti szimuláció erőteljes végrehajtó funkció terheléssel jár, hiszen ideiglenesen felül kell írni a saját, leginkább hozzáférhető mentális állapotait, ez pedig erőteljes gátlókontroll funkciót, a mentális állapotok fejben tartása munkamemória kapacitást, illetve a váltás képességét is igényli (Doherty, 2009). A második elmélet szerint a végrehajtó funkciók szükségesek a mentális állapotokkal kapcsolatos fogalmak kialakításához, az végrehajtó funkciók a mentális állapotokkal kapcsolatos fogalmak alapkövei (Russel, 1996). Apperly (2011) összefoglalásában pedig „Emergence”, azaz „Kialakulási” megközelítésként szerepel az, hogy a végrehajtó funkciók fejlődése szükséges például a vélekedések absztrakt fogalmának megtanulásához.

A harmadik megközelités az előzővel éppen ellentétes irányt jelöl ki a végrehajtó funkciók és a tudatelmélet kapcsolatában, vagyis azt feltételezi, hogy a tudatelmélet szükséges feltétel a végrehajtó funkciók fejlődésében (Doherty, 2009). Perner (1991) szerint a végrehajtó funkciók kialakulásához például elengedhetetlen feltétel a metaraprezentációs képesség. Hiszen a hamisvélekedés-tesztek megoldásához szükséges, hogy a gyermek egyrészt reprezentálja kapcsolatot a vélekedés, illetve aközött a szituáció között, amit a vélekedés reprezentál, ez tulajdonképpen egy metareprezentációt megkívánó folyamat. Ezen felül azonban meg kell érteniük, hogy a vélekedések okozzák a cselekvéseket (Doherty, 2009). Apperly (2011) egy mindent felforgató, érdekes elméletként hivatkozik arra, ahogyan Perner és Lang (1999) érvelnek, miszerint a végrehajtó funkciók magukban foglalják az egyén saját mentális állapotainak top-down, vagyis felülről lefelé irányuló szabályozását, feltehetően a tudatelmélet fejlődése játszik szerepet a végrehajtó funkciók fejlődésében is.

A negyedik megközelités szerint a hamisvélekedés-tesztek éppen azért nehezek a gyermekek számára, mert különösen bonyolult logikai érvelés szükséges a megoldásukhoz (Doherty, 2009). Apperly (2011) „Competence”, azaz „Kompetencia” megközelítésként utal arra, hogy a hamis vélekedésekről való gondolkodáshoz szükséges az, hogy mentális reprezentációkat hozzunk létre, mindez pedig egy bizonyos szintủ komplexitást kíván meg. Vagyis amíg a gyermek nem rendelkezik elegendő kapacitással, addig nem tud a vélekedések vagy más mentális állapotok bonyolult müködéséröl gondolkodni és érvelni. Mindez arra utal, hogy a két terület kapcsolata abban keresendő, hogy hasonló szintü komplexitást kíván meg a tudatelméleti müködés és a végrehajtó funkciók müködése is (Müller és mtsai, 2012). 
A tudatelmélet és a végrehajtó funkciók között valamilyen fejlödésbeli, függő kapcsolat van. Az ezzel kapcsolatos empirikus eredményeket mutatom be a következőkben, melyek talán választ adhatnak arra, hogy melyik elméleti megközelítésbe illeszthető be a végrehajtó funkciók és a tudatelméleti müködés kapcsolata. Számos vizsgálat talált kapcsolatot a gyermekek hamisvélekedés-teszteken elért eredményei és a különböző módokon mért végrehajtó funkcióik között (Apperly, 2011).

\subsection{A végrehajtó funkciók, a munkamemória és a tudatelmélet közötti kapcsolat empirikus vizsgálatok alapján}

A tudatelmélet és a kognitív funkciók közötti összefüggéseket keresztmetszeti és longitudinális vizsgálatokban ellenőrizték, a továbbiakban a gyermekkorú, a serdülökorú és felnőtt-, illetve időskorú személyekkel végzett vizsgálati eredményeket ismertetem.

\subsubsection{A tudatelmélet, a munkamemória és a végrehajtó funkciók kapcsolata gyermekkorban}

Carlson és Moses (2001) óvodáskorú gyermekekkel végzett vizsgálatukban a gátlókontroll és a tudatelméleti képesség közötti összefüggéseket vizsgálták óvodáskorú gyermekek körében. A vizsgálat megközelítése szerint a végrehajtó funkciók mind a tudatelméleti múködés kivitelezésében, mind pedig a kialakulásában szerepet játszhat (1. az 5.1. fejezetben Apperly, 2011 összefoglalója nyomán). Mind a gátlókontroll, mind pedig a tudatelmélet fejlődése időbeli párhuzamot mutat (az óvodáskorban), hasonló agyi területhez köthetők, illetve mindkét képesség patológiás müködése az autizmusban jelentkezik. A kutatásban 3;3 év és 4;11 éves kor közötti gyermekek vizsgáltak egy összetett tesztbattériával. A kutatásban verbális képességeket mérő tesztet, egy tudatelméleti tesztbattériát (hamisvélekedés-tesztek, megtévesztésre irányuló teszt), két mentális állapotokkal kapcsolatos kontrollfeladatot, egy gátlókontrollt mérő tesztsorozatot (pl. Stroop jellegü feladatok), motoros szekvencia feladatot a motoros gyorsaság és a tervezési funkció mérésére, a mintha-játék fejlettségére egy mintha-cselekvés tesztet alkalmaztak, illetve szülöi beszámolókat elemeztek a gyermekek gátlókontroll funkcióiról. Az eredmények arra utalnak, hogy a gátlókontroll funkciók és a tudatelméleti feladatokon elért teljesítmény magas 
korrelációt mutatnak. Ez az erős összefüggés a beszéd fejlettségének, az életkornak, a nemnek, a család méretének, a mintha-játék fejlettségének és a mentális állapotokkal kapcsolatos kontroll feladatok eredményeinek kontrollálását követően is fennállt. Ugyanakkor a szerzők arra utalnak, hogy a végrehajtó funkciók és a tudatelméleti képesség közötti kapcsolat megismerésében a gátlókontroll mellett feltehetően a munkamemória kapacitása is szerepet játszik. Eredményeik tehát arra utalnak, hogy a gátlókontroll funkciók fejlődése facilitálhatja a tudatelmélet fejlödését, sőt feltehetően szükséges is hozzá, ugyanakkor nem elegendő feltétele a tudatelmélet müködésének (Carlson és Moses, 2001).

Carlson, Moses és Breton (2002) egy újabb vizsgálatukban tesztelték a tudatelmélet, a gátlókontroll és a munkamemória közötti összefüggéseket óvodáskorú gyermekek körében. Kutatásukban a WPPSI intelligenciateszt két verbális és performációs próbáját, egy tudatelméleti tesztbattériát, egy gátlókontrollt (konfliktus és késleltetés tesztek) és egy munkamemóriát mérő tesztsorozatot (számlálás és megnevezés, fordított szó- és számterjedelem teszt) alkalmaztak a vizsgált funkciók mérésére. Ebben a vizsgálatukban szintén azt találták, hogy a gátlókontroll és a tudatelméleti teljesítmény (hamisvélekedésteszttel mérve) szoros összefüggést mutat, még az intelligenciateszt verbális és performációs próbáin elért teljesítmények kontrollálását követően is. Ugyanakkor érdekes eredmény, hogy azok a feladatok, amik erőteljes gátlókontroll, de gyenge munkamemória terheléssel járnak, illetve fordítva, amelyek magas munkamemória, de alacsony gátlókontroll terheléssel járnak, nem mutatnak kapcsolatot a hamisvélekedés-megértéssel. Ezzel szemben azonban azok a feladatok, amelyek magas gátlókontroll és magas munkamemória terheléssel járnak, már összefüggésben állnak a hamisvélekedés-teszteken mutatott teljesítménnyel. Ezek az eredmények tehát arra utalnak, hogy a gátlókontroll és a munkamemória kapacitás együttesen játszanak meghatározó szerepet a tudatelméleti teljesítményben óvodáskorú gyermekeknél (Carlson, Moses és Breton, 2002).

Longitudinális vizsgálati elrendezésben Carlson, Mandell és Williams (2004) óvodáskorú gyermekek végrehajtó funkcióinak és tudatelméleti képessége kapcsolatának változásait vizsgálták két és három éves korukban. Kétéves korban a végrehajtó funkciókat mérő öt feladattal a domináns válaszok kontrollálásának képességét mérték, míg a tudatelméletet mérő eljárásokkal a szándékok megértését, a vágyak különbözőségének megértését, a vizuális perspektívát és a mintha-játékot vizsgáló eljárásokat alkalmaztak, illetve a szülőktől beszámolót kértek a gyermekük temperamentumáról, verbális fejlettségéről. 
A második vizsgálati alkalommal, a gyermekek hároméves korában pedig a gyermekek verbális képességét, a végrehajtó funkcióit és a tudatelméleti képességét (hamisvélekedéstesztekkel is kiegészítve) mérték fel a szülői beszámolók mellett. Eredményeik szerint a kétéves korban mért végrehajtó funkciók és a tudatelmélet viselkedéses mérése között nem találtak kapcsolatot, azonban hároméves korban már erős összefüggések mutathatók ki a két terület között. Ugyanakkor a kétéves korban mért végrehajtó funkciók előrejelzik a hároméves korban mért tudatelméleti teljesítményt, még a verbális képességek és az anya iskolai végzettségének kontrollálását követően is (Carlson, Mandell és Williams, 2004).

Hughes és Ensor (2007) longitudinális vizsgálatukban szintén arra az eredményre jutottak, hogy a kétéves korban mért végrehajtó funkciók előrejelezték a három- és négyéves korban mért tudatelméleti teljesítményt, a verbális képességek, a nem, a szociális státusz, az életkor és a kétéves korban mért tudatelméleti teljesítmény kontrollálását követően is. A hároméves korban mért végrehajtó funkciók és a négyéves korban mért tudatelméleti teljesítmény közötti korreláció is szignifikáns volt ugyan, azonban az említett kontrollált változók kiszürését követően már nem volt kimutatható ez a kapcsolat. Továbbá a kétéves korban mért tudatelméleti teljesítmény és a négyéves korban mért végrehajtó funkciók között összefüggést találtak a kutatásban (Hughes és Ensor, 2007).

Egy sokkal frissebb longitudinális vizsgálatban Müller és munkatársai (2012) ugyancsak óvodáskorú gyermekek körében vizsgálták a végrehajtó funkciók és a tudatelmélet összefüggéseit, kétéves, hároméves és négyéves korban, évenként beiktatott mérési pontokkal. A kutatásban végrehajtó funkciók és a tudatelméletet mérő tesztbattériák mellett verbális képességeket is mértek a gyermekek 3 és 4 éves korában. Az eredményeik szerint a végrehajtó funkciók előrejelzik a tudatelméleti teljesítményt a verbális képességek, az életkor, a nem és a kezdeti tudatelméleti képességek kontrollálását követően is. Ugyanakkor arra az eredményre jutottak, hogy a 2 és 3 éves korban mért versengő ingerek gátlásának képessége jobb előrejelzője a későbbi tudatelmélet müködésnek, mint a téri munkamemória kapacitása. Illetve szintén arra az eredményre jutottak, hogy a tudatelméleti müködés nem előrejelzője a későbbi végrehajtó funkcióknak. Továbbá a kétéves korban mért tudatelméleti teljesítmény és a négyéves korban mért végrehajtó funkciók között a hároméves korban mért verbális képességek közvetítő változóként jelentek meg az elemzésekben. Vagyis a tudatelmélet és a későbbi végrehajtó funkciók közötti kapcsolat nem direkt, hanem a verbális képességeken 
keresztül van hatással a végrehajtó funkciókra (Müller, Liebermann-Finestone, Carpendale, Hammond és Bibok, 2012).

Razza és Blair (2009) longitudinális kutatásukban szintén óvodáskorúakat vizsgált, azonban a vizsgálati mintába alacsony keresetű családokban nevelkedő gyermekek kerültek. Érdekessége a kutatásnak, hogy nemcsak a végrehajtó funkciókat és a hamisvélekedésmegértés kepésségét hasonlította össze hosszmetszeti stratégiában, hanem a szociális kompetencia mérésével is kiegészítették vizsgálatukat. Az első mérési ponton a gyermekek átlagéletkora 5 év volt, majd egy év múlva végeztek ismételt méréseket. A tesztbattériában hamisvélekedés-teszteket alkalmaztak a tudatelmélet mérésére, míg a végrehajtó funkciókat mérő teszteken a gátlókontrollt és munkamemória fejlettségét mérték, illetve a verbális képességek felmérésére is sor került. A szociális kompetencia mérését kérdőíves módszerrel végezték, a pedagógusok értékelték a gyermekek szociális kompetenciáját (az ezzel kapcsolatos eredményeket a későbbiekben, a társas viselkedéssel kapcsolatos fejezetben ismertetem). Az első mérés során mért végrehajtó funkciók, ezek közül is elsősorban a gátlókontroll és a később mért hamisvélekedés-megértés között találtak kapcsolatot (Razza és Blair, 2009).

Az említett, óvodáskorú gyerekekkel végzett vizsgálatok elsősorban arra utalnak, hogy a tudatelméleti müködés és a végrehajtó funkciók, ezen belül elsősorban a gátlókontroll funkciója között tapasztalható erős korreláció (Carlson és Moses, 2001). Hasonló kapcsolatot longitudinális kutatásokban (Carlson, Mandell és Williams, 2004; Hughes és Ensor, 2007; Müller és mtsai, 2012) is megerősítették, ugyanakkor azzal a fontos, fejlődésre utaló adattal kiegészítve, hogy a korábbi életkorban mért végrehajtó funkciók előrejelzik a későbbi tudatelméleti teljesítményt, azonban fordított összefüggés nem áll fenn az eddigi adatok alapján, tehát nem állíthatjuk, hogy a tudatelmélet elörejelzi a későbbi végrehajtó funkciókat. Fontos azonban, hogy ezek a vizsgálatok más vizsgálati eszközöket alkalmaztak az egyes funkciók mérésére, továbbá pusztán az óvodáskorú gyermekek tudatelméleti és kognitív funkciók közötti kapcsolatról ad számot. Érdekes kérdés azonban, hogy a későbbi életkorokban, serdülőkorban és felnőtt-, továbbá időskorban ezek a végrehajtó funkciók és tudatelméleti müködés között mutatható-e ki kapcsolat, illetve ha igen, ez a kapcsolat milyen irányú. 


\subsubsection{A tudatelmélet, a munkamemória és a végrehajtó funkciók kapcsolata serdülö-, felnőtt- és időskorban}

A tudatelmélet tipikus fejlődését tárgyaló 3. fejezetben ismertettem, hogy a , illetve az időskori tudatelmélet alakulásában a kognitív funkciók is szerepet játszhatnak. Vetter és munkatársai (2013) az affektív tudatelmélet és gátlás, frissítés és váltás képességének összefüggéseit vizsgálták serdülőkorban és fiatal felnőtteknél. Az affektív tudatelméleti teljesítménnyel összefüggött a végrehajtó funkciók működése, ezek közül elsősorban a gátlás mutatott magas összefüggéseket az affektív tudatelmélettel. Fiatal felnőttek esetében a végrehajtó funkciók és a tudatelméleti képesség között változatos összefüggések tapasztalhatók. German és Hehman (2006) idős és fiatal felnőttek vizsgálatában arra a következtetésre jutott, hogy a tudatelmélet a munkamemóriával (számterjedelem és fordított számterjedelem tesztekkel mérve), a feldolgozási sebességgel és a gátlókontrollal mutat összefüggéseket, azonban a tudatelméleti teljesítményt leginkább a gátlókontroll és a feldolgozási sebesség magyarázták.

Lin, Keysar és Epley (2010) vizsgálatukban arra az elvre alapozott, miszerint feltételezhető, hogy az alacsonyabb munkamemória kapacitással rendelkező személyek számára nehezebb a mentális állapottulajdonítás folyamata, a tudatelméleti teszteken alacsonyabb színvonalú teljesítményt mutatnak. Vizsgálatukban felnőtt személyeket alacsony, illetve magas munkamemória kapacitású csoportokra osztottak (egy számolási művelet pontosságának eldöntése, majd az alatta lévő szó felolvasása), és a referenciális kommunikációs feladat megoldására kérték őket, melyben a vizsgálati személynek a kísérletben szintén részt vevő másik személy vélekedésének kikövetkeztetésével kell az utasításait követni. Az alacsonyabb munkamemória kapacitással rendelkező személyek egyrészt lassabbak, másrészt pedig több hibát vétenek a tudatelméleti feladatban a magasabb munkamemória kapacitással rendelkezőkhöz képest (Lin, Keysar és Epley, 2010). Hasonlóan Phillips és munkatársai (2011) pedig idősebb korosztályban mutatták ki a munkamemória szerepét. Kutatásukban arra az eredményre jutottak, hogy az idősebb felnőttek kevésbé jól teljesítenek a hamisvélekedés-teszteken a fiatal felnőttekhez képest, azonban ezt a különbséget elsősorban a munkamemória teljesítmény eltérései magyarázzák a két csoport között. 
A fentebb felsorolt vizsgálatok a tudatelméleti müködés és a végrehajtó funkciók, illetve a munkamemória kapcsolatát korrelációs vizsgálatokkal igyekeztek bizonyítani, akár keresztmetszeti, akár longitudinális kutatási stratégiával. Ezen túlmenően azonban a kettős terheléssel (dual-task helyzetben) végzett kutatások tudnak igazán számot adni arról, hogy valójában, a tudatelméleti müködés folyamatában milyen szerepet játszhatnak a kognitív funkciók (Apperly, 2013). McKinnon és Moscovitch (2007) kimutatták, hogy fiatal felnőtteknél kettős terheléses helyzetben az egyidejü munkamemória teljesítmény aránytalanul rontja a tudatelméleti teljesítményt. Ez a teljesítményromlás kifejezettebb a másodrendủ hamisvélekedés-tulajdonításra vonatkozó kérdések esetén, hiszen a magasabb rendű mentálisállapot-tulajdonítás folyamata során több perspektívát kell egyidejüleg figyelembe vennie a vizsgálati személynek, így ez nagyobb munkamemória terheléssel jár. Azaz az általános kognitív funkciók, ezen belül a munkamemória müködése szerepet játszik az elmeolvasás folyamatában. Linn, Epley és Keysar (2010) vizsgálatában felnőttek esetében mutatta ki, hogy az emlékezeti terhelés mellett megoldott tudatelméleti (referenciális kommunikációs feladat) teszt során kevésbé képesek a vizsgálati személyek alkalmazni a másik személy perspektíváját akkor, ha a másik személy utasításait kell követni. Hasonlóan, Qureshi, Apperly és Samson (2010) egyidejü tudatelméleti és gátlókontroll feladatmegoldás során arra az eredményre jutott, hogy a felnőtt vizsgálati személyek hajlamosak inkább saját, egocentrikus nézőpontjukból megítélni egy másik személy perspektíváját. Vagyis ezek a kutatási eredmények arra utalnak, hogy a tudatelméleti feladatok mellett egyidejüleg alkalmazott memóriaterheléssel járó, vagy gátlókontrollt igénybe vevő feladatok jelentősen ronthatják a tudatelméleti teljesítményt.

Ugyanakkor fontos azt is figyelembe venni ezeknél a vizsgálatoknál, hogy akár a korrelációs, akár a kettős terheléses stratégiát alkalmazó kutatások eredményeit nagyban befolyásolhatják a módszertanból fakadó sajátosságok is. Hiszen a legtöbb kutatásban különféle tudatelméleti teszteket alkalmaznak, így felmerül a kérdés, hogy vajon egyes tudatelméleti vizsgálati módszerek ugyanolyan mértékben terhelik-e meg a munkamemória kapacitásunkat, vagy éppen a végrehajtó funkcióinkat.

Ahogyan Ahmed és Miller (2011) vizsgálata rámutat, különböző tudatelméleti tesztekkel mért mentális állapottulajdonításban a végrehajtó funkciók különbözői területei játszanak szerepet. Míg az affektív tudatelmélet mérésére alkalmazott Szemekből Olvasás Teszt eredményeivel egyik végrehajtó funkció sem mutatott összefüggéseket, addig a Strange 
Stories (Furcsa történetek) teszt eredményeit a verbális fluencia és a deduktív érvelés, a Faux Pas teszten elért eredményeket pedig a verbális fluencia és a problémamegoldás teljesítménye jelezte elöre. Egyik tudatelméleti mérőeljárás sem mutatott kapcsolatot egymással a vizsgálatban, emiatt feltételezhető, hogy eltérő domaineket mérnek, és eltérő kognitív funkciókat igényelnek a vizsgálati személyek részéről (Ahmed és Miller, 2011). Az eredmények arra utalnak, hogy a tudatelméletet mérő eljárásoktól függően játszanak szerepet a kognitív funkciók a mentális állapottulajdonítás folyamatában.

Az áttekintett elméleti kérdések és a kutatási eredmények tehát arra utalnak, hogy a tudatelmélet és a kognitív funkciók (a végrehajtó funkciók, a munkamemória) kapcsolatban állnak egymással. Ezek az összefüggések korrelációs, longitudinális és kettős terheléses helyzetben is megjelennek. Fontos kérdés azonban annak vizsgálata, hogy a tudatelmélet és az általános kognitív funkciók kapcsolata vajon a különböző életkorú csoportokat összehasonlítva hogyan alakul. Az eddig általunk áttekintett vizsgálati eredmények általában óvodáskorú gyermekeket, vagy serdülőket és fiatal felnőtteket, illetve fiatal felnőtteket időskorú személyekkel hasonlították össze, azonban hiánypótló lehet annak vizsgálata, hogy az egyes életkor csoportok között különbözik-e a tudatelmélet fejlettsége, illetve a tudatelméleti müködés és a munkamemória, vagy éppen a végrehajtó funkciók kapcsolata. Saját vizsgálatunkban a tudatelmélet kognitív funkciókkal való kapcsolatának feltárására törekszünk. Ugyanakkor további tényező a tudatelméletnek a társas viselkedésben megmutatkozó hatása, hiszen a tudatelmélet definíciója szerint társas-kognitív képesség, mely a társas alkalmazkodásunkban elengedhetetlen képesség (Kiss, 2005), így fontosnak tartom áttekinteni, vajon milyen szerepet tölt be a társas viselkedésben a tudatelmélet képessége. 


\section{A TUDATELMÉLETI KÉPESSÉG ÉS A TÁRSAS VISELKEDÉS KAPCSOLATA}

A tudatelmélet társas-kognitív képességnek tekinthető, a szociális alkalmazkodásunk egy kulcsképessége, fejlődésében is szerepet játszanak a szociális ingerek, interakciók. Fontos tehát az, hogy a tudatelméleti müködés milyen kapcsolatban áll a valós szociális készségekkel. Elengedhetetlen annak vizsgálata, hogy a laboratóriumban végzett tudatelméleti tesztek és a szociális készségek között kimutatható kapcsolat vajon a való életben is megjelenik-e (Baron-Cohen, 2001). Számos tanulmány született a tudatelméletnek a szociális viselkedéssel és szociális kompetenciával való összefüggésének vizsgálatára.

A kutatások eredményei arra utalnak, hogy a tudatelmélet a szociálisan kompetens viselkedéssel (pl. Lalonde és Chandler, 1995), vagy a társas kapcsolatok minőségével együtt jár (Slaughter és Repacholi, 2003). A kutatások eredményei arra utalnak, hogy a magasabb szintü tudatelméleti müködéssel rendelkező gyerekek sikeresebbek a társas kapcsolatokban, mint az alacsonyabb szintü tudatelméleti képességgel rendelkező gyerekek. Azonban a magasabb szintű tudatelmélet nem garantálja egyértelműen a társas sikerességet, hiszen vannak olyan gyermekek és felnőttek, akik jó tudatelméleti képességüket antiszociális célokra használják (Slaughter és Repacholi, 2003). Vagyis a tudatelméleti képesség és a társas viselkedésbeli következmények vizsgálata nagyon összetett terület, melyben sok ellentmondás fedezhető fel.

A tudatelméleti kutatások kezdetben arra világítottak rá, hogy a mentalizációs képesség társas alkalmazkodásban betöltött szerepe elsősorban a tudatelméleti zavarok kapcsán érthető meg. Baron-Cohen, Leslie és Frith (1985) autizmussal élő gyerekek vizsgálata kapcsán feltételezte a tudatelmélet deficitjét, mely a szociális interakciókban történő zavarra adhat magyarázatot autizmusban. Ezt a kezdeti kutatást számos további vizsgálat követte mind autizmusban (pl. Baron-Cohen, O’Riordan, Stone, Jones és Plaisted, 1999; Baron-Cohen, Weelwright, Hill, Raste és Plumb, 2001), mind pedig más fejlődési zavarokban, illetve pszichiátriai zavarokban is.

Az iskolai alkalmazkodás kapcsán számunkra inkább a tipikusan fejlődő gyermekek szociális alkalmazkodásával kapcsolatos eredmények a fontosak. Számos ellentmondással találkozhatunk a kutatások során, hiszen a valós társas környezetben való alkalmazkodás, a 
társas interakciók kezelése, és a laboratóriumban, mesterséges körülmények között felvett tudatelméleti tesztek között sok esetben nincs összhang. Ha egy gyermek például nem tud teljesíteni egy tudatelméleti tesztet, az még nem feltétlenül jelenti azt, hogy a társas helyzetekben ne tudna alkalmazkodni, vagy a másik személy perspektíváját átvenni, vágyait, érzelmeit megérteni. Vagyis annak ellenére például, hogy egy 3 éves korú gyermek még nem teljesíti a hamisvélekedés-tesztet, sikeresen képes kezelni a társas helyzeteket (Astington, 2003).

A következőkben ismertetett vizsgálati eredmények mindkét szempontra rávilágítanak, vagyis a tudatelmélet és a szociális kompetencia közötti pozitív összefüggésekre, illetve az összefüggések hiányára. A tipikusan fejlődő populációban elsősorban óvodáskorú és iskoláskorú gyermekekkel végzett kutatásokban igyekeztek vizsgálni a tudatelmélet és a társas viselkedés közötti kapcsolatokat. A kutatások rendkívül heterogének, nem csak a gyermekek életkora, vagy az alkalmazott tudatelméleti mérőeljárások változatossága miatt, hanem abban a tekintetben is, hogy a társas viselkedést milyen módszerekkel mérik fel. A társas viselkedés vizsgálatára az áttekintett kutatásokban alkalmaznak szociometriai módszert, a pedagógusok vagy a szülök kikérdezését a gyermek társas viselkedéséröl, a gyermekek saját beszámolói, illetve a proszocialitás megítélése is szerepelnek a változatos kutatási módszerek között. A következő fejezetekben (6.1. és 6.2.) bemutatom a tudatelmélet és a társas viselkedés óvodás- és iskoláskorra jellemző szerteágazó kapcsolatát néhány empirikus kutatás adatai alapján.

\subsection{A tudatelmélet és a társas viselkedés összefüggései óvodáskorú gyermekeknél}

Az óvodáskorú gyermekekkel végzett vizsgálatok nagy többségében hamisvélekedésteszteken mérik a tudatelméleti teljesítményt, a szociális viselkedés mérését pedig elsősorban a szülők és a pedagógusok kikérdezése alapján végezték a kutatásokban. Newton, Reddy és Bull (2000) vizsgálatában a tudatelméleti teljesítmény és a mindennapi életben megfigyelt, a gyermekek édesanyjuk által regisztrált megtévesztések között nem találtak szignifikáns összefüggéseket 3-4 éves korú gyermekek körében. Ennek ellentmondó eredmény ugyanakkor, hogy hároméves gyermekek hamisvélekedés-teszten nyújtott teljesítménye, és a 
pedagógus által megítélt társas viselkedése között összefüggést találtak (Lalonde és Chandler, 1995). Hasonlóan Watson és munkatársai (1999) 3 és 6 éves gyermekek hamisvélekedésteszten elért eredményei és a pedagógus által megítélt szociális készségei között találtak összefüggéseket. A hamisvélekedés-teszten nyújtott teljesítmény szignifikáns előrejelzője volt a pedagógus által megítélt társas viselkedésüknek. Nagyobb mintán, hasonló életkorú gyerekekkel végzett vizsgálataik szintén megerősítették a hamisvélekedés-teszten nyújtott teljesítmény és a társas viselkedés közötti összefüggéseket (Watson, Nixon, Wilson és Capage, 1999).

Walker (2005) vizsgálatában 3-5 éves korú gyermekek hamisvélekedés-teszten nyújtott teljesítménye és a pedagógusok által megítélt társas viselkedése közötti összefüggéseket tárt fel. A pedagógusok által megítélt viselkedést három területen vizsgálta: a negatív vagy pozitív viselkedés játékhelyzetben (kooperatív játék, verbális vagy fizikai agresszió), más gyermekek játékához csatlakozás stratégiái, illetve konfliktusokban való részvétel, illetve azok megoldási stratégiái. A tanári értékelések alapján három faktorba sorolhatók a társas viselkedési minták: a proszocialitás, az agresszivitás vagy bomlasztó viselkedés, illetve a szerénység vagy visszahúzódó viselkedés területei tartoztak (Walker, 2005). Az eredmények arra utalnak, hogy a tudatelmélet összefüggésben áll az agresszív, vagy bomlasztó viselkedéssel a fiúk esetében, míg a lányok esetében a proszociális viselkedéssel jelez pozitív kapcsolatot, ugyanakkor negatív összefüggésben áll a visszahúzódó viselkedéssel a fiúk körében (Walker, 2005).

Slaughter, Dennis és Pritchard (2002) vizsgálatukban öt különböző tudatelméleti teszten nyújtott teljesítményt vetette össze a gyerekek szociometriai státuszával 4-6 éves gyerekek körében. Az eredményeik szerint az 5 évesnél idősebb gyerekek körében szignifikáns összefüggést mutatnak az összesített tudatelméleti teljesítményük és a társak általi kedveltségük között, a népszerü gyerekek magasabb szinten teljesítenek a tudatelméleti teszteken, mint az elutasított társaik. Másik vizsgálatukban szintén 4-6 éves gyerekeket vizsgáltak, a szociometriai pozíció, a tudatelméleti müködés, a verbális intelligencia, illetve a pedagógus által megítélt proszociális vagy agresszív viselkedés összefüggéseiben. Ebben a vizsgálatban az 5 évesnél idősebb gyermekek körében az összesített tudatelméleti teljesítmény volt a legerősebb előrejelzője a társak általi elfogadásnak. Az eredmények arra utalnak, hogy a tudatelméletnek van ugyan szerény hatása a társak általi elfogadottságra, ez az összefüggés pedig az életkor előrehaladtával nő (Slaughter, Dennis és Pritchard, 2002). 
Razza és Blair (2009) longitudinális kutatásukban a szociális kompetenciát, a végrehajtó funkciók müködését és a hamisvélekedés-teszttel mért tudatelméleti teljesítményt vetették össze, ahogyan azt a 5.2.1. fejezetben, a végrehajtó funkciókat tárgyaló fejezetben ismertettük. A szociális kompetencia, a végrehajtó funkciók és a hamisvélekedés-megértés kepesség összehasonlítását végezték alacsony keresetű mintában. Az első mérési ponton a gyermekek átlagéletkora öt év volt, majd egy év múlva végeztek ismételt méréseket. A szociális kompetencia mérésére egy viselkedési skálát alkalmaztak, ennek is a szociális készségek skálájának értékelésére kérték meg a pedagógusokat, mely alapján a gyermekek tipikus, osztályteremben mutatott viselkedését osztályozták. Ezáltal a gyermekek társas helyzetekben mutatott együttműködését, a társas interakciókat és a társas önállóságot térképezték fel. Az eredmények szerint a korábbi hamisvélekedés-megértés összefüggésben áll a későbbi szociális kompetenciával (Razza és Blair, 2009).

James, Astington és Pelletier (2000) longitudinális vizsgálatukban a tudatelméleti képességet a metakognitív nyelvi képességekkel és az iskolai teljesítménnyel összefüggésben vizsgálták, kontrollálva az általános nyelvi képességeket és a családi hátteret. A kutatás legfontosabb kérdése az volt, vajon a mentális állapotok tulajdonításának képessége mennyire kapcsolódik össze az iskolai sikerekkel, ez utóbbiba beletartoznak a gyermek akadémiai és társas készségei is. A longitudinális kutatásban két éven keresztül követték a gyerekeket, az iskolába lépésüktől kezdve (a vizsgálat kezdetén a gyerekek átlagéletkora a fiatalabb életkori csoportban 4,4 év, míg az idősebb életkori csoportban 5,4 év volt). A tudatelmélet mérésére a kutatás első évének elején hamsivélekedés-teszteket vettek fel a gyerekekkel, illetve a második év végén pedig másodrendü hamisvélekedés-teszteket alkalmaztak. A gyermekek szociális kompetenciáját, szociális viselkedését a tanárok által kitöltött kérdőívvel mérték, mindkét évben más mérőeszközt alkalmazva. A vizsgálat sajátossága volt, hogy az első év közepén, illetve a második év elején is felvették a kérdőívet a pedagógusokkal, gyerekek ekkorra új közösségbe kerültek, más pedagógusok tanították öket. Az eredményeik szerint a gyermekek hamisvélekedés-teszten mért teljesítménye előre jelzi a kutatás második évének végén mért szociális kompetenciát. Vizsgálták a gyerekek saját tapasztalatait önbeszámolójuk alapján az iskoláról, a pedagógus-diák kapcsolatról és a kortárskapcsolatokról is. Eredményeik szerint a gyerekek pozitív iskolai tapasztalatai és a másodfokú hamisvélekedésteszten elért teljesítményük között pozitív, míg a gyerekek negatív tapasztalatai és az első- és másodfokú hamisvélekedés-teszten elért eredményei között negatív kapcsolatot találtak. 
Továbbá kapcsolatot találtak a pedagógus által értékelt szociális kompetencia és a gyerekek saját tapasztalatai között, pozitív kapcsolat volt kimutatható a pozitív tapasztalatokkal rendelkező gyerekeket a pedagógusaik is magasabb szociális kompetenciával rendelkezőnek jellemezték, a negatív tapasztalatokkal rendelkező gyerekeket pedig kevésbé kompetensnek ítélték meg a pedagógusaik. Az eredmények arra utalnak, hogy a hamis vélekedés megértése ugyan szükséges bizonyos szociális viselkedések megértéséhez, azonban nem elégséges a szociális müködéshez (Astington, 2003).

\subsection{A tudatelmélet és a társas viselkedés összefüggései iskoláskorúaknál}

Az iskoláskorú gyermekekkel végzett vizsgálatokban már az életkori sajátosságok miatt a magasabb rendü tudatelméletet mérő teszteket alkalmaznak. Ennek egyik legfontosabb előnye, hogy valósághübb szituációk alkalmazásával méri a gyermekek mentális állapottulajdonítását, ezek a szituációk pedig közelebb állnak a valós társas helyzetekhez, így a kutatások érvényessége is megnőhet.

Liddle és Nettle (2006) kutatásukban magasabb szintü tudatelmélet és a szociális készségek vizsgálatát tüzték ki célul 10-11 éves gyermekek körében. Magasabb rendü tudatelméleti feladatokat alkalmaztak, illetve a tanárok számára készített kérdőívvel vizsgálták a gyerekek szociális kompetenciáját. A tudatelméleti feladatokban a klasszikus elsőrendü, a másodrendü, illetve harmad- és negyedrendű mentális állapottulajdonítás is szerepelt. Eredményeik szerint a gyerekek az első- és másodrendű tudatelméleti feladatokat teljesítették a legtöbben, illetve a szociális kompetenciával pozitív összefüggéseket mutattak ki a tudatelméleti teljesítménnyel (Liddle és Nettle, 2006).

A kutatásokat ért kritikák elsősorban arra vonatkoznak, hogy a hamisvélekedés-tesztek nem elég naturalisztikusak, vagyis nem ragadják meg azt a komplexitást, amit egy valós társas helyzet állít a gyermekek elé. Ennek kapcsán Banerjee és Watling (2005) egy longitudinális projekt keretében a gyerekek tudatelméleti müködését a Faux Pas teszttel vizsgálták, ami egy komplex, valós szituációkat exponáló történetsorozat, sokkal közelebb áll a valós társas szituációkhoz. A tudatelméleti teszten elért teljesítményt a szociometriai pozícióval összefüggésben vizsgálták. Eredményeik szerint az elutasított és az ellentmondásos/ambivalens státuszú gyerekek, akik több negatív jelölést kaptak a táraiktól, 
tudatelméleti teszten elért teljesítményük alacsonyabb szintủ a faux pas teszttel mérve. Ez az összefüggés, az idősebb, 8-9 éves gyerekek almintájában volt kifejezett, a fiatalabb, 5-6 éves korosztályban ezt a hatást nem figyelték meg. Egy későbbi tanulmányukban (Banerjee, Watling és Caputi, 2011) ugyanezen gyerekek 2 éves, követéses vizsgálatát mutatták be, ugyancsak a Faux Pas teszttel mért tudatelméleti teljesítményt hasonlították össze a gyerekek szociometriai pozíciójával. Az eredmények arra utalnak, hogy a 7 éves kori, csoporton belüli elutasítás bejósolja az alacsonyabb szintü faux pas megértést 8 éves korban, hasonló hatást figyeltek meg a 9 éves kori elutasítottság és a 10 éves kori faux pas megértés színvonala között. Viszont a 9 éves kori, magasabb szintü faux pas megértés együttjár a 10 éves kori társak általi elfogadottsággal, illetve a 10 éves korban mért alacsonyabb faux pas megértés bejósolja a 11 éves kori elutasítottságot. A szerzők szerint a későbbi kutatások rávilágíthatnak a faux pas teljesítmény és a társak általi elutasítottság közötti mediáló változókra (Banerjee, Watling és Caputi, 2011). Egy további, szintén longitudinális vizsgálatban az általános iskolába történő átmenet során követték a gyermekeket 5 éves koruktól egészen 7 éves korukig, három mérési ponton, évenkénti vizsgálatokkal. A gyermekek tudatelméleti képességét, a proszociális viselkedését, illetve a verbális képességeiket mérték fel, továbbá a hat- és hétéves korban a társak általi elfogadást és elutasítást is elemezték. A szerzők szerint a tudatelmélet és a későbbi, alacsony szintű elutasítottság és a társak általi elfogadottság közötti összefüggések indirektek, feltehetően a proszociális viselkedés fejlődése lehet a közvetítő változó ebben a relációban (Caputi, Lecce, Pagnin és Banerjee, 2012).

A tudatelmélet és a társas viselkedés kapcsolatában végzett kutatások metaanalízise során megállapították, hogy gyenge, de pozitív irányú kapcsolat van a gyermekek magasabb szintü tudatelméleti müködése és a társak közötti népszerüség között, ez az összefüggés azonban nem változik az életkorok összehasonlításában, ugyanakkor a lányok esetében erősebb. Érdekesség ugyanakkor, hogy a tudatelméletnek a társak közötti népszerüséggel szorosabb, míg az elutatítottsággal gyengébb a kapcsolata (Slaughter, Imuta, Peterson és Henry, 2015).

Az áttekintett kutatások eredményei szerint a tudatelmélet és a társas viselkedés, a társakkal való kapcsolat között feltételezhetünk összefüggéseket, azonban a mérések alapján ez az együttjárás elég gyengének, vagy éppen közepes erősségünek mutatkozik. Ennek hátterében egyrészt a már említett módszertani heterogenitás, a mesterséges szituációkat 
modellező tudatelméleti tesztek problémája, illetve az az ellentmondás állhat, miszerint a jó tudatelméleti képességet akár antiszociális célokra is használhatják iskoláskorban.

\subsection{A tudatelmélet és a társas viselkedés ellentmondása: a bullying}

A szociális kompetencia és a tudatelmélet összefüggéseire irányuló kutatások ellentmondásainak magyarázatában felmerült a bullying tényezője is, hiszen elképzelhető, hogy a jó tudatelmélet képességekkel rendelkezők akár antiszociális célokra is használják a jó színvonalú mentális állapottulajdonítási képességeiket (1. Slaughter, 2003). A bullying kifejezést magyar nyelven iskolai zaklatásnak, iskolai agressziónak szokták fordítani, ugyanakkor a továbbiakban a bullying kifejezést használjuk. A bullying egy olyan ismétlődő viselkedés, ami folyamatosan megjelenik az egyenlőtlen erőfölénnyel és hatalommal jellemezhető kapcsolatokban, és ezekben a helyzetekben nehéz megvédenie magát a bántalmazott gyermeknek (Olweus, 1994; Margitics, Figula, Pauwlik és Szatmári, 2010)

A kutatások egyik központi kérdése, hogy a bullyingban részt vevő zaklatókra tudatelméleti alulmüködés vagy éppen tudatelméleti előny jellemző, hiszen ezek a gyerekek általában magatartási problémákkal, nehezebb társas alkalmazkodással küzdenek. Azonban nincsenek egyértelmü eredmények, hiszen a nehezen kezelhetö, vagy éppen magatartászavarral küzdő gyermekek rosszabbul teljesítenek a hamis vélekedés teszteken, illetve amennyiben teljesítik azt, nincs összhangban a való életben tapasztalható szociális müködéssel. Ennek ellentmond viszont az a tényező, hogy a zaklató általában dominánsabb, manipulatív gyermek, ehhez viszont magasabb szintü tudatelméleti müködésre van szüksége (Sutton, 2003). Egy longitudinális ikerkutatás keretében kapott eredmények szerint az 5 éves korban mért, alacsonyabb tudatelméleti teljesítmény összefüggésben áll a serdülőkori bullyingban való részvétellel. Azok a serdülők, akik akár áldozatok, akár provokatív áldozatok, akár zaklatók, alacsonyabb színvonalú gyermekkori tudatelméleti teljesítménnyel jellemezhetők, a háttérváltozók hatásának is komoly szerepe lehet azonban a jelenség vizsgálatában (Sania és mtsai, 2012). Az iskolai zaklatás jelenségének, az elkövetők, a provokatív áldozatok, illetve az áldozatok zaklatásban való szerepének jobb megértéséhez is szükséges a tudatelmélet minél részletesebb feltérképezése, továbbá a szociális kompetencia egyes komponenseivel való kapcsolatának vizsgálata. 
$\mathrm{Az}$ áttekintett eredmények sok ellentmondást tartalmaznak, és gyenge együttjárást találtak a szociális kompetencia egyes aspektusai és a tudatelméleti teljesítmény között. Fontos azonban hangsúlyozni, hogy a vizsgálatokban alkalmazott tudatelméleti tesztekben általában egy jól körülhatárolt, explicit problémával találkozik a gyermek, a szociális világ problémái és konfliktusai viszont nem mindig pontosan definiáltak, illetve több személlyel interakcióban folynak. A klasszikus vizsgálóeljárások mellett szükséges olyan kutatásokat végezni, amelyekben realisztikusabb tudatelméleti teszteket alkalmaznak (1. Banerjee, Watling és Caputi, 2011). 


\section{AZ EMPIRIKUS VIZSGÁLAT CÉLJAI, HIPOTÉZISEI}

$\mathrm{Az}$ áttekintett elméleti alapok és kutatási eredmények alapján több kutatási kérdést is megfogalmaztunk, melyeket három külön vizsgálatban ellenőrzünk. A vizsgálatsorozat célja a tudatelmélet életkori különbségeinek és egyes faktorainak vizsgálata.

Az első vizsgálatunk célja a tudatelméleti képesség életkori különbségeinek feltárása, a kognitív és az affektív komponensek tükrében, középpontban a Faux Pas Felismerése Tesztet (Stone, Baron-Cohen és Knight, 1998; Baron-Cohen és mtsai, 1999) alkalmazva, ami a tudatelmélet kognitív és affektív komponensét is méri (Harari és mtsai, 2010). A tudatelmélet óvodáskor utáni feltárása, a tudatelméleti képesség kognitív és affektív komponensei életkori különbségeinek vizsgálata széles életkori spektrumon, magyar mintán még hiánypótló.

A második vizsgálatunk célja a tudatelméleti képességgel kapcsolatban álló faktorok feltárása. Egyrészt fontos tényezőnek tartjuk, hogy a kognitív funkciók milyen kapcsolatban állnak a tudatelméleti teljesítménnyel, illetve a tudatelméleti képesség kognitív és affektív komponenseivel. A keresztmetszeti (pl. Carlson és Moses, 2001), illetve a longitudinális kutatások (pl. Carlson, Mandell és Williams, 2004; Müller és mtsai, 2012) szerint gyermekkorban a gátlókontroll és a tudatelméleti képesség között összefüggés van. Felnőtt- és időskorban a tudatelméleti képesség áll kapcsolatban a munkamemória kapacitással (pl. German és Hehman, 2006; Lin, Keysar és Epley, 2010; Philips és mtsai, 2011). A vizsgálatokban heterogén mintában, változatos eszközökkel tárták fel ezeket az eredményeket, célunk, hogy minden korcsoportban azonos teszteljárásokkal tárjuk fel a tudatelméleti képesség és a munkamemória kapacitásának összefüggéseit.

A harmadik vizsgálatunk fó célja a tudatelméleti képesség és a társas viselkedés, ezen belül pedig a szociometriai pozíció közötti kapcsolatok feltárása. Az iskolás korosztályban a társas hatékonyság és a tudatelmélet közötti kapcsolatok vizsgálata még hiánypótló, vagyis célunk annak vizsgálata, hogy a tudatelmélet a társas viselkedés egyes mutatóival hogyan függ össze. A korábbi kutatások során (Banerjee és Watling, 2005; Banerjee, Watling és Caputi, 2011) kapott mérsékelt összefüggések tükrében mutathatunk-e ki összefüggést a tudatelméleti képesség és a társas pozíció között. 


\subsection{Az első vizsgálat kutatási céljai és hipotézisei}

Az első vizsgálatunkban arra a kérdésre kerestük a választ, hogy az egyes életkori csoportok között felfedezhetők-e különbségek a tudatelméleti képességben. Az áttekintett kutatási eredmények tükrében várható, hogy a tudatelméleti képesség a serdülökor végéig, fiatal felnőttkorig változik, továbbá időskorban hanyatlást mutat (Dumontheil és mtsai, 2010; Duval és mtsai, 2010; Sebastian és mtsai, 2012; Altgassen és mtsai, 2014). A témában eddig született vizsgálati eredmények két vagy három korosztályi csoport összehasonlításában jeleztek eltéréseket különböző életkori csoportok között (Happé és mtsai, 1998; Maylor és mtsai, 2002; Duval és mtsai, 2010). Hiánypótló annak vizsgálata, hogy vajon egyes életkori csoportokban 5 éves kortól 75 éves korig milyen különbségeket mutat a tudatelméleti képesség, mind az affektív, mind pedig a komplex tudatelméleti teljesítmény mérésével. Vizsgálatunkban két nagyobb korcsoport, a gyermekek (5-11 éves korig) és a serdülők és felnőttek (11-75 éves korig) életkori csoportjában végeztünk vizsgálatokat. Az első vizsgálat két nagyobb korcsoportra bontását elsősorban módszertani okok indokolják, hiszen a gyermekkorú vizsgálati személyek esetében a tudatelmélet mérése során a Faux Pas Felismerése Teszt gyermek változatával dolgoztunk, amely elsősorban 7 és 11 éves korban alkalmas a komplex tudatelmélet mérésére (Baron-Cohen és mtsai, 1999). Míg a Faux Pas Felismerése Teszt felnőtt változatával inkább felnőttkorban végeztek vizsgálatokat (pl. Stone, Baron-Cohen és Knight, 1998; Harari és mtsai, 2010; Gál, Katona, Janacsek és Németh, 2014), illetve serdülök körében is ismertek kutatási eredmények (Gál, Egyed, Pászthy és Németh, 2011) így saját vizsgálatunkban a felnőtt változat esetében egy módszertani kérdésre is keressük a választ, miszerint mely életkortól alkalmazható megfelelően a teszt felnőtt változata.

Mindezek alapján az első vizsgálat hipotézisei:

Az 5-11 éves korú vizsgálati személyek esetében feltételezzük, hogy

1. a komplex tudatelméleti képesség a Faux Pas Felismerése Teszttel mérve a gyermekkorú tesztváltozattal mért életkori csoportokban (5-11 év) különbségeket mutat, a magasabb életkori csoportokba tartozók tudatelméleti teszten elért teljesítménye magasabb színvonalú. 
2. a Faux Pas Felismerése Teszt egyes összetevőinek (elszólás detektálása, téves vélekedés megértése) értékelése során gyermekkorú tesztváltozattal mért életkori csoportokban (5-11 év) különbségeket mutat, a magasabb életkori csoportokba tartozók tudatelméleti teszten elért teljesítménye magasabb színvonalú.

3. az affektív tudatelméleti müködés a Faces Teszttel mérve a gyermekkorú életkori csoportokban (5-11 év) különbségeket mutat, a magasabb életkori csoportokba tartozók tudatelméleti teszten elért teljesítménye magasabb színvonalú, ez az életkori különbség a Faces Tesztben megjelenő komplex érzelmek felismerése esetében is megjelenik, ugyanakkor az alapérzelmek felismerése tekintetében nem találunk életkori különbségeket.

4. a kognitív tudatelméleti müködés a másodrendü hamisvélekedés-teszttel mérve a gyermekkorú (5-11 év) életkori csoportokban különbségeket mutat, a magasabb életkori csoportokba tartozók tudatelméleti teljesítménye magasabb színvonalú.

5. a nem szerinti különbségekkel kapcsolatban feltételezzük, hogy a lányok jobb színvonalon teljesítenek a tudatelméletet mérő tesztek mindegyikén a fiúkhoz képest.

6. a gyermekkorban felvett kognitív tudatelméleti müködést vizsgáló másodfokú hamisvélekedés-tesztet sikeresen teljesítő gyermekek magasabb teljesítményt nyújtanak a komplex tudatelméletet mérő Faux Pas Felismére Teszten, mint a másodfokú hamisvélekedés-tesztet nem teljesítő gyermekek, hiszen a tudatelmélet fejlődésében a másodfokú mentálisállapot-tulajdonításra 5-6 évesen, míg a faux pas-k megértésére 9-11 éves korban képesek (Brüne és Brüne-Cohrs, 2006; Westby és Robinson, 2014).

A 11-75 éves korú személyek kel végzett vizsgálatokban feltételezzük, hogy

1. a komplex tudatelméleti képesség a Faux Pas Felismerése Teszttel mérve különbséget mutat az egyes életkori csoportokban (11-75 év), a fiatal felnőtt vizsgálati csoportba tartozó személyek jobb színvonalon teljesítenek a serdülőkhöz képest, illetve az idős korcsoportokba tartozók tudatelméleti teljesítménye alacsonyabb színvonalú. 
2. a Faux Pas Felismerése Teszt egyes összetevőinek (hamis vélekedés megértése, affektív mentálisállapot-tulajdonítás megértése) értékelése során különbséget mutat az egyes életkori csoportokban (11-75 év), a fiatal felnőtt vizsgálati csoportba tartozó személyek jobb színvonalon teljesítenek a serdülőkhöz képest, illetve az idős korcsoportokba tartozók tudatelméleti teljesítménye alacsonyabb színvonalú.

3. az affektív tudatelméleti müködés a Faces Teszttel mérve különbséget mutat az egyes életkori csoportokban (11-75 év), a fiatal felnőtt vizsgálati csoportba tartozó személyek jobb színvonalon teljesítenek a serdülőkhöz képest, illetve az idős korcsoportokba tartozók tudatelméleti teljesítménye alacsonyabb színvonalú, ez az életkori különbség a Faces Tesztben megjelenő komplex érzelmek felismerése esetében is megjelenik, ugyanakkor az alapérzelmek felismerése tekintetében nem találunk életkori különbségeket.

4. a nem szerinti eltérések kapcsán feltételezzük, hogy a nők jobb színvonalon teljesítenek a tudatelméletet mérő tesztek mindegyikén a férfiakhoz képest.

\subsection{A második vizsgálat kutatási céljai és hipotézisei}

Második vizsgálatunkban arra kerestük a választ, hogy a tudatelmélet és a kognitív funkciók, ezen belül a munkamemória kapacitás milyen kapcsolatban állhatnak egymással. A kutatási eredmények arra utalnak, hogy a végrehajtó funkciók, a munkamemória összefüggésben áll a tudatelméleti képességgel óvodáskorban (Carlson és Moses, 2001), illetve felnőtt- és időskorban egyaránt (pl. McKinnon és Moscovitch, 2007; Lin, Keysar és Epley, 2010; Philips és mtsai, 2011). Ugyanakkor fontos kérdés annak vizsgálata, hogy vajon a tudatelmélet mennyire tekinthető egy különálló modulnak, vagy más kognitív funkcióktól nem teljesen független képességnek tekinthető (Baron-Cohen, 1997; Moran, 2013). Kutatásunk célja volt, hogy gyermekkorban, több életkori csoportból álló mintán, illetve felnőttkorban egészen időskorig hogyan alakul a kognitív funkciók, elsősorban a munkamemória kapacitás és a tudatelmélet kapcsolata. Vizsgálatunkban két nagyobb korcsoport, a gyermekek (7-11 éves korig) és a serdülők és felnőttek (11-75 éves korig) életkori csoportjában végeztünk vizsgálatokat. A második vizsgálatba bevont személyek két nagyobb korcsoportra bontását elsősorban módszertani okok indokolják, hiszen a gyermekkorú vizsgálati személyek esetében 
a tudatelmélet mérése során a Faux Pas Felismerése Teszt gyermek változatával dolgoztunk, amely elsősorban 7 és 11 éves korban alkalmas a komplex tudatelméleti működés mérésére (Baron-Cohen és mtsai, 1999). A Faux Pas Felismerése Teszt felnőtt változatával elsősorban felnőttkorban végeztek vizsgálatokat (pl. Stone, Baron-Cohen és Knight, 1998; Harari és mtsai, 2010; Gál, Katona, Janacsek és Németh, 2014), illetve serdülök körében is ismertek kutatási eredmények (Gál, Egyed, Pászthy és Németh, 2011).

Mindezek alapján a második vizsgálat hipotézisei:

A 7-11 éves korú vizsgálati személyek esetében feltételezzük, hogy

1. a Számterjedelem Teszttel mért verbális munkamemória kapacitása, illetve a Fordított Számterjedelem Teszttel és a Hallási Mondatterjedelem Teszttel mért munkamemória kapacitás és a Faux Pas Felismerése Teszttel mért komplex tudatelméleti teljesítmény között pozitív kapcsolat feltételezhető.

2. a Számterjedelem Teszttel mért verbális munkamemória kapacitása, illetve a Fordított Számterjedelem Teszttel és a Hallási Mondatterjedelem Teszttel munkamemória kapacitás és a Faux Pas Felismerése Teszt egyes összetevői (elszólás detektálása, téves vélekedés megértése és emlékezeti kérdések) között pozitív kapcsolat feltételezhető.

3. a Számterjedelem Teszttel mért verbális munkamemória kapacitása, illetve a Fordított Számterjedelem Teszttel és a Hallási Mondatterjedelem Teszttel munkamemória kapacitás és a Faces Teszttel mért affektív tudatelméleti teljesítmény között pozitív kapcsolat feltételezhető.

4. a Számterjedelem Teszttel mért verbális munkamemória kapacitása, illetve a Fordított Számterjedelem Teszttel és a Hallási Mondatterjedelem Teszttel munkamemória kapacitás és Másodfokú Hamisvélekedés-teszttel mért kognitív tudatelméleti teljesítmény között pozitív kapcsolat feltételezhető a 7-11 éves korosztályban. 
A 11-75 éves korú vizsgálati személyekkel végzett vizsgálatban feltételezzük, hogy

1. a Számterjedelem Teszttel mért verbális munkamemória kapacitása, illetve a Fordított Számterjedelem Teszttel és a Hallási Mondatterjedelem Teszttel mért munkamemória kapacitás és a Faux Pas Felismerése Teszttel mért komplex tudatelméleti teljesítmény között pozitív kapcsolat feltételezhető.

2. a Számterjedelem Teszttel mért verbális munkamemória kapacitása, illetve a Fordított Számterjedelem Teszttel és a Hallási Mondatterjedelem Teszttel mért munkamemória kapacitás és a Faux Pas Felismerése Teszt egyes összetevő (téves vélekedés megértése és emlékezeti kérdések) között pozitív kapcsolat feltételezhető.

3. a Számterjedelem Teszttel mért verbális munkamemória kapacitása, illetve a Fordított Számterjedelem Teszttel és a Hallási Mondatterjedelem Teszttel mért munkamemória kapacitás és a Faces Teszttel mért affektív tudatelméleti teljesítmény között pozitív kapcsolat feltételezhető. 


\subsection{A harmadik vizsgálat kutatási céljai és hipotézisei}

A harmadik vizsgálatunk célja elsősorban a társas viselkedés és a tudatelméleti képesség közötti összefüggések feltárása volt. Mivel az áttekintett kutatási eredmények nem egyértelmü kapcsolatot jeleznek a két terület között (pl. Newton, Reddy és Bull, 2000; Sutton, 2003; Walker, 2005) így különösen fontos annak vizsgálata, hogy a tudatelméleti képesség és a társas viselkedés között milyen irányú összefüggések tárhatók fel. Hiánypótló egy szélesebb életkori spektrumon, keresztmetszeti vizsgálatban, azonos módszerekkel felmérni a két konstruktum kapcsolatát. A korábbi kutatások számos eltérő módszerrel vizsgálták a tudatelméleti müködést (pl. hamisvélekedés-tesztekkel, faux pas teszttel, pl. Liddle és Nettle, 2006; Razza és Blair, 2009; Banerjee, Watling és Caputi, 2011) és a társas viselkedést is (pl. szociometriai pozíció, társak általi elfogadottság, tanári és szülői értékelések, pl. Newton, Reddy és Bull, 2000; James, Astington és Pelletier, 2000; Astington, 2003; Banerjee és Watling, 2005). Az ellentmondásos eredmények hátterében véleményünk szerint nem pusztán a tudatelméleti tesztek „mesterséges” volta, hanem a módszertani sokszínüség is állhat, vagyis nehezen tudunk összehasonlítani olyan kutatási eredményeket, amelyek eltérő módszerekkel vizsgálják a tudatelméleti képességet és a társas viselkedést.

Ugyanakkor Banerjee és Watling (2005), illetve Banerjee, Watling és Caputi (2011) vizsgálataikban azonos módszerekkel mérték fel a tudatelméleti képességet, míg a társas viselkedés mérését a szociometria módszerével végezték, viszont más-más kiértékelési módszert választottak a szociometriai pozíció megítélésére. Kutatásunk célja az volt, hogy iskoláskorú gyermekek körében két tudatelméleti mérőeljárás segítségével feltérképezzük a tudatelméleti képesség és a szociometriai pozíció kapcsolatát, kiegészítve a méréseket a munkamemória kapacitás mérésével, hiszen fontos annak is vizsgálata, hogy a tudatelmélet mellett a munkamemória milyen kapcsolatban állhat a szociometriai pozícióval. A szociometriai mérést a Banerjee és Watling (2005), illetve Banerjee, Watling és Caputi (2011) vizsgálataikban két külön értékelési módszerrel végezték, mindkét értékelési formát mi is alkalmazzuk saját vizsgálat mintánkon, az értékelési rendszert a kutatási módszerek leírásánál (9.3.1. fejezet) részletesen ismertetjük. A társas pozícióval kapcsolatos vizsgálatainkat 8-14 éves korú gyermekek körében végeztük. 
Mindezek alapján a harmadik vizsgálatunkban feltételezzük, hogy

1. a komplex tudatelmélet és a szociometriai pozíció kapcsolatban áll egymással, azaz a népszerünek értékelt gyermekeknek magasabb szintű a tudatelméleti teljesítményük, míg az elutasított gyermekek tudatelméleti teljesítménye alacsonyabb színvonalú a Faux Pas Felismerése Teszttel mérve.

2. az affektív tudatelmélet és a szociometriai pozíció kapcsolatban áll egymással, azaz a népszerünek értékelt gyermekeknek magasabb szintü a tudatelméleti teljesítményük, míg az elutasított gyermekek tudatelméleti teljesítménye alacsonyabb színvonalú a Faces Teszttel mérve.

3. a komplex tudatelmélet és társak általi elfogadottság/elutasítottság között kapcsolat feltételezhető, a magasabb elfogadottság magasabb szintű tudatelméleti teljesítménnyel jár együtt, míg a magasabb elutasítottság alacsonyabb szintü tudatelméleti teljesítménnyel jár együtt, a Faux Pas Felismerése Teszttel mérve.

4. az affektív tudatelméleti és társak általi elfogadottság/elutasítottság között kapcsolat feltételezhető, a magasabb elfogadottság magasabb szintü tudatelméleti teljesítménnyel jár együtt, míg a magasabb elutasítottság alacsonyabb szintü tudatelméleti teljesítménnyel jár, a Faces Teszttel mérve. 


\section{AZ EMPIRIKUS VIZSGÁLATOKBAN RÉSZT VEVÖ MINTA JELLEMZÖI}

A következőkben a vizsgálatsorozatunkban részt vevő minták és alminták jellemzőit, leíró adataikat ismertetjük. Mindhárom vizsgálatban a mintavétel hozzáférés alapú volt. Az adatok elsősorban egy Csongrád megyei város és környékéről származtak, illetve Magyarország más településeiről is vontunk be vizsgálati személyeket, azonban mintánk nem reprezentatív. A vizsgálatsorozatban a személyek önkéntes alapon vállalták a vizsgálatokat. A gyermekkorú vizsgálati személyek a szülő aktív, informált beleegyezésével, míg a felnőttkorú vizsgálati személyek aktív, informált beleegyezésüket követően vettek részt a vizsgálatsorozatban. A személyek, illetve a szülök számára tájékoztatást adtunk a vizsgálat menetéröl, biztosíttuk őket az anonimitásról, az adatok bizalmas kezeléséről, melynek érdekében a személyek vizsgálata kódszámmal történt. A Magyar Pszichológiai Társaság és a Szegedi Tudományegyetem Bölcsészettudományi Kar Pszichológiai Intézetének etikai kódexét betartottuk a vizsgálatok során.

\subsection{Első vizsgálat: a tudatelmélet életkori különbségeinek vizsgálata}

A vizsgálatban összesen 299 fő vett részt, a mintát két almintára bontottuk. A Faux Pas Felismerése Teszt gyermek tesztváltozatával mért alminta 172 főből állt (átlagéletkor: 8,93 év, szórás: 1,79 év; 82 fiú, 90 lány), míg a Faux Pas Felismerése Teszt felnőtt tesztváltozatával mért alminta pedig 127 főből állt (átlagéletkor: 28,50 év, szórás: 18,9 év; 61 férfi, 66 nő, iskolázottság átlaga években: 10,35). A minta két korosztályra bontását módszertani okok indokolták, a Faux Pas Felismerése Teszt gyermek változata 7-11 éves korban méri megfelelően a tudatelmélet müködést (Baron-Cohen és mtsai, 1999), míg a serdülő és felnőttkorú mintában a Faux Pas Felismerése Teszt felnőtt változatát alkalmaztuk.

Főbb elképzelésünk a tudatelméleti teszteken megjelenő életkori különbségek vizsgálata, és az egyes tudatelméleti tesztek (Faces Teszt és a Faux Pas Felismerése Teszt) összevetése. A csoportok megfelelő elemszáma és az előzetes szakirodalmi adatok alapján a 
személyeket életkori övezetekbe soroltuk, összesen 11 életkori csoportot határoztunk meg a két almintában.

A Faux Pas Felismerése Teszt gyermek tesztváltozatát alkalmazó almintában a következő csoportosítást végeztük el: 1) 5-6 éves korig, 2) 7-8 éves korig, 3) 9 éves kor, 4) 10 éves kor, 5) 11 éves kor. A csoportosítást elsősorban az indokolta, hogy a teszt eredeti változatával végzett vizsgálatokban 7-9-11 éves korú gyermekek csoportjai vettek részt, hiszen a faux pas felismerésének képessége 9-11 éves korban alakul ki, ennek okán fontos feltérképezni ebben a szükebb életkor spektrumban a teszttel mérhető életkori különbségeket (Baron-Cohen és mtsai, 1999).

A Faux Pas Felismerése Teszt felnőtt tesztváltozatát alkalmazó almintában pedig hat életkori csoportot határoztunk meg, melyek az alábbiak voltak: 1) 11 éves kor, 2) 12 éves kor, 3) 13-17 éves korig, 4) 18-29 éves korig, 5) 30-59 éves korig, 6) 60-75 éves korig. A felnőttek és az idősek esetében 20 éves bontást alkalmaztunk az életkori csoportok meghatározásakor. Ugyanakkor mivel a felnőtt Faux Pas Felismerése Teszt alkalmazásának életkori alsó határa tudomásunk szerint nincs kialakítva, ezáltal mivel a faux pas felismerésének képessége 9-11 éves korban jelenik meg, már 11 éves gyermekek esetében is fontosnak tartottuk alkalmazni a teszt felnőtt változatát. Mindezt amiatt tartottuk indokoltnak, mivel a faux pas felismerés képessége 9-11 éves korban alakul ki, így fontos módszertani kérdésként fogalmazódott meg, hogy a 11 éves korú személyeknél a Faux Pas Felismerése Teszt felnőtt változata milyen mértékben alkalmazható. Továbbá így lehetőségünk lehetett összehasonlítani a gyermekkori, a serdülőkori és felnőtt, valamint az időskori tudatelméleti teljesítményt is ezzel a mérőeszközzel, ugyanakkor ennél fiatalabb mintán történő alkalmazása feltehetően inkább padlóhatást eredményezett volna. A gyermek és a felnőtt mintában az életkori csoportok leíró adatait a 6. táblázatban közöljük. 
6. táblázat. Az életkor átlaga és szórása az egyes életkori övezetekben

\begin{tabular}{|c|c|c|}
\hline Alminták & Életkori csoport (n) & $\begin{array}{c}\text { Életkori átlag } \\
\text { (szórás) }\end{array}$ \\
\hline \multirow{5}{*}{$\begin{array}{l}\text { Gyermek } \\
\text { tesztváltozattal } \\
\text { vizsgált minta }\end{array}$} & 5-6 év $(n=21)$ & $5,29(0,46)$ \\
\hline & $7-8$ év $(n=32)$ & $7,61(0,61)$ \\
\hline & 9 év $(n=47)$ & $9(0)$ \\
\hline & 10 év $(n=36)$ & $10(0)$ \\
\hline & 11 év $(n=36)$ & $11,03(0,1)$ \\
\hline \multirow{6}{*}{$\begin{array}{l}\text { Felnőtt } \\
\text { tesztváltozattal } \\
\text { vizsgált minta }\end{array}$} & 11 év $(n=18)$ & $11(0)$ \\
\hline & 12 év $(n=20)$ & $12(0)$ \\
\hline & 13-17 év $(n=22)$ & $15,45(1,19)$ \\
\hline & 18-29 év $(n=23)$ & $26,74(2,38)$ \\
\hline & 30-59 év $(n=23)$ & $38,8(9,09)$ \\
\hline & $60-75$ év $(n=21)$ & $63,48(2,9)$ \\
\hline
\end{tabular}




\subsection{Második vizsgálat: a tudatelmélet és a munkamemória kapacitás kapcsolatának vizsgálata}

A vizsgálatban összesen 240 fö vett részt, két almintát alakítottunk ki. A Faux Pas Felismerése Teszt gyermek tesztváltozatával mért alminta létszáma 113 fő (átlagéletkor: 9,41 év, szórás: 1,38 év; 53 fiú, 60 lány), míg a Faux Pas Felismerése Teszt felnőtt tesztváltozatával mért alminta létszáma 127 fö (átlagéletkor: 29,16 év, szórás: 18,34; 59 férfi, 68 nő, iskolázottság átlaga: 10,93 év). A minta két korosztályra bontását módszertani okok indokolták, a Faux Pas Felismerése Teszt gyermek változata 7-11 éves korban méri megfelelően a tudatelmélet müködést (Baron-Cohen és mtsai, 1999), míg a serdülő és felnőttkorú mintában a felnőtt változatot alkalmaztuk.

Főbb elképzelésünk a tudatelméleti teszteken (Faces Teszt és a Faux Pas Felismerése Teszt) és a munkamemória teszteken (Számterjedelem, Fordított Számterjedelem, Hallási Mondatterjedelem) elért teljesítmények kapcsolatának vizsgálata, azaz a tudatelméleti működés és a munkamemória kapacitás kapcsolatának feltérképezése

\subsection{Harmadik vizsgálat: a tudatelmélet és a társas viselkedés kapcsolatának vizsgálata}

A vizsgálatba összesen 137 főt vontunk be, két almintát alakítottunk ki. A Faux Pas Felismerése Teszt gyermek tesztváltozatával mért alminta létszáma 100 fó (átlagéletkor: 8,83 év, szórás: 0,84 év; 47 fiú, 53 lány), míg Faux Pas Felismerése Teszt felnőtt tesztváltozatával mért serdülőkorú alminta létszáma 37 fö (átlagéletkor: 13 év, szórás: 1,31; 12 fiú, 25 lány). A minta két korosztályra bontását módszertani okok indokolták, a Faux Pas Felismerése Teszt gyermek változata 7-11 éves korban méri megfelelően a tudatelmélet müködést (BaronCohen és mtsai, 1999), míg a serdülőkorú mintában a felnőtt változatot alkalmaztuk.

Főbb elképzelésünk szerint a tudatelméleti teszteken (Faces Teszt és a Faux Pas Felismerése Teszt) elért teljesítmény és a szociometriai pozíció között kapcsolat feltételezhető, vagyis a magasabb társak általi elfogadottság, illetve a népszerüség magasabb tudatelméleti müködéssel áll kapcsolatban. 


\section{AZ EMPIRIKUS VIZSGÁLAT MÓDSZEREI}

\subsection{A tudatelmélet mérésére alkalmazott eljárások}

A tudatelmélet mérésére leggyakrabban alkalmazott eljárások közül saját vizsgálatainkban a komplex tudatelméletet mérö Faux Pas Felismerése Teszt gyermek (Baron-Cohen, Stone, Jones és Plaisted, 1999), illetve felnőtt tesztváltozatát (Stone, Baron-Cohen és Knight, 1998) alkalmaztuk a vizsgálati személyek életkorához igazodva. Az affektív tudatelmélet mérését a Faces Teszttel (Baron-Cohen, Weelwright és Jollife, 1997; magyar változat Ivády Rozália, é.n.) végeztük, továbbá a 5-11 éves életkori csoportban a másodfokú hamisvélekedés-teszttel (Stefanik, 2005) is vizsgáltuk a tudatelméleti képességet, a Faux Pas Felismerése Teszttel összehasonlításban. A tudatelméletet mérő eljárásokat az Autism Research Centre (Autizmus Kutató Központ, University of Cambridge) weboldalán hozzáférhető tesztekböl választottuk, melyért az Autizmus Kutató Központot köszönet illeti (www.autismresearchcentre.com).

\subsubsection{A kognitív tudatelmélet mérésére alkalmazott eljárás kisiskolás korban}

\subsubsection{Másodfokú hamisvélekedés-teszt}

A másodfokú hamis vélekedés-tulajdonítási feladatok közül jelen vizsgálatban a Baron-Cohen (1989) által kidolgozott verziót alkalmaztuk, magyar nyelven Stefanik (2005) autizmussal élő személyekkel végzett vizsgálatában használta a mérỏeszközt. A tesztben egy történet szerepel két gyermekről, amelyet a vizsgálati személy számára felolvasunk. A történet egy városban játszódik, négy szereplöje a fagylaltárus, Jancsi, Mari és Jancsi anyukája. A történetet a mellékletben ismertetjük. A történet felolvasása során 6 megértést segítő kontrollkérdést teszünk fel, majd a történet befejeztével egy tesztkérdést alkalmaztunk a másodfokú hamisvélekedés-megértés ellenőrzése céljából („Mit gondol Mari, hová ment Jancsi fagyit venni?”). A tesztkérdést követően egy indoklásra vonatkozó kérdés („Miért gondolja ezt Mari?”), egy realitásra vonatkozó kontrollkérdés („Hová ment igazából Jancsi fagyit venni?”), illetve egy emlékezeti kontrollkérdés („Hol volt a fagylaltárus a történet legelején?") szerepelt (Stefanik, 2005). A tesztkérdésre vonatkozó választ helyesnek vagy helytelennek minősítettük, illetve amennyiben az emlékezeti kontrollkérdésre helytelenül válaszolt a vizsgálati személy, úgy az ő válaszait kiszürtük az elemzésből. A tipikus fejlödésre vonatkozó kutatások eredményei szerint 5-6 éves korban (Brüne és Brüne-Cohrs, 2006; Bíró, 
2002), mások szerint hétéves korban (Westby és Robinson, 2014) a gyermekek értik, hogy egy személynek lehetnek gondolatai egy másik személy gondolatairól, ezt nevezzük beágyazott mentálisállapot-tulajdonításnak.

\subsubsection{Az affektív tudatelmélet mérésére alkalmazott eljárások az egész mintán}

\subsubsection{1. $\quad$ Faces Teszt (Arcok Teszt)}

A Faces/Arcok Tesztben érzelmi állapotok azonosítása a vizsgálati személy feladata, azonban arcokról történik az érzelmek leolvasása, így affektív tudatelmélet mérésére alkalmazható (Faces Test, Baron-Cohen, Weelwright és Jollife, 1997). A tesztben egymás után 20 arckifejezést mutatunk a vizsgálati személynek. Minden archoz két érzelmet jelöl meg a teszt, ezek közül kell kiválasztani azt, hogy melyik illik a képen látható arckifejezésre. Az első tíz képen alapérzelmek (pl. boldogság, ijedtség, meglepődöttség), a második tíz képen bonyolult, komplex érzelmeket (pl. arrogáns, bűntudatos, flörtölő) kell felismerniük a résztvevőknek, melyek vélekedéseken, szándékokon alapulnak. A tesztben a jó válaszért egy pont jár, a helytelen jelzésekért nem jár pont, a teljesítmény szintén százalékos arányban fejezhetö ki.

\subsubsection{A komplex (kognitív és affektív) tudatelmélet mérésére alkalmazott eljárások az egész mintán}

\subsubsection{Faux Pas Felismerése Teszt-gyermek változat (5-11 éves korú vizsgálati személyek vizsgálatára)}

A Faux Pas Felismerése Teszt gyermek tesztváltozatát Baron-Cohen, Stone, Jones és Plaisted, (1999) alakították ki, első vizsgálataikban tipikus fejlődésű gyerekek, illetve autizmus-spektrumzavarral diagnosztizált személyekkel végzett kutatásaikban alkalmazták. A gyermek változat a 7 és 11 éves korú gyermekek tudatelméleti képességét méri, hiszen ebben az életkorban érik el azt a fejlettségi szintet, amikor képesek felismerni egy faux pas-t, azaz felismerni azt, hogy valaki nem szándékosan egy olyan információt mondott el, amit nem kellett volna, mert az bizalmas volt, vagy éppen sértő valaki számára (Gregory és mtsai, 2002). A faux pas jelentése ballépés, elszólás, ennek a felismerése pedig a tudatelmélet fejlődésének egyik állomása (7-11 éves korban), hiszen a tudatelméleti képesség egészen serdülőkorig, vagy akár ezen túl is folyamatosan fejlődik. A tesztben rövid történetek 
találhatók, melyekben az egyik szereplő egy véletlen elszólást produkál, mellyel megbántja a történetnek a másik szereplöjét, például a szomszéd hölgy kisfiúnak nézi a kislányt (1. melléklet). A tesztben szereplő történeteket egyéni beszámolók alapján válogatták ki, amikor is arra kértek embereket, hogy hozzanak példákat az életükben történt faux pas-kra. Mindezek után ezeket a történeteket 4 megítélővel értékeltették aszerint, hogy melyek azok, amik a faux pas legjobb példái lehetnek mind a 4 megítélő szerint. Így 10 faux pas-t tartalmazó történet került a tesztbe, illetve a későbbi vizsgálatok során 10 kontroll történetet is kialakítottak, melyek nem tartalmaznak faux pas-t (Baron-Cohen és mtsai, 1999). A történeteket a gyermekek számára az eredeti változatban magnóra vették, és lejátszották számukra, míg mi saját vizsgálatainkban, a felnőtt változathoz hasonlóan, felolvastuk a vizsgálati személyek számára.

A tesztben szereplő történeteket követően kérdések szerepelnek a történetben elhangzottakra vonatkozóan. Minden történethez négy kérdés kapcsolódik. Az első kérdés arra vonatkozik, hogy a vizsgálati személy felismeri-e, detektálja-e az elszólást. A faux pas-t tartalmazó történetek esetében a helyes válasz, vagyis az igen, 1 pontot ér. Amennyiben a vizsgálati személy az első kérdésre helyesen, azaz igennel válaszol, a második, vagyis az azonosításra vonatkozó kérdés tehető fel, melynek lényege, hogy a vizsgálati személy valóban felismeri-e, hogy ki követte el az elszólást, és mi volt az elszólás. A harmadik és a negyedik kérdés mindig a történet menetének megfelelően változik. A harmadik kérdés a megértésre vonatkozó kérdés, azaz azt méri fel, vajon a vizsgálati személy megértette-e magát a történetet, és megfelelően figyelte-e azt. A negyedik kérdés pedig arra vonatkozik, hogy a vizsgálati személy megérti-e, hogy az elszólás egy hamis vélekedés következménye volt, nem pedig egy rosszindulatú, szándékos elszólás. A történetekben 1 pontot kap a vizsgálati személy, ha a faux pas-t helyesen felismerte. Ahhoz, hogy a személy a faux pas-t felismerje, minden kérdésre helyes választ kell adnia (vagyis észrevenni, hogy valaki mondott olyat, amit nem kellett volna; azonosítani, hogy mi volt az, amit nem kellett volna mondani; az értelmező kérdésekre választ adni; illetve megérteni, hogy a faux pas egy hamis vélekedés következménye volt). Bármely kérdésre adott rossz válasz miatt 0 pontot kap az egész történetre (Baron-Cohen és mtsai, 1999). A teszt eredeti változatának tudomásunk szerint nincs magyar nyelvü megfelelője, magyar nyelvre fordítását elvégeztük, majd visszafordítottuk angolra, és összevetettük az eredeti változattal. 


\subsubsection{Faux Pas Felismerése Teszt-felnőtt változat (11-12 éves kortól alkalmazott eljárás)}

A Faux Pas Felismerése Teszt felnőtt tesztváltozatát Baron-Cohen és Stone (1998) alakították ki a tudatelmélet mérésére. A felnőtt változatot a gyermek Faux Pas Teszt alapján alakították ki (Stone, Baron-Cohen és Knight, 1998). A vizsgálatokban serdülökorú és felnőtt, illetve időskorú személyek is részt vesznek, emiatt a Faux Pas Felismerése Teszt felnőtt változatát alkalmaztuk ezekben az életkori csoportokban. A felnőtt változat elve, szerkezete és kivitelezése megegyezik a gyermek változatéval. A faux pas észlelésekor elvárható, hogy a vizsgálati személy felismerje, hogy különbség van a beszélő, és az őt hallgató tudása között, valamint felismerje a hallgató állításának érzelmi következményeit (Baron-Cohen és mtsai, 1999). A teszt az affektív mentális állapotok megértését is méri annak a képességnek a tesztelésével, hogy a személy felismeri-e, hogy a történet szereplője valami nem odaillő vagy sértő dolgot mondott. Továbbá a teszt méri még, hogy a személy érti-e, hogy a történet szereplője hamis vélekedést mutat, valamint ezen kívül méri még az elszólással kapcsolatban a véletlenszerüség, a nem szándékosság megértését, annak megállapításával, hogy a személy érti-e, hogy a faux pas nem szándékosan hangzott el (Stone és mtsai, 2003).

A mérőeszközben a faux pas felismerése, nem annak produkálása a cél. A teszt 20 történetből épül fel, melyböl 10 tartalmaz faux pas-t, például: a szomszéd hölgy fiúnak nézi a három éves kislányt (1. mellékletben). A történeteket a vizsgálatvezető egyenként olvassa fel a vizsgálati személynek, aki a saját példányán is folyamatosan követheti azokat. Ez a példány a vizsgálati személy előtt van akkor is, amikor a történethez kapcsolódó tesztkérdések hangzanak el. Az egyes történetek felolvasása után a vizsgálatvezető az elszólás detektálására irányuló kérdést tesz fel, ha a személy válasza igen, további kérdések következnek. A második kérdés az elszólást elkövető személy azonosítására szolgál, ha erre a kérdésre a személy helyesen válaszol, azt jelenti, hogy helyesen ismerte fel a faux pas-t. Ezután két kérdés következik: „Miért nem kellett volna ennek az illetőnek azt mondania, amit mondott?” - azt méri, hogy a személy megértette, hogy a másik szereplöt megbántották. A második kérdés: „Mit gondol, miért mondta ezt?” - azt méri, hogy a személy megértette, hogy az elszólás nem volt szándékos. Tehát a fenti kérdések tartoznak az egyes történetekhez, akkor, ha a személy felismerte, hogy a történet tartalmaz elszólást. Ezen kérdések után ellenőrző kérdéseket teszünk fel a vizsgálati személynek, melyek arra irányulnak, hogy a személy 
megértette-e a történetet, vagyis a történet bizonyos részleteire kérdez rá, például „Mit adott Zsanett nászajándékba Annának?”. Ha a személy a történetet követő első kérdésre nemmel válaszol, akkor a faux pas kérdéseket kihagyva, az ellenőrző kérdések következnek. A személy válaszait a vizsgálatvezető lejegyzi, a vizsgálat kétszemélyes helyzetben történik (Stone és mtsai, 2003).

A teszt értékelése egy kritériumrendszer alapján történik. A pontozás során a szerzők szerint a józan észre kell hagyatkoznunk, természetesen ez a teljesen objektív értékelést nehezítheti. Külön szükséges értékelni az elszólást tartalmazó (továbbiakban Faux Pas történetek) és a faux pas-t nem tartalmazó (továbbiakban Kontroll) történeteket. A Faux Pas történetek: 2, 4, 7, 11, 12, 13, 14, 15, 16, 18; a Kontrolltörténetek: 1, 3, 5, 6, 8, 9, 10, 17, 19, 20.

A Kontrolltörténetek értékelésekor az első kérdésre („Mondott-e bárki valami olyat, amit nem kellett volna mondania? Mondott bárki valami nem odaillőt?”) adott ,igen” választ követően ugyan feltesszük a további kérdéseket is, azonban 0 pontot adunk a történetre, hiszen annak ellenére, hogy nem volt a történetben faux pas, a személy mégis annak vélte. Ha erre a kérdésre „nem”-mel válaszol, 2 pontot kap a vizsgálati személy. A 10 kontroll történetre összesen 20 pontot kaphat a személy.

A Faux Pas történetek értékelése során az első kérdésre („Mondott-e bárki valami olyat, amit nem kellett volna mondania? Mondott bárki valami nem odaillőt?”) adott „,nem” válasz esetén 0 pont adható, hiszen nem ismerte fel az elszólást a személy. Ha az 1. kérdésre „,igen” választ kapunk, 1 pontot kap a vizsgálati személy. Ez esetben a további kérdések is értékelésre kerülnek. Az egyes kérdésekre adott helyes válaszok 1-1 pontot érnek. A 2. kérdésre („Ki mondott olyat, amit nem kellett volna mondania?”) akkor adunk pontot, ha a személy helyesen megnevezte a faux pas-t elkövető személyt. Elfogadható a személy körülírása is, például a 7. történetben a név (Marika) helyett elfogadható a szomszéd hölgy válasz is (1. mellékletben). Ha a személy az 1. kérdésre „nem” választ adott, ezt a kérdést nem tesszük fel neki. A 3. kérdésre („Miért nem kellett volna ennek az illetőnek azt mondania, amit mondott?") akkor adunk 1 pontot, ha a személy válasza arra utal, hogy felismerte a faux pas-t, a válaszában azonban nem kell, hogy mentális állapotot expliciten említsen. Például elfogadható válasz: „azért, mert János nagyon beteg” vagy „,nem illik egy új lakásba belépve kritizálni azt, sosem lehet tudni, hogy ki vásárolta a berendezést”. Erre a kérdésre adott válasz akkor helytelen, ha abból nem derül ki, hogy a személy megértette a faux pas-t, és a belőle 
származó sértést. Például: „Nem illik elkésni az értekezletekről” (11. történet válaszakor nem említi az oda nem illő viccet). A 4. kérdésre („Mit gondol, miért mondta ezt?”) minden olyan ésszerü válasz elfogadható, amelyből kiderül, hogy a faux pas-t megértette a személy. Amennyiben a válasz azt mutatja, hogy a személy megértette, hogy a történet szereplői közül valaki nem tudott valamit, vagy nem volt tisztában valamivel, még akkor is, ha válaszában nem említ expliciten mentális állapotokat. A választ akkor értékeljük helytelennek (0 pont), ha abból az tűnik ki, hogy a történet szereplőjének elszólása szándékos volt. Például: „Csaba felvágni akart Kriszti előtt, mert nagyképü” (nem említi, hogy Csaba nem tudhatta, hogy Kriszti is benevezett a versenybe). Ha a válasz „nem tudom”, akkor is 0 pontot adunk. Az 5. kérdés („Vajon X tudta, h Y is...?”) arra vonatkozik, hogy a személy észleli-e, hogy az elszólás nem szándékos volt. A pontozás eszerint történik, vagyis ha a személy válaszából kiderül, hogy nem volt szándékos az elszólás, 1 pontot adunk. Például: „Nem, Marika nem tudta, hogy Szilvi lány”. Ha szándékosnak véli a személy, akkor 0 pontot kap. A 6. kérdés („Vajon hogyan érezhette magát Y?”) arra vonatkozik, hogy a személy megértette-e, hogy az elszólás megbánthatta a másik szereplőt, azaz a szereplők iránti empátiára vonatkozik, helyes a válasz, ha abból tükröződik a fájdalom, düh, zavarodottság és csalódottság, a történetnek megfelelően. Az ellenőrző kérdéseket (7. és 8.) minden történet után felteszi a vizsgálatvezető - függetlenül az 1. kérdésre adott válaszoktól. Ebből tudhatjuk meg, hogy a személy értette-e a történetet, valamint a válaszai esetleg annak voltak-e köszönhetök, hogy összekavarta a szereplőket vagy a párbeszédeket. Ezekre adott helye válaszok egyenként 1 pontot érnek és külön kezelendők a többi pontszámtól. Így tehát a Faux Pas történetekre összesen 60 pont adható (Stone és mtsai, 1998).

Mindezek alapján a vizsgálati személy három pontszámmal rendelkezik, melyből egy az ellenőrző kérdésekre adott pontszámok összege. Ezt akkor szükséges elemezni, ha hibás válaszokat is adott a személy, például összekeverte a tényeket. Ebben az esetben az ehhez kapcsolódó történetre adott választ nem értékeljük, és az értékelést az elért összpontszám százalékos arányában végezzük (pl. nem 60-hoz, hanem 54-hez viszonyítjuk a pontszámát). A további két pontszám pedig a Faux Pas történetekre adott összpontszám és a Kontroll történetekre adott összpontszám, melyekből a tudatelméleti hibák, különbségek következtethetök ki. 
A Faux Pas Felismerése Teszt magyarra fordítását korábbi kutatásom keretében készítettem el, melyet visszafordítás után összevetettünk az eredeti angol változattal. Az angol változatban szereplő neveket gyakori magyar nevekkel helyettesítettem, ahol azonban volt az angol névnek megfelelő magyar személynév, azt alkalmaztam (pl. John-János).

\subsection{A kognitív funkciók mérésére alkalmazott eljárások}

\subsubsection{A munkamemória mérése}

Számterjedelem teszt (Digit Span)

A verbális munkamemória mérésére a számterjedelem tesztet alkalmaztuk, melynek során a vizsgálati személynek egy adott, folyamatosan egy elemmel bővülő számsorozatot kell visszamondania azonos sorrendben. A vizsgálat vezetőjének egyenként kell felolvasnia a számsorokat, egy másodperces szünetet hagyva a számok között. A vizsgált személy emlékezeti terjedelmét az a sorozathosszúság jelöli, amiből legalább kettőt helyesen vissza tud mondani (Racsmány, és mtsai, 2005).

\section{Forditott számterjedelem teszt (Backward Digit Span)}

A komplex munkamemória-kapacitás mérésére a fordított számterjedelem tesztben a számsorozatokat a vizsgálat vezetőjének egyenként, egy másodperces szüneteket hagyva kell felolvasnia, a vizsgált személynek pedig fordított sorrendben kell megismételnie. A személy eredményét az a sorozathosszúság adja, amiből legalább kettőt helyesen meg tud ismételni (Conway, Kane, Bunting, Hambrick, Wilhelm és Engle, 2005; Hutton és Towse, 2001).

\section{Hallási mondatterjedelem teszt (Listening Span)}

A komplex munkamemória-kapacitás mérésére. A hallási mondatterjedelem tesztben a vizsgálatvezető hangosan felolvassa a mondatokat, melyekről meg kell állapítani, hogy igaz vagy hamis. Ezután a mondatok utolsó szavait kell sorrendben visszamondani. A teszt három sorozatból áll, ezek átlaga adja a terjedelmi értéket (Janacsek, Tánczos, Mészáros és Németh, 2009). 


\section{Számlálási terjedelem teszt (Counting Span)}

A vizsgálati személynek a képernyőn látható geometriai formák közül hangosan meg kell számolnia a sötétkék köröket, a végeredményt pedig megjegyezni, majd sorrendben visszamondani a megjegyzett végeredményeket. Egyre több számolás végeredményét kell fejben tartani. A három sorozat átlaga adja a végső terjedelmi értéket, amely maximálisan 6 lehet, mivel hat elemből áll egy sorozaton belül a leghosszabb számsorozat (Case, Kurland és Goldberg, 1982).

\subsection{A társas pozíció mérése iskoláskorú gyermekek körében}

\subsubsection{A szociális státusz mérése szociometriai módszerrel}

A vizsgálatunkban az egyszerü választásos szociometriai módszert alkalmaztuk a csoportban elfoglalt pozíció mérésére az iskolai mintán (Banerjee és Watling, 2005; Banerjee, Watling és Caputi, 2011). A szociometriai módszer alkalmazása során megkértük a vizsgálati személyeket, hogy nevezzenek meg 3 olyan személyt az osztályban, akikkel szívesen töltenek együtt időt, illetve 3 olyan személyt, akikkel nem szívesen töltenek együtt időt. Vagyis pozitív és negatív választásokat kértünk a gyermekektől. A szociometriai pozíció kialakítását három eltérő módszerrel végeztük.

(1) Az első módszer a legegyszerübb módon jelöli ki a csoportokat. Az egyes gyermekekre adott pozitív választások és negatív választások arányában képezünk csoportokat. Mindez azt jelenti, hogy a népszerü csoportba tartoztak azok a gyerekek, akiknek több pozitív választásuk volt, míg az ambivalens gyerekek ugyanannyi pozitív, mint negatív választással rendelkeztek, továbbá az elutasított gyermekek csoportjába kerültek azok, akik több negatív, mint pozitív választást kaptak az osztálytársaktól.

(2) A második elemzési módszert Banerjee és Watling (2005) alkalmazták kutatásukban, változatlanul ugyanezt az értékelési rendszert alkalmazzuk másodikként. Alapja a 3 pozitív illetve 3 negatív választás, ezek számát összegezzük minden gyermek esetében az adott osztályban. Ezt követően mind a pozitív, mind a negatív választások standard értékeit (Z-score) hozzuk létre, és a továbbiakban ezekkel a standard értékekkel 
számolunk. Mindezek után létrehozunk két újabb változót, a társas preferencia (social preference) és a társas befolyás (social impact) változókat. A társas preferencia változó a standardizált pozitív és negatív választások különbsége, a társas befolyás változó pedig a két standardizált változó összeadásából adódik. Az említett változók értékei alapján öt szociometriai csoportot tudunk létrehozni. Így népszerü, elutasított, ambivalens, elhanyagolt és semleges szociometriai státuszú csoportokat tudunk kialakítani. Az egyes csoportok számítási módjait a 7. táblázatban ismertetjük, Banarjee és Watling (2005) alapján.

7. táblázat: A szociometriai csoportok kialakításának módja Banerjee és Watling (2005) alapján

\begin{tabular}{l|c|l|l}
\hline $\begin{array}{c}\text { Szociometriai } \\
\text { csoportok }\end{array}$ & \multicolumn{3}{c}{ Változók értékei } \\
\hline \hline Népszerü & társas preferencia $>1$ & pozitív választás $>0$ & negatív választás $<0$ \\
\hline Elutasitott & társas preferencia $<-1$ & pozitív választás $<0$ & negatív választás $>0$ \\
\hline Ambivalens & társas befolyás $>1$ & pozitív választás $>0$ & negatív választás $>0$ \\
\hline Elhanyagolt & társas befolyás $<-1$ & pozitív választás $<0$ & negatív választás $<0$ \\
\hline Semleges & $-1<$ társas preferencia $<1$ & $-1<$ társas befolyás $<1$ \\
\hline
\end{tabular}

(3) A harmadik értékelési szempont nem csoportokat hoz létre az osztályon belül, azaz nem kategorizál, hanem folytonos változókat alakít ki, melyet Banerjee, Watling és Caputi (2011) alkalmazott a tudatelmélet és a társas pozíció kapcsolatának vizsgálatában. A változók kialakításának alapja a pozitív és a negatív választások standard értéke. Azaz a standardizált pozitív választások a társak közötti elfogadottságot jelzi, míg a standardizált negatív választások az osztályban a társak közötti elutasítottságot jelzi (Banerjee, Watling és Caputi, 2011). 


\subsection{A vizsgálatsorozatban alkalmazott méröeszközök felvétele}

A vizsgálatsorozatban a mérőeszközök felvételére iskoláskorú vizsgálati személyek esetében az intézményben külön szobában, míg a felnőtt vizsgálati személyek esetében nyugodt körülmények között került sor. Az egyes vizsgálatokban alkalmazott mérőeszközcsomagok kétszemélyes helyzetben kerültek felvételre, előzetesen felkészített kutatási asszisztensek segítségével. A kutatásban alkalmazott tesztek nem invazív eljárások, tisztán viselkedéses módszerek, melyek a vizsgálati személyre semmilyen káros következménnyel nem járnak. A mérőeszközcsomagok felvétele a vizsgálati személyek életkorától, aktuális állapotától és terhelhetőségétől függően 4590 percet vett igénybe, igény szerint természetesen megszakítható volt vagy két ülésben történt az adatfelvétel, az etikai kockázatok minimalizálása érdekében. A tesztek alkalmazása során a vizsgálatvezető olvasta fel a tesztek instrukcióit és feladatait, majd a vizsgálati személy azonosítójával ellátott jegyzőkönyvre vezette fel a szó szerinti válaszokat. Az adatok kódolása, rögzítése az egyes tesztek értékelési és pontozási rendszere alapján történt. A vizsgálatban használt jegyzőkönyveket bizalmasan kezeltük, a kutatásban nem illetékes személyek számára nem hozzáferhető. 


\section{AZ EMPIRIKUS VIZSGÁLAT EREDMÉNYEI}

\subsection{A tudatelméleti képesség életkori változásainak és a tudatelméleti tesztek közötti kapcsolatok eredményének ismertetése}

$\mathrm{Az}$ első vizsgálatban arra kerestük a választ, hogy a tudatelméleti tesztekkel mért teljesítményben kimutathatók-e életkori különbségek, és amennyiben igen, milyen irányúak ezek a különbségek. A korábbi kutatások alapján tehát azt várjuk, hogy a Faux Pas Felismerése Teszt gyermek tesztváltozatával mért, 5-11 éves korosztályú almintánkban az 5-6 éves korosztály teljesít a legalacsonyabb színvonalon, majd a 7-8, a 9, a 10 és a 11 éves gyerekek teljesítménye szignifikánsan magasabb. Hasonlóan, a Faux Pas Felismerése Teszt felnőtt tesztváltozatát alkalmazva azt feltételezzük, hogy 11 éves korban a legalacsonyabb a teljesítmény, majd a fiatal felnőttkorban növekszik, illetve a legidősebb, 60-75 éves korosztályban lesz a legalacsonyabb a tudatelméleti teljesítmény.

A tudatelmélet működését egyrészt a Faux Pas Felismerése Teszttel mértük, a fiatal korcsoportokban a gyermek változatával (Baron-Cohen és mtsai, 1999), a serdülő és felnőtt korosztályban pedig a felnőtt változatával (Stone és mtsai, 1998; Gál, Egyed, Pászthy és Németh, 2011; Gál, Katona, Janacsek és Németh, 2014). Az affektív tudatelméleti müködés mérését a Faces Tesztttel végeztük (Baron-Cohen, Weelwright és Jollife, 1997), ezen belül az alapérzelmek felismerése tekintetében nem várunk jelentös életkori különbségeket a csoportok között, míg a komplex, azaz vélekedéseken alapuló érzelmek tekintetében már várunk életkorral növekvő teljesítményt, ugyanakkor az időskorban megjelenő szignifikáns teljesítményromlást is feltételezzük. A vizsgálatunkba bevont 299 személyt két korosztályi csoportra bontottuk módszertani okok miatt, hiszen a Faux Pas Felismerése Teszt gyermek változata 7-11 éves korban méri a tudatelmélet müködést (Baron-Cohen és mtsai, 1999), míg a 11-7 éves életkorú almintában a felnőtt változatot alkalmaztuk. Eredményeinket a továbbiakban a két korcsoporti almintának megfelelően ismertetjük. 


\subsubsection{A tudatelméleti képesség életkori különbségei az 5-11 éves korú mintában}

Az adatok elemzéséhez a tesztek pontozási rendszerét, illetve statisztikai eljárásokat alkalmaztunk. Az életkori csoportok teljesítményének összehasonlítását varianciaanalízis módszerével végeztük, a tudatelméleti tesztek közötti kapcsolatokat pedig korrelációs együtthatóval ellenőriztük.

\subsubsection{A Faux Pas Felismerése Teszt gyermek tesztváltozatának életkori különbségei}

A Faux Pas Felismerése Teszt eredeti pontozási rendszerét a 9.1.3.1. és 9.1.3.2. fejezetben ismertettük, eszerint minden egyes, elszólást tartalmazó történetre 1 pont adható abban az esetben, ha minden kérdésre helyesen válaszol a vizsgálati személy (Baron-Cohen és mtsai, 1999). Eszerint a pontozási rendszer szerint az általunk kialakított 5 életkori csoportban az elszólások felismerésének életkori különbségeit variancaanalízissel ellenőriztük. A statisztikai eljárás alapján megállapítható, hogy az 5 életkori csoport között tendencia jellegü különbség található $(\mathrm{F}(4 ; 167)=2,315, \mathrm{p}=0,059)$. Az utóelemzés szerint az 5-6 évesek korcsoportja minden további korcsoporthoz képest szignifikánsan alacsonyabb teljesítményt nyújt az elszólások felismerésében, mint a 7-8 ( $\mathrm{p}=0,014)$, a $9(\mathrm{p}=0,009)$, a $10(\mathrm{p}=0,009)$ és a 11 évesek $(\mathrm{p}=0,011)$ korcsoportja. Ugyanakkor megállapítható, hogy a 7-8 évesek, a 9, a 10, és a 11 évesek korcsoportja egymástól szignifikánsan nem különbözik (minden p>0,05). Vagyis a Faux Pas Felismerése Teszten elért összteljesítmény tekintetében megállapítható, hogy a legfiatalabb életkori csoportba tartozó gyerekek teljesítenek a legalacsonyabb színvonalon, minden más korcsoporthoz képest, azonban a 7-8 éves korosztálynál és a náluk idősebbeknél már nem változik jelentős mértékben a gyermekek teljesítménye. Az eredményeket a 4. ábrán mutatjuk be. 


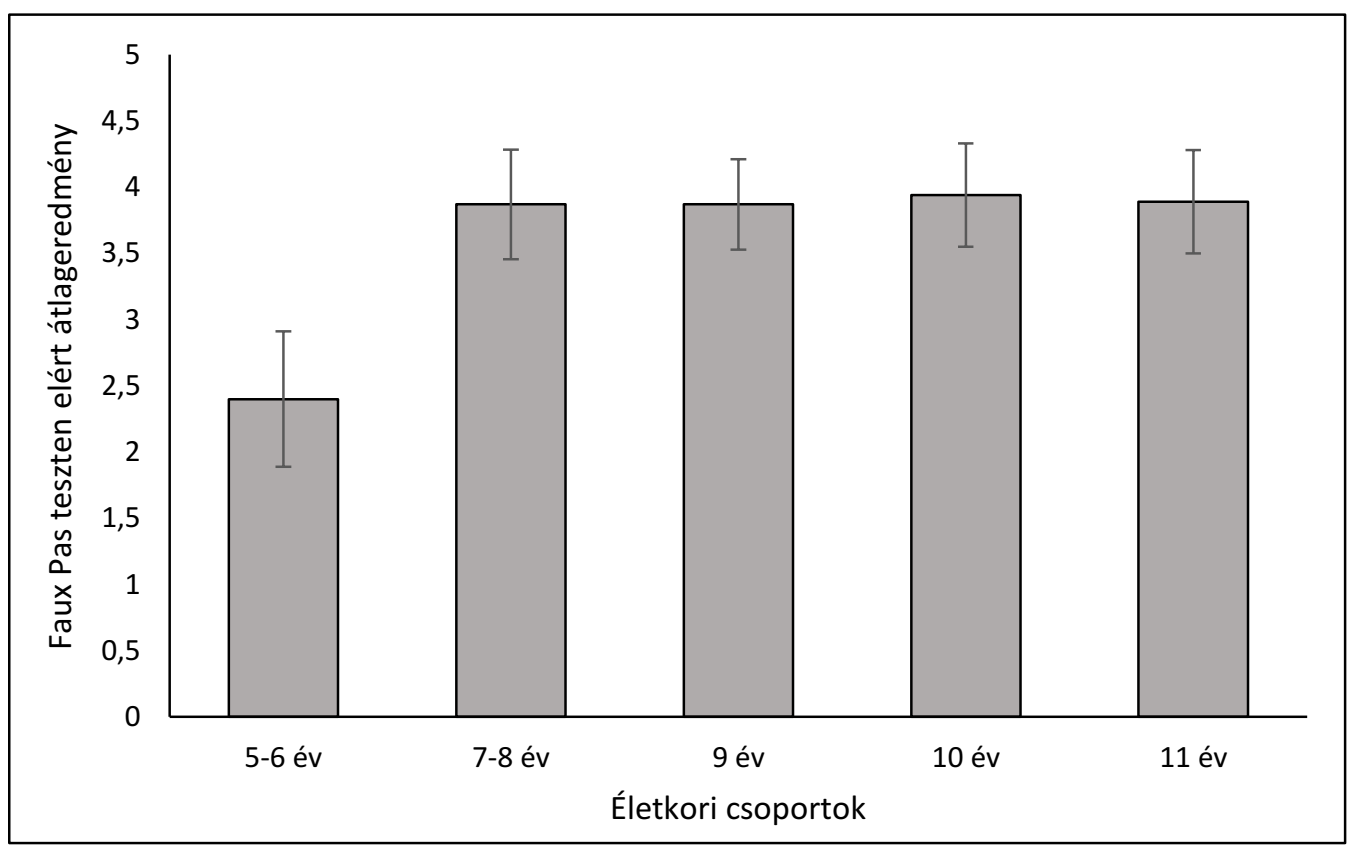

4.ábra: A Faux Pas Felismerése Teszt gyermek tesztváltozatán nyújtott teljesítmény életkori különbségei 5 éves kortól 11 éves korig $(F(4 ; 167)=2,315, p=0,059)$

Az eredetileg kialakított értékelési rendszer mellett azonban saját vizsgálatainkban ellenőriztük az elszólás detektálására, a történet megértésére és a hamis vélekedés megértésére vonatkozó kérdésekre adott válaszok átlagértékeit is. Így három változót elemeztünk, az elszólás detektálását, a történet megértését és a hamis vélekedés megértését.

Az elszólás detektálása kapcsán, vagyis arra a kérdésre, hogy elhangzott-e a történetben valami furcsa, oda nem illő kapott helyes, vagyis az igen válaszokat is összehasonlítottuk a csoportokban variancianaalízis segítségével. Az eredmények szerint nincs szignifikáns csoportfőhatás az elszólások detektálásának teljesítményében $(\mathrm{F}(4 ; 167)=1,624, \mathrm{p}=0,17)$, azaz az életkori csoportok között nem mutatható ki jelentős különbség annak tekintetében, hogy képesek-e helyesen észlelni, hogy valaki elszólást követett el a történetben. Az elszólások felismerésének átlagértékei az egyes csoportokban 6,4 és 7,6 között mozogtak, ami a véletlen szintjénél nagyobb, vagyis feltehetően nem pusztán találgatás alapján adtak választ a vizsgálati személyek. Továbbá érdekes eredmény, hogy a legfiatalabb korosztály is a véletlen szintje felett teljesített, ami jelezheti azt is, hogy a gyerekek már 5-6 éves korban képesek felismerni, hogy valaki elkövetett egy elszólást, 
azonban ennek indoklásában, illetve a mögöttes szándékok kikövetkeztetésében akár lehetnek nehézségeik. Az elszólás szándékosságának, illetve véletlenszerüségének tulajdonítását a tesztben a történeteket követő negyedik kérdéssel ellenőrizhetjük. A negyedik kérdés arra vonatkozik, hogy a személy megértette-e, hogy az elszólást elkövető személy hamis vélekedése miatt történt az elszólás, tehát nem szándékosan, rosszindulatból követte el a faux pas-t. A negyedik kérdésre adott helyes válaszok átlagértékeinek összehasonlítását variancianalízissel végeztük, ennek eredményei szerint szignifikáns csoportfőhatás mutatható ki $(\mathrm{F}(4 ; 166)=6,379, \mathrm{p}<0,001)$. A legfiatalabb csoport alacsonyabb teljesítményt nyújtott a 9 évesekhez képest ( $\mathrm{p}=0,056$ ), a 7-8 évesek csoportja szignifikánsan magasabb teljesítményt nyújt azonban a $10(\mathrm{p}=0,045)$ és a 11 éves gyerekek $(\mathrm{p}=0,001)$ csoportjához képest. Továbbá a 9 évesek teljesítménye is szignifikánsan magasabb a $10(\mathrm{p}=0,001)$ és a 11 éves $(\mathrm{p}<0,001)$ gyerekek eredményeihez képest. Ezek alapján tehát azt láthatjuk, hogy az elszólás mögötti hamis vélekedés tulajdonítás az 5-6 évesektől a 9 éves korosztályig egyre magasabb teljesítményt jelez, ugyanakkor a 10 és a 11 éves korosztályban ez a teljesítmény alacsonyabb szintüvé válik. Ennek magyarázatában fontos lehet annak vizsgálata, hogy valójában mennyire érthették meg, mennyire figyeltek a gyerekek az adott történetekre, melyet a történeteket követő harmadik kérdésre adott helyes válaszokkal ellenőrizhetünk. A varianciaanalízis eredményei alapján ez esetben is szignifikáns a csoportfőhatás $(\mathrm{F}(4 ; 167)=4,697, \mathrm{p}=0,001)$. Az utóelemzés szerint az 5-6 évesek a 7-8 ( $\mathrm{p}=0,001)$, a 9 $(\mathrm{p}<0,001)$ és a 11 évesekhez $(\mathrm{p}=0,023)$ képest szignifikánsan alacsonyabb színvonalon teljesítenek. Ugyanakkor e kérdésben is a 9 évesek teljesítménye a legmagasabb a korcsoportok között, azonban csak az 5-6 $(\mathrm{p}<0,001)$ és a 10 évesek $(\mathrm{p}=0,011)$ teljesítményétől tér el szignifikánsan. Vagyis elmondható, hogy a történetek megértésében, a történésekre való figyelem tekintetében a 9 évesek átlageredménye emelkedik ki a többi korcsoport közül, vagyis az elszólások mögötti hamis vélekedés megértésének 9 évesek esetében kimutatható magas eredménye akár a jobb történetre való odafigyeléssel állhat összhangban. Az is látható azonban, hogy a 10 és 11 éves gyerekek történet megértése magasabb színvonalú az 5-6 éves gyerekekéhez képest, azaz az elszólás mögötti hamis vélekedés megértésének alacsonyabb színvonala nem rosszabb történetmegértési teljesítmény oka lehet az idősebb életkori csoportban, sokkal inkább a hamis vélekedés megértésének automatizmusa okozhatja a teljesítmény alacsonyabb színvonalát ebben a korosztályban. A szakirodalmi adatok szerint a faux pas megértésének képessége 9-11 éves korban alakul ki (Baron-Cohen és mtsai, 1999), 
saját vizsgálataink eredménye szerint a mintánkba tartozó 7-8 éves gyerekek teljesítményéhez hasonlóan teljesítenek jelen vizsgálatban részt vevő 9-10-11 éves gyerekek a teszt értékelésének eredeti változata szerint. Ugyanakkor az egyes kérdések elemzése arra világít rá, hogy vizsgálatunkban már az 5-6 éves gyerekek is a véletlen szintje fölött képesek detektálni (de nem feltétlenül megérteni) a társas helyzetben elkövetett elszólásokat. Illetve az elszólások mögötti hamis vélekedés tulajdonítás a vizsgált 9 éves gyerekek körében a legmagasabb az öt életkori csoport között.

8. táblázat: Átlageredmények a tudatelméleti teszteken az 5-11 éves korosztályban

\begin{tabular}{|c|c|c|c|c|c|c|}
\hline \multirow[b]{2}{*}{$\begin{array}{l}\text { ToM } \\
\text { teljesítmény }\end{array}$} & 5-6 év & $7-8$ év & 9 év & 10 év & 11 év & \multirow[b]{2}{*}{$\mathrm{F}(\mathrm{p})$} \\
\hline & $\begin{array}{c}\text { Átlag } \\
\text { (szórás) } \\
\end{array}$ & $\begin{array}{c}\text { Átlag } \\
\text { (szórás) } \\
\end{array}$ & $\begin{array}{c}\text { Átlag } \\
\text { (szórás) } \\
\end{array}$ & $\begin{array}{c}\text { Átlag } \\
\text { (szórás) }\end{array}$ & $\begin{array}{c}\text { Átlag } \\
\text { (szórás) } \\
\end{array}$ & \\
\hline $\begin{array}{l}\text { Faux Pas } \\
\text { Felismerése } \\
\text { Teszt } \\
\text { összpontszám }\end{array}$ & $2,24(0,51)$ & $3,86(0,41)$ & $3,87(0,34)$ & $3,94(0,39)$ & $3,89(0,39)$ & $\begin{array}{c}\mathrm{F}(4 ; 167)=2,315 \\
\mathrm{p}=0,059\end{array}$ \\
\hline $\begin{array}{l}\text { Faux Pas } \\
\text { Felismerése } \\
\text { Teszt } \\
\text { elszólás } \\
\text { detektálása } \\
\end{array}$ & $6,9(0,48)$ & $7,25(0,39)$ & $7,64(0,32)$ & $6,42(0,37)$ & $7,11(0,37)$ & $\begin{array}{c}F(4 ; 167)=1,624 \\
p=0,17\end{array}$ \\
\hline $\begin{array}{l}\text { Faux Pas } \\
\text { Felismerése } \\
\text { Teszt } \\
\text { megértés }\end{array}$ & $6,19(0,44)$ & $8,09(0,36)$ & $8,21(0,29)$ & $7,06(0,34)$ & $7,47(0,34)$ & $\begin{array}{c}F(4 ; 167)=4,697 \\
p=0,001\end{array}$ \\
\hline $\begin{array}{l}\text { Faux Pas } \\
\text { Felismerése } \\
\text { Teszt }- \text { hamis } \\
\text { vélekedés }\end{array}$ & $6,9(0,51)$ & $7,53(0,41)$ & $8,09(0,34)$ & $6,39(0,39)$ & $5,7(0,39)$ & $\begin{array}{c}F(4 ; 166)=6,379 \\
p<0,001\end{array}$ \\
\hline $\begin{array}{l}\text { Faces Teszt - } \\
\text { összpontszám }\end{array}$ & $15,33(0,37)$ & $15,03(0,3)$ & $16,1(0,25)$ & $15,7(0,29)$ & $16,75(0,29)$ & $\begin{array}{c}\mathrm{F}(4 ; 167)=5,059 \\
\mathrm{p}=0,001\end{array}$ \\
\hline $\begin{array}{l}\text { Faces Teszt - } \\
\text { alapérzelmek }\end{array}$ & $9,2(0,21)$ & $8,3(0,17)$ & $8,6(0,14)$ & $8,6(0,16)$ & $8,9(0,16)$ & $\begin{array}{c}\mathrm{F}(4 ; 167)=3,13 \\
\mathrm{p}=0,016\end{array}$ \\
\hline $\begin{array}{l}\text { Faces Teszt - } \\
\text { komplex } \\
\text { érzelmek }\end{array}$ & $6,14(0,28)$ & $6,75(0,23)$ & $7,45(0,19)$ & $7,1(0,22)$ & $7,89(0,22)$ & $\begin{array}{c}F(4 ; 167)=7,545 \\
p<0,001\end{array}$ \\
\hline
\end{tabular}

Feltételeztük továbbá, hogy a másodfokú hamisvélekedés-tesztet teljesítő gyerekek jobb eredményeket produkálnak a Faux Pas Felismerése Teszten a sikertelenül teljesítő gyerekekhez képest. Az adatok elemzését az egész mintán és életkori csoportok esetében is elvégeztük, variancianalízis alkalmazásával. Az eredmények arra utalnak, hogy azok a 
gyerekek, akik sikeresen teljesítik a másodfokú hamisvélekedés-tesztet, szignifikánsan jobb eredményt érnek el a Faux Pas Felismerése Teszten $(F(1 ; 162)=13,094, p<0,001)$, ugyanakkor az életkori csoportokon belül ezt a különbséget nem tudtuk kimutatni (életkori csoport $\mathrm{X}$ sikeres/sikertelen másodfokú hamisvélekedés-teszt $\mathrm{F}(4 ; 162)=1,363, \mathrm{p}=0,243)$. A Faux Pas Felismerése Teszt negyedik kérdésére, vagyis az elszólás hátterében álló hamis vélekedések megértésére adott válaszok esetében is elvégeztük az elemzést, csoportosítva mintánkat aszerint, hogy sikeresen vagy sikertelenül oldották-e meg a másodfokú hamisvélekedéstesztet. Az eredmények szerint azok a gyerekek, akik sikeresen teljesítik a másodfokú hamisvélekedés-tesztet, szignifikánsan jobban képesek felismerni az elszólás mögötti hamis vélekedést $(\mathrm{F}(1 ; 161)=15,54, \mathrm{p}<0,001)$, ugyanakkor az életkori csoportokon belül ezt a különbséget nem tudtuk kimutatni (életkori csoport $\mathrm{X}$ sikeres/sikertelen másodfokú hamisvélekedés-teszt $\mathrm{F}(4 ; 161)=1,398, \mathrm{p}=0,237)$. Azaz a másodfokú hamisvélekedés-teszt sikeres megoldása - ami a faux pas megértéséhez képest egy korábbi fejlődési állomásnak tekinthető - sikeresebb faux pas megértést eredményez az általunk vizsgált 5-11 éves korosztályban. Mindez igazolja azt, hogy azok a tipikus fejlődésü gyerekek, akik képesek megoldani az első-, illetve a másodfokú hamisvélekedés-teszteket, nagyobb valószínűséggel képesek megoldani egy bonyolultabb, összetettebb tudatelméleti képességet igénylő feladatot, vagyis a Faux Pas Felismerése Tesztet (Baron-Cohen és mtsai, 1999).

\subsubsection{A Faces Teszt életkori különbségei az 5-11 éves korosztályban}

Feltételezéseink szerint míg a Faces Teszt alapérzelmek felismerése tekintetében nem, addig a komplex érzelmek tekintetében már észlelhetünk életkori különbségeket az 5-11 éves korosztályban. Ennek a feltételezésnek a hátterében az áll, hogy az alapérzelmek kifejezése és felismerése már a pre-tudatelméleti (éntudat kialakulása) időszakban is megjelenik, például a boldog, szomorú, dühös, félelem érzelmeket hároméves korban képesek összekapcsolni a gyerekek a fotókon látható arcokkal (Westby és Robinson, 2014, 1. 3.2. fejezet).

Az eredményeink arra utalnak, hogy a Faces Tesztben a 10 alapérzelmet megjelenítő fotón az érzelmek tulajdonítása során szignifikáns életkori csoportfőhatás mutatkozik $(\mathrm{F}(4 ; 167)=3,131, \mathrm{p}=0,016)$. Fontos megemlíteni azonban, hogy az alapérzelmek tulajdonítása tekintetében az átlagértékek 8,2 és 9,1 pontszámok között mozogtak, feltehetően plafonhatás jelenik meg a teszt ezen részében, vagyis emiatt a csoportfőhatásra vonatkozó eredményeink 
korlátozottan értelmezhetők, és nem feltétlenül vonhatók le érvényes következtetések az életkori különbségekre vonatkozóan.

A Faces Teszt komplex érzelmeinek tulajdonítását tekintve szintén szignifikáns életkori csoportfőhatást tudunk kimutatni $(\mathrm{F}(4 ; 167)=7,545, \mathrm{p}<0,000)$, azonban a komplex érzelmekre adott válaszok átlagai már nem jeleznek plafonhatást, az egész mintában 6,1 és 7,9 átlagpontszám között mozognak. Az utóelemzés szerint teljesítménynövekedés mutatható ki az egyes életkori csoportok esetében, ugyanakkor az 5-6 és a 7-8 évesek közötti, illetve a 9 és 10, 11 évesek, valamint a 7-8 és 10 közötti teljesítménykülönbség nem szignifikáns. A 10 éves gyerekek teljesítménye csak az 5-6 és a 11 éves gyerekek teljesítményétől különbözik jelentősen. Az eredményeket az 5. ábrán szemléltetjük.

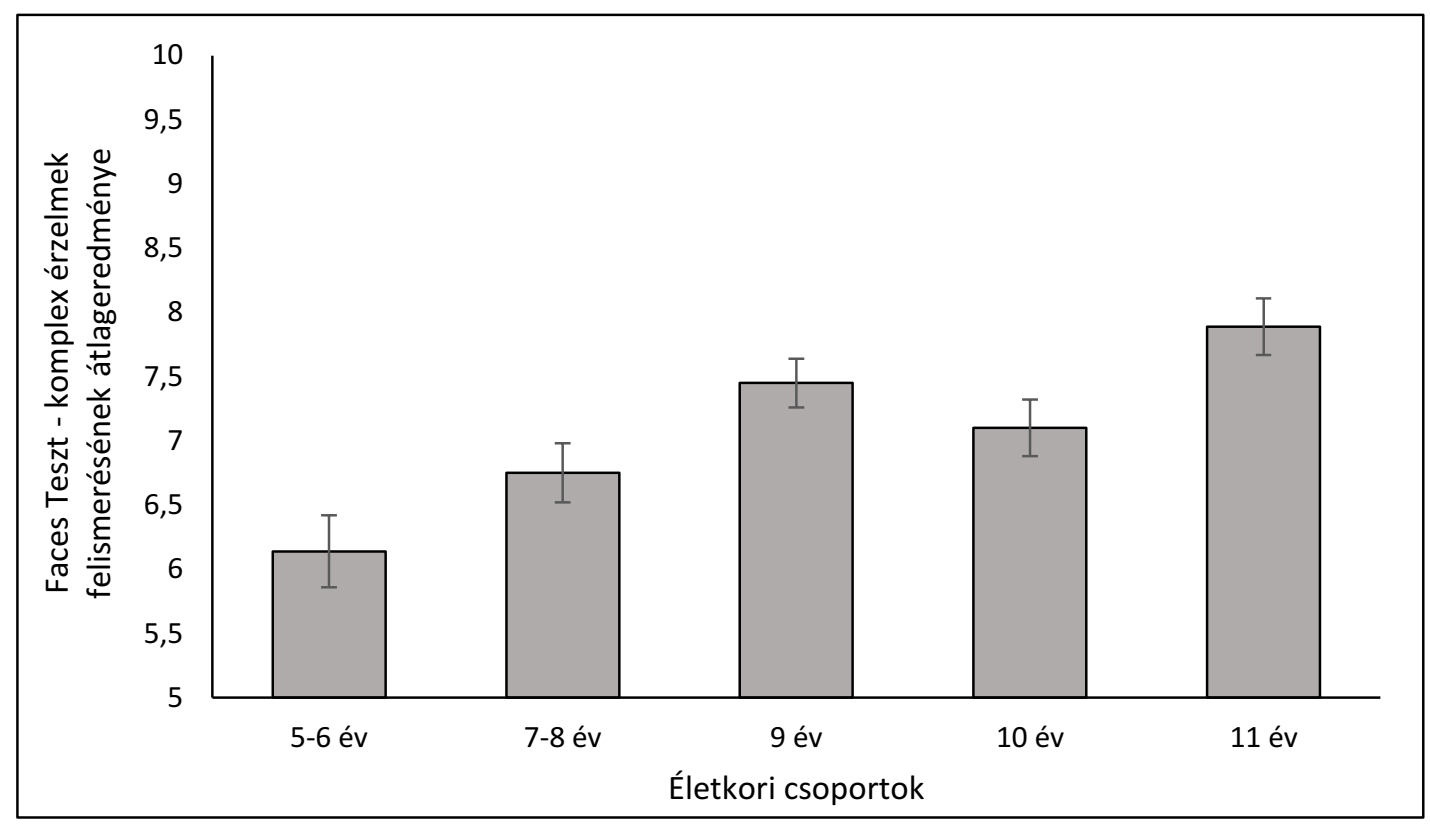

5.ábra: A Faces Teszt komplex érzelmek felismerésének átlagértékei az egyes életkori csoportokban $(\mathrm{F}(4 ; 167)=7,545, \mathrm{p}=0,000)$

A Faces Teszt összpontszámának, vagyis az alap és a komplex érzelmek felismerésének összességében szintén szignifikáns csoportfőhatást mutatnak a varianciaanalízis eredményei $(\mathrm{F}(4 ; 167)=5,059, \mathrm{p}=0,001)$. A 11 éves korcsoport eredménye szignifikánsan a legmagasabb a többi életkori csoportéhoz képest, az eredményeket a 6 . ábrán szemléltetjük. 


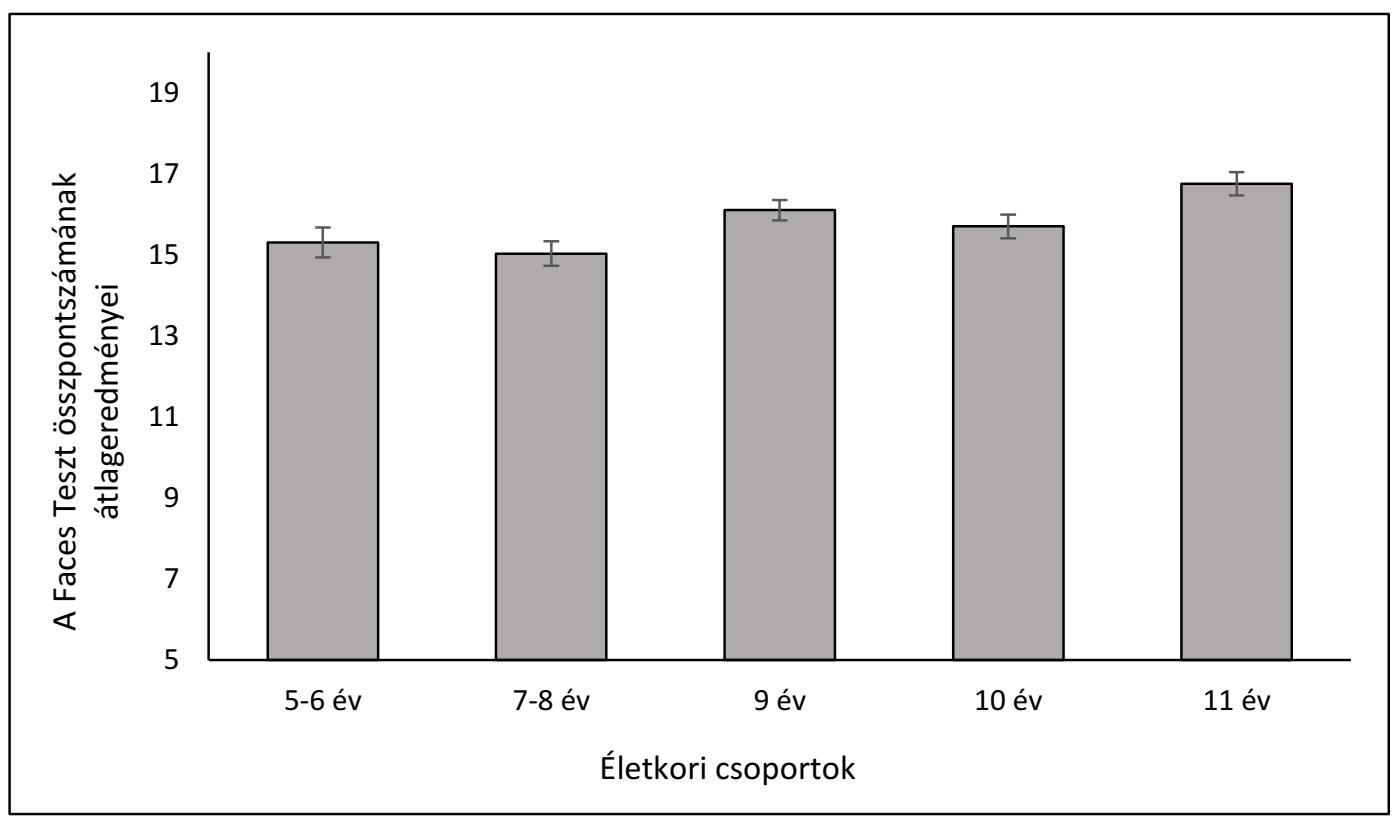

6. ábra: A Faces Teszt összpontszámának átlagértékei az egyes életkori csoportokban

$$
(\mathrm{F}(4 ; 167)=5,059, \mathrm{p}=0,001)
$$

Mindezek alapján az alapérzelmek tulajdonítása tekintetében kapott szignifikáns életkori hatás kapcsán nem vonhatunk le érvényes következtetéseket az életkori különbségekre nézve. Ennek oka, hogy plafonhatás mutatható ki a gyerekek teljesítményében, mivel még a legfiatalabb életkori csoport is $80 \%$ fölött teljesített az alapérzelmek felismerésében. Vagyis feltehető, hogy amint azt a szakirodalmi adatok is alátámasztják (1. Westby és Robinson, 2014), az alapérzelmek képről történő tulajdonítása már korábbi életkorban kialakul. Ugyanakkor a komplex érzelmek tulajdonítása tekintetében kimutatható életkori különbségek jobban értelmezhetők, hiszen nem mutatkozik plafonhatás. Megállapítható tehát, hogy a 11 éves gyerekek teljesítménye a legmagasabb, míg az 5-6 éves gyerekek teljesítménye a legalacsonyabb a mintánkban, vagyis a teljesítménynövekedés az életkorral párhuzamban halad a vizsgált mintában. 


\subsubsection{Nem szerinti különbségek a tudatelméleti müködés tekintetében az 5-11 éves gyermekek körében}

Feltételeztük, hogy mind a Faux Pas Felismerése Teszten, mind a Faces Teszten a lányok jelentősen magasabb színvonalon teljesítenek a fiúkhoz képest. Az eredmények sem a Faux Pas Felismerése Teszten $(\mathrm{F}(1 ; 162)=0,257, \mathrm{p}=0,613)$, sem a Faces Teszt egyik mutatójában sem jeleznek nemi különbségeket (Faces alapérzelmek: $F(1 ; 162)=1,089, p=0,298$, Faces komplex érzelmek: $\mathrm{F}(1 ; 162)=0,092, \mathrm{p}=0,762$; Faces összpontszám: $\mathrm{F}(1 ; 162)=0,678$, $\mathrm{p}=0,412)$. Az életkori csoport $\mathrm{X}$ nem interakció sem jelzett szignifikáns különbségeket egyik tudatelméleti teljesítményt mérő teszten sem. Jelen vizsgálatunkban tehát nem mutatható ki jelentős nemi különbség az egyes tudatelméleti teszteken mért teljesítmények között.

\subsubsection{A tudatelméleti tesztek közötti kapcsolatok az 5-11 éves korú mintában}

A tudatelméleti tesztek közötti kapcsolatok vizsgálata elsősorban amiatt érdekes kérdés, hogy mennyiben függnek össze egymással a teszteken elért teljesítmények, azaz milyen mértékben mérnek egymástól független területeket a Faux Pas Felismerése Teszt és a Faces Teszt. A tesztek közötti kapcsolatokat parciális korrelációval ellenőriztük. A parciális korrelációs együttható alkalmazására amiatt került sor, mert a fenti elemzésekből kitűnt, hogy szignifikáns életkori különbségek mutathatók ki az egyes tudatelméleti tesztek eredményeiben, így a tesztek közötti érvényes összefüggéseket az életkor kontrollálásával szükséges ellenőrizni.

Az elemzések alapján szignifikáns pozitív korreláció mutatható ki a Faux Pas Felismerése Teszten elért összteljesítmény és a Faces Teszt összpontszáma $(\mathrm{r}=0,212)$, valamint a Faces Teszt alapérzelmek felismerése $(r=0,187)$, továbbá a Faces Teszt komplex érzelmeinek felismerése között $(\mathrm{r}=0,14$, minden $\mathrm{p}<0,05)$. Érdekes továbbá, hogy az elszólás detektálása és a Faces Teszt összpontszáma $(\mathrm{r}=0,276)$, valamint a Faces Teszt komplex érzelmeinek felismerése között $(\mathrm{r}=0,253$, minden $\mathrm{p}<0,05)$ között is szignifikáns, pozitív korreláció mutatható ki. Továbbá a faux pas történetek megértésére vonatkozó kérdés és a 
Faces Teszt összpontszáma $(\mathrm{r}=0,3)$, valamint a Faces Teszt komplex érzelmeinek felismerése között $(r=0,24$, minden $\mathrm{p}<0,05)$ is szignifikáns, pozitív korreláció van. Ugyanakkor a hamis vélekedésre vonatkozó kérdés és a Faces Teszt egyik mutatója között sincs szignifikáns kapcsolat.

Az elszólás észrevétele és az affektív tudatelmélet mindegyik eleme közötti pozitív kapcsolat alapján feltételezhetjük, hogy aki képes érzékelni egy társas helyzetben elkövetett sértést, képes lehet annak a negatív érzelmi következményeit is azonosítani a vizsgált, 5-11 éves korú gyermekek körében. A történetek megértése és a komplex érzelmek felismerése közötti kapcsolat arra utalhat, hogy a komplex érzelmek feldolgozásához is szükséges bizonyos megértési képesség, vagyis annak dekódolása, hogy az adott komplex érzelmet kifejező szó valójában milyen érzelmet takarhat. Ugyanakkor az elszólások mögötti hamis vélekedések megértése és az affektív tudatelméleti komponens nem mutat kapcsolatot, vagyis feltehetően a hamis vélekedések megértése független a tudatelmélet affektív komponensétől, feltehetően a faux pas-k megértésének kognitív komponensét takarja. A korrelációs együtthatókat a 9. táblázatban szemléltetjük.

9. táblázat: A Faux Pas Felismerése Teszt és a Faces Teszt közötti korrelációs együtthatók az 5-11 éves életkorú mintában

\begin{tabular}{l|c|c|c}
\hline $\begin{array}{c}\text { Tudatelméleti } \\
\text { tesztek }\end{array}$ & $\begin{array}{c}\text { Faces Teszt } \\
\text { összpontszám }\end{array}$ & $\begin{array}{c}\text { Faces Teszt } \\
\text { alapérzelmek }\end{array}$ & $\begin{array}{c}\text { Faces Teszt } \\
\text { komplex } \\
\text { érzelmek }\end{array}$ \\
\hline $\begin{array}{l}\text { Faux Pas Teszt } \\
\text { összpontszám }\end{array}$ & $\mathbf{0 , 2 1 *}$ & $\mathbf{0 , 1 9 *}$ & $\mathbf{0 , 1 4 *}$ \\
\hline $\begin{array}{l}\text { Faux Pas Teszt- } \\
\text { elszólás detektálása }\end{array}$ & n.s. & $\mathbf{0 , 2 5 *}$ & $\mathbf{0 , 2 8 *}$ \\
\hline $\begin{array}{l}\text { Faux Pas Teszt } \\
\text { megértés }\end{array}$ & n.s. & $\mathbf{0 , 3 *}$ & $\mathbf{0 , 2 4 *}$ \\
\hline $\begin{array}{l}\text { Faux Pas Teszt- } \\
\text { hamis vélekedés }\end{array}$ & n.s. & n.s. & n.s. \\
\hline
\end{tabular}

Megjegyzés: n.s.=nem szignifikáns, ${ }^{*}$ : p<0,05; félkövérrel jelölve a szignifikáns korrelációk 
A korrelációs együtthatók ugyan gyengék, illetve mérsékeltek, de a szignifikáns korrelációs együtthatók arra utalnak, hogy a két, általunk alkalmazott eljárás nem egymástól független domaineket mér a tudatelméleten belül. Míg a Faces Teszt esetében azt mondhatjuk, hogy a tudatelmélet affektív komponensét méri, a faux pas kapcsán megállapítható, hogy definíció szerint is komplex tudatelméleti képességet mér, vagyis az elszólások teljes körü megértéséhez szükséges a kognitív és az affektív tudatelméleti komponens mozgósítása is (Stone és mtsai, 2003; Harari és mtsai, 2010; Poletti és mtsai, 2011). Ugyanakkor a faux pas megértésének kognitív komponense (a hamis vélekedés megértése) nem mutat kapcsolatot az affektív tudatelméleti mérőeszközzel. Mivel azonban a Faux Pas Felismerése Teszt gyermek változatában a feltehető kérdések között nem szerepel affektív mentálisállapot-tulajdonításra vonatkozó kérdés, csak a felnőtt változatban, így a faux pas-k megértésének affektív komponense és a Faces Teszt közötti kapcsolatokat a felnőtt tesztváltozattal mért almintán tudjuk vizsgálni.

\subsubsection{A tudatelméleti képesség életkori különbségei az 11-75 éves korú mintában}

Az adatok elemzéséhez a tesztek pontozási rendszerét, illetve statisztikai eljárásokat alkalmaztunk. Az életkori csoportok teljesítményének összehasonlítását varianciaanalízis módszerével végeztük, a tudatelméleti tesztek közötti kapcsolatokat pedig parciális korrelációs együtthatóval ellenőriztük.

\subsubsection{A Faux Pas Felismerése Teszt felnőtt változatának életkori különbségei}

A Faux Pas Felismerése Teszt felnőtt változatának eredeti pontozási rendszerét a 9.1.3.1. és 9.1.3.2. fejezetben ismertettük, eszerint minden egyes faux pas-t tartalmazó történetre összesen 6 pontot kaphat a vizsgálati személy, vagyis az elszólást tartalmazó történetekre összesen 60 pontot, míg az elszólást nem tartalmazó történetekre, azaz a kontrolltörténetekre összesen 20 pontot, történetenként 2 pontot. A faux pas-t tartalmazó és a kontrolltörténeteket az értékelés során és az adatelemzés folyamatában is külön kezeljük. Amennyiben a faux pas történetekben jelentkezik különbség például két csoport között, de a kontrolltörténetekben nem, abban az esetben specifikus tudatelméleti müködésben keresendő különbségekröl beszélhetünk (Stone és mtsai, 1998). Eszerint a pontozási rendszer szerint az 
általunk kialakított 6 életkori csoportban az elszólások felismerésének életkori különbségeit variancaanalízissel ellenőriztük. A statisztikai eljárás alapján megállapítható, hogy a 6 életkori csoport között szignifikáns csoportföhatás mutatkozik $(\mathrm{F}(5 ; 121)=8,702, \mathrm{p}=0,000)$. Az utóelemzés szerint a 12 évesek teljesítménye szignifikánsan magasabb színvonalú a 11 évesekéhez képest ( $\mathrm{p}=0,036)$, a 12 és a 13-17 éves korcsoport között nincs szignifikáns eltérés, majd a 13-17 éves korcsoport és a 18-29 évesek teljesítménye között tendencia jellegü az emelkedés ( $\mathrm{p}=0,089)$, a 18-29 és a 30-59 évesek teljesítménye statisztikailag nem különül el, azonban a 60-75 évesek szignifikánsan alacsonyabb színvonalon teljesítenek minden fiatalabb korosztályhoz képest jelen vizsgálatban. A faux pas-t tartalmazó történetekre vonatkozó eredményeket a 7. ábrán mutatjuk be. A kontrolltörténetek elemzésénél azonban nem jelentkezik szignifikáns csoportföhatás $(\mathrm{F}(5 ; 121)=1,085, \mathrm{p}=0,372)$, vagyis az életkorból eredő különbségek valóban a tudatelméleti müködésben jelentkező eltérésnek tulajdoníthatók a vizsgált mintában.

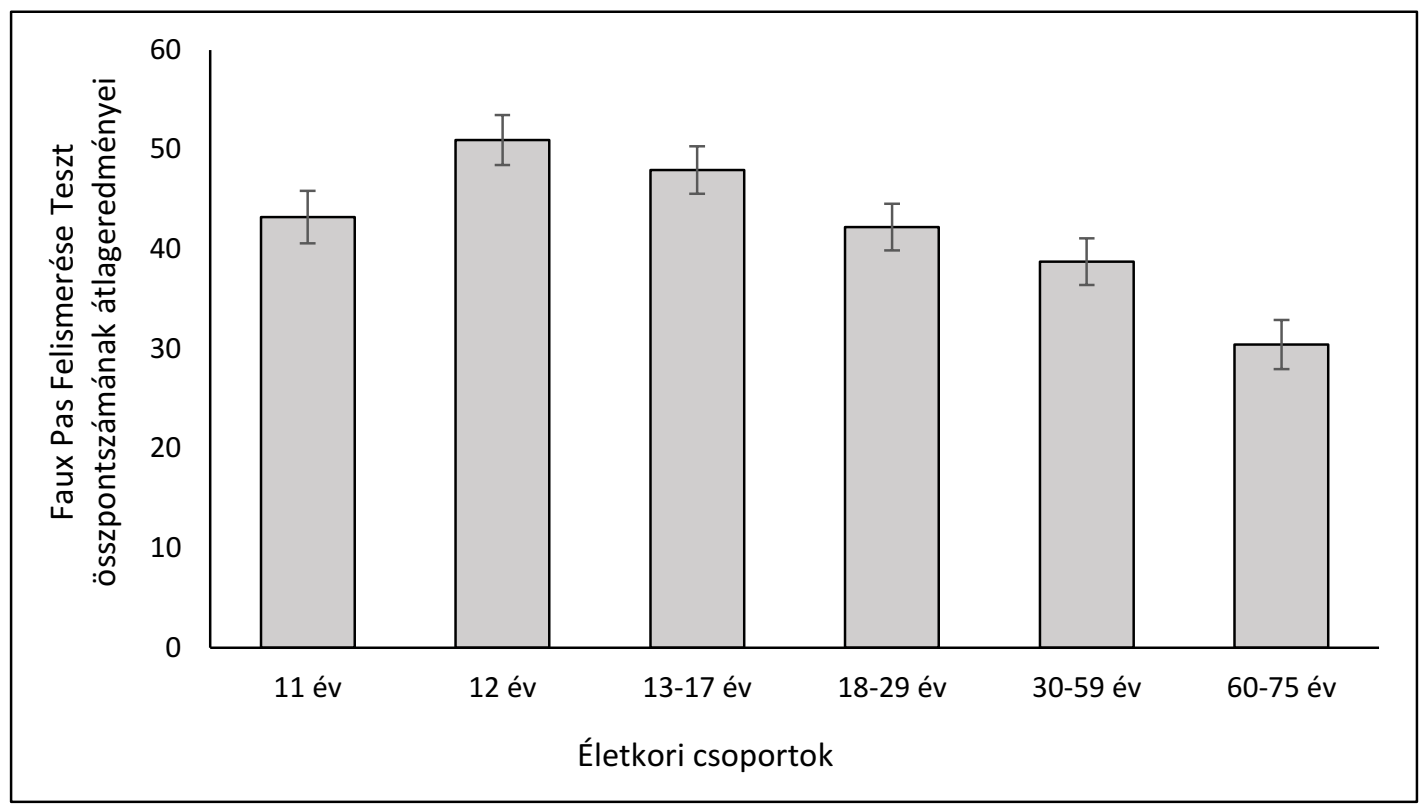

7. ábra: A Faux Pas Felismerése Teszt felnőtt változatán nyújtott teljesítmény életkori különbségei 11 éves kortól 75 éves korig $(F(5 ; 121)=8,702, p=0,000)$ 
Az eredeti pontozási rendszer mellett azonban más pontozási metódusokat is alkalmaztunk a felnőtt tesztváltozat korábbi alkalmazása során (Gál, Egyed, Pászthy és Németh, 2011; Gál, Katona, Janacsek és Németh, 2014). Jelen vizsgálatunkban faux pas a kognitív komponensére, azaz a hamis vélekedés megértésére vonatkozó kérdések, továbbá az affektív komponensére, azaz az elszólást követő negatív érzelmi következmények felismerésére vonatkozó kérdések összpontszámának átlagait és összehasonlítottuk az egyes életkori csoportokban. A varianciaanalízis eredményei szerint az elszólások mögötti hamis vélekedés megértésében szignifikáns életkori csoportfőhatás mutatkozik $(\mathrm{F}(5 ; 121)=6,66$, $\mathrm{p}<0,001)$. Az utóelemzések szerint a 12 évesek szignifikánsan magasabb színvonalon teljesítenek a 11 évesekhez képest $(\mathrm{p}=0,014)$, majd a 12 évesek és a 13-17 évesek teljesítménye közötti különbség nem szignifikáns. A 13-17 évesekhez képest a 18-29 évesek teljesítménye már tendenciaszinten alacsonyabb $(\mathrm{p}=0,089)$. Továbbá a 18-29 és a 30-59 évesek teljesítménye nem különbözik szignifikánsan, azonban a 60-75 évesek teljesítménye már szignifikánsan alacsonyabb színvonalú minden fiatalabb korcsoporthoz képest. A faux pas összpontszámhoz hasonlóan az a tendencia érvényesül, hogy az elszólások mögötti hamis vélekedés megértésében az időskorra romlik a teljesítmény a vizsgált mintában. Az eredményeket a 8 . ábrán szemléltetjük.

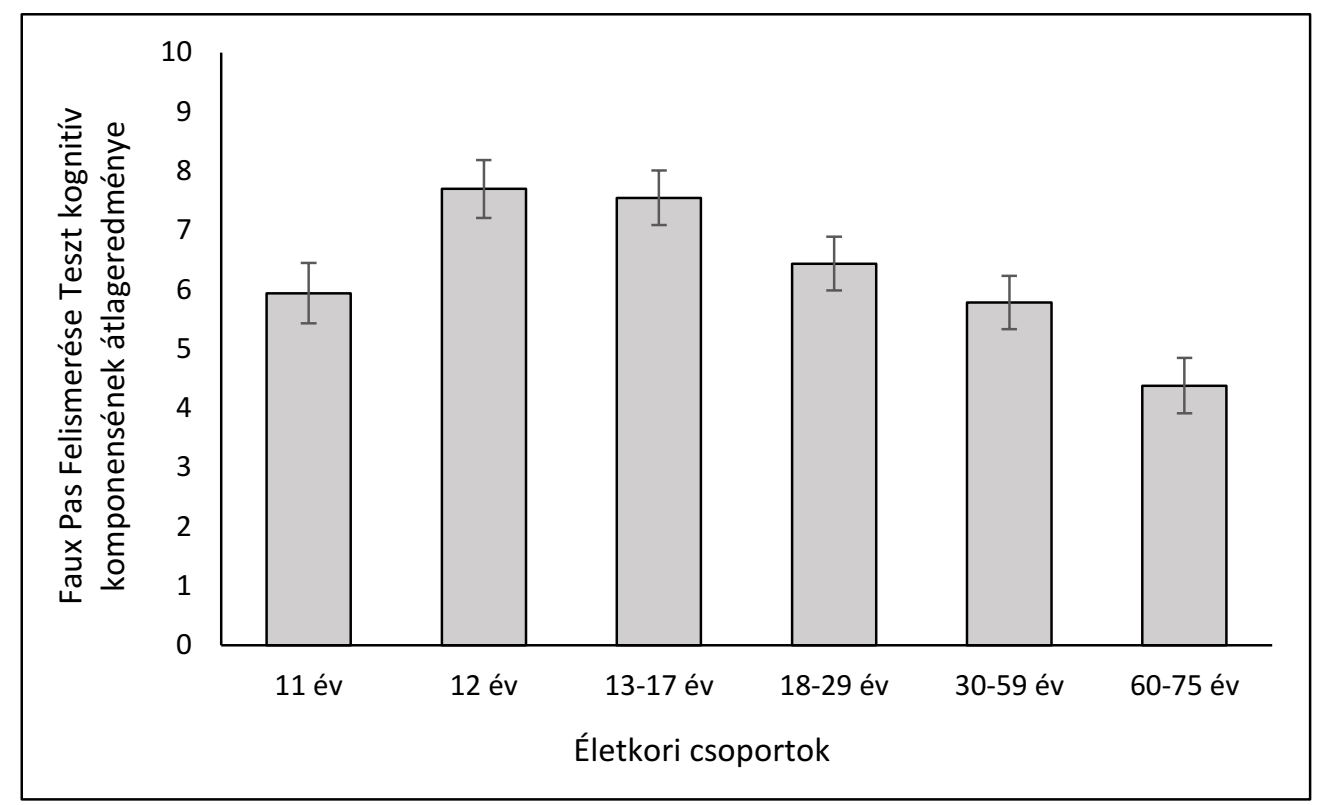

8. ábra: A Faux Pas Felismerése Teszt hamis vélekedés megértésére vonatkozó kérdésén nyújtott teljesítmény életkori különbségei 11 éves kortól 75 éves korig $(F(5 ; 121)=6,66$, $\mathrm{p}<0,001)$ 
Az elszólást követő negatív érzelmi következmények felismerésének tekintetében a varianciaanalízis eredményei szerint szignifikáns életkori csoportfőhatás mutatkozik $(F(5 ; 121)=7,147, p<0,001)$. Az utóelemzések szerint a 11 évesek és 12 évesek teljesítménye nem különbözik szignifikánsan egymástól, hasonlóan a 12 és a 13-17 évesek, illetve a 13-17 és a 18-29 évesek, továbbá a 18-29 és 30-59 évesek között sem mutatkozik teljesítménykülönbség, a 60-75 évesek pedig már alacsonyabb színvonalon teljesítenek az affektív mentális állapottulajdonítás tekintetében. Azaz a vizsgált idős korosztály teljesítménye a legalacsonyabb a mintán belül az elszólást követő negatív érzelmi következmények, vagyis az affektív mentális állapottulajdonítás tekintetében. Az életkori csoportok közötti szignifikáns eltéréseket a 10. táblázatban ismertetjük, illetve a 9. ábrán szemléltetjük.

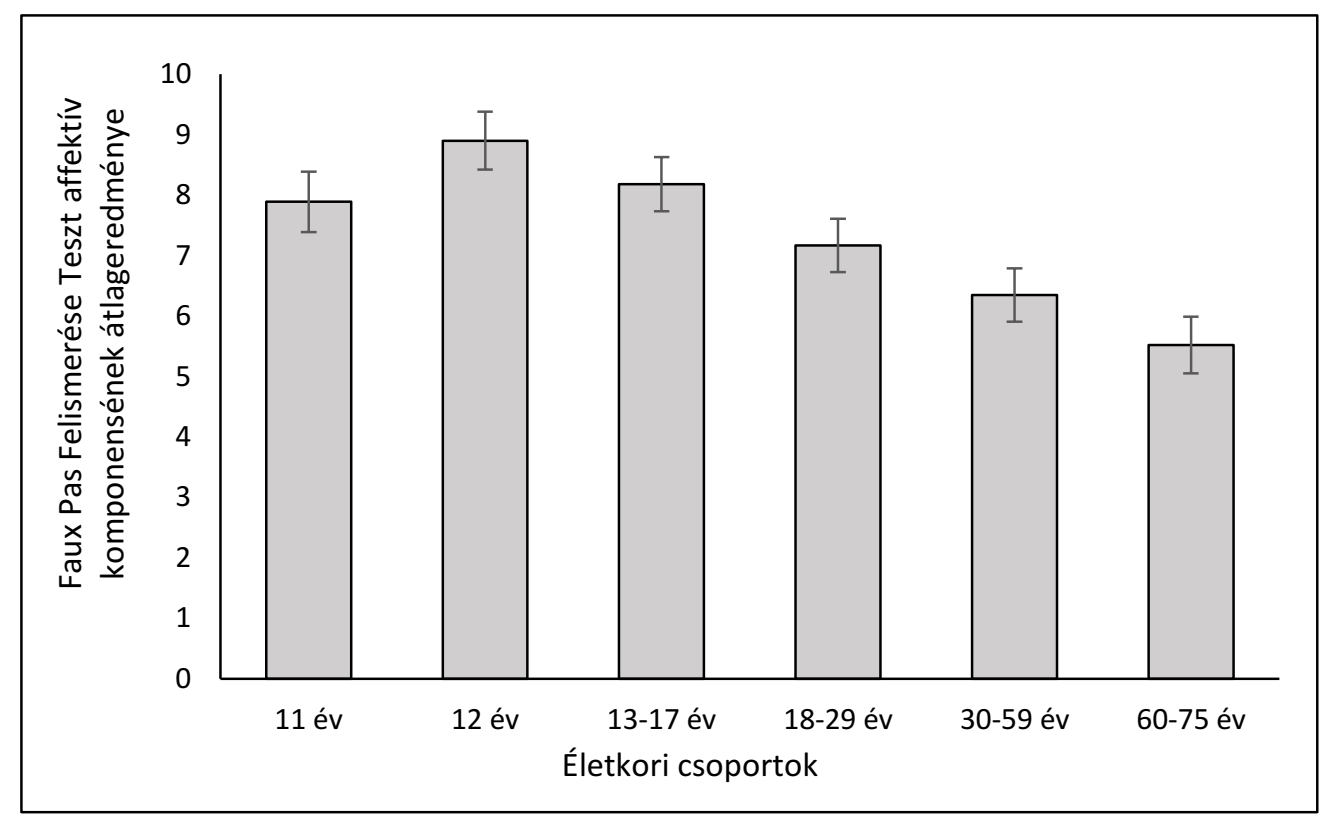

9. ábra: A Faux Pas Felismerése Teszt negatív érzelmi következmények megértésére vonatkozó kérdésén nyújtott teljesítmény életkori különbségei 11 éves kortól 75 éves korig $(F(5 ; 121)=7,147, \mathrm{p}<0,001)$ 
Összességében jelen vizsgálat eredményei azt mutatják, hogy a faux pas felismerése és megértése kapcsán 11 és 12 éves kor között teljesítményemelkedés, majd a 13-17 éves korosztálytól enyhe teljesítménycsökkenés jelentkezik, ami aztán az idős, 60-75 éves korosztályban a legalacsonyabb, minden fiatalabb életkori csoporthoz képest. Ez a tendencia a faux pas kognitív és affektív komponense kapcsán is megfigyelhető a mintában.

\subsubsection{A Faces Teszt életkori különbségei az, 11-75 éves korosztályban}

Feltételezéseink szerint míg a Faces Teszt alapérzelmek felismerése tekintetében nem, addig a komplex érzelmek tekintetében már észlelhetünk életkori különbségeket 11-75 éves kor között. Ennek a feltételezésnek a hátterében az áll, hogy az affektív tudatelméleti müködés még a serdülökor és a fiatal felnőttkor között is fejlődést mutat (Sebastian és mtsai, 2012). Továbbá idősek, középkorúak és fiatal felnőttek összehasonlításában az affektív tudatelméleti teszten az alapérzelmek kapcsán nem találtak eltérést az életkori csoportok között, azonban a komplex érzelmek tulajdonításában a középkorúak, és az idősek is rosszabbul teljesítettek a fiatal csoporthoz képest (Duval és mtsai, 2010).

$\mathrm{Az}$ eredményeink arra utalnak, hogy a Faces Tesztben a 10 alapérzelmeket megjelenítő fotón az érzelmek tulajdonítása során szignifikáns életkori csoportfőhatás mutatkozik $(\mathrm{F}(5 ; 121)=2,345, \mathrm{p}=0,045) . \quad \mathrm{Az}$ alapérzelmek tulajdonítása tekintetében az átlagértékek 8,7 és 9,1 pontszámok között mozogtak, feltehetően plafonhatás jelenik meg a teszt ezen részében, vagyis emiatt a csoportföhatásra vonatkozó eredményeink korlátozottan értelmezhetök, és nem feltétlenül vonhatók le érvényes következtetések az életkori különbségekre vonatkozóan. A Faces Teszt komplex érzelmeinek tulajdonítását tekintve nem találunk szignifikáns életkori csoportfőhatást $(\mathrm{F}(5 ; 121)=1,728, \mathrm{p}=0,133)$. Az átlagértékek a komplex érzelmek tekintetében 8 és 9 pontszámok között mozogtak, feltehetően plafonhatás jelenik meg a teszt ezen részében is. A Faces Teszt összpontszámának, vagyis az alap és a komplex érzelmek felismerésének összességében szintén nem mutatnak szignifikáns csoportfőhatást a varianciaanalízis eredményei $(\mathrm{F}(5 ; 121)=1,173, \mathrm{p}=0,327)$. Hasonlóan plafonhatás feltételezhető az összpontszámok tekintetében, azaz a maximális 20 pontból a legalacsonyabb elért átlagpontszám is 17,1. A Faces Teszt eredményei kapcsán emiatt azt feltételezhetjük, hogy az általunk vizsgált mintában az életkori különbségek nem mutathatók ki, ez feltehetően amiatt lehetséges, mert mind az alap, mind a komplex érzelmek tekintetében 
magas színvonalon teljesítettek az általunk vizsgált személyek, azaz feltehetően a plafonhatás lehet oka a különbségek hiányának. Vélhetően egy érzékenyebb, jobban differenciáló mérőeszközzel az életkor különbségek már regisztrálhatók. A tudatelméleti tesztek átlageredményeit a 10. táblázatban ismertetjük.

10. táblázat: Átlageredmények a tudatelméleti teszteken az 11-75 éves korosztályban

\begin{tabular}{|c|c|c|c|c|c|c|c|}
\hline \multirow[b]{2}{*}{$\begin{array}{l}\text { ToM } \\
\text { teljesítmény }\end{array}$} & 11 év & 12 év & 13-17 év & 18-29 év & 30-59 év & 60-75 év & \multirow[b]{2}{*}{$F(p)$} \\
\hline & $\begin{array}{c}\text { Átlag } \\
\text { (szórás) }\end{array}$ & $\begin{array}{l}\text { Átlag } \\
\text { (szórás) }\end{array}$ & $\begin{array}{l}\text { Átlag } \\
\text { (szórás) }\end{array}$ & $\begin{array}{c}\text { Átlag } \\
\text { (szórás) }\end{array}$ & $\begin{array}{c}\text { Átlag } \\
\text { (szórás) }\end{array}$ & $\begin{array}{l}\text { Átlag } \\
\text { (szórás) }\end{array}$ & \\
\hline $\begin{array}{l}\text { Faux Pas } \\
\text { Felismerése } \\
\text { Teszt } \\
\text { összpontszám }\end{array}$ & $\begin{array}{l}43,22 \\
(2,64)\end{array}$ & $\begin{array}{l}50,95 \\
(2,51)\end{array}$ & $\begin{array}{l}47,96 \\
(2,39)\end{array}$ & $\begin{array}{l}42,22 \\
(2,34)\end{array}$ & $\begin{array}{l}38,74 \\
(2,34)\end{array}$ & $\begin{array}{l}30,43 \\
(2,45)\end{array}$ & $\begin{array}{c}\mathrm{F}(5 ; 121)=8,7 \\
\mathrm{p}<0,001\end{array}$ \\
\hline $\begin{array}{l}\text { Faux Pas } \\
\text { Felismerése } \\
\text { Teszt - kontroll } \\
\text { történetek }\end{array}$ & $\begin{array}{c}18 \\
(0,55)\end{array}$ & $\begin{array}{c}19,2 \\
(0,52)\end{array}$ & $\begin{array}{l}17,77 \\
(0,49)\end{array}$ & $\begin{array}{l}18,61 \\
(0,48)\end{array}$ & $\begin{array}{l}18,35 \\
(0,48)\end{array}$ & $\begin{array}{l}18,86 \\
(0,51)\end{array}$ & $\begin{array}{c}\mathrm{F}(5 ; 121)=1,085 \\
\mathrm{p}=0,372\end{array}$ \\
\hline $\begin{array}{l}\text { Faux Pas } \\
\text { Felismerése } \\
\text { Teszt }- \text { hamis } \\
\text { vélekedés }\end{array}$ & $\begin{array}{c}5,94 \\
(0,51)\end{array}$ & $\begin{array}{c}7,7 \\
(0,49)\end{array}$ & $\begin{array}{l}7,55 \\
(0,46)\end{array}$ & $\begin{array}{c}6,44 \\
(0,45)\end{array}$ & $\begin{array}{l}5,78 \\
(0,45)\end{array}$ & $\begin{array}{l}4,38 \\
(0,47)\end{array}$ & $\begin{array}{c}\mathrm{F}(5 ; 121)=6,759 \\
\mathrm{p}<0,001\end{array}$ \\
\hline $\begin{array}{l}\text { Faux Pas } \\
\text { Felismerése } \\
\text { Teszt - affektív } \\
\text { mentálisállapot- } \\
\text { tulajdonítás }\end{array}$ & $\begin{array}{l}7,89 \\
(0,5)\end{array}$ & $\begin{array}{c}8,9 \\
(0,48)\end{array}$ & $\begin{array}{l}8,18 \\
(0,45)\end{array}$ & $\begin{array}{c}7,17 \\
(0,44)\end{array}$ & $\begin{array}{c}6,35 \\
(0,44)\end{array}$ & $\begin{array}{c}5,52 \\
(0,47)\end{array}$ & $\begin{array}{c}\mathrm{F}(5 ; 121)=7,147 \\
\mathrm{p}<0,001\end{array}$ \\
\hline $\begin{array}{l}\text { Faces Teszt - } \\
\text { összpontszám }\end{array}$ & $\begin{array}{c}17,1 \\
(0,44) \\
\end{array}$ & $\begin{array}{c}17,7 \\
(0,48) \\
\end{array}$ & $\begin{array}{l}17,7 \\
(0,4)\end{array}$ & $\begin{array}{l}18,22 \\
(0,39) \\
\end{array}$ & $\begin{array}{l}17,22 \\
(0,39) \\
\end{array}$ & $\begin{array}{l}17,14 \\
(0,41) \\
\end{array}$ & $\begin{array}{c}\mathrm{F}(5 ; 121)=1,173 \\
\mathrm{p}=0,327\end{array}$ \\
\hline $\begin{array}{l}\text { Faces Teszt - } \\
\text { alapérzelmek }\end{array}$ & $\begin{array}{c}9,06 \\
(0,23) \\
\end{array}$ & $\begin{array}{c}9,4 \\
(0,22) \\
\end{array}$ & $\begin{array}{c}9,59 \\
(0,21) \\
\end{array}$ & $\begin{array}{l}9,17 \\
(0,2) \\
\end{array}$ & $\begin{array}{c}8,7 \\
(0,2) \\
\end{array}$ & $\begin{array}{c}8,95 \\
(0,21) \\
\end{array}$ & $\begin{array}{c}\mathrm{F}(5 ; 121)=2,345 \\
\mathrm{p}=0,045\end{array}$ \\
\hline $\begin{array}{l}\text { Faces Teszt - } \\
\text { komplex } \\
\text { érzelmek }\end{array}$ & $\begin{array}{c}8,06 \\
(0,31)\end{array}$ & $\begin{array}{c}8,3 \\
(0,3)\end{array}$ & $\begin{array}{c}8,1 \\
(0,28)\end{array}$ & $\begin{array}{l}9,04 \\
(0,28)\end{array}$ & $\begin{array}{c}8,52 \\
(0,28)\end{array}$ & $\begin{array}{c}8,19 \\
(0,29)\end{array}$ & $\begin{array}{c}\mathrm{F}(5 ; 121)=1,728 \\
\mathrm{p}=0,133\end{array}$ \\
\hline
\end{tabular}

\subsubsection{Nem szerinti különbségek a tudatelméleti müködésben az 11-75 éves korú mintában}

Feltételeztük, hogy mind a Faux Pas Felismerése Teszten, mind a Faces Teszten a nők jelentősen magasabb színvonalon teljesítenek a férfiakhoz képest. Az eredmények a Faux Pas Felismerése Teszt kontroll történeteinek összpontszáma és a Faces Teszt alapérzelmeinek felismerésén kívül minden tesztben szignfikáns nemi különbségek mutatkoznak. 
Az eredmények szerint a Faux Pas Felismerése Teszten $(F(1 ; 115)=11,626, p=0,001)$ a nök szignifikánsan magasabb színvonalon teljesítenek, csakúgy, mint a Faces Teszt komplex érzelmei $(\mathrm{F}(1 ; 115)=9,766, \mathrm{p}=0,002)$ és Faces összpontszám $(\mathrm{F}(1 ; 115)=7,224, \mathrm{p}=0,008)$ tekintetében. Az életkori csoport X nem interakció azonban egyik tudatelméleti teszten sem jelzett szignifikáns különbségeket. Jelen vizsgálatunkban tehát jelentős nemi különbség az egyes tudatelméleti teszteken mért teljesítmények között kimutatható, a nök teljesítménye magasabb színvonalú a komplex (kognitív és affektív) és az affektív tudatelmélet tekintetében.

\subsubsection{A tudatelméleti tesztek közötti kapcsolatok az 11-75 éves korú mintában}

A tudatelméleti tesztek közötti kapcsolatok vizsgálata kapcsán kutatási kérdésünk volt, hogy milyen mértékben függnek össze az egyes tudatelméleti tesztek, koncentrálva esősorban a Faux Pas Felismerése Teszt és a Faces Tesztek közötti kapcsolatra. A tesztek közötti összefüggéseket parciális korrelációval ellenőriztük, hiszen a fenti elemzésekből kitűnt, hogy szignifikáns életkori különbségek mutathatók ki az egyes tudatelméleti tesztek eredményeiben, így a tesztek közötti érvényes összefüggéseket az életkor kontrollálásával szükséges ellenőrizni. Az elemzések alapján szignifikáns pozitív korreláció mutatható ki a Faux Pas Felismerése Teszten elért összteljesítmény és a Faces Teszt összpontszáma $(r=0,2)$, valamint a Faces Teszt komplex érzelmeinek felismerése között $(r=0,214$, minden $p<0,05)$. A faux pas-k mögötti hamis vélekedésre vonatkozó kérdés és a Faces Teszt összpontszáma $(\mathrm{r}=0,184, \mathrm{p}<0,05)$ között is szignifikáns pozitív korreláció van. Továbbá az elszólást követő negatív érzelmi következmények felismerése és a Faces Teszt komplex érzelmeinek felismerése között $(\mathrm{r}=0,212)$, illetve a Faces Teszt összpontszáma között $(\mathrm{r}=0,2$, minden p <0,05) mutatkozik szignifikáns pozitív korreláció. Ugyanakkor a Faux Pas Felismerése Teszt kontroll történetei egyik tudatelméleti teszttel sem mutatnak korrelációt. A tudatelméleti feladatok és a kontrolltörténetek közötti összefüggés hiánya arra utal, hogy valóban eltérő területeket vesznek igénybe e feladatok megoldásai. Továbbá a Faux Pas Felismerése Teszt elszólásokat tartalmazó történetei, illetve a kognitív és affektív komponense a Faces Teszt alapérzelmek felismerésével nem jeleznek kapcsolatot, ugyanakkor a komplex érzelmek felismerésével szignifikáns, gyenge kapcsolatban állnak. A faux pas-k kognitív komponense, azaz az elszólások mögötti hamis vélekedések megértése is korrelál a Faces 
összpontszámmal, ennek hátterében elsősorban az állhat, hogy az összteljesítményben már szerepelnek a komplex érzelmek is, ezek vélekedésen alapuló érzelmek, azaz gondolatok, vélekedések tulajdonítása is szükséges az adott komplex érzelem felismeréséhez. A korrelációs együtthatókat a 11. táblázatban szemléltetjük.

11. táblázat: A Faux Pas Felismerése Teszt és a Faces Teszt közötti korrelációs együtthatók az 11-75 éves életkorú mintában

\begin{tabular}{l|c|c|c}
\hline Tudatelméleti tesztek & $\begin{array}{c}\text { Faces Teszt } \\
\text { összpontszám }\end{array}$ & $\begin{array}{c}\text { Faces Teszt } \\
\text { alapérzelmek }\end{array}$ & $\begin{array}{c}\text { Faces Teszt } \\
\text { komplex } \\
\text { érzelmek }\end{array}$ \\
\hline $\begin{array}{l}\text { Faux Pas Teszt } \\
\text { összpontszám }\end{array}$ & $\mathbf{0 , 2 *}$ & n.s. & $\mathbf{0 , 2 1 *}$ \\
\hline $\begin{array}{l}\text { Faux Pas Teszt }- \\
\text { kontroll történetek }\end{array}$ & n.s. & n.s. & n.s. \\
\hline $\begin{array}{l}\text { Faux Pas Teszt }- \\
\text { hamis vélekedés }\end{array}$ & $\mathbf{0 , 1 8 *}$ & n.s. & n.s. \\
\hline $\begin{array}{l}\text { Faux Pas Teszt - negatív } \\
\text { érzelmi következmények }\end{array}$ & $\mathbf{0 , 2 *}$ & n.s. & $\mathbf{0 , 2 1 *}$ \\
\hline
\end{tabular}

Megjegyzés: $n . s .=$ nem szignifikáns, ${ }^{*}: \mathrm{p}<0,05$; félkövérrel jelölve a szignifikáns korrelációs együtthatók

A tesztek között meglévő kapcsolatok azt jelzik, hogy a faux pas-k felismerése és megértésének képessége nem teljesen független az affektív tudatelméleti müködéstől, ez egybevág azzal a módszertani megfontolással, hogy a faux pas-k megértése bonyolultabb, komplexebb tudatelméleti müködést igényel, a kognitív tudatelméleti komponens mellett az affektív komponens mozgósítása is szükséges a faux pas-k megértéséhez. Érdekes eredmény tehát, hogy az 5-11 éves korú mintához képest a felnőtt tesztváltozat esetében kevesebb és alacsonyabb korreláció mutatkozott a tesztek között. Ennek oka lehet az is, hogy kevésbé igényli például a kognitív erőfeszítést, a vélekedések, szándékok tulajdonítását az affektív tudatelméleti komponenst mérő teszt megoldása. Ez felveti annak kérdését, hogy a tudatelméleti tesztek és a kognitív funkciók (pl. a munkamemória kapacitása) között milyen összefüggések mutathatók ki, ez azonban a második vizsgálatsorozatunk fő kérdése. 


\subsection{A második vizsgálatban kapott eredmények ismertetése}

A második vizsgálat során arra kerestük a választ, hogy a munkamemória-kapacitás és a tudatelméleti teljesítmény között milyen összefüggések tárhatók fel. A korábbi kutatások már végeztek vizsgálatokat óvodáskorú gyerekek (pl. Carlson és Moses, 2001; Razza és Blair, 2009) illetve felnőttek és idősek körében (pl. McKinnon és Moscovitch, 2007; Duval és mtsai, 2010) a kognitív funkciók és a tudatelmélet közötti kapcsolatok alakulásáról. Ugyanakkor kevés kutatás számol be az iskoláskorú gyerekek tudatelméleti képességének és munkamemória kapacitásának összefüggéseiről, továbbá konkrétan a komplex tudatelméletet mérő Faux Pas Felismerése Teszten, a Faces Teszten elért teljesítmény és a munkamemória kapacitás kapcsolatáról.

A korábbi kutatások alapján azt várjuk, hogy mind a gyermek, mind a felnőtt tesztváltozattal mért mintánkban kapcsolat mutatható ki a tudatelméleti teszteken elért teljesítmény és a munkamemória kapacitás között. A komplex tudatelméletet egyrészt a Faux Pas Felismerése Teszttel mértük, a 7-11 éves korcsoportokban a gyermek változatával (Baron-Cohen és mtsai, 1999), a 11-75 éves korosztályban pedig a felnőtt változatával (Stone és mtsai, 1998; Gál, Egyed, Pászthy és Németh, 2011; Gál, Katona, Janacsek és Németh, 2014). Az affektív tudatelméleti működés mérését a Faces Teszttel végeztük (Baron-Cohen, Weelwright és Jollife, 1997). A munkamemória kapacitás mérésére a Számterjedelem Tesztet (Racsmány, és mtsai, 2005), a Fordított Számterjedelem Tesztet, és a Hallási Mondatterjedelem Tesztet (Janacsek és mtsai, 2009). A vizsgálatunkba bevont 240 személyt két korosztályi csoportra bontottuk, ezt elsősoban módszertani okok indokolták, mivel a Faux Pas Felismerése Teszt gyermek változata 7-11 éves korban méri megfelelöen a tudatelmélet müködést (Baron-Cohen és mtsai, 1999), míg a serdülő és felnőttkorú mintában a felnőtt változatot alkalmaztuk. Eredményeinket a továbbiakban a két korcsoporti almintának megfelelően ismertetjük. 


\subsubsection{A tudatelmélet és a munkamemória kapacitás közötti összefüggések vizsgálata a 7-11 éves életkorú mintán}

Az adatok elemzéséhez a tesztek pontozási rendszerét, illetve statisztikai eljárásokat alkalmaztunk. A munkamemória és a tudatelméleti müködés összefüggéseinek vizsgálatát parciális korrelációval ellenőriztük az életkor kontrollálásával. Az alábbi, 12. táblázatban táblázatban ismertetjük a tudatelméleti teszteken és a munkamemória teszteken mért átlageredményeket a 7-11 éves életkorú mintában.

12. táblázat: Átlageredmények a tudatelméleti és munkamemória teszteken a 7-11 éves életkorú mintában

\begin{tabular}{l|c}
\hline & Átlag (szórás) \\
Teszteredmények & \\
\hline \hline Faux Pas Teszt összpontszám & $3,44(0,22)$ \\
\hline Faux Pas Teszt - elszólás detektálása & $6,94(0,22)$ \\
\hline Faux Pas Teszt - megértés & $7,37(0,21)$ \\
\hline Faux Pas Teszt - hamis vélekedés & $6,54(0,23)$ \\
\hline Faces Teszt - alapérzelmek & $8,64(0,1)$ \\
\hline Faces Teszt - bonyolult érzelmek & $7,33(0,13)$ \\
\hline Faces Teszt - összpontszám & $15,96(0,19)$ \\
\hline Számterjedelem Teszt & $5,13(0,1)$ \\
\hline Fordított Számterjedelem Teszt & $3,28(0,1)$ \\
\hline Hallási Mondatterjedelem Teszt & $2,57(0,08)$ \\
\hline
\end{tabular}

\subsubsection{A Faux Pas Felismerése Teszten elért tudatelméleti teljesítmény és a munkamemória kapacitás közötti összefüggések a 7-11 éves életkorú mintában}

A Faux Pas Felismerése Teszt pontozási rendszere alapján a faux pas történetekre vonatkozó összpontszám és az egyes munkamemóriát mérő teszteken elért teljesítményt vetettük össze parciális korrelációs elemzés segítségével, ahol az életkor változóját kontrolláltuk. A parciális korrelációs elemzés eredményei alapján a Faux Pas Felismerése Teszt összpontszáma a Számterjedelem Teszttel (SzTer) mért verbális munkamemória kapacitással nem, míg a munkamemória mérésére szolgáló Fordított Számterjedelem (FSzTer; 
$\mathrm{r}=0,19)$ és Hallási Mondatterjedelem Teszt (HMT; $\mathrm{r}=0,35)$ eredményeivel szignifikáns pozitív korrelációt mutat. A Faux Pas Felismerése Teszt egyes összetevői esetében megállapítható, hogy az elszólás detektálására vonatkozó kérdés eredménye a Számterjedelem és a Hallási Mondatterjedelem teszttel szignifikáns pozitív kapcsolatban áll (SzTer: r=0,23, HMT: r=0,2). Az elszólás mögötti hamis vélekedés megértésére vonatkozó kérdésre adott válaszok csak a Hallási Mondatterjedelem Teszttel állnak szignifikáns pozitív kapcsolatban $(\mathrm{r}=0,28)$. A legmagasabb korrelációs együtthatók a történetek megértésére vonatkozó kérdésekkel mutatkoznak, ahol mindhárom emlékezeti teszttel szignifikáns pozitív összefüggéseket találhatunk (SzTer: r=0,45, FSzTer: r=0,27, HMT: r=0,52). A korrelációs együtthatókat a 13. táblázatban tüntetjük fel.

13. táblázat: A Faux Pas Felismerése Teszt és a munkamemória tesztek közötti parciális korrelációs együtthatók az 7 -11 éves életkorú mintában

\begin{tabular}{l|c|c|c}
\hline \multicolumn{1}{c|}{ Munkamemória tesztek } & $\begin{array}{c}\text { Számterjedelem } \\
\text { Teszt }\end{array}$ & $\begin{array}{c}\text { Forditott } \\
\text { Számterjedelem } \\
\text { Teszt }\end{array}$ & $\begin{array}{c}\text { Hallási } \\
\text { Mondatterjedelem Teszt }\end{array}$ \\
\hline $\begin{array}{l}\text { Faux Pas Teszt } \\
\text { összpontszám }\end{array}$ & n.s. & $\mathbf{0 , 1 9 *}$ & $\mathbf{0 , 3 5 *}$ \\
\hline $\begin{array}{l}\text { Faux Pas Teszt-elszólás } \\
\text { detektálása }\end{array}$ & $\mathbf{0 , 2 3 *}$ & n.s. & $\mathbf{0 , 2 *}$ \\
\hline Faux Pas Teszt-megértés & $\mathbf{0 , 4 5 *}$ & $\mathbf{0 , 2 7 *}$ & $\mathbf{0 , 5 2 *}$ \\
\hline $\begin{array}{l}\text { Faux Pas Teszt-hamis } \\
\text { vélekedés }\end{array}$ & n.s. & n.s. & $\mathbf{0 , 2 8 *}$ \\
\hline
\end{tabular}

Megjegyzés: $n . s .=$ nem szignifikáns, ${ }^{*}: \mathrm{p}<0,05$; félkövérrel jelölve a szignifikáns korrelációs együtthatók

A parcális korrelációs együtthatók alapján, az életkor kiszürését követően, elsősorban a komplex munkamemória kapacitása, azaz a Hallási Mondatterjedelem Teszttel mért teljesítmény áll összefüggésben a faux pas-k felismerésének képességével a jelen vizsgálati mintában. Azaz minél jobb komplex munkamemória kapacitással rendelkezik a személy, annál jobb színvonalú teljesítményt nyújt a tudatelméleti teszten és azok összetevőin. Különösen fontos, hogy a történetek megértésére vonatkozó kérdésekkel mindhárom emlékezeti teszt pozitívan korrelál, azaz az egyedi történetek megértésében, a történésekre való odafigyelésben különösen fontos a munkamemória kapacitás szerepe a vizsgált mintában. Továbbá az elszólások felismerésében a verbális munkamemória és a komplex 
munkamemória, míg a hamis vélekedés megértésében elsősorban a komplex munkamemória kapacitása mutat magasabb összefüggést a teszten elért teljesítménnyel.

\subsubsection{A Faces Teszten elért tudatelméleti teljesítmény és a munkamemória kapacitás közötti összefüggések a 7-11 éves életkorú mintában}

A FacesTeszt pontozási rendszere alapján a tesztre vonatkozó összpontszám, az alap és a komplex érzelmek felismerésére vonatkozó és az egyes munkamemóriát mérő tesztekkel mért munkamemória kapacitást vetettük össze parciális korrelációs elemzés segítségével, ahol az életkor változóját kontrolláltuk. A parciális korrelációs elemzés eredményei alapján Faces Teszt összpontszáma minden emlékezeti teszt eredményével szignifikáns pozitív korrelációt mutat (SzTer: $\mathrm{r}=0,4$; FSzTer: $\mathrm{r}=0,34$; HMT: $\mathrm{r}=0,43$, minden $\mathrm{p}<0,05$ ). A Faces Tesztben az alapérzelmek felismerése szintén minden emlékezeti teszttel szignifikáns pozitív összefüggésben áll (SzTer: $r=0,21$; FSzTer: $r=0,24$; HMT: $r=0,39$, minden $p<0,05$ ). A Faces Teszt komplex érzelmeinek tulajdonítása szintén minden emlékezeti teszttel szignifikáns pozitív kapcsolatban áll (SzTer: $r=0,4$; FSzTer: $r=0,29$; HMT: $r=0,3$, minden $p<0,05$ ). A korrelációs együtthatókat a 14. táblázatban tüntetjük fel.

14. táblázat: A Faces Teszt és a munkamemória tesztek közötti korrelációs együtthatók az 7-

11 éves életkorú mintában

\begin{tabular}{l|c|c|c}
\hline Munkamemória tesztek & $\begin{array}{c}\text { Számterjedelem } \\
\text { Teszt }\end{array}$ & $\begin{array}{c}\text { Forditott } \\
\text { Számterjedelem } \\
\text { Teszt }\end{array}$ & $\begin{array}{c}\text { Hallási } \\
\text { Mondatterjedelem } \\
\text { Teszt }\end{array}$ \\
\hline \hline Faces Teszt összpontszám & $\mathbf{0 , 4 *}$ & $\mathbf{0 , 3 4 *}$ & $\mathbf{0 , 4 3 *}$ \\
\hline Faces Teszt - alapérzelmek & $\mathbf{0 , 2 1 *}$ & $\mathbf{0 , 2 4 *}$ & $\mathbf{0 , 3 9 *}$ \\
\hline $\begin{array}{l}\text { Faces Teszt }- \text { komplex } \\
\text { érzelmek }\end{array}$ & $\mathbf{0 , 4 *}$ & $\mathbf{0 , 2 9 *}$ & $\mathbf{0 , 3 *}$ \\
\hline
\end{tabular}

Megjegyzés: *: p<0,05; félkövérrel jelölve a szignifikáns korrelációs együtthatók

A parcális korrelációs együtthatók alapján, az életkor kiszürését követően, a Faces Teszt megoldásának sikeressége a munkamemória kapacitásával is összefügg a jelen vizsgálati mintában. A mérsékeltebb korrelációs együtthatók az alapérzelmek felismerése során jelennek meg, ennek oka elsősorban az lehet, hogy ugyan az alapérzelmek felismerése univerzális, azonban a feladat jellegéből adódóan (fénykép alatt két érzelmet leíró szó közül kell 
kiválasztani a helyeset) szükséges lehet a verbális, illetve a komplex munkamemória mozgósítása. Emellett a komplex érzelmek esetében pedig a feladat jellege mellett fontos tényező lehet az is, hogy a komplex érzelmek felismeréséhez vélekedések, szándékok tulajdonítása is szükséges, így ezek a tényezők is megkívánhatják a munkamemória kapacitásának mozgósítását a saját vizsgálatunkban.

Az eredményeink alapján megállapítható, hogy az életkor kontrollálását követően a munkamemória kapacitása pozitív irányban függ össze a tudatelméleti teljesítménnyel, azaz a jobb munkamemória kapacitás magasabb szintü tudatelméleti müködéssel jár együtt. Fontos módszertani szempont tehát, hogy a komplex munkamemória kapacitás (Hallási Mondatterjedelem Teszttel mérve) pozitív összefüggéseket mutat mind a Faux Pas Felismerése Teszten, mind pedig a Faces Teszten elért eredményekkel. Azaz a jelenlegi vizsgálatban szereplő feladatok jellege megkívánja a komplex munkamemória mozgósítását. Az általunk alkalmazott további, munkamemória kapacitást mérő tesztek (Számterjedelem Teszt és Fordított Számterjedelem Teszt) az affektív tudatelméleti teszten elért teljesítménnyel pozitív összefüggést mutatnak, míg azonban a Faux Pas Felismerése Tesztnek csak bizonyos komponenseivel (történetek megértésével) állnak összefüggésben. Tehát eredményeink egyrészt alátámasztják, hogy a jelen vizsgálatban alkalmazott tudatelméleti tesztek a 7-11 éves életkorú mintában megkívánják a munkamemória kapacitás egyidejü mozgósítását, azaz explicit tudatelméleti működést kívánnak meg a vizsgálati személyektől. 


\subsubsection{A tudatelmélet és a munkamemória kapacitás közötti összefüggések vizsgálata a 11-75 éves életkorú mintán}

Az adatok elemzéséhez a tesztek pontozási rendszerét, illetve statisztikai eljárásokat alkalmaztunk. A munkamemória és a tudatelméleti müködés összefüggéseinek vizsgálatát parciális korrelációval ellenőriztük az életkor kontrollálásával. A 15. táblázatban az egyes munkamemória és tudatelméleti teszteken elért átlageredményeket mutatjuk be a 11-75 éves életkorú mintában.

15. táblázat: A tudatelméleti és munkamemória teszteken elért átlageredmények a 11-75 éves életkorú mintában

\begin{tabular}{l|c}
\hline Teszteredmények & Átlag (szórás) \\
\hline Faux Pas Teszt összpontszám & $42,73(1,21)$ \\
\hline Faux Pas Teszt kontrolltörténetek összpontszám & $17,94(0,27)$ \\
\hline Faux Pas Teszt - hamis vélekedés & $6,57(0,21)$ \\
\hline Faux Pas Teszt - affektív mentálisállapottulajdonítás & $7,35(0,21)$ \\
\hline Faces Teszt - alapérzelmek & $9,06(0,19)$ \\
\hline Faces Teszt - bonyolult érzelmek & $8,54(0,12)$ \\
\hline Faces Teszt-összpontszám & $17,94(0,17)$ \\
\hline Számterjedelem Teszt & $5,82(0,1)$ \\
\hline Forditott Számterjedelem Teszt & $4,44(0,1)$ \\
\hline Hallási Mondatterjedelem Teszt & $3,46(0,08)$ \\
\hline
\end{tabular}

\subsubsection{A Faux Pas Felismerése Teszten elért tudatelméleti teljesítmény és a munkamemória kapacitás közötti összefüggések a 11-75 éves életkorú mintában}

A Faux Pas Felismerése Teszt pontozási rendszere alapján a faux pas történetekre vonatkozó összpontszámot, a kontrolltörténetekre vonatkozó összpontszámot és az egyes munkamemóriát mérő teszteken elért teljesítményt vetettük össze parciális korrelációs elemzés segítségével, ahol az életkor változóját kontrolláltuk. A parciális korrelációs elemzés eredményei alapján a faux pas-t tartalmazó történetek összpontszáma a Fordított Számterjedelem Teszttel szignifikáns pozitív korrelációt mutat $(\mathrm{r}=0,3 ; \mathrm{p}<0,05)$, míg a 
Számterjedelem Teszttel tendenciaszintü kapcsolatban áll $(\mathrm{r}=0,16, \quad \mathrm{p}=0,068)$. A kontrolltörténetekre vonatkozó összpontszámmal azonban egyik munkamemória teszten elért eredmény sem korrelál. Az egyes összetevők kapcsán a faux pas-k megértésének kognitív komponense, azaz a hamis vélekedés megértése a Számterjedelem Teszttel $(r=0,19)$ és a Fordított Számterjedelem Teszttel $(\mathrm{r}=0,26)$, továbbá a faux pas-k affektív komponense, vagyis a negatív érzelmi következmények azonosítása is a Számterjedelem Teszttel $(r=0,18)$ és a Fordított Számterjedelem Teszttel $(\mathrm{r}=0,21)$ mutat szignifikáns pozitív korrelációt (minden $\mathrm{p}<0,05)$. A korrelációs együtthatókat a 16. táblázatban mutatjuk be.

16. táblázat. A Faux Pas Felismerése Teszt és a munkamemória tesztek közötti korrelációs együtthatók az 11-75 éves életkorú mintában

\begin{tabular}{l|c|c|c}
\hline \multicolumn{1}{c|}{ Munkamemória tesztek } & $\begin{array}{c}\text { Számterjedelem } \\
\text { Teszt }\end{array}$ & $\begin{array}{c}\text { Forditott } \\
\text { Számterjedelem } \\
\text { Teszt }\end{array}$ & $\begin{array}{c}\text { Hallási } \\
\text { Mondatterjedelem } \\
\text { Teszt }\end{array}$ \\
\hline \hline Faux Pas Teszt összpontszám & $0,16+$ & $\mathbf{0 , 3 *}$ & n.s. \\
\hline $\begin{array}{l}\text { Faux Pas Teszt - kontroll } \\
\text { történetek }\end{array}$ & n.s. & n.s. & n.s. \\
\hline $\begin{array}{l}\text { Faux Pas Teszt - affektív } \\
\text { komponens }\end{array}$ & $\mathbf{0 , 1 8 *}$ & $\mathbf{0 , 2 1 *}$ & n.s. \\
\hline $\begin{array}{l}\text { Faux Pas Teszt- hamis } \\
\text { vélekedés }\end{array}$ & $\mathbf{0 , 1 9 *}$ & $\mathbf{0 , 2 6 *}$ & n.s. \\
\hline
\end{tabular}

Megjegyzés: n.s. $=$ nem szignifikáns, $+: \mathrm{p}<0,1 ; *: p<0,05$; félkövérrel jelölve a szignifikáns korrelációs együtthatók

Az eredmények arra utalnak, hogy a Faux Pas Felismerése Teszt a verbális munkamemóriát mérő Számterjedelem Teszttel, illetve a munkamemóriát mérő Fordított Számterjedelem Teszttel mutat pozitív összefüggéseket jelen vizsgálatban. A korrelációs együtthatók ugyan gyengék illetve mérsékeltek, azonban az megállapítható, hogy mivel a kontrolltörténetekkel egyik emlékezeti teszt sem korrelál, így az elszólást tartalmazó történetekkel kimutatott összefüggések nem az általános szövegfeldolgozásból, illetve történetmegértésből adódó együttjárásból erednek, hanem specifikusan a tudatelméleti müködést megkívánó történetek mutatnak összefüggést a munkamemória kapacitásával. Azaz vizsgálatainkban az életkortól függetlenül a tudatelmélet és a munkamemória kapacitás összefüggései mutathatók ki, ugyanakkor ez a kapcsolat nem a szövegfeldolgozáshoz szükséges munkamemória 
mozgósításából ered, hiszen a tudatelméletet igénybe nem vevő történeteken mutatott teljesítmény nem függött össze a munkamemória kapacitásával.

\subsubsection{2. $\quad$ A Faces Teszten elért tudatelméleti teljesítmény és a munkamemória kapacitás közötti összefüggések a 11-75 éves életkorú mintában}

A Faces Teszt pontozási rendszere alapján a tesztre vonatkozó összpontszám, az alap és a komplex érzelmek felismerésére vonatkozó és az egyes munkamemóriát mérő tesztekkel mért munkamemória kapacitást vetettük össze parciális korrelációs elemzés segítségével, ahol az életkor változóját kontrolláltuk. A parciális korrelációs elemzés eredményei alapján Faces Teszt összpontszáma minden emlékezeti teszt eredményével szignifikáns pozitív korrelációt mutat (SzTer: $r=0,23$; FSzTer: $r=0,29$; HMT: $r=0,42$, minden $p<0,05$ ). A Faces Tesztben az alapérzelmek felismerése szintén minden emlékezeti teszttel szignifikáns pozitív összefüggésben áll (SzTer: $r=0,22$; FSzTer: $r=0,25$; HMT: $r=0,35$, minden $p<0,05$ ). A Faces Teszt komplex érzelmeinek tulajdonítása pedig a Számterjedelem Teszttel tendencia jellegü összefüggést mutat $(\mathrm{r}=0,15 ; \mathrm{p}=0,084$, azonban a Fordított Számterjedelem Teszttel $(\mathrm{r}=0,21)$ és a Hallási Mondatterjedelem Teszttel $(\mathrm{r}=0,32)$ mutat szignifikáns pozitív korrelációt. A korrelációs együtthatókat a 17. táblázatban tüntetjük fel.

17. táblázat. A Faces Teszt és a munkamemória tesztek közötti korrelációs együtthatók az 7-

11 éves életkorú mintában

\begin{tabular}{l|c|c|c}
\hline Munkamemória tesztek & $\begin{array}{c}\text { Számterjedelem } \\
\text { Teszt }\end{array}$ & $\begin{array}{c}\text { Fordított } \\
\text { Számterjedelem } \\
\text { Teszt }\end{array}$ & $\begin{array}{c}\text { Hallási } \\
\text { Mondatterjedelem Teszt }\end{array}$ \\
\hline \hline Faces Teszt összpontszám & $\mathbf{0 , 2 3 *}$ & $\mathbf{0 , 2 9 *}$ & $\mathbf{0 , 4 2 *}$ \\
\hline $\begin{array}{l}\text { Faces Teszt }- \\
\text { alapérzelmek }\end{array}$ & $\mathbf{0 , 2 1 5 *}$ & $\mathbf{0 , 2 5 *}$ & $\mathbf{0 , 3 5 *}$ \\
\hline $\begin{array}{l}\text { Faces Teszt - komplex } \\
\text { érzelmek }\end{array}$ & $0,15+$ & $\mathbf{0 , 2 1 *}$ & $\mathbf{0 , 3 2 *}$ \\
\hline
\end{tabular}

Megjegyzés: $+: \mathrm{p}<0,1 ; *: \mathrm{p}<0,05$; félkövérrel jelölve a szignifikáns korrelációs együtthatók 
A parciális korrelációs együtthatók alapján elmondható, hogy a Faces Teszten elért összteljesítmény és a munkamemória kapacitását mérő eljárások között szignifikáns együttjárás van, ez az összefüggés az alapérzelmek és a komplex érzelmek felismerése esetében is megjelenik, ugyanakkor a komplex érzelmek felismerése esetében a verbális munkamemóriával való összefüggés tendenciajellegü. Összességében a Faces Teszttel mért affektív tudatelméleti teljesítmény és a komplex munkamemóriát mérő Hallási Mondatterjedelem Teszt között a legerősebbek az összefüggések. Eredményeink szerint tehát az affektív tudatelméleti müködés a komplex munkamemória kapacitásával van összefüggésben, azaz a jobb munkamemória kapacitás magasabb affektív tudatelméleti teljesítménnyel jár együtt saját vizsgálati mintánkban.

Jelen vizsgálatban, a teljes mintában az életkor kontrollálását követően, mind a gyermek, mind a felnőtt tesztváltozattal mért komplex (kognitív és affektív), illetve az affektív tudatelméleti teljesítmény és a munkamemória egyes komponensei között összefüggések mutathatók ki. Életkortól függetlenül kimutatható, hogy míg a Faces Teszt minden emlékezeti teszttel korrelál, addig a Faux Pas Felismerése Teszt gyermek változatán elért eredmény a komplex munkamemória teszttel (Hallási Mondatterjedelem), míg a felnőtt tesztváltozattal mért teljesítmény és egyes összetevői mind a verbális, mind a komplex munkamemória kapacitással (Számterjedelem és Fordított Számterjedelem Teszte) pozitív összefüggésben állnak. Azaz a Faces Teszt sikeres megoldása összefüggésben áll a munkamemória kapacitással. A Faux Pas Teszt gyermekváltozata esetében a történetek megértésére vonatkozó kontrollkérdés mutat erőteljes összefüggést minden emlékezeti teszttel, ugyanakkor a felnőtt változatban a tudatelmélet mozgósítását nem igénylő, kontrolltörténetek nem mutatnak összefüggést a munkamemória kapacitással. Mindez jelezheti azt, hogy a felnőtt tesztváltozattal mért mintában az egyszerü szövegfeldolgozás nem, de a tudatelmélet mozgósítását igénylő feladatok sikeres megoldása együttjár a munkamemória kapacitás jobb színvonalával, tehát a tudatelméleti müködés jár együtt elsősorban a munkamemória kapacitással a jelen vizsgálat eredményei alapján. 
A kimutatott összefüggések gyengék vagy mérsékeltek ugyan, azonban mindegyik pozitív irányú, azaz a jobb emlékezeti kapacitás jobb tudatelméleti müködéssel jár együtt. Ez fontos módszertani kérdéseket vethet fel a továbbiakban, ugyanakkor megerősíti azt a tényt, hogy bizonyos társas kognícióval kapcsolatos folyamatok explicitek, azaz nagyobb kognitív terheléssel járnak, jobban igénybe veszik az egyén kognitív erőforrásait (Frith és Frith, 2008; Apperly, 2011), ahogyan saját vizsgálataink eredményei is ezt alátámasztják. 


\subsection{A harmadik vizsgálatban kapott eredmények ismertetése}

Feltételezéseink szerint a tudatelméleti működés és társas pozíció között mutatható ki kapcsolat a korábbi, ugyanakkor ellentmondásos eredmények tükrében. Harmadik vizsgálatunkba 8-14 éves iskoláskorú diákokat vontunk be, a társas pozíció mérésére pedig a korábbi kutatásokban (Banerjee és Watling, 2005; Banerjee, Watling és Caputi, 2011) is alkalmazott egyszerü választásos szociometriai módszert alkalmaztuk, melynek során három pozitív és három negatív választást kértünk a gyermekekröl, majd az egyes gyermekekre adott választásokat összesítettük és három módszerrel elemeztük (részletesebben 9.3.1. fejezetben ismertettük). A vizsgálatunkban a tudatelméleti tesztek közül a Faux Pas Felismerése Teszt gyermek (Baron-Cohen és mtsai, 1999) és felnőtt változatát (Stone és mtsai, 1998), valamint az affektív tudatelméleti komponens mérésére a Faces Tesztet alkalmaztuk. A 8-10 éves gyermekek körében a gyermek, míg a 12-14 éves gyermekek körében pedig a felnőtt változatot alkalmaztuk, hiszen tapasztalataink szerint már serdülökorban sikeresen alkalmazható (Gál, Egyed, Pászthy és Németh, 2011). A továbbiakban a tudatelméleti képesség, a munkamemória kapacitás, illetve a szociometriai pozíció közötti kapcsolatot vizsgáltuk meg. A szociometriai pozíció három különböző csoportosításával kapcsolatos eredményeket a továbbiakban külön ismertetjük.

\subsubsection{A szociometriai pozíció és a tudatelméleti müködés közötti összefüggések vizsgálata az egyszerü csoportosítás alapján}

Vizsgálatainkban minden egyes gyermekek esetében, az osztálytársaktól kapott pozitív és negatív választásokat összesítettük, majd a pozitív és negatív választások egymáshoz viszonyított száma alapján csoportokat hoztunk létre. A népszerü csoportba tartoztak azok a gyerekek, akiknek több pozitív választásuk volt, míg az ambivalens gyerekek ugyanannyi pozitív, mint negatív választással rendelkeztek, továbbá az elutasított gyermekek csoportjába kerültek azok, akik több negatív, mint pozitív választást kaptak az osztálytársaktól (9.3.1. fejezet). A három lehetséges pozíció közül azonban csak a népszerü és az elutasított pozíciójú gyerekekkel végeztük az elemzéseket, mivel az ambivalens csoportba tartozók száma nagyon alacsony volt, így őket a további elemzésekből kizártuk. A 18. táblázatban ismertetjük az egyes szociometriai pozícióba tartozó gyermekek elemszámát. 
18. táblázat. Az egyszerü szociometriai csoportosítással kapott pozíciók eloszlása (fö)

\begin{tabular}{l|c|c|c}
\hline \multicolumn{1}{c|}{ Korosztály } & Népszerü & Ambivalens & Elutasított \\
\hline \hline 8-10 éves & 49 & 15 & 31 \\
\hline $12-14$ éves & 24 & 1 & 12 \\
\hline
\end{tabular}

Az ambivalens csoportok kis elemszáma miatt a népszerünek és elutasítottnak kategorizált gyerekek tudatelméleti teszten, illetve a munkamemória teszten elért átlageredményeit vetettük össze kétmintás t-próbával.

A 8-10 éves korosztályban az elemzés szerint egyik tudatelméleti képességet mérő teszt vagy azok összetevői sem mutatnak szignifikáns különbségeket a népszerüként és elutasítottként kategorizált gyermekek között (Faux Pas: népszerü átlag=3,4, szórás=0,29; elutasított átlag $=3,3$, szórás $=0,31 ; \mathrm{t}(81)=0,126, \mathrm{p}=0,9$; Faces: népszerű átlag $=16,16$, szórás $=0,26$; elutasított átlag $=15,86$, szórás $=0,25 ; \mathrm{t}(81)=0,75, \mathrm{p}=0,46)$. Ugyanakkor a számlálási terjedelem teszttel mért munkamemória kapacitás szignifikánsan eltér a népszerü és az elutasított gyermekek között (népszerü átlag=2,8, szórás $=0,14$; elutasított átlag=2,35, szórás $=0,15 ; \mathrm{t}(81)=2,215, \mathrm{p}=0,03)$. Az eredmények alapján megállapítható, hogy az általunk alkalmazott csoportosítás alapján a tudatelméleti tesztek eredményei nem, azonban a munkamemória kapacitása mutat különbségeket a népszerü és az elutasított gyermekek mintájában a 8-10 éves korosztályban, az iskola alsó tagozatán.

A 12-14 évesek csoportjában hasonló eredményeket kapunk a tudatelméleti képességekre vonatkozóan, a kétmintás t-próba alapján nincs szignifikáns különbség a népszerü (Faux Pas: átlag=31,25, szórás=3,9; Faces: átlag=18, szórás=0,3) és az elutasított (Faux Pas: átlag=30,25, szórás $=4,4$; Faces: átlag=17,75, szórás $=0,54$ ) gyermekek csoportjai között (Faux Pas: t(34)=0,158, p=0,87; Faces: t(34)=0,51, p=0,614). Ugyanakkor az alsó tagozatos diákokhoz képest különbség, hogy a munkamemória kapacitás sem különbözik szignifikánsan a népszerü és az elutasított gyermekek között $(\mathrm{t}(34)=1,25 ; \mathrm{p}=0,22)$. Vagyis a vizsgált mintában a felső tagozatos diákok között sem a tudatelméleti képességek, sem a munkamemória kapacitás nem differenciál a szociometriai pozíció tekintetében. Míg az alsó tagozatosok esetében a munkamemória fontos differenciáló tényező, addig felső tagozatban ez már nem jelentős a gyerekek által megítélt szociometriai pozíció tekintetében. Az általunk vizsgált mintában, az alsó tagozatban a kognitív funkciók szignifikánsan magasabb színvonalúak a népszerünek osztályozott gyerekek körében az elutasított gyermekekhez viszonyítva, azonban felső tagozatban ez a különbség már nem szignifikáns, vagyis a 
népszerüség és a kognitív funkciók közötti összefüggés nem jelenik meg az idősebb korosztályban.

Az egyszerü csoportosítás kapcsán felmerül az a kérdés, hogy a pozitív és a negatív választások számát nem vesszük figyelembe a csoportosítás során, pusztán a pozitív és negatív választások egymáshoz viszonyított számát. Ennek a problémának a kiküszöbölésére alkalmaztuk Banerjee és Watling (2005) kutatásában alkalmazott szociometriai elemzési módszert kutatási kérdéseink tisztázására.

\subsubsection{A szociometriai pozíció és a tudatelméleti működés közötti összefüggések vizsgálata a sztenderdizált mutatók alapján}

A Banerjee és Watling (2005) kutatásában alkalmazott elemzési módszert részletesen a 9.3.1. fejezetben ismertettük. Az elemzés alapján a minden osztályban kapott pozitív és negatív választások standardizált értékeiből, és az ezekből az értékekből kiszámolt társas preferencia és társas befolyás változókból 5 csoportba sorolhatók a vizsgálati személyek a szociometriai mérés alapján. Az eloszlásokat a 19. táblázatban ismertetjük.

19. táblázat. A szociometriai pozíciók eloszlása a mintában (fö)

\begin{tabular}{l|c|c|c|c|c}
\hline \multicolumn{1}{c|}{ Korosztály } & Népszerü & Elutasitott & Ambivalens & Elhanyagolt & Semleges \\
\hline \hline $8-10$ éves & 30 & 21 & 7 & 19 & 23 \\
\hline $12-14$ éves & 8 & 6 & 1 & 8 & 14 \\
\hline
\end{tabular}

Az eloszlások vizsgálata alapján az ambivalens csoportot itt sem vesszük figyelembe az elemzések során, a kis elemszám miatt. A továbbiakban a népszerü, az elutasított, az elhanyagolt és az semleges szociometriai pozíciójú gyermekek tudatelméleti és munkamemória teszten elért átlageredményeit hasonlítjuk össze egyszempontos varianciaanalízis segítségével.

A 8-10 éves korosztályban egyik tudatelméleti teszten és azok összetevőinek kapcsán sem mutatható ki szignifikáns különbség az egyes szociometriai csoportok között (az átlagértékeket és a statisztikai mutatókat a 19. táblázatban közöljük). Ugyanakkor a munkamemória kapacitás esetében szintén kimutatható az előző csoportosítás alapján is megjelenő mintázat, azaz szignifikáns szociometriai csoportfőhatás mutatható ki a számlálási terjedelem teszten elért eredmény tekintetében $(F(3 ; 86)=2,475, p=0,035)$. A semleges 
gyerekek számlálási terjedelme szignifikánsan magasabb színvonalú az elutasított $(p=0,011)$ és az elhanyagolt gyerekekéhez képest $(\mathrm{p}=0,017)$, a népszerü gyerekek teljesítménye pedig a semleges és az elutasított gyermekek között helyezkedik el, azonban nem tér el szignifikánsan a semleges csoportba tartozó gyerekek teljesítményétől. Az átlegértékeket és a statisztikai mutatókat a 20. táblázatban tüntetjük fel.

20. táblázat a tudatelméleti képesség és a munkamemória kapacitás eltérései a szociometriai pozíció függvényében a 8-10 éves korosztályban

\begin{tabular}{l||c|c|c|c|c}
\hline \multicolumn{1}{c|}{ Szociometriai pozíció } & $\begin{array}{c}\text { Népszerü } \\
\text { átlag } \\
\text { (szórás) }\end{array}$ & $\begin{array}{c}\text { Elutasitott } \\
\text { átlag } \\
\text { (szórás) }\end{array}$ & $\begin{array}{c}\text { Elhanyagolt } \\
\text { átlag (szórás) }\end{array}$ & $\begin{array}{c}\text { Semleges } \\
\text { átlag (szórás) }\end{array}$ & $\mathrm{F}(\mathrm{p})$ \\
\hline $\begin{array}{l}\text { Faux Pas } \\
\text { összpontszám }\end{array}$ & $3,37(0,4)$ & $3,38(0,46)$ & $4(0,45)$ & $3,68(0,4)$ & $\begin{array}{c}\mathrm{F}(3 ; 86)=0,418 \\
\mathrm{p}=0,74\end{array}$ \\
\hline $\begin{array}{l}\text { Faux Pas - } \\
\text { elszólás detektálása }\end{array}$ & $7(0,4)$ & $6(0,64)$ & $6,65(0,34)$ & $7,27(0,43)$ & $\begin{array}{c}\mathrm{F}(3 ; 86)=1,187 \\
\mathrm{p}=0,318\end{array}$ \\
\hline $\begin{array}{l}\text { Faux Pas - vélekedés } \\
\text { hamis } \\
\text { megértése }\end{array}$ & $7,47(0,3)$ & $7,43(0,5)$ & $7,7(0,45)$ & $7,68(0,34)$ & $\begin{array}{c}\mathrm{F}(3 ; 86)=0,157 \\
\mathrm{p}=0,925\end{array}$ \\
\hline $\begin{array}{l}\text { Faces Teszt- } \\
\text { összpontszám }\end{array}$ & $15,77(0,32)$ & $16,1(0,28)$ & $15,59(0,4)$ & $16,3(0,37)$ & $\begin{array}{c}\mathrm{F}(3 ; 86)=0,872 \\
\mathrm{p}=0,459\end{array}$ \\
\hline $\begin{array}{l}\text { Faces Teszt- } \\
\text { alapérzelmek }\end{array}$ & $8,6(0,23)$ & $8,9(0,2)$ & $8,5(0,25)$ & $8,9(0,2)$ & $\begin{array}{c}\mathrm{F}(3 ; 86)=0,8 \\
\mathrm{p}=0,497\end{array}$ \\
\hline $\begin{array}{l}\text { Faces Teszt- } \\
\text { komplex érzelmek }\end{array}$ & $7,2(0,23)$ & $7,2(0,3)$ & $7,06(0,35)$ & $7,4(0,32)$ & $\begin{array}{c}\mathrm{F}(3 ; 86)=0,284 \\
\mathrm{p}=0,837\end{array}$ \\
\hline $\begin{array}{l}\text { Számlálási terjedelem } \\
\text { teszt }\end{array}$ & $2,64(0,14)$ & $2,27(0,2)$ & $2,3(0,2)$ & $2,98(0,23)$ & $\begin{array}{c}\mathrm{F}(3 ; 86)=2,659 \\
\mathrm{p}=0,05\end{array}$ \\
\hline
\end{tabular}

A második típusú csoportosítás alapján (Banerjee és Watling, 2005) a tudatelméleti tesztek eredményei nem, azonban a munkamemória kapacitása különbséget mutat a szociometriai pozíció tekintetében a 8-10 éves korosztályban, az iskola alsó tagozatán. A 1214 éves korosztályban egyik tudatelméleti teszten és azok összetevőinek kapcsán sem mutatható ki szignifikáns különbség az egyes szociometriai csoportok között, valamint a munkamemória kapacitás sem különbözik jelentősen az egyes szociometriai pozíciók szerinti csoportosítás között (az átlagértékeket és a statisztikai mutatókat a 21. táblázatban közöljük). 
21. táblázat a tudatelméleti képesség és a munkamemória kapacitás eltérései a szociometriai pozíció függvényében a 12-14 éves korosztályban

\begin{tabular}{l||c|c|c|c|c}
\hline \multicolumn{1}{c|}{ Szociometriai pozíció } & $\begin{array}{c}\text { Népszerü } \\
\text { átlag (szórás) }\end{array}$ & $\begin{array}{c}\text { Elutasitott } \\
\text { atlag (szórás) }\end{array}$ & $\begin{array}{c}\text { Elhanyagolt } \\
\text { átlag (szórás) }\end{array}$ & $\begin{array}{c}\text { Semleges } \\
\text { átlag (szórás) }\end{array}$ & $\begin{array}{c}\text { Statisztika } \\
\mathrm{F}(\mathrm{p})\end{array}$ \\
\hline $\begin{array}{l}\text { Faux Pas } \\
\text { összpontszám }\end{array}$ & $33,63(6,4)$ & $25,5(6,9)$ & $32,6(6,8)$ & $31,9(5)$ & $\begin{array}{c}\mathrm{F}(3 ; 32)=0,258 \\
\mathrm{p}=0,855\end{array}$ \\
\hline $\begin{array}{l}\text { Faux Pas - kontroll } \\
\text { történetek } \\
\text { összpontszám }\end{array}$ & $18,25(0,7)$ & $18,17(1,2)$ & $18,5(0,7)$ & $18,6(0,6)$ & $\begin{array}{c}\mathrm{F}(3 ; 32)=0,065 \\
\mathrm{p}=0,978\end{array}$ \\
\hline $\begin{array}{l}\text { Faux Pas - } \\
\text { hamis } \\
\text { megértése }\end{array}$ & $5,75(1,06)$ & $4,5(1,2)$ & $5,38(1,1)$ & $5,3(0,87)$ & $\begin{array}{c}\mathrm{F}(3 ; 32)=0,187 \\
\mathrm{p}=0,905\end{array}$ \\
\hline $\begin{array}{l}\text { Faux Pas }- \\
\text { affektív komponens }\end{array}$ & $5,5(1,09)$ & $4,33(1,26)$ & $5,5(1,09)$ & $5,2(0,87)$ & $\begin{array}{c}\mathrm{F}(3 ; 32)=0,21 \\
\mathrm{p}=0,89\end{array}$ \\
\hline $\begin{array}{l}\text { Faces Teszt- } \\
\text { összpontszám }\end{array}$ & $18,87(0,58)$ & $17,5(0,88)$ & $18,1(0,58)$ & $17,5(0,31)$ & $\begin{array}{c}\mathrm{F}(3 ; 32)=1,51 \\
\mathrm{p}=0,231\end{array}$ \\
\hline $\begin{array}{l}\text { Faces Teszt- } \\
\text { alapérzelmek }\end{array}$ & $9,12(0,39)$ & $8,5(0,43)$ & $8,87(0,35)$ & $8,86(0,33)$ & $\begin{array}{c}\mathrm{F}(3 ; 32)=0,349 \\
\mathrm{p}=0,79\end{array}$ \\
\hline $\begin{array}{l}\text { Faces Teszt- } \\
\text { komplex érzelmek }\end{array}$ & $9,75(0,45)$ & $9(0,63)$ & $9,25(0,3)$ & $8,64(0,29)$ & $\begin{array}{c}\mathrm{F}(3 ; 32)=1,577 \\
\mathrm{p}=0,214\end{array}$ \\
\hline $\begin{array}{l}\text { Számlálási terjedelem } \\
\text { teszt }\end{array}$ & $2,44(0,26)$ & $1,9(0,07)$ & $2,9(0,29)$ & $2,7(0,24)$ & $\begin{array}{c}\mathrm{F}(3 ; 32)=2,24 \\
\mathrm{p}=0,103\end{array}$ \\
\hline
\end{tabular}

A négy szempont alapján történő csoportosítás során négy szociometriai csoportot vontunk be az elemzésbe az alsó és a felső tagozatos diákok körében is. Míg a tudatelméleti teszteken nincs különbség a szociometriai pozícióban, vagyis ebben az értékelési rendszerben nem mutatható ki az, miszerint a népszerü gyerekeknek magasabb a tudatelméleti teszteken elért eredménye. Az az összefüggés rajzolódik ki, miszerint a népszerü és semleges szociometriai pozíciójú gyerekeknek magasabb a munkamemória kapacitása, azonban ez az összefüggés csak az alsó tagozatos korosztályban mutatható ki, a felső tagozatos gyermekek körében már nem jelentkezik ez a kapcsolat a vizsgált mintában. 


\subsubsection{A társak általi elfogadottság vagy elutasítottság és a tudatelméleti müködés közötti összefüggések vizsgálata korrelációs elemzéssel}

A harmadik értékelési módszer alapjául Banerjee és Watling (2005), illetve Banerjee, Watling és Caputi (2011) vizsgálata szolgált, ahol a pozitív és a negatív választások alapján nem szociometriai csoportokat alakítottak ki, hanem létrehozták a társak általi elfogadottság (peer acceptance) és az elutasítottság (peer rejection) változókat. A változók folytonos változóknak tekinthetők, hiszen a pozitív és a negatív választások standardizált értékeiből kerültek kialakításra, ezt részletesen a 9.3.1. fejezetben ismertettük. Az elfogadottság és elutasítottság mértéke és a tudatelméleti képesség összefüggéseit Pearson-korrelációval elemeztük.

A 8-10 évesek életkori csoportjában szignifikáns korreláció nem mutatható ki, egy tendencia jellegű negatív korreláció rajzolódik ki a Faux Pas Felismerése Teszt első kérdésének, az elszólások detektálása és a társak általi elutasítottság között $(\mathrm{r}=-0,18, \mathrm{p}=0,08)$. A 10.3.2. fejezetben ismertetett szociometriai csoportosítás mellett Banerjee és Watling (2005) kutatásukban megvizsgálták a társas preferencia és a társas befolyás változók a tudatelméleti képességgel való kapcsolatát. Kutatásunkban $\mathrm{mi}$ is elvégeztük a korrelációelemzést, amelynek eredményeként szignifikáns korreláció nem, csak tendencia jellegủ együttjárás mutatható ki a társas preferencia változója és a számlálási terjedelem teszt eredménye $(\mathrm{r}=0,19, \mathrm{p}=0,06)$ között, illetve az elszólások detektálása és társas preferencia változó között gyenge, szignifikáns kapcsolat mutatható ki $(\mathrm{r}=0,2, \mathrm{p}=0,05)$ az alsó tagozatos gyerekek körében.

A 12-14 éves korosztályban markánsabb összefüggések rajzolódnak ki a társak általi elfogadottság és a tudatelméleti képesség között. A társas elfogadottság, azaz a pozitív választások standardizált értéke és az affektív tudatelméleti képességet mérö Faces Teszt összpontszáma között szignifikáns pozitív korreláció mutatható ki ( $\mathrm{r}=0,381)$, a komplex érzelmek felismerésével tendencia jellegủ az összefüggés ( $\mathrm{r}=0,297, \mathrm{p}=0,07)$. Kutatásunkban elvégeztük a korrelációelemzést a társas befolyás és a tudatelméleti képesség, illetve a társas preferencia és a tudatelméleti képesség közötti összefüggések vizsgálatára. Jelen mintában a felső tagozatosok körében nem mutatkozik szignifikáns korreláció a Faux Pas Felismerése 
Teszt összpontszáma és a társas preferencia és a társas befolyás változók között, csakúgy a Faux Pas Teszt egyes kérdései sem korrelálnak szignifikánsan ezekkel a változókkal. Ugyanakkor a Faces Teszt összpontszáma és a társas befolyás $(\mathrm{r}=0,324)$, illetve a Faces Teszt komplex érzelmek felismerése és a társas befolyás $(\mathrm{r}=0,371)$ változók között szignifikáns pozitív összefüggés mutatható ki (minden $\mathrm{p}<0,05$ ), a társas preferencia változókkal azonban nem található szignifikáns kapcsolat. A Faces Teszt alapérzelmek felismerése pedig sem a társas befolyás, sem a társas preferencia változóval nem korrelál szignifikánsan. Összességében tehát mintánkban a felső tagozatos diákok között az affektív tudatelméleti komponens áll összefüggésben a társas befolyás (a gyermekre adott összes választások száma) illetve a standardizált pozitív választások változójával, míg az alsó tagozatosok körében nem találhatunk szignifikáns, csak gyenge, tendencia jellegű összefüggéseket. A szignifikáns és a tendencia jellegü korrelációs együtthatókat a 22. táblázatban ismertetjük.

22. táblázat. A társas preferencia/befolyás, a standardizált pozitív/negatív választások és a tudatelméleti képesség közötti korrelációs együtthatók

\begin{tabular}{|c|c|c|c|c|c|}
\hline & & $\begin{array}{r}\text { Társas } \\
\text { preferencia }\end{array}$ & $\begin{array}{c}\text { Társas } \\
\text { befolyás }\end{array}$ & $\begin{array}{c}\text { Standardizált } \\
\text { pozitív } \\
\text { választások } \\
\end{array}$ & $\begin{array}{c}\text { Standardizált } \\
\text { negatív } \\
\text { választások } \\
\end{array}$ \\
\hline $\begin{array}{c}\text { 8-10 } \\
\text { éves } \\
\text { korosztály }\end{array}$ & $\begin{array}{l}\text { Faux Pas - } \\
\text { elszólás } \\
\text { detektálása }\end{array}$ & $0,2 *$ & n.s. & n.s. & - $0,18+$ \\
\hline \multirow{2}{*}{$\begin{array}{c}\text { 12-14 } \\
\text { éves } \\
\text { korosztály }\end{array}$} & $\begin{array}{l}\text { Faces Teszt - } \\
\text { összpontszám }\end{array}$ & n.s. & $0,32 *$ & $0,38 *$ & n.s. \\
\hline & $\begin{array}{l}\text { Faces Teszt - } \\
\text { komplex } \\
\text { érzelmek }\end{array}$ & n.s. & $0,37 *$ & $0,3+$ & n.s. \\
\hline
\end{tabular}

Megjegyzés: n.s.: nem szignifikáns; *: p<0,05 (félkövérrel jelölve a szignifikáns korrelációs együtthatók

Összességében a kutatás során kapott eredmények megerősítik az eddig is vizsgált, a tudatelméleti müködés és a szociometriai státusz közötti ellentmondásos összefüggéseket. Míg jelen vizsgálatban a szociometriai pozíció szerinti csoportosításban nincs szignifikáns eltérés abban az irányban, hogy a népszerübb gyerekek jobb, illetve az elutasított gyerekek alacsonyabb színvonalú tudatelméleti müködéssel jellemezhetők egyik korosztályban sem. A társas preferencia és befolyás, illetve a pozitív és a negatív választások értékei esetében 
szignifikáns korrelációk mutathatók ki, elsősorban az idősebb korosztályban. A megelőző vizsgálatokban is a kimutatott összefüggések elsősorban az idősebb korosztályban jelentek meg (5-6 éveseknél nem, míg a 8-9 éveseknél kimutathatók korrelációs együtthatók, Banerjee és Watling, 2005). Saját vizsgálatunkban a 8-10 évesek esetében csak tendenciajellegüek az összefüggések, ezek arra utalnak, hogy a magasabb szintű társak általi elutasítottság az elszólások detektálásának alacsonyabb színvonalával jár együtt, illetve a magasabb társas preferencia magasabb színvonalú elszólás felismeréssel jár együtt tendenciaszinten, gyenge összefüggéseket mutatva. Ugyanakkor az idősebb korosztályban a magasabb szintü társak általi elfogadottság, és a társakra történő befolyás magasabb színvonalú affektív tudatelméleti müködéssel jár együtt. Vagyis az eredményeink alapján azok a 12-14 éves gyerekek, akiknek a társas működése a szociometriai módszer alapján magasabb színvonalú, magasabb affektív tudatelméleti képességgel jellemezhetők. Specifikusan az affektív tudatelmélet vizsgálatára az általunk áttekintett kutatások nem tértek ki, vagyis eredményeink mindenképpen figyelemre méltók a társas pozíció és a tudatelmélet kapcsolatában.

Ugyanakkor jelen vizsgálatunk alapján a szociometriai pozíció tekintetében nem mutathatók ki eltérések a tudatelméleti müködésben, mindez pedig felveti annak kérdését, hogy a szociometriai pozícióban az alsó tagozatos gyermekek körében inkább a kognitív funkciók a meghatározók, míg felső tagozatban már nem, ugyanakkor a tudatelméleti képesség sem lesz meghatározó a szociometriai pozíció tekintetében. Feltehetően a szociometriai pozícióban, illetve a pozitív és a negatív választásokban más meghatározó tényezők is közrejátszanak, így érdemes lehet a további vizsgálatokban más faktorokat is bevonni (pl. a SES-re vonatkozó adatok), illetve egyéb, a társas hatékonyságot meghatározó módszerekkel is mérni a társas viselkedést, például több szempontú szociometria, illetve más szociális kompetenciát mérő eszközök alkalmazásával, melyek a társas hatékonyság különböző aspektusait képesek megragadni. 


\section{AZ EREDMÉNYEK ÖSSZEGZÉSE, KITEKINTÉS ÉS TOVÁBBI KUTATÁSI IRÁNYOK}

A disszertáció egyik fö célja volt, hogy vizsgálatsorozatunkkal képet kaphassunk a tudatelméleti képesség mérési lehetőségeiről az iskolás gyerekek korosztályában, a serdülö- és felnőttkorban egyaránt. Ennek mentén az explicit tudatelmélet életkori különbségeinek, kognitív funkciókkal (a munkamemória kapacitással), és a társas pozícióval való kapcsolatának jellemzőit szerettük volna feltárni. A kutatások során a saját fordításban alkalmaztuk a Faux Pas Felismerése Teszt gyermek (Baron-Cohen és mtsai, 1999) és felnőtt változatát (Stone, Baron-Cohen és Knight, 1998), melyek a külföldi vizsgálati eredmények tudatában jól alkalmazható mérőeszköznek bizonyultak. A disszertációban három vizsgálatunk szerepel, az első a tudatelmélet életkori különbségeit, a második a munkamemória kapacitással való kapcsolatát, a harmadik pedig a társas pozícióval való összefüggéseit vizsgálta.

\subsection{A tudatelméleti képesség életkori különbségei}

Az első vizsgálatban arra kerestük a választ, hogy a tudatelméleti teljesítményben milyen életkori különbségek mutathatók ki egy széles életkori spektrumon. A vizsgálatot két almintán végeztük el, melynek elsősorban módszertani okai voltak. A Faux Pas Felismerése Teszt gyermek változata 7-11 éves korban alkalmas a tudatelmélet mérésére (Baron-Cohen és mtsai, 1999), míg a felnőtt változattal kapcsolatban kérdés, hogy milyen életkortól mér megfelelően, saját vizsgálati tapasztalataink szerint már serdülőkorban is alkalmazható (Gál, Egyed, Pászthy és Németh, 2011). Egy 5-11 éves életkori és egy 11-75 éves életkori spektrumba tartozó személyekkel végeztük a vizsgálatainkat, az első almintában a gyermek, a 11-75 éves almintában pedig a felnőtt tesztváltozatot alkalmaztuk. 
A Faux Pas Felismerése Teszt tekintetében eredményeink szerint az 5-11 éves korosztályba tartozó mintában az elért összteljesítmény esetében a legfiatalabb életkori csoportba tartozó gyerekek teljesítenek a legalacsonyabb színvonalon, a 7-8 éves korosztálynál és a náluk idősebbeknél már nem változik jelentős mértékben a gyermekek teljesítménye. Az eredeti tesztváltozat kialakítása során a szerzők azonban hét, kilenc és tizenegy éves korú életkori csoportok között is találtak teljesítményemelkedést (Baron-Cohen és mtsai, 1999), ugyanakkor az általunk vizsgált nagyobb elemszámú mintában ez nem vált egyértelművé, saját vizsgálataink eredménye szerint a 7-8 éves gyerekek teljesítményéhez hasonlóan teljesítenek a 9-10-11 éves gyerekek a teszt értékelésének eredeti változata szerint. A vizsgálatban részt vevő 11-75 éves mintában az eredmények azt mutatják, hogy a Faux Pas Felismerése Teszt felnőtt változatának összpontszáma 11 és 12 éves kor között teljesítményemelkedést mutat, majd a 13-17 éves korosztálytól enyhe teljesítménycsökkenés jelentkezik, a tudatelméleti teszttel mért teljesítmény idős, 60-75 éves korosztályban a legalacsonyabb, minden fiatalabb életkori csoporthoz képest. A kontrolltörténetekben nincs szignifikáns különbség a 6 életkori csoport között jelen vizsgálatban, azaz az életkorból eredő különbségek valóban a tudatelméleti müködésben jelentkező eltérések, nem pedig az általános történetmegértésböl fakadnak.

A gyermek tesztváltozatban a Faux Pas Felismerése Teszt összpontszámán kívül lehetőségünk van részletesebb elemzéseket is végezni az elszólást tartalmazó történeteket követően feltett kérdésekre adott válaszok alapján. Így három változót elemeztünk, az elszólás detektálását, a történet megértését és a hamis vélekedés megértését. Az elszólások detektálása kapcsán fontos tényező, hogy az átlagértékek alapján feltehetően nem pusztán találgatás alapján adtak választ a vizsgálati személyek. Ennek tudatában érdekes eredmény, hogy vizsgálatunkban a legfiatalabb korosztály is a véletlen szintje felett teljesített, ami jelezheti azt is, hogy a gyerekek már 5-6 éves korban képesek felismerni, hogy valaki elkövetett egy elszólást, azonban ennek indoklása, illetve a mögöttes szándékok kikövetkeztetése még nehéz lehet számukra. Ennek kapcsán tisztábban láthatunk az elszólás mögötti hamis vélekedés megértésével kapcsolatos kérdésekre adott válaszokból. A vizsgált mintában az 5-6 évesektől a 9 éves korosztályig egyre magasabb teljesítményt érnek el a gyerekek, a 10 és a 11 éves korosztályban ez a teljesítmény alacsonyabb szintűvé válik. Ennek magyarázata egyrészt abból is eredhet, hogy 10-11 éves korban a hamis vélekedés tulajdonítása feltehetően már automatikusan müködik, nem differenciál megfelelően, illetve teljesítményromlás is 
jelentkezhet. A 10-11 évesek alacsonyabb teljesítményének magyarázatában fontos lehet a történetek megértésének vizsgálata, hogy valójában mennyire érthették meg, mennyire figyeltek a gyerekek az adott történetekre, melyet a történeteket követő harmadik kérdésre adott helyes válaszokkal ellenőrizhetünk. Ennek a kérdésnek a tekintetében a 9 évesek teljesítménye a legmagasabb, azaz az elszólások mögötti hamis vélekedés megértésének 9 évesek esetében kimutatható magas szintü teljesítménye akár a jobb történetre való odafigyeléssel állhat összhangban. Az eredmények szerint a 10 és 11 éves gyerekek történet megértése magasabb színvonalú az 5-6 éves gyerekekéhez képest, azaz a 10-11 évesek esetében az elszólás mögötti hamis vélekedés megértésének alacsonyabb színvonala nem a rosszabb történet megértési teljesítmény miatt lehet, sokkal inkább a hamis vélekedés megértésének automatizmusa okozhatja a teljesítmény alacsonyabb színvonalát ebben az általunk vizsgált korosztályban. Összességében elmondható, hogy a történetek megértésében, a történésekre való figyelem tekintetében a 9 évesek átlageredménye emelkedik ki a többi korcsoport közül, továbbá már az 5-6 éves gyerekek is a véletlen szintje fölött képesek detektálni (de nem feltétlenül megérteni) a társas helyzetben elkövetett elszólásokat, illetve az elszólások mögötti hamis vélekedés tulajdonítás a 9 éves gyerekek körében a legmagasabb az öt vizsgált életkori csoport között. A fejlődésben korábbi életkorban jelenik meg a beágyazott mentális állapotok tulajdonítása, ennek tükrében érdekes, hogy a másodfokú hamisvélekedésteszt sikeres megoldása sikeresebb faux pas megértést eredményez az 5-11 éves korosztályban. Eredményeink igazolják, hogy azok a tipikus fejlődésű gyerekek, akik képesek megoldani az első-, illetve a másodfokú hamisvélekedés-teszteket, nagyobb valószínűséggel képesek megoldani egy bonyolultabb, összetettebb tudatelméleti képességet igénylő feladatot, jelen vizsgálatban a Faux Pas Felismerése Tesztet (Baron-Cohen és mtsai, 1999).

A Faux Pas Felismerése Teszt felnőtt változatában is lehetőségünk van részletesebb elemzésre. Az elszólások magyarázatában a hamis vélekedés megértését és az affektív mentálisállapot-tulajdonítást külön is értelmezhetjük. A vizsgálatban részt vevő 11-75 éves korosztály esetében a faux pas összpontszámhoz hasonlóan az a tendencia érvényesül, hogy az elszólások mögötti hamis vélekedés megértésében az időskorra jelentősen romlik a teljesítmény. Az idős korosztály teljesítménye a legalacsonyabb a mintán belül az elszólást követő negatív érzelmi következmények, vagyis az affektív mentálisállapot-tulajdonítás tekintetében. Azaz a faux pas megértésének kognitív és affektív komponense is hanyatlik az életkor előrehaladtával, melyek megerősítik az idősekkel kapcsolatos korábbi kutatási 
eredményeket, miszerint a tudatelméleti teljesítmény romlik az életkor előrehaladtával (Maylor és mtsai, 2002; Duval és mtsai, 2010), illetve hogy specifikusan a Faux Pas Felismerése Teszten elért teljesítmény is alacsonyabb színvonalú időskorban (Wang és $\mathrm{Su}$, 2006). A tudatelméleti teljesítmény kognitív funkcióktól való függetlenségét (Moran, 2013 időskorra vonatkozó megállapításai) vagy kapcsolatát a második vizsgálatunk eredményei támaszthatják alá.

A Faces Teszttel mért affektív tudatelmélet tekintetében a vizsgálatban részt vevő 5-11 éves korú mintában szignifikáns különbségeket találtunk az 5 életkori csoportban. Az alapérzelmek tulajdonítása tekintetében kapott szignifikáns életkori hatás kapcsán nem vonhatunk le megfelelő következtetéseket az életkori különbségekre nézve. Ennek oka, hogy plafonhatás mutatható ki a gyerekek teljesítményében, mivel még a legfiatalabb életkori csoport is $80 \%$ fölött teljesített az alapérzelmek felismerésében, azaz feltehetően az alapérzelmek képről történő tulajdonítása már 5 éves kor előtt kialakul (1. Westby és Robinson, 2014). A komplex érzelmek tulajdonítása tekintetében a 11 éves gyerekek teljesítménye a legmagasabb, míg az 5-6 éves gyerekek teljesítménye a legalacsonyabb a mintánkban, vagyis a teljesítménynövekedés az életkorral párhuzamban halad. A másik almintánkban, a 11-75 éves korosztályban azonban az életkori különbségek nem mutathatók ki, ennek oka lehet, hogy mind az alap, mind a komplex érzelmek tekintetében magas színvonalon teljesítettek az általunk vizsgált személyek, azaz feltehetően a plafonhatás lehet oka a különbségek hiányának. Vélhetően egy érzékenyebb, jobban differenciáló mérőeszközzel az életkor különbségek már regisztrálhatók (1. Szemekből Olvasás Teszt alkalmazása esetén, pl. Duval és mtsai, 2010; Gunther-Moor és mtsai, 2011).

A tudatelméleti tesztek (Faux Pas Felismerése és Faces Teszt) közötti kapcsolatok vizsgálatában gyenge vagy mérsékelt összefüggéseket kaptunk mind a két almintában. Az 511 éves almintánkban a Faux Pas Felismerése Teszt hamis vélekedés megértésére vonatkozó kérdései nem korrelálnak a Faces Teszt eredményeivel, azonban az összpontszám a Faces Teszt minden elemével, az elszólások detektálása és a történetek megértése pedig az alapérzelmek és a komplex érzelmek felismerésével pozitívan korrelál. A 11-75 éves almintánkban a Faux Pas Felismerése Teszt elszólásokat tartalmazó történetei, illetve a kognitív és affektív komponense a Faces Teszt alapérzelmek felismerésével nem jeleznek 
kapcsolatot, ugyanakkor a komplex érzelmek felismerésével szignifikáns, gyenge kapcsolatban állnak. A faux pas-k kognitív komponense, azaz az elszólások mögötti hamis vélekedések megértése a felnőtt tesztváltozattal mért almintában már korrelál a Faces összpontszámmal. Ennek hátterében elsősorban az állhat, hogy a gyermek tesztváltozattal ellentétben a felnőtt változat tartalmaz affektív mentálisállapot-tulajdonításra vonatkozó kérdést, azaz a Faux Pas összteljesítményben már szerepelnek a komplex érzelmek is, ezek vélekedésen alapuló érzelmek, azaz gondolatok, vélekedések tulajdonítása is szükséges az adott komplex érzelem felismeréséhez. A Faux Pas Felismerése Teszt felnőtt változatában az elszólást nem tartalmazó kontrolltörténetek egyik tudatelméleti teszttel sem mutatnak korrelációt, a tudatelméleti feladatok és a kontrolltörténetek közötti összefüggés hiánya tehát arra utal, hogy valóban eltérő területeket vesznek igénybe e feladatok megoldásai.

Összességében az eredmények arra utalnak, hogy az 5-11 éves korosztályban, aki képes érzékelni egy társas helyzetben elkövetett sértést, képes lehet annak a negatív érzelmi következményeit is azonosítani. A történetek megértésével kapcsolatos összefüggések arra utalnak, hogy a komplex érzelmek feldolgozásához is szükséges bizonyos megértési képesség, vagyis az, hogy az adott komplex érzelmet kifejező szó valójában milyen érzelmet takar. Ugyanakkor az elszólások mögötti hamis vélekedések megértése és az affektív tudatelméleti komponens nem mutat kapcsolatot, vagyis feltehetően a hamis vélekedések megértése független a tudatelmélet affektív komponensétől, a faux pas-k megértésének kognitív komponensét takarja a Faux Pas Felismerése Teszt gyermek változatában. Érdekes eredmény tehát, hogy az általunk vizsgált 5-11 éves korú mintához képest a felnőtt tesztváltozat esetében kevesebb és alacsonyabb korreláció mutatkozott a tesztek között. Ennek oka lehet az is, hogy kevésbé igényli például a kognitív erőfeszítést, a vélekedések, szándékok tulajdonítását az affektív tudatelméletet mérő teszt megoldása. A tesztek között meglévő kapcsolatok azt jelzik, hogy a faux pas-k felismerése és megértésének képessége nem teljesen független az affektív tudatelmélettől, a két, általunk alkalmazott eljárás nem egymástól független területeket mér az explicit tudatelmélet vizsgálatában. Míg a Faces Teszt esetében azt mondhatjuk, hogy a tudatelmélet affektív komponensét méri, a faux pas kapcsán megállapítható, hogy definíció szerint is komplex tudatelméleti képességet mér, vagyis az elszólások teljes körű megértéséhez szükséges a kognitív és az affektív tudatelméleti komponens egyidejü mozgósítása is (Stone és mtsai, 2003; Harari és mtsai, 2010; Poletti és mtsai, 2011). 
Eredményeink szerint a faux pas történetekkel mért explicit tudatelméleti teljesítmény 7 éves korban megjelenik, azonban nem változik radikálisan a 11 éves életkorig. A felnőtt tesztváltozat azonban jobban differenciál az életkori csoportok között a 11-75 éves korú almintában, míg 11-12 éves kor között teljesítményemelkedés, addig a legidősebb életkorban, a 60-75 évesek korosztályában szignifikáns teljesítményromlás következik be a tudatelméleti teljesítményben, megerősítve a külföldi kutatások eredményeit (Wang és $S u, 2006$ ). Az affektív tudatelméleti komponenst mérö Faces Teszt alacsonyabb életkori övezetekben jobban differenciál, míg a serdülőkortól már nem jelez életkori főhatást, utóbbinak elsősorban módszertani okai lehetnek, hiszen plafonhatás érvényesül. Az alapérzelmek felismerése kapcsán mind a 10 életkori csoportban magas szintű a teljesítmény, azaz feltehetően ez a képesség a szakirodalmi adatokkal összhangban már korábban kialakul (Westby és Robinson, 2014). Az általunk alkalmazott tudatelméleti tesztek közötti kapcsolatok arra utalnak, hogy nem egymástól független domaineket mérnek, azaz jelen vizsgálat szerint a komplex explicit tudatelméleti müködésben szerepet játszik a kognitív és az affektív tudatelméleti komponens is a tipikus müködésben.

\subsection{A tudatelméleti képesség és a munkamemória kapacitás közötti összefüggések}

A második vizsgálat során arra kerestük a választ, hogy a munkamemória-kapacitás és a tudatelméleti teljesítmény között milyen összefüggések tárhatók fel, hiszen kevés kutatás számol be az iskoláskorú gyerekek tudatelméletének és munkamemória kapacitásának kapcsolatáról, továbbá konkrétan a komplex tudatelméleti müködést mérő Faux Pas Felismerése Teszt, a Faces Tesztek és a munkamemória kapacitás kapcsolatáról. Az elemzéseket az előző vizsgálathoz hasonlóan két almintában, a Faux Pas Felismerése Teszt gyermek (7-11 évesek) és a felnőtt (11-75 évesek) tesztváltozatával mért almintában végeztük, mindkét almintában az életkor hatását kiszürve végeztük az elemzéseket.

A Faux Pas Felismerése Teszt tekintetében a 7-11 évesek almintájában elsősorban a komplex munkamemória kapacitása, azaz a Hallási Mondatterjedelem Teszttel mért teljesítmény áll összefüggésben a faux pas-k felismerésének képességével. Azaz minél jobb komplex munkamemória kapacitással rendelkezik a személy, annál jobb színvonalú 
teljesítményt nyújt a tudatelméleti teszten és azok összetevőin. A történetek megértésére vonatkozó kérdésekkel mindhárom emlékezeti teszt pozitívan korrelál, azaz az elszólásokat tartalmazó történetek megértésében fontos a munkamemória kapacitás szerepe. Az elszólások felismerésében és a hamis vélekedés megértésében elsősorban a komplex munkamemória kapacitása mutat magasabb összefüggést. A 11-75 évesek almintájában mutatkozó eredmények arra utalnak, hogy a Faux Pas Felismerése Teszt a verbális munkamemóriát mérő Számterjedelem Teszttel, illetve a munkamemóriát mérő Fordított Számterjedelem Teszttel mutat pozitív összefüggéseket. A korrelációs együtthatók gyengék illetve mérsékeltek, azonban az megállapítható, hogy mivel a felnőtt tesztváltozatban a kontrolltörténetek egyik emlékezeti teszttel sem korrelálnak, így a tudatelméleti feladatok esetén kimutatott összefüggések nem az általános szövegfeldolgozásból, illetve történetmegértésből adódnak, hanem specifikusan a tudatelméleti müködést megkívánó történetek sikeresebb megoldása kívánja meg a magasabb színvonalú munkamemória kapacitást.

A Faces Teszt tekintetében a 7-11 évesek almintájában a Faces Teszt minden eleme (összpontszám, alapérzelmek és komplex érzelmek tulajdonítása) megoldásának sikeressége a munkamemória kapacitásával összefügg. Az alapérzelmek felismerése kapcsán megjelenő munkamemória kapacitással való korreláció oka feltheteően elsősorban módszertani, hiszen az alapérzelmek felismerése univerzális, azonban a feladat jellegéből adódóan (fénykép alatt két érzelmet leíró szó közül szükséges kiválasztani a helyeset) szükséges lehet a verbális munkamemória, illetve a komplex munkamemória mozgósítása. Emellett a komplex érzelmek esetében pedig a feladat jellege mellett fontos tényező lehet az is, hogy a komplex érzelmek felismeréséhez vélekedések, szándékok tulajdonítása is szükséges, így ezek a tényezők is megkívánhatják a munkamemória mozgósítását a vizsgált, 7-11 éves korú mintában. A 11-75 éves életkorban a Faces Teszten elért összteljesítmény és a munkamemória kapacitását mérő eljárások között szignifikáns együttjárás van, ez az összefüggés az alapérzelmek és a komplex érzelmek felismerése esetében is megjelenik. Az affektív tudatelméleti teljesítménynek az emlékezeti tesztek közül a komplex munkamemóriát mérő Hallási Mondatterjedelem Teszttel a legerősebbek az összefüggései, azaz a jobb munkamemória kapacitás magasabb affektív tudatelméleti teljesítménnyel jár együtt a vizsgált 11-75 éves mintában. 
Az életkor kontrollálását követően a komplex (kognitív és affektív) explicit tudatelméleti müködés, illetve az affektív explicit tudatelméleti teljesítmény és a munkamemória egyes komponensei között összefüggések mutathatók ki. Az összefüggések gyengék vagy mérsékeltek ugyan, azonban mindegyik pozitív irányú, azaz a jobb emlékezeti kapacitás jobb tudatelméleti müködéssel jár együtt.

Vizsgálatunk alapján tehát megállapítható, hogy az általunk alkalmazott explicit tudatelméleti mérőeljárások munkamemória kapacitással összefüggésben mérik a tudatelméleti teljesítményt. Ez fontos módszertani kérdéseket vet fel a későbbi kutatásokra nézve, mindenesetre jelen vizsgálatban olyan tudatelméleti komponenseket mértünk, melyeknek a sikeres megoldása a kognitív kapacitást igénybe veszi (Frith és Frith, 2008; Apperly, 2011). Eredményeink tükrében tehát nem az a fó kérdés, hogy az affektív vagy a kognitív tudatelméleti komponensek mérése igényel-e, vagy milyen mértékben igényli a kognitív erőforrásokat, hiszen vizsgálatainkból kiderül, hogy mindkét komponens sikeres müködésében szerepet játszik a munkamemória kapacitása. Sokkal inkább az a kérdés merül fel, hogy ha a döntően verbális alapú tesztek megoldásához kis mértékben ugyan, de szükséges a munkamemória müködése, akkor mennyire valószínü, hogy képesek ezek a tesztek jól megragadni a tudatelméleti teljesítményt. Illetve az általános munkamemória tesztek sajátossága, hogy verbális vagy perceptuális ingerekkel méri a munkamemóriát, azonban nyitott kérdés, hogy vajon a szociális ingereket alkalmazó munkamemória tesztek (social working memory, Meyer és Lieberman, 2012) milyen irányú kapcsolatban állhatnak a tudatelméleti teljesítménnyel. A későbbiekben természetesen más vizsgálóeljárások alkalmazásával differenciálható, jobban részletezhető ez az eredmény. 


\subsection{A tudatelméleti képesség és a társas pozíció közötti összefüggések}

Feltételezéseink szerint a tudatelmélet és társas viselkedés között mutatható ki kapcsolat az általunk vizsgált 8-14 éves iskoláskorú diákok körében. A gyerekek társas viselkedésének mérésére a korábbi kutatásokban (Banerjee és Watling, 2005; Banerjee, Watling és Caputi, 2011) is alkalmazott egyszerü választásos szociometriai módszert alkalmaztuk, majd három módszer segítségével elemeztük. A tudatelméleti képesség mérését a Faux Pas Felismerése Teszt gyermek (8-10 éves korban) és felnőtt (12-14 éves korban) változatával, illetve a Faces Teszttel mértük, továbbá a munkamemória kapacitást is vizsgáltuk a Számlálási Terjedelem Teszt alkalmazásával.

Az elsőként alkalmazott egyszerü szociometriai besorolás esetén a népszerü és az elutasított gyermekek teljesítményét hasonlítottuk össze. Az eredmények alapján megállapítható, hogy egyik tudatelméleti teszt eredményei sem mutatnak különbségeket sem a 8-10, sem pedig a 12-14 éves korosztályban, azaz nem differenciálnak a szociometriai pozíció függvényében. A munkamemória kapacitása egyedül a 8-10 éves korosztályban mutat különbségeket a népszerü és az elutasított gyermekek között. Míg a vizsgálatban szereplő alsó tagozatosok esetében a munkamemória fontos differenciáló tényező, addig felső tagozatban ez már nem jelentős a gyerekek által megítélt szociometriai pozíció tekintetében, azaz a népszerüség és a kognitív funkciók közötti összefüggés nem jelenik meg az idősebb korosztályban. Az egyszerü csoportosítás kapcsán felmerül, hogy a pozitív és a negatív választások számát nem vesszük figyelembe a csoportosítás során, pusztán a pozitív és negatív választások egymáshoz viszonyított számát, vagyis így azok a gyerekek is népszerünek számítanak, akik kevés pozitív választással rendelkeznek, és azok is, akik viszont jóval több pozitív választást kaptak. Ez a csoportosítás nem képes tehát megfelelően kezelni a népszerüség és az elutasítottság mértékét.

A második, már négy szempontot figyelembe vevő csoportosítás során négy szociometriai csoportot vontunk be az elemzésbe, a népszerü, elutasított, elhanyagolt és semleges szociometriai csoportba sorolt gyerekeket Banerjee és Watling (2005) módszere alapján. Egyik tudatelméleti teszten sincs különbség a szociometriai pozíció függvényében, 
egyik életkori csoportban sem. Vagyis ebben az értékelési rendszerben sem mutatható ki az az előzetes feltételezés, miszerint a népszerü gyerekek jobb tudatelmélettel jellemezhetők. A munkamemória ebben a csoportosításban is fontos differenciáló tényező a, hiszen a népszerü és semleges szociometriai pozíciójú gyerekeknek magasabb a munkamemória kapacitása, azonban ez az összefüggés csak az általunk vizsgált 8-10 éves, alsó tagozatos korosztályban mutatható ki. Vagyis ebben a standardizált változókat alkalmazó, négy szempontot figyelembe vevő csoportosításban is elsősorban a munkamemória kapacitása differenciál a szociometriai csoportok között, mégpedig alsó tagozatos korosztályban. Felső tagozatban a kognitív funkciók szerepe vizsgálatunk eredményei szerint nem jelentős, azonban a tudatelméleti képesség sem tud a szociometriai pozíció magyarázatául szolgálni.

A vizsgálatban alkalmazott harmadik elemzési módszer esetében korrelációs elemzéseket végeztünk a tudatelméleti teszten elért teljesítmény és a társak közötti elfogadottság és elutasítottság változói között, illetve a tudatelméleti teljesítmény és a társas befolyás és a társas preferencia változói között (Banerjee és Watling, 2005; Banerjee, Watling és Caputi, 2011). Ebben az elemzésben mérsékelt összefüggéseket tártunk fel, és ezek az összefüggések is többnyire a magasabb életkori csoportban jelentek meg, a 12-14 évesek között. A 8-10 éves gyerekek almintájában az elszólások detektálása és társas preferencia változó között gyenge kapcsolat mutatható ki. Míg a 12-14 éves korosztályban kapott eredményeink szerint a társas befolyás (a gyermekre adott összes választások száma) változó korrelál az affektív tudatelméleti teszten elért eredménnyel, illetve a standardizált pozitív választások (a társak általi elfogadottság mértéke) is korrelálnak az affektív tudatelméleti teszten elért teljesítménnyel, a korrelációk pozitív irányúak. Azaz a több összesített választást kapó gyerekek, illetve a magasabb elfogadottságnak örvendő gyerekek magasabb szintü affektív tudatelmélettel jellemezhetők a vizsgált mintában.

Összességében a kapott eredmények megerősítik az eddig is vizsgált, a tudatelmélet és a társas viselkedés közötti ellentmondásos, illetve gyenge összefüggéseket. Eredményeink szerint a szociometriai pozíció szerinti csoportosításban nincs szignifikáns eltérés abban az irányban, hogy a népszerübb gyerekek jobb, illetve az elutasított gyerekek alacsonyabb színvonalú tudatelméleti működéssel jellemezhetők egyik korosztályban sem. A társas befolyás, illetve a pozitív választások értékei esetében szignifikáns korrelációk mutathatók ki az affektív tudatelméleti teljesítménnyel a 12-14 éves korosztályban. A korábbi, általunk alapul vett vizsgálatokban kimutatott összefüggések is az idősebb korosztályban jelentek meg 
(5-6 éveseknél nem, míg a 8-9 éveseknél kimutathatók korrelációs együtthatók, Banerjee és Watling, 2005). Saját vizsgálatunkban a 8-10 évesek esetében csak tendenciajellegűek és gyengék az összefüggések. A 12-14 éves gyerekek esetében a magasabb szintű társak általi elfogadottság, és a társakra történő befolyás magasabb színvonalú affektív tudatelméleti teljesítménnyel jár együtt, vagyis azok a 12-14 éves gyerekek, akiknek a társas müködése a szociometriai módszer alapján magasabb színvonalú, magasabb affektív tudatelméleti képességgel jellemezhetők. Az összefüggések azonban csak a Faces Teszttel kapcsolatban jelentek meg, míg a Banerjee és Watling (2005), illetve a Banerjee, Watling és Caputi (2011) vizsgálataiban is alkalmazott faux pas-k megértésével, ellentmondva az ő eredményeiknek, mi nem találtunk összefüggéseket. Ennek egyrészt a tesztben keresendő módszertani oka lehet, miszerint ők egy módosított faux pas tesztet alkalmaztak, míg mi az eredeti változattal mértük a faux pas-k megértését. Specifikusan az affektív tudatelmélet vizsgálatára az általunk áttekintett kutatások nem tértek ki, vagyis eredményeink mindenképpen figyelemre méltók a társas pozíció és a tudatelmélet vizsgálatának kapcsolatában. Természetesen az általunk végzett elemzések összefüggés-vizsgálatok, így ok-okozati kapcsolatok nem feltárhatók ez alapján, azaz nem mondhatjuk, hogy amiatt jobb az affektív tudatelmélet, mert jobban elfogadják őket a társaik, és azt sem jelenthetjük ki, hogy amiatt fogadják el a gyermeket jobban a társak, mert magasabb szintű az affektív tudatelmélete.

A szociometriai pozíció tekintetében jelen vizsgálatban tehát nem mutathatók ki eltérések a tudatelméleti müködésben, a munkamemória kapacitás tekintetében viszont 8-10 évesek körében igen. Mindez alapján feltételezhetjük, hogy a szociometriai pozícióban az alsó tagozatos gyermekek körében inkább a kognitív funkciók a meghatározók jelen mintában, míg felső tagozatban már nem, ugyanakkor a tudatelméleti képesség sem lesz meghatározó a szociometriai pozíció tekintetében. Feltehetően a szociometriai pozícióban, illetve a pozitív és a negatív választásokban más meghatározó tényezők is közrejátszanak, így érdemes lehet a további vizsgálatokba más meghatározókat is bevonni. 


\subsection{Kutatásunk jelentősége, korlátai, további kutatási lehetőségek és fejlesztési irányvonalak}

A disszertációban bemutatott vizsgálatsorozat jelentősége egy magyar nyelvü tudatelméleti mérőeljárás bemutatása és kipróbálása, mely gyermekkorban, az iskolás korosztályban, illetve serdülő- és felnőttkorban is alkalmazható, az életkori különbségek saját vizsgálatunkban is megjelennek, elsősorban a felnőtt tesztváltozat alkalmazásával. Sajátossága a Faux Pas Felismerése Tesztnek a gyermek és a felnőtt tesztváltozat, ugyanakkor az életkori változatok egységesítése, azaz a későbbiekben egy olyan mérőeszköz kialakítása, amely egységesen alkalmazható a tudatelmélet mérésére, az életkori sajátosságaihoz igazodva. Saját vizsgálati tapasztalataink azt mutatják, hogy a felnőtt tesztváltozat jobban differenciál az életkori csoportok között, illetve mivel több kérdést tartalmaz az egyes történeteket követően, így több szempont mérésére alkalmas (pl. az elszólást követő negatív érzelmek tulajdonítására vonatkozó kérdés a gyermek változatban nem, míg a felnőtt változatban már szerepel). Későbbi vizsgálatokban felmerülhet annak kérdése, hogy a felnőtt tesztváltozat mintájára módosítsuk a gyermekek esetén alkalmazható változatot, illetve egységesített mérőeljárást alalkítsunk ki például az iskolás korosztály mérésére.

Kutatásunkban a munkamemória kapacitás és a tudatelmélet közötti összefüggéseket vizsgáltuk, ez magyar mintán hiánypótló, ugyanakkor a későbbiekben szükséges más kognitív funkciókkal való kapcsolatot is vizsgálni. A korábbi külföldi kutatásokban a végrehajtó funkciókkal, például a gátlófunkciókkal találtak kapcsolatot a tudatelmélettel (pl. Carlson és Moses, 2001; Razza és Blair, 2009; Müller és mtsai, 2012), későbbi vizsgálatokban a munkamemória kapacitás mellett tervezzük bevonni a végrehajtó funkciók vizsgálatát is. Továbbá a kettős terheléles vizsgálati módszert alkalmazva egyértelmúbb képet kaphatunk az explicit tudatelméleti müködésben a munkamemória szerepéröl (1. pl. McKinnon és Moscovith, 2007), mindezt széles életkori spektrumon lehet érdemes vizsgálni a továbbiakban. További vizsgálati lehetőség, hogy a szociális munkamemória mérésével kiegészítve térképezzük fel, hogy az általános munkamemória kapacitás mellett a szociális munkamemória milyen mértékben függ össze a tudatelméleti teljesítménnyel (Meyer és Lieberman, 2012).

Jelen disszertációban a társas pozícióval összefüggésben is vizsgáltuk a tudatelméleti müködést, mellyel kapcsolatban mérsékelt összefüggéseket tudtunk kimutatni. Saját 
vizsgálatunkban a külföldi vizsgálatokat követve (Banerjee és Watling, 2005; Banerjee, Watling és Caputi, 2011) a szociometriai módszert alkalmaztuk a társas viselkedés mérésére. Érdekes eredmény ugyanakkor, hogy a munkamemória kapacitása elsősorban a 8-10 éves korosztályban differenciált a szociometriai pozíció függvényében. Azaz feltehetően a szociometriai pozíció, a gyerekek társak közötti népszerűsége vagy elutasítottsága mögött számos egyéb tényező is meghatározó lehet (pl. SES, szorongás, pedagógiai helyzetből adódó jellemzők). Emiatt egyrészt a további kutatásokban érdemes lehet többszempontú szociometriai módszert alkalmazni, illetve akár megfigyeléssel kiegészíteni ezeket a kutatásokat. Másrészt azonban a korábbi kutatásokban is igen változatos módszerrel mérték a gyerekek szociális kompetenciáját (pl. Liddle és Nettle, 2006; Newton, Reddy és Bull, 2000), érdemes lehet feltérképezni a szociális kompetencia azon összetevőit, amelyek az iskolai társas helyzetek kezelésében kulcsfontosságúak lehetnek, majd összevetni a tudatelmélet különböző komponenseivel. Az egyik ilyen alternatíva lehet a szociálisprobléma-megoldás vizsgálata a tudatelmélettel összefüggésben. A szociálisprobléma-megoldás (Chang és mtsai, 2004; Kasik és Gál, 2014b) és a tudatelmélet kapcsolatának feltárására óvodáskorúak körében végeztünk vizsgálatokat (Gál és Kasik, 2015a; Gál és Kasik, 2015b), eredményeink szerint az összefüggések differenciáltabban jelennek meg, mint a jelen disszertációban bemutatott szociometriai elemzési módszer alkalmazásával, ennek iskoláskorra való kiterjesztése egy következő kutatási célunk. Továbbá a gyermekek egymás közötti értékelése illetve önbeszámolós módszerek alkalmazása mellett szükséges lehet egyidejüleg külső értékelők bevonása is a vizsgálatokba, ahogyan ezt a szociálisprobléma-megoldást feltáró vizsgálatokban is alkalmazzuk (pl. Kasik és Gál, 2014a). A társas alkalmazkodással kapcsolatos kutatások esetében is felmerült az a kritika (pl. Astington, 2003; Banerjee, Watling és Caputi, 2011), miszerint a tudatelméletet mérő tesztek nem feltétlenül kellően realisztikusak ahhoz, hogy a valós társas helyzetek összetettségét képesek legyenek megragadni, a faux pas-k megértésével kapcsolatos történetek talán a realitáshoz legközelebb állnak a tudatelméleti tesztek közül. Azonban saját vizsgálataink alapján látható, hogy a munkamemória kapacitás különböző mértékben ugyan, de együttjár a faux pas-k megértésének képességével, így megfontolandó, hogy az explicit, kognitív funkciókat igénybe vevő tudatelméleti vizsgálati módszerek mellett alkalmazzunk olyan implicit kutatási módszereket, amelyekkel akár megfelelőbben bejósolható a gyerekek szociális kompetenciája is. Ez amiatt is lényeges, hiszen a szociális készségek elsajátításában az implicit kogníciónak, 
különösen az implicit tanulásnak is fontos szerepe van (Lieberman, 2000). Az explicit tudatelméleti módszerek alkalmazása esetén felmerülhet például, hogy a válaszadásig eltelt időt, a személy reakcióidejét mérjük, vagy például a fényképeket alkalmazó tesztek esetében a viselkedéses adat, vagyis a teljesítmény mellett mérjük a tekintetirányt is, hasonlóan a csecsemőkkel kapcsolatos vizsgálatokban is alkalmazott stratégiákhoz. Egy ilyen explicitimplicit kutatási paradigma megalkotása hiánypótló lehet az iskolás korosztály tudatelméletének mérésére, és a szociális kompetenciával való összefüggéseinek feltárására.

A társas hatékonysággal kapcsolatos tudatelméleti kutatások az iskolai alkalmazkodás elősegítése kapcsán különösen lényegesek, például a szociális készségfejlesztő foglalkozásokba beépítve a tudatelméletet fejlesztő módszereket. A klinikai kutatásokban az úgynevezett mentalizációs alapú terápiákat már sikeresen alkalmazzák például a borderline személyiségzavar kezelésében (pl. Bateman és Fonagy, 2004; Allen, Fonagy és Bateman, 2011), továbbá evészavarok kezelésében is alkalmazzák a tudatelmélet fejlesztését is magában foglaló eljárásokat (pl. Tchanturia és mtsai, 2007; Money és mtsai, 2011). A tipikus fejlődés kapcsán a klinikai gyakorlatban is alkalmazott technikák hatékonyságát érdemes lehet felmérni. Az intervenciós módszerekben ajánlott mentalizációt elősegítő technikák közül például a „Tükröző folyamatot alakítunk ki, és abban kontingensen válaszolunk, jelöljük az érzelmeket...” vagy a „...biztatjuk, hogy több szempontból vizsgáljon meg egy interakciót vagy saját élményt" (Allen, Fonagy és Bateman, 2011, 158. old.) a tipikus müködésben, az életkori sajátosságoknak megfelelően minden bizonnyal alkalmazhatók akár a specifikusan szociális készséget fejlesztő módszerekben, bullying prevencióban, vagy akár a tartalomba ágyazott fejlesztésekben. A tartalomba ágyazott fejlesztések kapcsán Lieberman (2012) jegyezte meg, hogy például a történelem órák vagy az angol órák tartalmuknál fogva alkalmasak lehetnek a „társas agy” fejlesztésére, a mentalizációs hálózat aktivizálására, továbbá olyan oktatási módszerek alkalmazását ajánlja (pl. társak tutorálása a tanórákon), amelyek feltehetően szintén hozzájárulnak a mentalizációs hálózat mozgósításához.

A tudatelméleti kutatások heterogenitása tehát lehetővé teszi azt is, hogy specifikusan az iskolás korosztály életkori és egyéni különbségeit, kognitív funkciókkal és a társas hatékonysággal való kapcsolatait feltárva a későbbiekben olyan módszereket ajánlhassunk, ami a tanórákon vagy tanórán kívüli helyzetekben tudatosan alkalmazva segíthetik a gyerekek iskolai alkalmazkodását. 


\section{KöSZÖNETNYILVÁNÍTÁS}

A disszertáció elkészítése kapcsán szeretném megköszönni témavezetőm, Dr. Németh Dezső támogatását, biztatását. Köszönöm Dr. Janacsek Karolina együttműködését, a statisztikai elemzésekben vállalt körültekintő segítségét és javaslatait.

Köszönöm Dr. Egyed Katalin motiválását, aki egyetemi éveim alatt megismertette velem a tudatelmélet témáját, szakdolgozati kutatásom során folyamatos biztatásával segítette a munkámat.

A doktori tanulmányok során Dr. Csapó Benő kutatói munkával kapcsolatos elvárásai motiváltak, köszönettel tartozom, hogy lehetővé tette számomra a Neveléstudományi Intézet és a Doktori Iskola infrastruktúrájának használatát.

Köszönettel tartozom Dr. Pukánszky Béla Professzor Úrnak, aki a Gyógypedagógus-képző Intézet vezetőjeként támogatott a $\mathrm{PhD}$ fokozat megszerzésében. Köszönet illeti továbbá Ujvári Orsolyát, aki rugalmasságával sok terhet vett le a vállamról a disszertáció elkészítésének folyamatában.

Köszönet illeti a Szegedi Tudományegyetem pszichológia és gyógypedagógia szakos hallgatóit, akik az adatfelvételtben nélkülözhetetlen munkát végeztek. Köszönettel tartozom azoknak az intézményeknek, pedagógusoknak, és természetesen a vizsgálatban részt vevő személyeknek, akik együttmüködése nélkül nem valósulhattak volna meg vizsgálataink.

Hálás vagyok a Szüleimnek, az általuk képviselt értékek és elvárások segítettek abban, hogy a doktori képzésemet megkezdjem és zavartalanul végezhessem. Köszönöm Férjemnek, Kristófnak a türelmét, amivel lehetővé tette, hogy nyugodtan dolgozhassak. Köszönet illeti Molnár Katalint, akinek folyamatos biztatása sokat jelentett a doktori képzés során. Köszönöm Dr. Kasik Lászlónak a barátságát, nem szűnő motiválását és a sok korrektúráját a munkáimban, hogy azok minél jobb színvonalúak legyenek. Köszönöm nekik, hogy mindig mellettem álltak, biztatásukkal és szeretetükkel erőt adtak. 


\section{TÁBLÁZATOK JEGYZÉKE}

1. táblázat: Az áttekintett tudatelméleti komponensek összefoglalása az egyes szerzők szerint. 15

2. táblázat: A tudatelméleti müködésben kimutatható agyi területek összefoglaló táblázata Abu-Akel és Shamay-Tsoory (2011) alapján (2972. o)

3. táblázat: A széles körben alkalmazott tudatelméleti tesztek összefoglaló táblázata.

4. táblázat: A tudatelméleti komponensek megjelenése tipikus fejlődésmenetü gyermekeknél, a tudatelmélet szintek és azokhoz tartozó készségek Westby és Robinson (2014, 366-368. o.) alapján

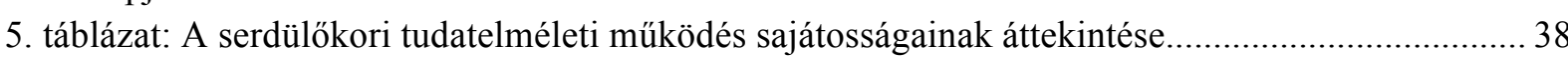

6. táblázat. Az életkor átlaga és szórása az egyes életkori övezetekben ........................................... 79

7. táblázat: A szociometriai csoportok kialakításának módja Banerjee és Watling (2005) alapján ....... 89

8. táblázat: Átlageredmények a tudatelméleti teszteken az 5-11 éves korosztályban............................ 95

9. táblázat: A Faux Pas Felismerése Teszt és a Faces Teszt közötti korrelációs együtthatók az 5-11

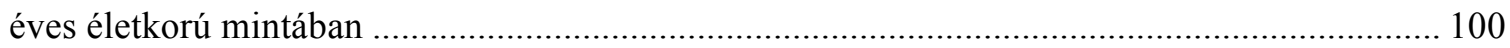

10. táblázat: Átlageredmények a tudatelméleti teszteken az 11-75 éves korosztályban....................... 106

11. táblázat: A Faux Pas Felismerése Teszt és a Faces Teszt közötti korrelációs együtthatók az 11-75 éves életkorú mintában

12. táblázat: Átlageredmények a tudatelméleti és munkamemória teszteken a 7-11 éves életkorú mintában.

13. táblázat: A Faux Pas Felismerése Teszt és a munkamemória tesztek közötti parciális korrelációs együtthatók az 7 -11 éves életkorú mintában

14. táblázat: A Faces Teszt és a munkamemória tesztek közötti korrelációs együtthatók az 7-11 éves életkorú mintában

15. táblázat: A tudatelméleti és munkamemória teszteken elért átlageredmények a 11-75 éves életkorú mintában.

16. táblázat. A Faux Pas Felismerése Teszt és a munkamemória tesztek közötti korrelációs együtthatók az 11-75 éves életkorú mintában.

17. táblázat. A Faces Teszt és a munkamemória tesztek közötti korrelációs együtthatók az 7-11 éves életkorú mintában

18. táblázat. Az egyszerủ szociometriai csoportosítással kapott pozíciók eloszlása (fö) ..................... 120

19. táblázat. A szociometriai pozíciók eloszlása a mintában (fô) .................................................. 121

20. táblázat a tudatelméleti képesség és a munkamemória kapacitás eltérései a szociometriai pozíció függvényében a 8-10 éves korosztályban

21. táblázat a tudatelméleti képesség és a munkamemória kapacitás eltérései a szociometriai pozíció függvényében a 12-14 éves korosztályban

22. táblázat. A társas preferencia/befolyás, a standardizált pozitív/negatív választások és a tudatelméleti képesség közötti korrelációs együtthatók 


\section{ÁBRÁK JEGYZÉKE}

1. ábra: A kognitív és az affektív tudatelmélet, valamint az empátia összetevőinek kapcsolata ShamayTsoory és munkatársai (2010) nyomán (669. o.)

2. ábra: Az affektív és a kognitív tudatelméleti feldolgozáshoz kapcsolódó agyi területek $A b u$-Akel és Shamay-Tsoory (2011) által kialakított ábrán 2974. o....

3. ábra: A tudatelmélet fejlődésének moduláris rendszere Baron-Cohen (1997. 32. o.) nyomán .46

4.ábra: A Faux Pas Felismerése Teszt gyermek tesztváltozatán nyújtott teljesítmény életkori különbségei 5 éves kortól 11 éves korig. 93

5.ábra: A Faces Teszt komplex érzelmek felismerésének átlagértékei az egyes életkori csoportokban 97

6. ábra: A Faces Teszt összpontszámának átlagértékei az egyes életkori csoportokban 98

7. ábra: A Faux Pas Felismerése Teszt felnőtt változatán nyújtott teljesítmény életkori különbségei 11 éves kortól 75 éves korig...... 102

8. ábra: A Faux Pas Felismerése Teszt hamis vélekedés megértésére vonatkozó kérdésén nyújtott teljesítmény életkori különbségei 11 éves kortól 75 éves korig

9. ábra: A Faux Pas Felismerése Teszt negatív érzelmi következmények megértésére vonatkozó kérdésén nyújtott teljesítmény életkori különbségei 11 éves kortól 75 éves korig. 


\section{IRODALOM}

Abu-Akel, A. és Shamay-Tsoory, S. (2011): Neuroanatomical and neurochemical basis of theory of mind. Neuropsychologia, 49. 2971-2984.

Ahmed, F. S. és Miller, L. S. (2011): Executive Function Mechanisms of Theory of Mind. Journal of Autism and Developmental Disorders, 41. 5. sz. 667-678.

Allen, J. G., Fonagy, P., és Bateman, A. W. (2011): Mentalizáció a klinikai gyakorlatban. Budapest: Oriold és Társai.

Altgassen, M., Vetter, N. C., Phillips, L. H., Akgün, C. és Kliegel, M. (2014): Theory of mind and switching predict prospective memory performance in adolescents. Journal of Experimental Child Psychology, 127. 163-175.

Amodio, D. M. és Frith, C. (2006): Meeting of minds: the medial frontal cortex and social cognition. Nature Reviews Neuroscience, 7. 4. sz. 268-277.

Apperly, I. (2011): Mindreaders: The Cognitive Basis of Theory of Mind. Psychology Press.

Apperly, I. (2013): Can theory of mind grow up? Mindreading in adults, and its implications for the neuroscience and development of mindreading. In. Baron-Cohen, S., Tager-Flusberg, H. és Lombardo, M. V. (szerk): Understanding Other Minds: Perspectives from developmental social neuroscience. Oxford University Press. 72-92.

Apperly, I.A., Samson, D. és Humphreys, G.W. (2009): Studies of adults can inform accounts of theory of mind development. Developmental Psychology, 45. 1. sz. 190-201.

Astington, J. W. (2003): Sometimes Necessary, Never Sufficient. False-Belief Understanding and Social Competence. In: Repacholi, B. és Slaughter, V. (szerk.): Individual differencies in Theory of Mind. Implications for typical and atypical development. New York: Psychology Press. 1440 .

Astington, J. W. és Baird, J. A. (2005): Why language matters for theory of mind. New York: Oxford.

Astington, J., és Jenkins, J.M. (1999): A longitudinal study of the relation between language and theory-of-mind development. Developmental Psychology, 35. 5. sz. 1311-1320.

Banerjee, R. és Watling D (2005): Children's understanding of faux pas: Associations with peer relations. Hellenic Journal of Psychology: Special Issue on Theory of Mind, 2. 27-45.

Banerjee, R., Watling, D. és Caputi, M. (2011): Peer Relations and the Understanding of Faux Pas: Longitudinal Evidence for Bidirectional Associations. Child Development, 82. 6. sz. 1887-1905. 
Baron-Cohen, S., Wheelwright, S., Hill, J., Raste, Y. és Plumb, I. (2001): The Reading the Mind in the Eyes Test revised version: A study with normal adults, and adult with Asperger syndrome or high-functioning autism. Journal of Child Psychology and Psychiatry, 42. 2. sz. 241-251.

Baron-Cohen, S. (1989): The autistic child's theory of mind: a case of specific developmental delay. Journal of Child Psychology and Psychiatry, 33. 1141-1155.

Baron-Cohen, S. (1997): Mindblindness: An essy on autism and theory of mind. MIT Press.

Baron-Cohen, S. (2001): Theory of mind in normal development and autism. Prisme, 34. 174-183.

Baron-Cohen, S., Jolliffe, T., Mortimore, C., és Robertson, M. (1997): Another advanced test of theory of mind: Evidence from very high functioning adults with autism or Asperger Syndrome. Journal of Child Psychology and Psychiatry, 38. 813-822.

Baron-Cohen, S., Leslie, A. M. és Frith, U. (1985): Does the autistic children have a ,theory of mind"? Cognition, 21. 37-46.

Baron-Cohen, S., O’Riordan, M., Stone, V., Jones, R. és Plaisted, K. (1999): A new test of social sensitivity: Detection of faux pas in normal children and children with Asperger syndrome. Journal of Autism and Developmental Disorders, 29. 407-418.

Bartsch, K. és Wellmann, H. M. (1995): Children talk about the mind. Oxford University Press, New York.

Bateman, A. W. és Fonagy, P. (2004): Mentalization-based treatment of BDP. Journal of Personality Disorders, 18. 1. sz. 36-51.

Bernstein, D. M., Thorton, W. L. és Sommerville, J. A. (2011): Theory of mind through the ages: older and middle-ages adults exhibit more errors than do younger adults on a continuous false belief task. Experimental Aging Research, 37. 481-502.

Bíró Szilvia (2002): A naiv pszichológiai „értelmezés” kezdetei: a racionális cselekvés elvének kísérleti vizsgálata csecsemökorban. Budapest: Osiris Kiadó.

Blakemore, S-J. (2008): Development of the social brain during adolescence. The Quarterly Journal of Experimental Psychology, 61. 1. sz. 40-49.

Blakemore, S-J. (2012): Development of the social brain in adolescence. Journal of the Royal Society of Medicine, 105. 111-116.

Bodden, M. E., Mollenhauer, B., Trenkwalder, C., Cabanel, N., Eggert, K. M., Unger, M. M., Oertel, W. H., Kessler, J., Dodel, R. és Kalbe, E. (2010): Affective and cognitive theory of mind in patiens with Parkinson's disease. Parkinsonism and Related Disorders, 16. 466-470.

Brüne, M. és Brüne-Cohrs, U. (2006): Theory of mind - evolution, ontogeny, brain mechanisms and psychopathology. Neuroscience and Biobehavioral Reviews, 30. 437-455 
Caputi, M., Lecce, S., Pagnin, A. és Banerjee, R. (2012): Longitudinal effects of theory of mind on later peer relations: the role of prosocial behavior. Developmental Psychology, 48. 1. sz. 257270.

Carlson S. M. és Moses L. J. (2001): Individual differences in inhibitory control and children's theory of mind. Child Development, 72. 1032-1053.

Carlson, S. M., Mandell, D. J. és Williams, L. (2004): Executive function and theory of mind: stability and prediction from ages 2 to 3. Developmental Psychology, 40. 6. sz. 1105-1122.

Carlson, S. M., Moses L. J. és Breton, C. (2002): How specific is the relation between executive function and theory of mind? Contributions of inhibitory control and working memory. Infant and Child Development, 11.2. sz. 73-92.

Case, R. D., Kurland, M. és Goldberg, J. (1982): Operational efficiency and the growth of short-term memory span. Journal of Experimental Child Psychology, 33. 3. sz. 386-404.

Castelli, I., Baglio, F., Blasi, V., Alberoni, M., Falini, A., Liverta-Sempio, O., Nemni, R. és Marchetti, A. (2010): Effects of aging on mindreading ability through the Eyes: An fMRI study. Neuropsychologia, 48. 2586-2594.

Chang, E. C., D’Zurilla, T. J. és Sanna, L. J. (2004): Social problem solving. Theory, research, and training. American Psychological Association, Washington, DC.

Choi-Kain, L. W. és Gunderson, J. G. (2008): Mentalization: ontogeny, assessment, and application in the treatment of Borderline Personality Disorder. American Journal of Psychiatry, 165. 11271135 .

Clements, W. A. és Perner, J. (1994): Implicit understanding of false beliefs. Cognitive Development, 9. 377-395.

Conway, A. R. A., Kane, M.J., Bunting, M. F., Hambrick, D.Z., Wilhelm, O. és Engle, R. (2005): Working memory span tasks: A methodological review and user's guide. Psychonomic Bulletin and Review, 12. 5. sz. 769-786.

Cutting, A. L. és Dunn, J. (1999): Theory of Mind, Emotion Understanding, Language, and Family Background: Individual Differences and Interrelations. Child Development, 70. 4. sz. 853-865.

Csibra G., Bíró S., Koós O. és Gergely G. (2003): One-year-old infants use teleological representations of actions productively. Cognitive Science, 27. 111-133.

Csibra Gergely és Gergely György (2002): A naiv tudatelmélet az evolúciós lélektan szempontjából. Magyar Tudomány, 47. 1. sz. 56-63.

Dennis, M., Simic, N., Bigler, E. D., Abildskov, T., Agostino, A., Taylor, H. G., Rubin, K., Vannatta, K., Gerhardt, C. A., Stancin, T. és Yeates, K. O. (2013): Cognitive, affective and conative theory of mind (ToM) in children with traumatic brain injury. Developmental Cognitive Neuroscience, 5. 25-39. 
Denny, B. T., Kober, H., Wager, T. D. és Ochsner, K. N. (2012): A meta-analysis of functional neuroimaging studies of self- and other judgments reveals a spatial gradient for mentalizing in medial prefrontal cortex. Journal of Cognitive Neuroscience, 24. 8. sz. 1742-1752.

Dodell-Feder, D., Lincoln, S. H., Coulson, J. P. és Hooker, C. I. (2013): Using fiction to assess mental state understanding: a new task for assessing theory of mind in adults. Plos One, 8. 11. sz. 1-14.

Doherty, M. J. (2009): Theory of Mind: How children undertand others' thoughts and feelings. Psychology Press.

Dumontheil, I., Apperly, I. A. és Blakemore, S.J. (2010): Online use of mental state inferences continues to develop in late adolescence. Developmental Science, 13. 2. sz. 331-338.

Dunn, J., Brown, J., Slomkowski, C., Tesla, C. és Youngblade L. (1991): Young children's understanding of other people's feelings and beliefs: Individual differences and their antecedents. Child Development, 62. 1352-1366.

Dunn, J., Cutting, A.L. és Demetriou, H. (2000): Moral sensibility, understanding others, and children's friendship interactions in the preschool period. British Journal of Developmental Psychology, 18.159-177.

Duval, C., Piolino, P., Bejanin, A., Eustache, F. és Desgranges, B. (2011): Age effects on different components of theory of mind. Consciousness and Cognition, 20. 3. sz. 627-642.

Dvash és Shamay-Tsoory, (2014): Theory of mind and empathy as multidimensional constructs: Neurological foundations. Topics in Language Disorders, 34. 4. sz. 282-295.

Egyed Katalin és Király Ildikó (2008): Mások viselkedésének megértése és az éntudatosság. In: Csépe Valéria, Győri Miklós, Ragó Anett (szerk.): Általános pszichológia 3. Nyelv, tudat, gondolkodás. Budapest, Osiris, 336-356.

Egyed Katalin és Nagy Viktória (2014): Miért fél/örül Piroska? - Vélekedésen alapuló érzelmek magyarázata óvodás- és kisiskoláskorban. Alkalmazott Pszichológia, 14. 2. sz. 29-54.

Egyed, K., Király, I. és Gergely, Gy. (2013): Communicating Shared Knowledge in Infancy. Psychological Science, 24. 7. sz. 1348-1353.

Ferenczi Szilvia (2009): Elmélet-e a „Tudatelmélet”? Gyógypedagógiai Szemle, 37. 2-3. sz. 112-128.

Frith, C. D. és Frith, U. (2008): Implicit and explicit processes in social cognition. Neuron Perspective, 60. 503-510.

Frith, U. és Frith, C. D. (2003): Development and neurophysiology of mentalizing. Philosophical Transactions of the Royal Society of London, Series B, 358. 459-473.

Gál Zita (2015): A tudatelmélet életkori változásainak és szerepének áttekintése óvodáskortól fiatal felnőttkorig. Iskolakultúra, 25. 5-6. sz. 59-73. 
Gál Zita és Kasik László (2015a): Óvodások hamisvélekedés-teszten mért tudatelméleti teljesítményének és problémamegoldásának kapcsolata. XIII. Pedagógiai Értékelési Konferencia, Szeged, 2015. április 23-25.

Gál Zita és Kasik László (2015b): A helyzet- és személyspecifikus problémamegoldás kapcsolata a tudatelméleti működéssel 4-6 éves korban. Magyar Pedagógia, bírálat alatt

Gál Zita, Egyed Katalin, Pászthy Bea és Németh Dezső (2011): Tudatelméleti deficit anorexia nervosában. Psychiatria Hungarica, 26. 1. sz. 12-25.

Gál Zita, Katona Katalin, Janacsek Karolina és Németh Dezső (2014): Tudatelméleti müködés bünelkövetőknél. Pszichológia, 34. 3. sz. 289-310.

Gallagher, H. L. és Frith, C. (2003): Functional imaging of 'Theory of Mind'. Trends in Cognitive Sciences, 7. 77-83.

Gallagher, S. és Hutto, D. D. (2008): Understanding others through primary interaction and narrative practice. In. Zlatev, J., Racine, T. P., Sinha, C. és Itkonen, E. (szerk.): The shared mind: Perspectives on intersubjectivity. Amsterdam: John Benjamins. 17-38.

Gallese, V. és Goldman, A. (1998): Mirror neurons and the simulation theory of mind-reading. Trends in Cognitive Sciences, 2. 12. sz. 493-501.

Gergely György és Csibra Gergely (2005): Teleologikus gondolkodás csecsemőkorban. Az egyévesek naiv racionális cselekvéselmélete. Magyar Tudomány, 50. 11. sz. 1347-1354.

Gergely György, Egyed Katalin és Király Ildikó (2007): A természetes pedagógiáról. Magyar Pszichológiai Szemle, 62. 1. sz. 107-125.

German, T. P. és Hehman, J. A. (2006): Representational and executive selection resources in "theory of mind": Evidence from compromised belief-desire reasoning in old age. Cognition, 101. 129152.

Gopnik, A. és Wellmann, H. M. (1992): Why the Child's Theory of Mind Really Is a Theory. Mind and Language, 7. 145-171.

Gopnik, A. és Meltzoff, A. (1996): Words, Thoughts and Theories. MIT Press, Cambridge.

Gregory, C., Lough, S., Stone, V., Erzinclioglu, S., Martin, L., Baron-Cohen, S. és Hodges, J. R. (2002): Theory of mind in patients with frontal variant frontotemporal dementia and Alzheimer's disease: theoretical and practical implications. Brain, 125. 752-764.

Gunther Moor, B., Op de Maks, Z. A., Güroglu, B., Rombouts, S. A. R. B., Van der Molen, M. W. és Crone, E. A. (2012): Neurodevelopmental changes of reading the mind in the eyes. Social Cognitive and Affective Neuroscience (SCAN), 7. 44-52.

Györi Miklós, Borsos Zsófia és Stefanik Krisztina (2014): A komplex-explicit tudatelmélet és a szocio-kommunikatív tünetek kapcsolatának rövid távú stabilitása autizmus spektrum zavarral élő felnőtteknél: előzetes eredmények. Magyar Pszichológiai Szemle, 69. 1. sz. 117-143. 
Happé, F. (1995): The role of age and verbal ability in the ToM performance of subjects with autism. Child Development, 66. 843-855.

Happé, F. G. E., Winner, E. és Brownell, H. (1998): The getting of wisdom: theory of mind in old age. Developmental Psychology, 34. 2. sz. 358-362.

Harari, H., Shamay-Tsoory, S. G., Ravid, M. és Levkovitz, Y. (2010): Double dissociation between cognitive and affective empathy in borderline personality disorder. Psychiatry Research, 175. 277-279.

Harris, P. L. (1992): From simulation to folk psychology: The case for development. Mind and Language, 7. 120-144.

Henry, J. D., Phillips, L. H., Ruffman, T. és Bailey, P. E. (2013): A meta-analytic review of age differences in theory of mind. Psychology and Aging, 28. 3. sz. 826-839.

Hickok, G. (2009): Eight Problems for the Mirror Neuron Theory of Action Understanding in Monkeys and Humans. Journal of Cognitive Neuroscience, 21. 7. sz. 1229-1243.

Hogrefe, G. J., Wimmer, H. és Perner, J. (1986): Ignorance versus false belief: a developmental lag in attribution of epistemic states. Child Development, 57. 567-582.

Hughes, C. és Ensor, R. (2005): Executive function and theory of mind in 2 year olds: a family affair? Developmental Neuropsychology, 28. 2. sz. 645-668.

Hughes, C. és Ensor, R. (2007): Executive function and theory of mind: Predictive relations from ages 2 to 4. Developmental Psychology, 43. 6. sz. 1447-1459.

Hutton, U. M. Z. és Towse, J. N. (2001): Short-term memory and working memory as indices of children's cognitive skills. Memory, 9. 4-6. sz. 383-394

Ivády Rozália Eszter, Takács, Boglárka és Pléh Csaba (2007): Tudatelmélet és idegen nyelvelsajátítás - valódi kapcsolat vagy városi legenda? In: Kampis György és Mund Katalin (szerk.): Tudat és elme. Budapest: Typotex. 59-74.

Janacsek Karolina, Mészáros Tünde, Tánczos Tímea és Németh Dezső (2009): A munkamemória új magyar nyelvű neuropszichológiai mérőeljárása: a hallási mondatterjedelem teszt (HMT). Magyar Pszichológiai Szemle, 64. 2. sz. 385-406.

Jenkins, J.M. és Astington, J.W. (1996): Cognitive factors and family structure associated with theory of mind development in young children. Developmental Psychology, 32. 70- 78. 
Kalbe, E., Schlegel, M., Sack, A. T., Nowak, D. A., Dafotakis, M., Bangard, C., Brand, M., ShamayTsoory, S., Onur, O. A. és Kessler, J. (2010): Dissociating cognitive from affective theory of mind: a TMS study. Cortex, 46. 769-780.

Kasik László és Gál Zita (2014a): Óvodások szociálisprobléma-megoldó gondolkodása szüleik és pedagógusaik véleménye alapján. Magyar Pedagógia, 114. 3. sz. 189-213.

Kasik László és Gál Zita (2014b): Mit tekintenek 7, 10 és 14 éves diákok személyközi problémának? Iskolakultúra, 34. 9. sz. 3-24.

Kiss Szabolcs és Jakab Zoltán (2010): Az elmeolvasás kutatása napjaink megismeréstudományában. Kultúra és Közösség, 1. 1. sz. 57-72.

Kiss Szabolcs (2005): Elmeolvasás. Budapest: Új Mandátum Kiadó.

Koster-Hale, J. és Saxe, R. (2013): Functional neuroimaging of Theory of Mind. In. Baron-Cohen, S., Tager-Flusberg, H. és Lombardo, M. V. (szerk): Understanding Other Minds: Perspectives from developmental social neuroscience. Oxford University Press. 132-163.

Kovács, Á.M., Téglás, E. és Endress, A.D. (2010): The social sense: susceptibility to others' beliefs in human infants and adults. Science, 330. 1830-1834.

Lalonde, C.E. és Chandler, M.J. (1995): False belief understanding goes to school: On the socialemotional consequences of coming early or late to a first theory of mind. Cognition and Emotion, 9. 167-185.

Lee, T. M. C., Ip, A. K. Y., Wang, K., Xi, C., Hu, P., Mak, H. K. F., Han, S. és Chan, C. C. H. (2010): Faux pas deficit sin people with medial frontal lesions as related to impaired understanding of a speaker's mental state. Neuropsychologia, 48. 1670-1676.

Lewis, C., Freedman, N.H., Kryiakidou, C., Maridaki-Kassotaki, K. és Berridge, D.M. (1996): Social influences on false belief access: Specific sibling influences or general apprenticeship. Child Development, 67.2930-2947.

Liddle, B. és Nettle, D. (2006): Higher-order theory of mind and social competence in school-age children. Journal of Cultural and Evolutionary Psychology, 4. 231-246.

Lieberman, M. D. (2000): Intuition: a social cognitive neuroscience approach. Psychological Bulletin, 126. 109-137.

Lieberman, M. D. (2007): Social cognitive neuroscience: a review of core processes. Annual Review of Psychology, 58. 259-289.

Lieberman, M. D. (2012): Education and the social brain. Trends in Neuroscience and Education, 1. 39.

Lin, S., Keysar, B. és Epley, N. (2010): Reflexively mindblind: Using theory of mind to interpret behavior requires effortful attention. Journal of Experimental Social Psychology, 46. 551-556. 
Lombardo, M. V. és Baron-Cohen, S. (2011): The role of the self in mindblindness in autism. Consciousness and Cognition, 20. 130-140.

Margitics Ferenc, Figula Erika, Pauwlik Zsuzsa és Szatmári Ágnes (2010): A szülői bánásmód hatása az iskolai erőszakkal kapcsolatban előforduló magatartásmintákra. Magyar Pedagógia, 110. 3. sz. 211-238.

Maylor, E. A., Moulson, J. M., Muncer, A. és Taylor, L. A. (2002): Does performance on theory of mind tasks decline in old age? British Journal of Psychology, 93. 465-485.

McAlister, A. és Peterson, C. C. (2007): A longitudinal study of child siblings and theory of mind development. Cognitive Development, 22. 258-270.

McKinnon, M.C. és Moscovitch, M. (2007): Domain-general contributions to social reasoning: Theory of mind and deontic reasoning re-explored. Cognition, 102. 2. sz. 179-218.

Meyer, M. L. és Lieberman, M. D. (2012): Social working memory: Neurocognitive networks and directions for future research. Frontiers in Psychology, 3. 1-11.

Money, C., Davies, H. és Tchanturia, K. (2011): A case study introducing cognitive remediation and emotion skills training for anorexia nervosa inpatient care. Clinical Case Studies, 10. 2. sz. 110121.

Moran, J. M. (2013): Lifespan development: The effects of typical aging on theory of mind. Behavioural Brain Research, 237. 32-40.

Müller, U., Lieberman-Finestone, D. P., Carpendale, J. I. M., Hammond, S. I. és Bibok, M. B. (2012): Knowing minds, controlling actions: The developmental relations between theory of mind and executive function from 2 to 4 years of age. Journal of Experimental Child Psychology, 111. 2. sz. 331-348.

Newton, P., Reddy, V. és Bull, R. (2000): Children's everyday deception and performance on falsebelief tasks. British Journal of Developmental Psychology, 18. 297-317.

Olweus, D. (1994): Bullying at school: Long-term outcomes for the victims and an effective intervention program. In: Huessmann, L. R. (szerk.): Aggressive Behavior: Current Perspectives. Plenum, New York. 97-130.

Onishi, K. H. és Baillargeon, R. (2005): Do 15-month-old infants understand false beliefs? Science, 308. $255-258$.

Pears, K. C. és Moses, L. J. (2003): Demographics, parenting and theory of mind in preschool children. Social Development, 12. 1. sz. 1-20.

Perner, J. (1991): Understanding the representational mind. MIT Press.

Perner, J. és Lang, B. (1999): Why the Child's Theory of Mind Really Is a Theory. Mind and Language, 7. 145-171. 
Perner, J., Ruffman, T. és Leekam, S. (1994): Theory of Mind is contagious: You Catch it from your sibs. Child Development, 65. 1228-1238.

Peterson, C. és Slaughter, V. (2003): Opening windows into the mind: mothers' preferences for mental state explanations and children's theory of mind. Cognitive Development, 18. 399-429.

Poletti, M., Enrici, I., Bonuccelli, U. és Adenzato, M. (2011): Theory of mind in Parkinson's disease. Behavioural Brain Research, 36. 2147-2164.

Poletti, M., Vergallo, A., Ulivi, M., Sonnoli, A. és Bonucelli, U. (2013): Affective theory of mind in patients with Parkinson's disease. Psychiatry and Clinical Neurosciences, 67. 273-276.

Premack, D. és Woodruff, G. (1978): Does the chimpanzee have a „theory of mind”? Behavioral and Brain Sciences, 4. 515-526.

Qureshi, A., Apperly, I.A. és Samson, D. (2010): Executive function is necessary for perspectiveselection, not Level-1 visual perspective-calculation: Evidence from a dual-task study of adults. Cognition, 117. 2. sz. 230-236.

Racsmány Mihály, Lukács Ágnes, Németh Dezső és Pléh Csaba (2005): A verbális munkamemória magyar nyelvü vizsgálóeljárásai. Magyar Pszichológiai Szemle, 4. 479-505.

Ragsdale, G. és Foley, R. A. (2011): A maternal influence on Reading the Mind in the Eyes mediated by executive function: differential parental influences on full and half-siblings. Plos One, 6. 8. sz. 1-9.

Razza, R. A. és Blair, C. (2009): Associations among false-belief understanding, executive function, and social competence: A longitudinal analysis. Journal of Applied Developmental Psychology, 30. 3. sz. 332-343.

Ruffman, T., Slade, L. és Crowe, E. (2002): The relation between children's and mothers' mental state language and theory-of-mind understanding. Child Development, 73. 734-751.

Ruffman, T., Slade, L. és Crowe, E. (2002): The relation between children's and mothers' mental state language and theory-of-mind understanding. Child Development, 73. 734-751.

Ruffman, T., Slade, L., Devitt, K és Crowe, E. (2006): What mothers say and what they do: The relation between parenting, theory of mind, language and conflict/cooperation. British Journal of Development Psychology: Special Issue, 24. 105-124.

Russel, J. (1996): Agency: Its role in mental development. Psychology Press.

Russel, T. A., Schmidt, U., Doherty, L., Young, V. és Tchanturia, K. (2009): Aspects of social cognition in anorexia nervosa: Affective and cognitive theory of mind. Psychiatry Research, 168. $181-185$. 
Samson, D., Apperly I. A., Chiavarino, C. és Humphreys, G. W. (2004): Left temporoparietal junction is necessary for representing someone else's belief. Nature Neuroscience, 7. 499-500.

Sania, S., Jaffee, S. R., Bowes, L., Ouellett-Morin, I., Andreou, P., Happé, F., Moffitt, T. E. és Arseneault, L. (2012): A prospective longitudinal study of children's theory of mind and adolescent involvement in bullying. Journal of Child Psychology and Psychiatry, 53. 3. sz. 254261.

Saxe, R. (2006): Uniquely human social cognition. Current Opinion in Neurobiology, 16. 235-239.

Sebastian, C. L., Fontaine, N. M. G., Bird, G., Blakemore, S-J., De Brito, S. A., McCrory, E. J. P. és Viding, E. (2012): Neural processing associated with cognitive and affective Theory of Mind in adolescents and adults. Social Cognitive and Affective Neuroscience (SCAN), 7. 1. sz. 53-63.

Senju, A. (2013): Atypical development of spontaneous social cognition in autism spectrum disorders. Brain and Development, 35. 96-101.

Shamay-Tsoory, S. G., Harari, H., Aharon-Peretz, J. és Levkovitz, Y. (2010): The role of the orbitofrontal cortex in affective theory of mind deficits in criminal offenders with psychopathic tendencies. Cortex, 46. 5. sz. 668-677.

Shamay-Tsoory, S. G., Shur, S., Barcai-Goodman, L., Medlovich, S., Harari, H. és Levkovitz, Y. (2007): Dissociation of cognitive from affective components of theory of mind in schizophrenia. Psychiatry Research, 149. 11-23.

Slade, L. és Ruffman, T. (2005): How language does (and does not) relate to theory of mind: A longitudinal study of syntax, semantics, working memory and false belief. British Journal of Developmental Psychology, 23. 117-141.

Slaughter, V. és Repacholi, B. (2003): Introduction: Individual Differences in Theory of Mind. What Are We Investigating? In: Repacholi, B. és Slaughter, V. (szerk.): Individual differencies in Theory of Mind. Implications for typical and atypical development. New York: Psychology Press. 1-14.

Slaughter, V., Dennis, M. J. és Pritchard, M. (2002): Theory of mind and peer acceptance in preschool children. BritishJournalof Developmental Psychology, 20. 545 -564.

Slaughter, V., Imuta, K., Peterson, C. C. és Henry, J. D. (2015): Meta-analysis of theory of mind and peer popularity in the preschool and early school years. Child Development, DOI: $10.1111 /$ cdev.12372

Sommer, M., Dohnel, K., Sodian, B., Meinhardt, J., Thoermer, C. és Hajak, G. (2007): Neural correlates of true and false belief reasoning. NeuroImage, 35. 1378-1384.

Stefanik Krisztina (2005): Az iskoláskorra vonatkozó prognózis kérdése autizmusban - a korai képességmintázat és a naiv tudatelméleti vonatkozású viselkedések szerepe. PhD Disszertáció. Budapest: Eötvös Loránd Tudományegyetem. 
Stone, V. (2000): The role of the frontal lobes and the amygdala in theory of mind. In. Baron-Cohen, S., Cohen, D. és Tager-Flusberg, H. (szerk): Understanding Other Minds: Perspectives from autism and developmental cognitive neuroscience. Oxford University Press. 259-273.

Stone, V., Baron-Cohen, S., Calder, A., Keane, J. és Young, A. (2003): Acquired theory of mind impairments in individuals with bilateral amygdala lesions. Neuropsychologia, 41. 209-220.

Stone, V., Baron-Cohen, S. és Knight, R. T. (1998): Frontal Lobe Contributions to Theory of Mind. Journal of Cognitive Neuroscience, 5. 640-656.

Suddendorf, T. és Fletcher-Flinn, C.M. (1999): Children's divergent thinking improves when they understand false beliefs. Creativity Research Journal, 12. 115-128.

Sutton, J. (2003): ToM Goes to School. Social Cognition and Social Values in Bullying. In: Repacholi, B. és Slaughter, V. (szerk.): Individual differencies in Theory of Mind. Implications for typical and atypical development. New York: Psychology Press. 99-122.

Tchanturia, K., Davies, H. és Campbell, I. C. (2007): Cognitive remediation therapy for patients with anorexia nervosa: preliminary findings. Annals of General Psychiatry, 14. 6-14.

Tchanturia, K., Happé, F., Godley, J., Treasure, J., Bara-Carril, N. és Schmidt, U. (2004): „Theory of Mind" in Anorexia Nervosa. European Eating Disorders Review, 12. 1-6.

Tine, M. és Lucariello, J. (2012): Unique theory of mind differentiation in children with autism and Asperger Syndrome. Autism Research and Treatment, 2012. 1-11.

Uekermann, J., Kraemer, M., Abdel-Hamid, M., Schimmelmann, B. G., Hebebrand, J., Daum, I., Wiltfang, J. és Kis B. (2010): Social cognition in attention-deficit hyperactivity disorder (ADHD). Neuroscience and Biobehavioral Reviews, 34. 734-743.

Varga E., Tényi T., Fekete S., és Herold R. (2008): Mentalizációs deficit vizsgálata Faux Pas Teszttel skizofréniában, Neuropsychopharmacologia Hungarica, 10. 2. sz., 67-72.

Vetter, N. C., Altgassen, M., Phillips, S., Mahy, C. E. V. és Kliegel, M. (2013): Development of Affective Theory of Mind Across Adolescence: Disentangling the Role of Executive Functions. Developmental Neuropsychology, 38. 2. sz. 114-125

Walker, S. (2005): Gender Differences in the Relationship Between Young Children's Peer-Related Social Competence and Individual Differences in Theory of Mind. The Journal of Genetic Psychology, 116. 3. sz. 297-312.

Wang, Y. és Su, Y. (2006): Theory of mind in old adults: the performance on Happé's stories and faux pas stories. Psychologia, 49. 4. sz. 228-237.

Watson, A. C., Nixon, C. L., Wilson, A. és Capage, L. (1999): Social interacton skills and Theory of Mind in young children. Developmental Psychology, 35. 2. sz. 386-391.

Wellman, H. M. és Liu, D. (2004): Scaling of theory of mind tasks. Child Development, 75. 523-541. 
Wellman, H. M., Fang, F., Peterson, C. C. (2011): Sequential Progressions in a Theory of Mind Scale: Longitudinal Perspectives. Child Development, 82. 3. sz. 780-792.

Westby, C. és Robinson, L. (2014): A Developmental Perspective for Promoting Theory of Mind. Topics in Language Disorders, 34. 4. sz. 362-382.

Wimmer, H. és Perner, J. (1983): Beliefs about beliefs: representation and contraining function of wrong beliefs in young children's understanding of deception. Cognition, 13. 103-128. 


\section{MELLÉKLET: A VIZSGÁlATBAN ALKALMAZOTT TESZTEK}

\section{Másodfokú, verbális hamis vélekedés-tulajdonítási feladat (Stefanik, 2005 nyomán)}

A vizsgálatvezető szövege (a szöveget a történet képen történő mutatása kíséri):

Elmesélek egy történetet. Egy faluban játszódik. Nézd, ezek itt a házak, ez itt a templom.

A falunak van egy parkja is, ez itt. Két gyerek játszik benne.

Ez Jancsi, ez pedig itt Mari.

Megértést segítő kontrollkérdés 1: Melyik Jancsi? Melyik Mari?

Itt vannak mind a ketten a parkban. Amott jön a fagylaltárus. Jancsi szeretne fagyit venni, de nincs nála pénz. Nagyon szomorú emiatt.

- Ne aggódj - mondja neki a fagylaltárus, - menj csak haza, hozzál pénzt, és később is vehetsz fagyit. Egész délután itt leszek a parkban...

- Nagyon jó - mondja Jancsi, - délután visszajövök fagyit venni.

Megértést segítő kontrollkérdés 2: Mit mondott a fagylaltárus Jancsinak, hol lesz egész délután?

Jancsi tehát hazamegy. Itt lakik, ebben a házban. A fagylaltárus közben azt mondja magában:

- Inkább átmegyek a templomhoz, talán ott több fagyit tudok eladni.

Megértést segítő kontrollkérdés 3: Mit mondott most a fagylaltárus, hová fog menni?

Megértést segítő kontrollkérdés 4: Hallotta Jancsi, amit a fagylaltárus mondott?

A fagylaltárus tehát átmegy a templom elé a kocsijával. Útközben elmegy Jancsiék háza elött. Jancsi észreveszi őt, kimegy hozzá, és azt kérdezi:

- Hová mégy?

A fagylaltárus azt mondja neki:

- Megyek a templom elé, ott fogok fagyit árulni.

El is megy a templomhoz. Egy kicsit később pedig Jancsi is utánamegy.

Megértést segítő kontrollkérdés 5: Mit mondott most a fagylaltárus Jancsinak, hová fog menni?

Megértést segítő kontrollkérdés 6. Mari tudja, hogy a fagylaltárus beszélt Jancsival?

Közben Mari is hazamegy. Itt lakik, ebben a házban. Aztán elindul megkeresni Jancsit, és elmegy Jancsiék házához. Bekopog az ajtón, kijön Jancsi anyukája, és Mari megkérdezi:

- Itthon van Jancsi?

- Nincsen, elment fagyit venni.

Tesztkérdés: Mit gondol Mari, hová ment Jancsi fagyit venni?

Indoklás: Miért gondolja ezt Mari?

Kontrollkérdés (realitás): Hová ment igazából Jancsi fagyit venni?

Kontrollkérdés (emlékezet): Hol volt a fagylaltárus a történet legelején? 


\section{Faces Teszt}

\begin{tabular}{|l|l|l|}
\hline Arc & Érzelem 1 & Érzelem 2 \\
\hline 1 & meglepödött & boldog \\
\hline 2 & dühös & ijedt \\
\hline 3 & boldog & meglepödött \\
\hline 4 & undor & szomorú \\
\hline 5 & undor & szomorú \\
\hline 6 & dühös & ijedt \\
\hline 7 & boldog & meglepödött \\
\hline 8 & kétségbeesett & szomorú \\
\hline 9 & meglepödött & boldog \\
\hline 10 & dühös & ijedt \\
\hline 11 & áskálódó & arrogáns \\
\hline 12 & arrogáns & büntudatos \\
\hline 13 & elmélkedő & arrogáns \\
\hline 14 & meglepödött & rajongó \\
\hline 15 & kötekedö & büntudatos \\
\hline 16 & boldog & flörtölö \\
\hline 17 & unatkozó & álmos \\
\hline 18 & közönyös & érdeklödö \\
\hline 19 & érdeklődő & közönyös \\
\hline 20 & büntudatos & arrogáns \\
\hline
\end{tabular}




\section{Faux Pas Felismerése Teszt}

\section{Gyermekváltozat}

Faux Pas történetek

1. Az egész osztály benevezett az iskolai mesemondó versenyre. Emma nagyon szeretett volna nyerni. Amíg ő nem volt ott az iskolában, addig kihirdették a verseny eredményét: Aliz nyert. Másnap, amikor Aliz meglátta Emmát, így szólt: „Sajnálom, hogy nem díjazták a mesédet”. „Mire gondolsz?” - kérdezte Emma. „Jaj, semmi” - mondta Aliz.

Mondott bárki valami olyat, amit nem kellett volna, vagy valami olyat, ami nem volt odaillő?

Ha a vsz. válasza igen:

Mi volt az, amit nem kellett volna mondania?

Ki nyerte a mesemondó versenyt?

Vajon Aliz tudhatta, hogy Emma nem hallotta az eredményhirdetést?

2. Róbert csak most kezdett egy új iskolában. Azt mondta az új barátjának, Andrásnak: „Képzeld, anyukám ebben az iskolában konyhás néni”. Aztán Klára jött oda hozzájuk: „Utálom a konyhás néniket. Szörnyüek”. „Akarsz velünk tollasozni?” - kérdezte András Klárától. „Nem”válaszolta Klára „Nem érzem jól magam”.

Mondott bárki valami olyat, amit nem kellett volna, vagy valami olyat, ami nem volt odaillő?

Ha a vsz. válasza igen:

Mi volt az, amit nem kellett volna mondania?

Mi a foglalkozása Róbert anyukájának?

Tudhatta Klára, hogy Róbert anyukája konyhás néni?

3. Miki épp az iskolai WC egyik fülkéjében volt, Józsi és Péter pedig a kézmosóknál álltak. Józsi így szólt: „Tudod, van az az új fiú az osztályban, Mikinek hívják. Szerinted nem néz ki nagyon furcsán?”. Ekkor Miki kilépett a fülkéből. Péter így szólt: „Szia, Miki, lenne most kedved focizni?”.

Mondott bárki valami olyat, amit nem kellett volna, vagy valami olyat, ami nem volt odaillö?

Ha a vsz. válasza igen:

Mi volt az, amit nem kellett volna mondania?

Hol volt Józsi és Péter, amikor beszélgettek?

Vajon tudta Józsi, hogy Miki az egyik fülkében van?

4. Évi segített az anyukájának almás pitét készíteni, mert a nagybátyja eljött őket meglátogatni. Kivitte a pitét a konyhából. „Nézd, ezt neked sütöttem” - mondta Évi. „Mmm” - válaszolt a nagybátyja. „Jól néz ki. Imádom a pitét, csak az almásat nem.”

Mondott bárki valami olyat, amit nem kellett volna, vagy valami olyat, ami nem volt odaillő? 
Ha a vsz. válasza igen:

Mi volt az, amit nem kellett volna mondania?

Milyen pitét sütött Évi?

Tudta a nagybátyja, hogy az a pite almás volt?

5. Ákos egy játékrepülőt vett ajándékba Ricsinek születésnapjára. Néhány hónappal később ezzel a repülővel játszottak, és Ákos véletlenül leejtette. „Ne aggódj” - mondta Ricsi „Amúgy sem szerettem ezt a játékot. A szülinapomra kaptam valakitől”.

Mondott bárki valami olyat, amit nem kellett volna, vagy valami olyat, ami nem volt odaillö?

Ha a vsz. válasza igen:

Mi volt az, amit nem kellett volna mondania?

Mit ajándékozott Ákos Ricsinek a szülinapjára?

Emlékezett Ricsi, hogy a játékrepülőt Ákostól kapta szülinapjára?

6. Szilvinek rövid szőke haja van. Épp a nagynénjénél, Margónál volt látogatóban. Csengettek, Mária jött, a szomszéd. Mária így szólt: „Hello”. Szilvire nézett és azt mondta: „Nem hiszem, hogy találkoztam már ezzel a kisfiúval. Hogy hívnak?”. Margó így szólt: „Hozhatok nektek teát?”.

Mondott bárki valami olyat, amit nem kellett volna, vagy valami olyat, ami nem volt odaillő?

Ha a vsz. válasza igen:

Mi volt az, amit nem kellett volna mondania?

Kinél volt látogatóban Szilvi?

Mária tudta, hogy Szilvi kislány?

7. Anna néni, az osztály tanítónője úgy érezte, hogy el kell mondania valamit az osztálynak, „Az osztályunkba járó egyik fiú, Soma, nagyon súlyos beteg”. Az egész osztály nagyon szomorú lett, és csendben ültek, amikor az egyik kislány, Viki késve megérkezett. „Hallottátok az új viccemet a beteg emberekről?” - kérdezte. A tanítónő így szólt: „Ülj le a helyedre, és kezdd el a feladatod”.

Mondott bárki valami olyat, amit nem kellett volna, vagy valami olyat, ami nem volt odaillő?

Ha a vsz. válasza igen:

Mi volt az, amit nem kellett volna mondania?

Mit mesélt el a tanítónő a történet elején az osztályának?

Viki tudhatta, hogy Soma nagyon beteg?

8. Tamás egy étteremben kávézott. Véletlenül leejtette a kávéját a padlóra. Ádám az étterem másik vendége volt, éppen a kasszánál állt, fizetni szeretett volna. Tamás odalépett Ádámhoz és így szólt: „Szörnyen sajnálom, kiöntöttem a kávémat. Tudna segíteni és feltörölné?”.

Mondott bárki valami olyat, amit nem kellett volna, vagy valami olyat, ami nem volt odaillő?

Ha a vsz. válasza igen:

Mi volt az, amit nem kellett volna mondania? 
Hol játszódik a történet?

Tudhatta Tamás, hogy Ádám is vendég?

9. Nóriék most költöztek be az új házukba. Nóri és anyukája vásárolni mentek, és új függönyöket vettek a lakásba. Ahogyan feltették a függönyöket, Nóri legjobb barátnője, Zsuzsi átjött hozzájuk és így szólt: „Ezek a függönyök szörnyüek, remélem, vesztek majd újakat”. Mire Nóri azt kérdezte: „A szobám többi része azért tetszik?”.

Mondott bárki valami olyat, amit nem kellett volna, vagy valami olyat, ami nem volt odaillő?

Ha a vsz. válasza igen:

Mi volt az, amit nem kellett volna mondania?

Mit vásárolt Nóri?

Tudhatta Zsuzsi, hogy a függönyök újak voltak?

10. Heni anyukája meglepetésbulit szervezett Heni szülinapjára. Meghívta Nikit és így szólt: „Nehogy elmondd bárkinek is, főleg Heninek ne!”. A buli előtti napon Heni és Niki együtt játszottak, és Niki kiszakította a ruháját. „Jaj!” - mondta Niki „Ezt akartam felvenni a bulidra!”. „Milyen bulira?” - kérdezte Heni. „Gyere!” - szólt Niki „Kérdezzük meg, hogy anyukám meg tudja-e varrni a ruhát”.

Mondott bárki valami olyat, amit nem kellett volna, vagy valami olyat, ami nem volt odaillő?

Ha a vsz. válasza igen:

Mi volt az, amit nem kellett volna mondania?

Kinek szerveztek meglepetés bulit?

Emlékezett Niki, hogy a buli meglepetés? 


\section{Felnőtt változat}

1. Viki egy barátjánál, Ádámnál volt buliban. Éppen Ádámmal beszélgetett, amikor egy hölgy jött fel hozzájuk. Ő Ádám egyik szomszédja volt. A hölgy azt mondta, „Helló”, majd Vikihez fordult, és azt mondta: „Nem hiszem, hogy találkoztunk. Mária vagyok, téged hogy hívnak?” „Viki vagyok.” „Szeretne valaki valamit inni?” - kérdezte Ádám.

Mondott bárki valami olyat, amit nem kellett volna, vagy valami olyat, ami nem volt odaillö?

Ha igen:

Ki mondott olyat, amit nem kellett volna, vagy valami olyat, ami nem volt odaillő?

Mért nem kellett volna neki ezt mondania, vagy miért nem volt ez odaillö?

Mit gondol, miért mondta ezt?

Ádám tudta-e, hogy Viki és Mária nem ismerik egymást?

Mit gondol, hogyan érezte magát Viki?

Kontrollkérdések:

Hol volt Viki a történet szerint?

Viki és Mária ismerték egymást?

2. Anita férje meglepetésbulit szervezett a felesége születésnapjára. Meghívta Sárát is, Anita egyik barátnőjét, és azt mondta, „Ne mondd el senkinek, föleg Anitának ne.” A buli előtti napon Anita Sáránál volt, és Sára kilöttyintett egy kis kávét az új ruhára, ami a székre volt akasztva. „Oh!” mondta Sára. „A bulidra akartam felvenni ezt a ruhát.” „Milyen bulira?” - kérdezte Anita. „Gyere!”szólt Sára, „Nézzük meg, ki tudjuk-e venni belöle a foltot.”

Mondott bárki valami olyat, amit nem kellett volna, vagy valami olyat, ami nem volt odaillö?

Ha igen:

Ki mondott olyat, amit nem kellett volna, vagy valami olyat, ami nem volt odaillő?

Mért nem kellett volna neki ezt mondania, vagy miért volt ez nem odaillö?

Mit gondol, miért mondta ezt?

Vajon Sára emlékezett, hogy a buli az meglepetés buli volt?

Mit gondol, hogy érezhette magát Anita?

Kontrollkérdések:

A történetben kinek volt meglepetés bulija?

Mi löttyent a ruhára? 
3. András vásárolni akart egy inget, ami illik az öltönyéhez. Az eladó jó néhány inget megmutatott neki. András megnézte őket, és végül talált egyet, ami színben megfelelő volt. De amikor bement a próbafülkébe, hogy felpróbálja, nem volt jó. „Azt hiszem, ez túl kicsi” - mondta az eladónak. „Nincs miért aggódnia” - mondta az eladó „Jövő héten kapunk néhányat nagyobb méretben.” „Remek, akkor majd visszajövök” - mondta András.

Mondott bárki valami olyat, amit nem kellett volna, vagy valami olyat, ami nem volt odaillő?

Ha igen:

Ki mondott olyat, amit nem kellett volna, vagy valami olyat, ami nem volt odaillö?

Mért nem kellett volna neki ezt mondania, vagy miért volt ez nem odaillő?

Mit gondol, miért mondta ezt?

Amikor felpróbálta az inget, vajon András tudta, hogy nincs az ő méretében?

Mit gondol, hogyan érezhetett András?

Kontrollkérdések:

A történetben András mit akart vásárolni?

Miért akar visszajönni a következő héten?

4. Dóra épp most költözött át új lakásába. Elment vásárolni, és vett néhány új függönyt a hálószobájába. Éppen, amikor befejezte a lakás dekorálását, akkor jött át a legjobb barátnője, Liza. Dóra körbevezette öt a lakásban, majd megkérdezte: „Hogy tetszik a hálószobám?” „Azok a függönyök szörnyüek” - mondta Liza. „Remélem, veszel majd újakat!”

Mondott bárki valami olyat, amit nem kellett volna, vagy valami olyat, ami nem volt odaillő?

Ha igen:

Ki mondott olyat, amit nem kellett volna, vagy valami olyat, ami nem volt odaillö?

Mért nem kellett volna neki ezt mondania, vagy miért volt ez nem odaillő?

Mit gondol, miért mondta ezt?

Vajon Liza tudta, hogy ki vásárolta a függönyöket?

Mit gondol, hogyan érezhette magát Dóra?

Kontrollkérdések:

A történetben mit vásárolt éppen akkor Dóra?

Mióta élt Dóra ebben a lakásban? 
5. Ákos elment a fodrászhoz, hogy levágassa a haját. „Milyenre szeretné, hogy levágjam?” kérdezte a fodrász. „Ugyanezt a fazont szeretném, mint ami most van, csak néhány centit vágjon belöle" - válaszolta Ákos. A fodrász egy kicsit egyenetlenre vágta az elejét, így rövidebbre kellett vágnia, hogy kiegyenlítse. „Attól tartok, ez kicsivel rövidebb, mint ahogy kérte” - mondta a fodrász. „Ó, nem baj!” - mondta Ákos, „majd megnő.”

Mondott bárki valami olyat, amit nem kellett volna, vagy valami olyat, ami nem volt odaillő?

Ha igen:

Ki mondott olyat, amit nem kellett volna, vagy valami olyat, ami nem volt odaillő?

Mért nem kellett volna neki ezt mondania, vagy miért volt ez nem odaillö?

Mit gondol, miért mondta ezt?

Amíg vágták a haját, vajon Ákos tudta, hogy a fodrász túl rövidre vágta?

Mit gondol, hogyan érezhette magát Ákos?

Kontrollkérdések:

A történetben milyenre szerette volna Ákos a hajvágást?

Milyenre vágta le a fodrász a haját?

6. János hazafelé tartva megállt a benzinkúton, hogy teletankolja a kocsiját. Odaadta a pénztárosnak a hitelkártyáját. A pénztáros lehúzta a gépen a pultnál. „Sajnálom” - mondta, ,,a gép nem fogadja el az ön kártyáját.” „Hmm, ez érdekes” - mondta János. „Nos, akkor majd készpénzzel fizetek.” Tízezer forintot adott neki és azt mondta: „Ólommentessel tankoltam.”

Mondott bárki valami olyat, amit nem kellett volna, vagy valami olyat, ami nem volt odaillö?

Ha igen:

Ki mondott olyat, amit nem kellett volna, vagy valami olyat, ami nem volt odaillő?

Mért nem kellett volna neki ezt mondania, vagy miért volt ez nem odaillö?

Mit gondol, miért mondta ezt?

Amikor átadta a kártyáját a pénztárosnak, vajon János tudta, hogy a gép nem fogja azt elfogadni?

Mit gondol, hogyan érezhette magát János?

Kontrollkérdések:

A történetben miért állt meg János hazafelé?

Miért fizetett készpénzzel? 
7. Szilvi egy hároméves, kerek arcú, rövid, szőke hajú kislány. Nagynénjénél, Évánál volt. Szólt a csengö, és a nagynénje megnézte, ki jött. Marika volt az, az egyik szomszéd. Éva néni azt mondta, „Szia! Kedves tőled, hogy benéztél.” Marika így szólt: „Helló”, majd ránézett Szilvire és azt mondta „Nem hiszem, hogy találkoztam már ezzel a kicsi fiúval. Hogy hívnak?”

Mondott bárki valami olyat, amit nem kellett volna, vagy valami olyat, ami nem volt odaillő?

Ha igen:

Ki mondott olyat, amit nem kellett volna, vagy valami olyat, ami nem volt odaillö?

Mért nem kellett volna neki ezt mondania, vagy miért volt ez nem odaillő?

Mit gondol, miért mondta ezt?

Marika vajon tudta, hogy Szilvi lány?

Mit gondol, hogy érezhette magát Szilvi?

Kontrollkérdések:

A történet szerint hol volt Szilvi?

Ki jött látogatóba?

8. Ági kivitte a kutyáját, Rexet a parkba. Eldobott egy ágat, hogy kapja el. Amikor már egy ideje ott voltak, Ildi, egyik szomszédjuk, elhaladt mellettük. Csevegtek pár percig. Majd Ildi megkérdezte: „Hazafelé tartasz? Mehetünk együtt?” „Persze” - mondta Ági. Hívta Rexet, de ő éppen galambokat kergetett, így nem jött. „Úgy néz ki, nem akar még jönni” - mondta. „Azt hiszem, maradunk.” „Oké!” - mondta Ildi. „Majd találkozunk.”

Mondott bárki valami olyat, amit nem kellett volna, vagy valami olyat, ami nem volt odaillő? Ha igen:

Ki mondott olyat, amit nem kellett volna, vagy valami olyat, ami nem volt odaillö?

Mért nem kellett volna neki ezt mondania, vagy miért volt ez nem odaillö?

Mit gondol, miért mondta ezt?

Amikor hívta őt, vajon Ildi tudta, hogy Ági nem tud majd jönni?

Mit gondol, hogy érezhette magát Ildi?

Kontrollkérdések:

A történetben hova vitte Ági Rexet?

Miért nem sétált a barátnőjével, Ildivel? 
9. Juditnak tavaly egy fontos szerepe volt az iskolai darabban, ebben az évben pedig nagyon szerette volna a föszerepet megkapni. Színjátszásórákat is vett, és tavasszal elment a szerep meghallgatására. Aznap, amikor a döntést közzétették, az óra elött elment, hogy megnézze a listát, kik kaptak szerepet. Nem kapta meg a föszerepet, hanem egy kis szerepre osztották be. A barátjához rohant az aulába, és elmesélte neki, mi történt. „Sajnálom” - mondta. „Biztosan csalódott lehetsz.” „Igen” - válaszolt Judit. „El kell döntenem, hogy elfogadjam-e ezt a szerepet.”

Mondott bárki valami olyat, amit nem kellett volna, vagy valami olyat, ami nem volt odaillö?

Ha igen:

Ki mondott olyat, amit nem kellett volna, vagy valami olyat, ami nem volt odaillö?

Mért nem kellett volna neki ezt mondania, vagy miért volt ez nem odaillö?

Mit gondol, miért mondta ezt?

Amikor elöször odafutott a hallban, vajon tudta Judit barátja, hogy nem kapta meg a szerepet?

Mit gondol, hogyan érezhette magát Judit?

Kontrollkérdések:

A történetben milyen szerepet kapott Judit?

Milyen szerepe volt az előző évben?

Mit mondott a barátja?

10. Egyszer Zoli a könyvtárban volt. Megtalálta a könyvet, amit keresett, a grand canyon-beli túrázásról, és odament az elöl lévő pulthoz, hogy kivegye. Amikor belenézett a pénztárcájába, észrevette, hogy olvasójegyét otthon hagyta. „Sajnálom” - mondta a pult mögött álló hölgynek. „Úgy tünik, otthon hagytam az olvasójegyem.” „Rendben van, semmi gond” - válaszolt. „Csak mondja meg a nevét, és ha fenn van a számítógépen és megmutatja a jogosítványát, kiveheti a könyvet.”

Mondott bárki valami olyat, amit nem kellett volna, vagy valami olyat, ami nem volt odaillő?

Ha igen:

Ki mondott olyat, amit nem kellett volna, vagy valami olyat, ami nem volt odaillő?

Mért nem kellett volna neki ezt mondania, vagy miért volt ez nem odaillö?

Mit gondol, miért mondta ezt?

Amikor Zoli a könyvtárba ment, tisztában volt azzal, hogy nincs nála az olvasójegye?

Mit gondol, hogy érezhette magát Zoli?

Kontrollkérdések:

A történet szerint Zoli milyen könyvet talált a könyvtárban?

Sikerült kivennie a könyvet? 
11. Nagy Réka, az Abco Szoftverfejlesztő cég igazgatója egy megbeszélésre hívta a teljes személyzetet. „Valamit el kell mondanom nektek” - mondta. „Mészáros János, az egyik könyvelőnk nagyon beteg, rákos és kórházban van." Mindenki csendben maradt, feldolgozta a híreket, amikor Róbert, egy informatikus késve megérkezett. „Hé, tegnap este hallottam ezt a nagyszerü viccet!” mondta Róbert. „Mit mondott a végső stádiumban lévő beteg az orvosának?” Réka erre azt mondta: „Oké, foglalkozzunk most már az üzlettel ezen a megbeszélésen.”

Mondott bárki valami olyat, amit nem kellett volna, vagy valami olyat, ami nem volt odaillő?

Ha igen:

Ki mondott olyat, amit nem kellett volna, vagy valami olyat, ami nem volt odaillö?

Mért nem kellett volna neki ezt mondania, vagy miért volt ez nem odaillö?

Mit gondol, miért mondta ezt?

Amikor belépett, vajon Róbert tudta, hogy a könyvelő rákbeteg?

Mit gondol, hogy érezte magát Réka, az igazgató?

Kontrollkérdések:

A történetben mit mondott Réka, az igazgató a megbeszélésen?

Ki érkezett késve a megbeszélésre?

12. Miki, egy kilencéves fiú épp most kezdett új iskolájában. Épp a mosdó egyik fülkéjében volt. Zoli és Péter, két másik fiú, bejöttek, a mosdóknál megálltak és beszélgettek. Zoli azt mondta: „Te ismered az új fiút az osztályban? Mikinek hívják. Nem látod kicsit furcsának? És annyira alacsony.” Miki kijött a fülkéből, Zoli és Péter meglátták. Péter azt mondta: „Ó, szia, Miki! Jössz ki focizni?”

Mondott bárki valami olyat, amit nem kellett volna, vagy valami olyat, ami nem volt odailló?

Ha igen:

Ki mondott olyat, amit nem kellett volna, vagy valami olyat, ami nem volt odaillö?

Mért nem kellett volna neki ezt mondania, vagy miért volt ez nem odaillö?

Mit gondol, miért mondta ezt?

Amikor Zoli és Péter beszélgettek, tudták, hogy Miki ott van egy fülkében?

Mit gondol, hogyan érezhette magát Miki?

Kontrollkérdések:

A történet szerint hol volt Miki, amíg Zoli és Péter beszélgettek?

Mit mondott Zoli Mikiröl? 
13. Andi unokatestvérét, Danit várja látogatóba, és almás pitét készített számára. A vacsora után azt mondta „Csináltam neked pitét. A konyhában van.” „Mmmm” - válaszolt Dani. „Jó illata van! Szeretem a pitét, csak az almásat nem."

Mondott bárki valami olyat, amit nem kellett volna, vagy valami olyat, ami nem volt odaillö?

Ha igen:

Ki mondott olyat, amit nem kellett volna, vagy valami olyat, ami nem volt odaillö?

Mért nem kellett volna neki ezt mondania, vagy miért volt ez nem odaillő?

Mit gondol, miért mondta ezt?

Amikor megszagolta a pitét, tudta Dani, hogy az almás?

Mit gondol, hogyan érezhette magát Andi?

Kontrollkérdések:

A történetben milyen fajta pitét készített Andi?

Honnan ismerte egymást Andi és Dani?

14. Zsanett vásárolt egy kristálytálat egy barátjának, Annának nászajándékba. Annának nagy esküvője volt, sok ajándékkal, amikre mind figyelnie kellett. Körülbelül egy évvel később Zsanett Annánál volt egy este vacsorán. Zsanett véletlenül ráejtett egy üveg bort a kristálytálra és a tál összetört. „Nagyon sajnálom. Összetörtem a tálat” - mondta Zsanett. „Ne aggódj” - mondta Anna. „Nekem soha nem tetszett. Az esküvőmre kaptam valakitől.”

Mondott bárki valami olyat, amit nem kellett volna, vagy valami olyat, ami nem volt odaillö?

Ha igen:

Ki mondott olyat, amit nem kellett volna, vagy valami olyat, ami nem volt odaillö?

Mért nem kellett volna neki ezt mondania, vagy miért volt ez nem odaillő?

Mit gondol, miért mondta ezt?

Anna emlékezett arra, hogy Zsanett adta neki a tálat?

Mit gondol, hogyan érezhetett Zsanett?

Kontrollkérdések:

A történetben mit adott Zsanett nászajándékba Annának?

Hogyan tört el a tál? 
15. A Főtéri Általános Iskolában mesemondó verseny volt. Mindenkinek szóltak, hogy nevezzen be a versenybe. Néhányan az ötödik osztályosok közül is ezt tették. Kriszti, egy ötödikes, imádott egy mesét, amivel be is nevezett a versenybe. Néhány nappal később kihirdették a verseny eredményét: Kriszti meséje nem nyert, egy osztálytársa, Csaba nyerte az első díjat. A következő napon Kriszti Csabával ült egy padon. Az első díjért járó trófeát nézték. Csaba azt mondta: „Nagyon könnyü volt megnyerni a versenyt. Minden versenyben szereplő történet szörnyü volt.” „Hová fogod tenni a trófeádat?" - kérdezte Kriszti.

Mondott bárki valami olyat, amit nem kellett volna, vagy valami olyat, ami nem volt odaillö?

Ha igen:

Ki mondott olyat, amit nem kellett volna, vagy valami olyat, ami nem volt odaillö?

Mért nem kellett volna neki ezt mondania, vagy miért volt ez nem odaillö?

Mit gondol, miért mondta ezt?

Tudta vajon Csaba, hogy Kriszti is benevezett egy történettel a versenybe?

Mit gondol, hogyan érezhette magát Kriszti?

Kontrollkérdések:

A történetben ki nyerte a versenyt?

Nyert valamit Kriszti meséje?

16. Tamás egy étteremben volt. Véletlenül egy kis kávét löttyintett a padlóra. „Hozok Önnek egy másik csésze kávét" - mondta a pincér. A pincér elment egy időre. Feri, aki egy másik vendég volt az étteremben, a pénztárnál állva várt arra, hogy fizethessen. Tamás odament Ferihez és így szólt: „Egy kis kávét öntöttem a padlóra. Föl tudná törölni?"

Mondott bárki valami olyat, amit nem kellett volna, vagy valami olyat, ami nem volt odaillő?

Ha igen:

Ki mondott olyat, amit nem kellett volna, vagy valami olyat, ami nem volt odaillő?

Mért nem kellett volna neki ezt mondania, vagy miért volt ez nem odaillö?

Mit gondol, miért mondta ezt?

Tudta vajon Tamás, hogy Feri egy másik vendég volt?

Mit gondol, hogy érezhette magát Feri?

Kontrollkérdések:

A történetben mért állt Feri a pénztár mellett?

Mit löttyentett ki Tamás? 
17. Rita a buszmegállóban várt. A busz késett, és ő már hosszú ideje ott állt. 65 éves volt, és lefárasztotta, hogy sokat kellett ott állnia. Mikor végül a busz megérkezett, zsúfolt volt és nem maradt ülőhely. Meglátta egyik szomszédját, Pált, aki a busz ülések közötti folyosóján állt. „Helló, Rita”mondta „Sokáig vártál odalent?” „Körülbelül 20 percet” - válaszolt. Egy fiatalember, aki ült, felállt. „Asszonyom, leül a helyemre?"

Mondott bárki valami olyat, amit nem kellett volna, vagy valami olyat, ami nem volt odaillő?

Ha igen:

Ki mondott olyat, amit nem kellett volna, vagy valami olyat, ami nem volt odaillő?

Mért nem kellett volna neki ezt mondania, vagy miért volt ez nem odaillő?

Mit gondol, miért mondta ezt?

Amikor Rita felszállt a buszra, vajon Pál tudta, hogy mennyi ideig várt?

Mit gondol, hogyan érezhetett Rita?

Kontrollkérdések:

A történetben mért várt Rita 20 percet a buszmegállóban?

Volt szabad hely a buszon, amikor felszállt?

18. Balázs most kezdett el új munkahelyén, egy irodában dolgozni. Egy napon a kávézóban egyik új barátjával, Andrással beszélgetett. „Mit dolgozik a feleséged?” - kérdezte András. „Ö ügyvéd” válaszolta Balázs. Néhány perccel később Klára jött be a kávézóba, idegesnek tűnt. „Most kaptam egy rossz telefonhívást” - mondta nekik. „Az ügyvédek mind olyan arrogánsak és kapzsik. Ki nem állhatom őket.” „Van kedved átnézni a jelentéseket?” - kérdezte András Klárától. „Most nem. Meg kell innom a kávémat.”

Mondott bárki valami olyat, amit nem kellett volna, vagy valami olyat, ami nem volt odaillő?

Ha igen:

Ki mondott olyat, amit nem kellett volna, vagy valami olyat, ami nem volt odaillő?

Mért nem kellett volna neki ezt mondania, vagy miért volt ez nem odaillö?

Mit gondol, miért mondta ezt?

Tudta Klára, hogy Balázs felesége ügyvéd?

Mit gondol, hogyan érezhette magát Balázs?

Kontrollkérdések:

A történet szerint mit dolgozott Balázs felesége?

Hol találkozott András és Balázs? 
19. Richárd új autót vett, egy piros Peugeot-t. Néhány héttel azután, miután megvette, beletolatott szomszédja, Zsolt autójába, egy ütött-kopott Volvóba. Az új autó egyáltalán nem sérült meg, és nem csinált nagy kárt Zsolt autójában sem, csak a kerék felett egy karcolást a festésben. Ennek ellenére átment és bekopogott az ajtón. Amikor Zsolt kinyitotta, Richárd azt mondta: „Nagyon sajnálom. Épp most ejtettem egy kis karcolást a kocsidon.” Zsolt ránézett, majd azt mondta: „Ne aggódj miatta. Csak egy kis baleset volt."

Mondott bárki valami olyat, amit nem kellett volna, vagy valami olyat, ami nem volt odaillö?

Ha igen:

Ki mondott olyat, amit nem kellett volna, vagy valami olyat, ami nem volt odaillö?

Mért nem kellett volna neki ezt mondania, vagy miért volt ez nem odaillő?

Mit gondol, miért mondta ezt?

Tudta Richárd, hogy szomszédja, Zsolt reakciója milyen lesz?

Mit gondol, hogy érezhette magát Zsolt?

Kontrollkérdések:

A történetben mit tett Richárd Zsolt kocsijával?

Hogyan reagált Zsolt?

20. Lujza elment a henteshez, hogy vásároljon egy kis húst. Zsúfolt és zajos volt a bolt. Megkérdezte a hentest, hogy „Van friss csirkéje?. Ö bólintott és elkezdett csomagolni egy grillcsirkét neki. „Elnézést” - szólt „Nem beszéltem érthetően. Azt kérdeztem, van-e nyers csirkéje.” „Ó, sajnálom!” - mondta a hentes. „Kifogytunk belöle.”

Mondott bárki valami olyat, amit nem kellett volna, vagy valami olyat, ami nem volt odaillő?

Ha igen:

Ki mondott olyat, amit nem kellett volna, vagy valami olyat, ami nem volt odaillő?

Mért nem kellett volna neki ezt mondania, vagy miért volt ez nem odaillő?

Mit gondol, miért mondta ezt?

Amikor elkezdte becsomagolni a csirkét Lujzának, tudta vajon a hentes, hogy ö sült csirkét akart?

Mit gondol, hogyan érezhette magát Lujza?

Kontrollkérdések:

A történetben hova ment Lujza?

Miért kezdett el a hentes egy sült csirkét becsomagolni neki? 


\section{Hallási mondatterjedelem Teszt}

\begin{tabular}{|c|c|c|c|}
\hline Mondatok I. Sorozat & $\mathbf{I} / \mathbf{H}$ & $+/-$ & Megjegyzés \\
\hline $\begin{array}{l}\text { 1. Egy iskolás gyerek táskájában sok a füzet. } \\
\text { 2. A négylábú madarak közé tartozik a veréb. }\end{array}$ & $\begin{array}{l}\mathrm{I} \\
\mathrm{H}\end{array}$ & & \\
\hline $\begin{array}{l}\text { 1. A legtöbb nőnél van az utcán táska. } \\
\text { 2. Az érett banánt nagyon szereti a majom. } \\
\text { 3. A házak tetején mindig van pince. }\end{array}$ & $\begin{array}{l}\mathrm{I} \\
\mathrm{I} \\
\mathrm{H}\end{array}$ & & \\
\hline $\begin{array}{l}\text { 1. A varrónő által gyakran használt eszköz az olló. } \\
\text { 2. Az egyik leglassabb állat a világon a csiga. } \\
\text { 3. A madarak csőrében mindig sok a kávé. } \\
\text { 4. A könyvtárban sok a kölcsönözhető ruha. }\end{array}$ & $\begin{array}{l}\mathrm{I} \\
\mathrm{I} \\
\mathrm{H} \\
\mathrm{H}\end{array}$ & & \\
\hline $\begin{array}{l}\text { 1. Húsvétkor ritkán fogyasztott étel a tojás. } \\
\text { 2. Lakott területeken elterjedt rágcsáló az egér. } \\
\text { 3. Az erős széltőll könnyen felborulhat a csónak. } \\
\text { 4. A szoba kifestéséhez mindig kell szoknya. } \\
\text { 5. Az emeletes házakban általában van lépcsö. }\end{array}$ & $\begin{array}{l}\mathrm{H} \\
\mathrm{I} \\
\mathrm{I} \\
\mathrm{H} \\
\mathrm{I}\end{array}$ & & \\
\hline $\begin{array}{l}\text { 1. A szemét tárolására alkalmas tárgy a kuka. } \\
\text { 2. A meleg tea sokak által kedvelt ital. } \\
\text { 3. Hazánk erdőiben megtalálható a növényevő tigris. } \\
\text { 4. A fújós hangszerek közé tartozik a villa. } \\
\text { 5. Télen a hideg ellen elkél egy kabát. } \\
\text { 6. Minden iskolás táskájában van függöny. }\end{array}$ & $\begin{array}{l}\mathrm{I} \\
\mathrm{I} \\
\mathrm{H} \\
\mathrm{H} \\
\mathrm{I} \\
\mathrm{H}\end{array}$ & & \\
\hline $\begin{array}{l}\text { 1. Télen sok ember lábán van csizma. } \\
\text { 2. A hús felszelésére alkalmas eszköz a kanál. } \\
\text { 3. Falkában élő ragadozó állat a farkas. } \\
\text { 4. Minden szilveszterkor jellegzetes ital a pezsgő } \\
\text { 5. Lila színü minden érett alma. } \\
\text { 6. A legtöbb híd oldalán van korlát. } \\
\text { 7. Minden ember kedvenc hangszere a gitár. }\end{array}$ & $\begin{array}{l}\text { I } \\
\mathrm{H} \\
\mathrm{I} \\
\mathrm{I} \\
\mathrm{H} \\
\mathrm{I} \\
\mathrm{H}\end{array}$ & & \\
\hline $\begin{array}{l}\text { 1. Sokféle gyümölcs termöhelye a csörgedezö patak. } \\
\text { 2. A legtöbbet használt természetes édesítő a cukor. } \\
\text { 3. A mogyorós csoki egy nagyon veszélyes fegyver. } \\
\text { 4. Régen fából készült minden szekrény. } \\
\text { 5. Vízben élö ebihalból fejlödik ki a béka. } \\
\text { 6. A déli sarkvidéken található minden fenyő. } \\
\text { 7. A spagetti elkészítéséhez általában kell tészta. } \\
\text { 8. A tavasz első hírnöke a fehér kecske. }\end{array}$ & $\begin{array}{l}\mathrm{H} \\
\mathrm{I} \\
\mathrm{H} \\
\mathrm{I} \\
\mathrm{I} \\
\mathrm{H} \\
\mathrm{I} \\
\mathrm{H}\end{array}$ & & \\
\hline
\end{tabular}

\begin{tabular}{|l|l|l|l|}
\hline Mondatok II. Sorozat & I / H & + / - & Megjegyzés \\
\hline 1. Két lábon jár minden kígyó. & $\mathrm{H}$ & & \\
2. A gyerekek egyik kedvenc játéka a labda. & $\mathrm{I}$ & & \\
\hline 1. Nagy károkat képes okozni a vihar. & $\mathrm{I}$ & & \\
2. A kopasz emberek haját vágja le a fodrász. & $\mathrm{H}$ & & \\
3. A bokron termő málnát szereti a medve. & $\mathrm{I}$ & & \\
\hline 1. Az állatok királya a mesékben a hangya. & $\mathrm{H}$ & & \\
2. Könnyen eltörhet a kemény felületre leejtett pohár. & $\mathrm{I}$ & & \\
3. Az alma egy föld alatt termő gyümölcs. & $\mathrm{H}$ & & \\
\hline
\end{tabular}




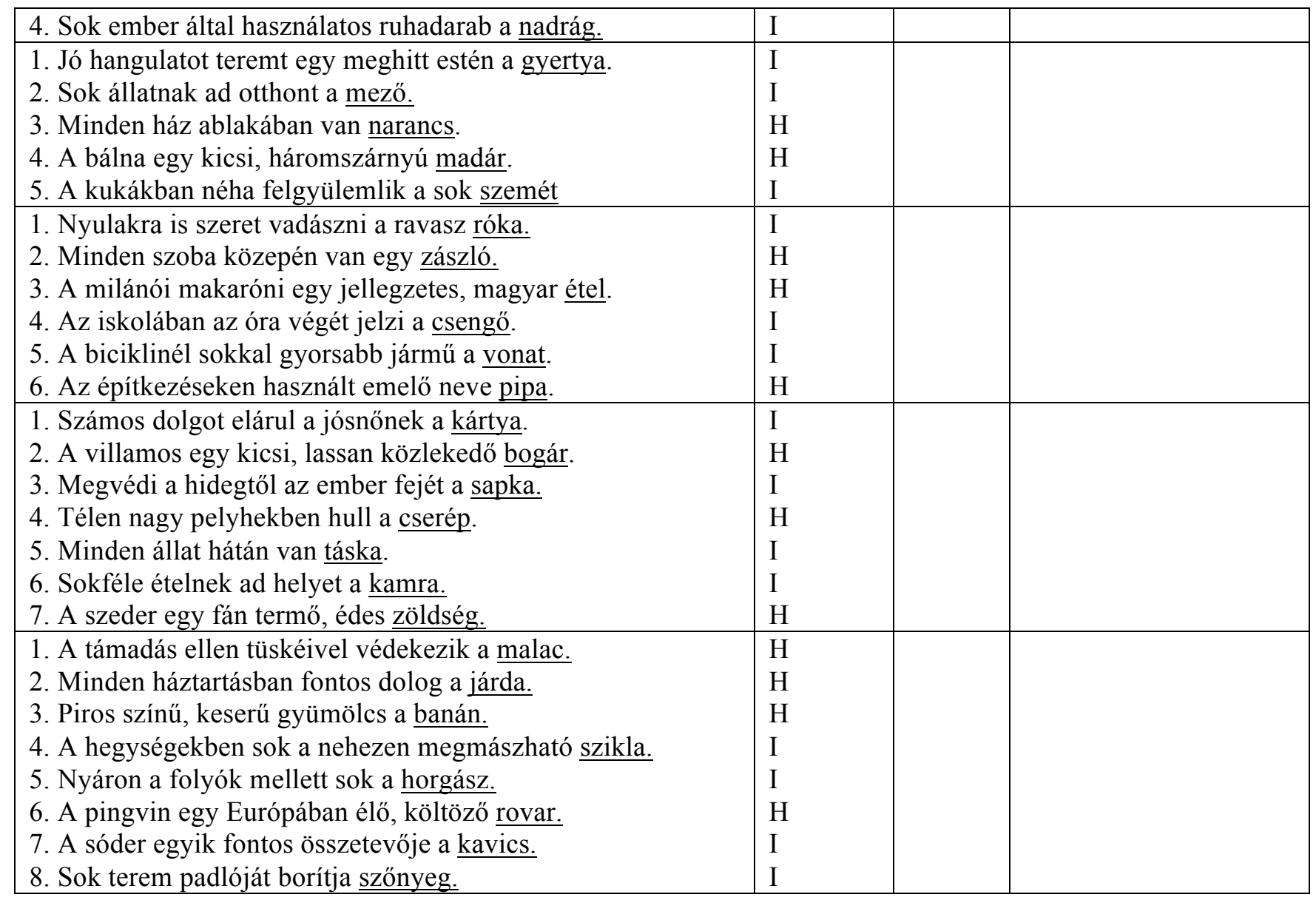

\begin{tabular}{|c|c|c|c|}
\hline Mondatok III. Sorozat & $\mathbf{I} / \mathbf{H}$ & $+/-$ & Megjegyzés \\
\hline $\begin{array}{l}\text { 1. A gyerekek egyik kedvenc édessége a torta. } \\
\text { 2. A házak tetején télen füstöl a kémény. }\end{array}$ & $\begin{array}{l}\text { I } \\
\text { I }\end{array}$ & & \\
\hline $\begin{array}{l}\text { 1. Tízlábú, vízben élö állat a bika. } \\
\text { 2. Könnyen eltörhet a porcelánból készült tányér. } \\
\text { 3. Eső elött általában sok az égen a felhö. }\end{array}$ & $\begin{array}{l}\mathrm{H} \\
\mathrm{I} \\
\mathrm{I}\end{array}$ & & \\
\hline $\begin{array}{l}\text { 1. Fán termő, keserü növény a hagyma. } \\
\text { 2. Minden folyó mélyén van egy torony. } \\
\text { 3. Védelmet adhat sok állatnak a barlang. } \\
\text { 4. A kicsi egér nagy ellensége a macska. }\end{array}$ & $\begin{array}{l}\mathrm{H} \\
\mathrm{H} \\
\mathrm{I} \\
\mathrm{I}\end{array}$ & & \\
\hline $\begin{array}{l}\text { 1. Sok embert szórakoztat esténként a tévé. } \\
\text { 2. Tengerekben élö, okos állat a kakas. } \\
\text { 3. A hegyekben az olvadó hótól megárad a folyó. } \\
\text { 4. Takarításnál gyakran használt eszköz a csésze. } \\
\text { 5. A pékségben készül a finom, meleg kenyér. }\end{array}$ & $\begin{array}{l}\mathrm{I} \\
\mathrm{H} \\
\mathrm{I} \\
\mathrm{H} \\
\mathrm{I}\end{array}$ & & \\
\hline $\begin{array}{l}\text { 1. A liliom egy csúnya, rovarokkal táplálkozó virág. } \\
\text { 2. A legyet hálójában ejti foglyul a mókus. } \\
\text { 3. A mai fürdöszobák többségében van tükör. } \\
\text { 4. Hideg téli estéken befüti a lakást a kályha. } \\
\text { 5. A kislányok haját gyakran díszíti szalag. } \\
\text { 6. A tehenek kedvenc étele a fött sonka. }\end{array}$ & $\begin{array}{l}\mathrm{H} \\
\mathrm{H} \\
\mathrm{I} \\
\mathrm{I} \\
\mathrm{I} \\
\mathrm{H}\end{array}$ & & \\
\hline $\begin{array}{l}\text { 1. Megfázáskor jó a toroknak a hideg beton } \\
\text { 2. Egy ma is élö, kistermetü állat a patkány. }\end{array}$ & $\begin{array}{l}\mathrm{H} \\
\mathrm{I}\end{array}$ & & \\
\hline
\end{tabular}


3. Sokféle holmi tárolására alkalmas tárgy a doboz.

4. A macskák kedvenc étele a friss borsó.

5. Sok lakásban ég esténként a lámpa.

6. A sivatagokban nagy dünéket alkot a homok.

7. Kistermetü rágcsáló a mezökön ugrándozó tehén.

1. A kertes házakhoz általában tartozik udvar.

2. Méhek által gyüjtött nektárból készül a leves.

3. Sok beteget ápol a kórházban a nővér.

4. Az osztriga tengerekben élő, ehető kagyló.

5. Üvegből készül minden női cipő.

6. A hazánk északi részén áthaladó Rajna egy hegység.

7. A legtöbb városban van legalább egy kocsma.

8. A Mars egy emberek által lakott bolygó.

ÖSSZESEN (a három sorozat átlaga):

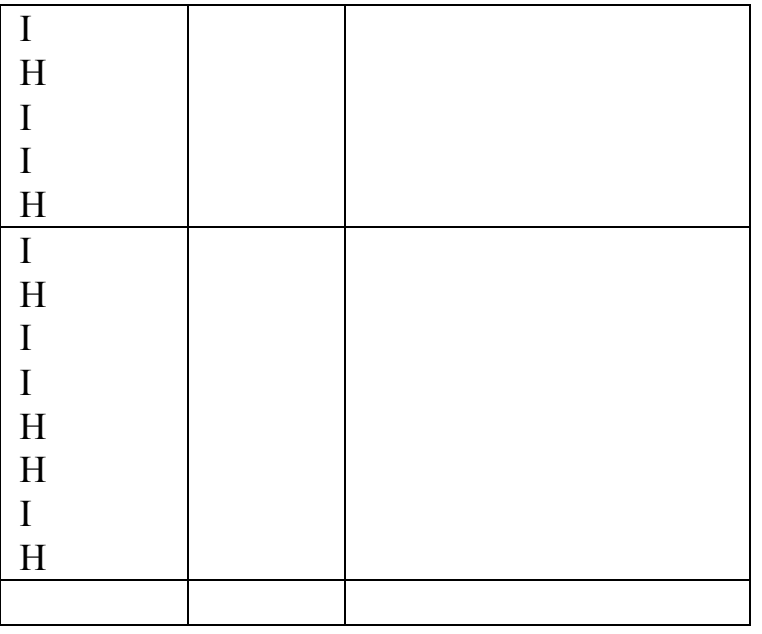


Számterjedelem teszt

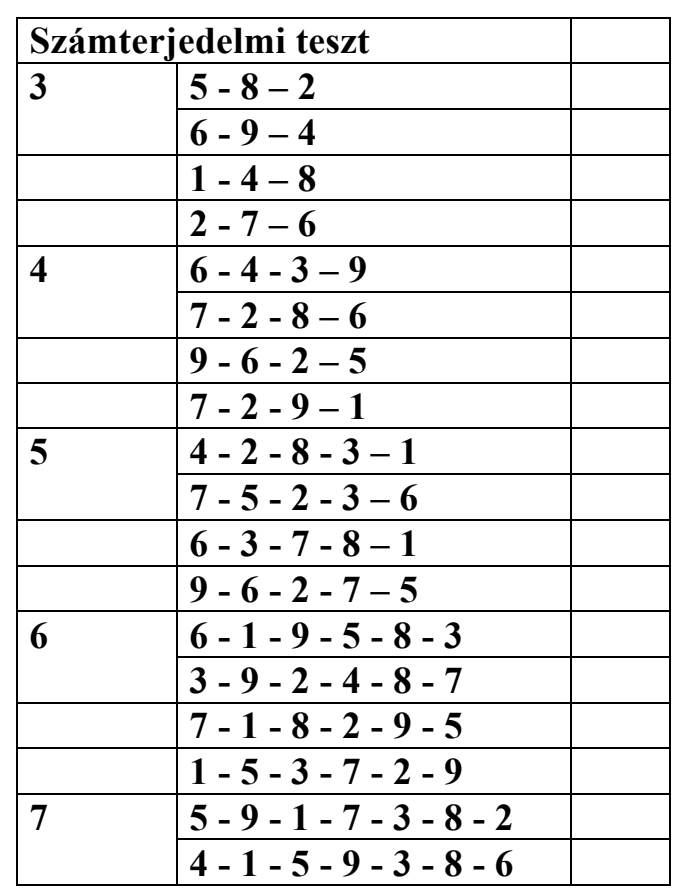

\begin{tabular}{|l|l|l|}
\hline & $6-5-1-4-3-9-2$ & \\
\hline & $1-4-2-5-3-8-6$ & \\
\hline & $5-8-1-9-2-6-4-$ & \\
& 3 & \\
\hline & $3-7-2-9-5-1-8-$ & \\
& 6 & \\
\hline & $5-9-1-6-8-3-4-$ & \\
& 2 & \\
\hline \multirow{5}{*}{9} & $3-2-5-7-6-9-1-$ & \\
& 8 & \\
& $2-7-5-8-6-3-9-$ & \\
& $1-4$ & \\
\hline & $7-1-3-9-4-2-5-$ & \\
& $6-8$ & \\
\hline & $8-1-4-9-6-2-5-$ & \\
& $7-3$ & \\
\hline & $2-9-5-1-7-3-4-$ & \\
& $6-8$ & \\
\hline
\end{tabular}

Számterjedelem:

\section{Fordított számterjedelem}

\begin{tabular}{|c|c|c|}
\hline \multicolumn{3}{|c|}{ Fordított számterjedelem } \\
\hline \multirow[t]{4}{*}{3} & $1-8-4$ & \\
\hline & $7-8-1$ & \\
\hline & $9-7-1$ & \\
\hline & $2-5-9$ & \\
\hline \multirow[t]{4}{*}{4} & $6-2-3-8$ & \\
\hline & $7-9-8-6$ & \\
\hline & $1-6-2-5$ & \\
\hline & $9-4-2-1$ & \\
\hline \multirow[t]{4}{*}{5} & $6-5-7-3-2$ & \\
\hline & $3-5-9-4-8$ & \\
\hline & $6-2-7-3-1$ & \\
\hline & $5-6-3-9-4$ & \\
\hline \multirow[t]{4}{*}{6} & $6-1-8-4-5-3$ & \\
\hline & $3-9-2-4-8-7$ & \\
\hline & $7-1-8-3-9-5$ & \\
\hline & $2-7-5-4-2-1$ & \\
\hline \multirow[t]{4}{*}{7} & $9-5-7-1-2-6-8$ & \\
\hline & $1-4-9-7-8-3-6$ & \\
\hline & $5-6-3-1-9-4-2$ & \\
\hline & $7-4-1-8-3-5-6$ & \\
\hline
\end{tabular}

\begin{tabular}{|c|c|}
\hline 8 & $8-5-9-1-2-4-6-7$ \\
\hline & $2-7-3-9-8-1-5-4$ \\
\hline & $1-9-5-3-8-6-4-2$ \\
\hline & $3-2-7-5-4-1-9-8$ \\
\hline 9 & $\begin{array}{l}8-7-5-2-9-2-6-4 \\
-1\end{array}$ \\
\hline & $\begin{array}{l}3-1-7-9-5-2-4-8 \\
-6\end{array}$ \\
\hline & $\begin{array}{l}3-1-8-5-6-2-9-7 \\
-4\end{array}$ \\
\hline & $\begin{array}{l}2-9-1-5-3-7-4-6 \\
-8\end{array}$ \\
\hline
\end{tabular}


Számlálási terjedelem teszt

Gyakorlás

a) 3

\section{SOROZAT}

$\begin{array}{r}5 \\ -7 \\ -5 \\ 4 \\ \hline\end{array}$
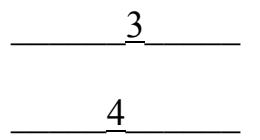

2

$\underline{2}$

8

2. SOROZAT

$\begin{array}{r}4 \\ -7 \\ \hline 3 \\ \hline 4 \\ \hline 7\end{array}$

2
3

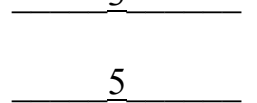

6

4

\section{SOROZAT}
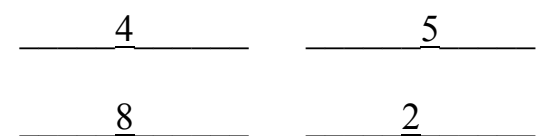

$\underline{3}$

$\frac{3}{2}$
$\frac{8}{2}$

$\begin{array}{r}\frac{7}{6} \\ 5 \\ \hline\end{array}$

b)

2

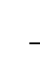

7

c)

$4-6$

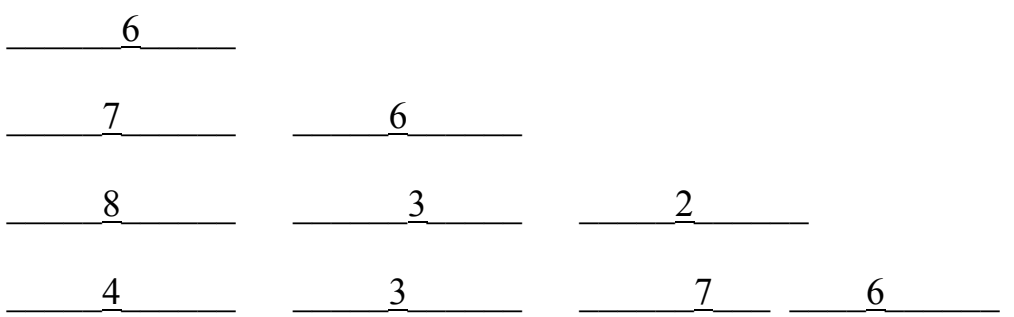

Terjedelem (a három sorozat átlaga):

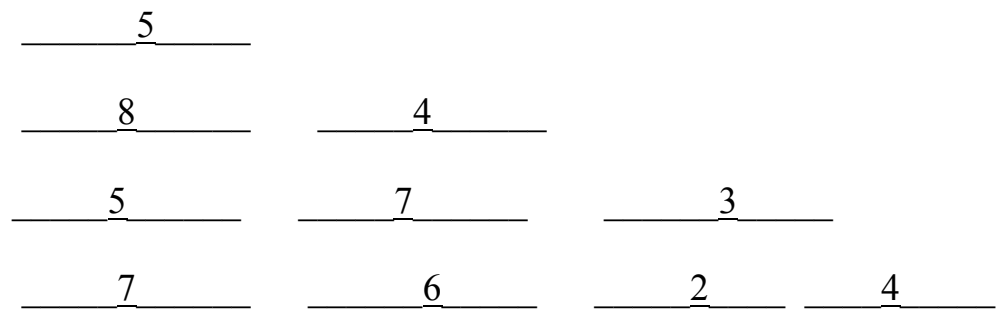

\section{Egyszerü választásos szociometria}

Sorold fel 3 osztálytársadat, akivel szívesen töltenél együtt több időt! 1.

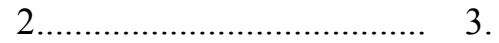

Sorold fel 3 osztálytársadat, akivel a legkevésbé töltenél együtt több időt! 1. 